PAulo HenRiQue Raiol Ostia

\title{
DESENHO DE SISTEMA DE SOLUÇÃO DE CONFLITO: SISTEMAS INDENIZATÓRIOS EM INTERESSES INDIVIDUAIS HOMOGÊNEOS
}

DisSERTAÇÃO DE MESTRADO

Orientadora: Professora Doutora Susana Henriques Da CoSta

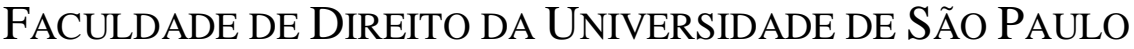

Departamento de Direito Processual

SÃo PAULO

2014 
Paulo Henrique Raiol Ostia

\section{DESENHO DE SISTEMA DE SOLUÇÃO DE CONFLITO: SISTEMAS INDENIZATÓRIOS EM INTERESSES INDIVIDUAIS HOMOGÊNEOS}

Dissertação de Mestrado apresentada ao Departamento de Direito Processual da Faculdade de Direito da Universidade de São Paulo, sob a orientação da Profa. Dra. Susana Henriques da Costa, como requisito para a obtenção do título de mestre.

FACUldade de Direito da Universidade de São PaUlo Departamento de Direito Processual

SÃo PAULO

2014 


\section{RESUMO}

Por mais que os cientistas separem e classifiquem os elementos da realidade para melhor compreendê-la, ele preserva a sua natureza complexa e multidisciplinar.

O mesmo raciocínio pode ser aplicado aos conflitos.

A sociedade de massa, por sua vez, potencializou o surgimento de conflitos complexos. As peculiaridades e os diferentes aspectos destas situações tornam improvável que sejam adequadamente tratados e solucionados por mecanismos genéricos.

Considerando isso e em uma perspectiva de meios adequados de solução de conflito, o método do desenho de sistemas de solução de conflito (Dispute System Design DSD) propõe que sejam criados sistemas personalizados a partir de princípios e técnicas. Dessa forma, seriam dadas as respostas processuais aos diferentes aspectos do conflito.

Com o intuito de analisar a aplicação dos princípios e técnicas do DSD à realidade, estudar-se-ão os casos da Câmara de Indenização Voo 3054 (CI3054) e do Programa de Indenização Voo 447 (PI447). Estes sistemas tinham como escopo solucionar os conflitos provenientes de acidentes aéreos que ocorreram em 2007 e 2009, com aeronaves das companhias TAM e Air France, respectivamente. Nas duas tragédias não houve sobreviventes.

Palavras-chave: desenho de sistema de solução de conflito; meios adequados; meios consensuais; negociação, conciliação; mediação; interesses individuais homogêneos; consumidor; acidentes aéreos. 


\section{Abstract}

Although the scientists separate and classify the elements of reality to understand it better, it preserves its complex and multidisciplinary nature.

The same reasoning can be applied to conflicts.

The mass society, in its turn, increased the emergence of complex conflicts. The peculiarity and the different aspects of these situations makes it unlikely to be adequately processed and solved by generic mechanisms.

Considering this and the perspective of adequate conflict resolution, the Dispute System Design - DSD suggests that custom systems can be created from principles and technical. Therefore would be given the procedural responses to the different aspects of the conflict.

In order to examine the application of the principles and techniques of DSD to reality, will be studied the cases of the Câmara de Indenização Voo 3054 (CI3054) and Programa de Indenização Voo 447 (PI447). These systems were scoped to resolve conflicts arising from plane crashes that occurred in 2007 and 2009, with TAM and Air France aircraft. In the two tragedies there were no survivors.

Key-words: dispute system design; adequate dispute resolution; negotiation; mediation; class action; consumer; plane crash. 
SUMÁRIO

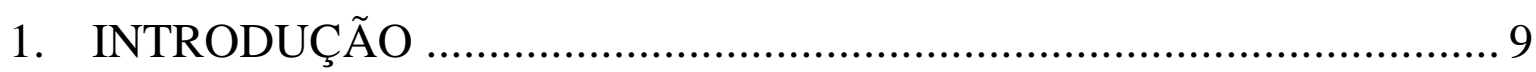

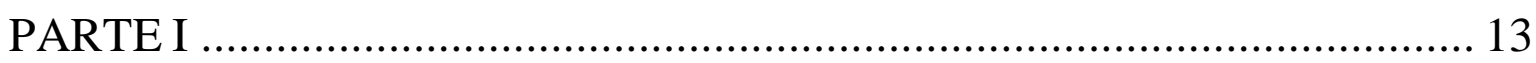

2. SOCIEDADE DE MASSA E SEUS CONFLITOS................................. 13

2.1. INTERESSES INDIVIDUAIS HOMOGÊNEOS ………………………........ 19

2.1.1. RESPONSABILIDADE CIVIL E INTERESSES INDIVIDUAIS HOMOGÊNEOS DOS CONSUMIDORES …………………………………..... 23

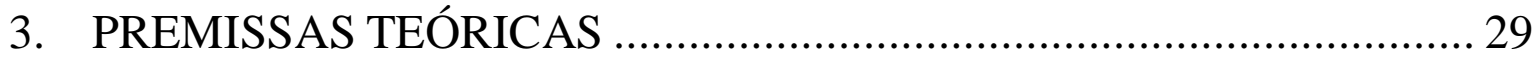

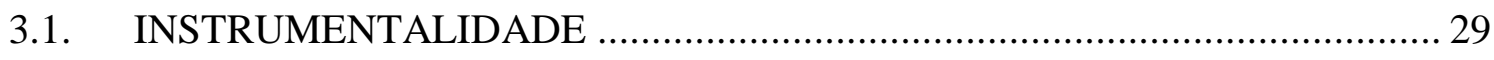

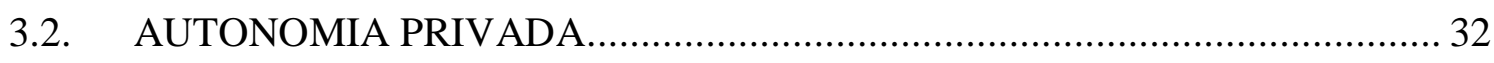

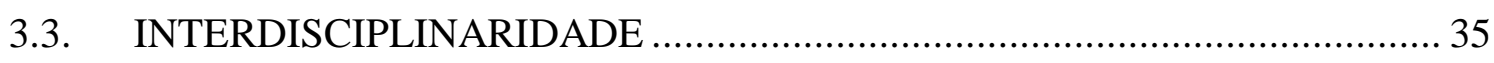

3.4. INTERESSE, REGRA E PODER: BASES DA SOLUÇÃO DE CONFLITOS 37

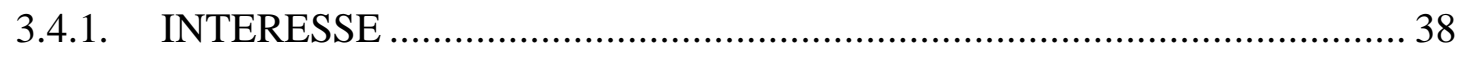

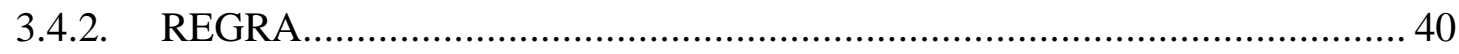

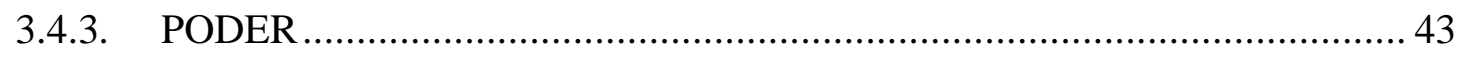

3.4.4. INTERESSE, REGRA E PODER: INTER-RELAÇÃO........................... 45

3.5. PLURALIDADE DE MECANISMOS DE SOLUÇÃO DE CONFLITO ......... 48

3.5.1. MEIOS ADEQUADOS DE SOLUÇÃO DE CONFLITO .......................... 51

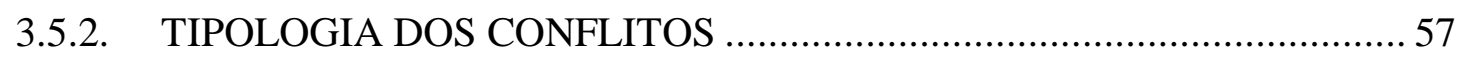

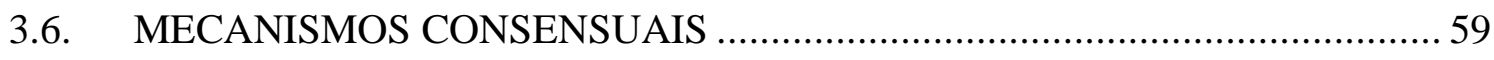

3.6.1. RACIONALIDADE DOS MECANISMOS CONSENSUAIS ................... 61

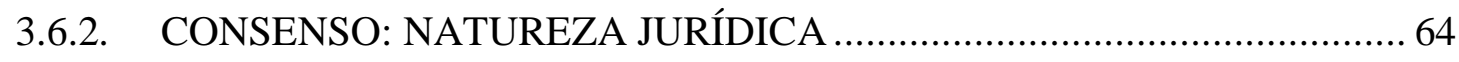

3.6.3. CARACTERÍSTICAS DOS MECANISMOS CONSENSUAIS .................69

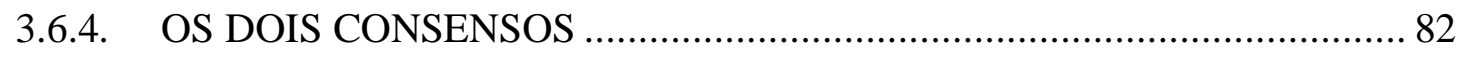

3.6.5. O PROBLEMA DA EFETIVIDADE DOS MECANISMOS

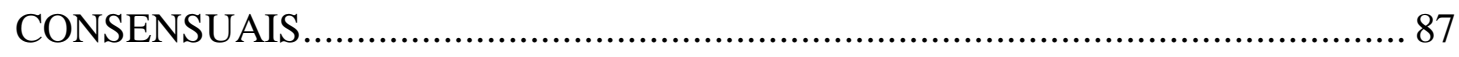


4. DSD - DISPUTE SYSTEM DESIGN

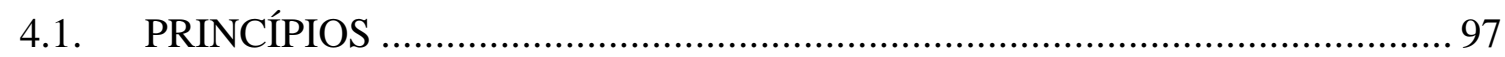

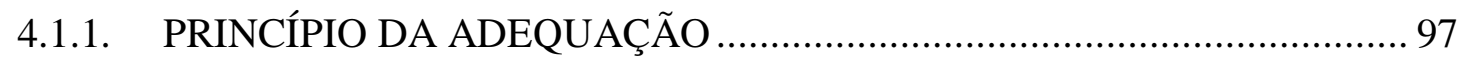

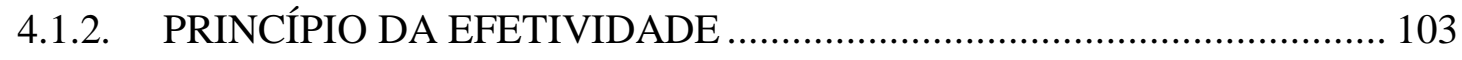

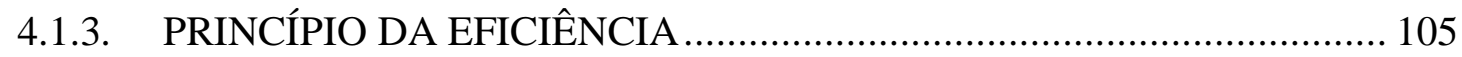

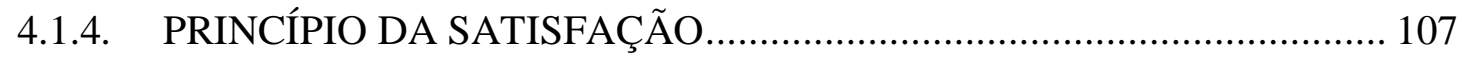

4.1.5. PRINCÍPIO DO DSD - URY, BRETT, GOLDBERG ………………....... 108

4.2. CUSTOS DO TRATAMENTO DO CONFLITO (COSTS OF DISPUTING) . 111

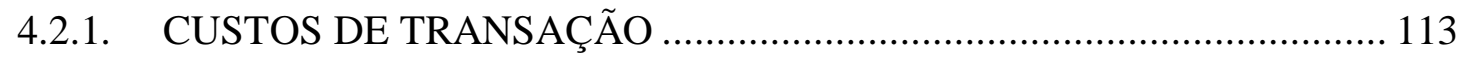

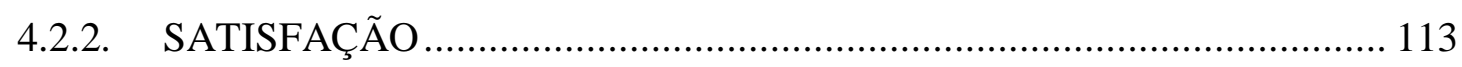

4.2.3. EFEITOS DO MECANISMO E DE SEU RESULTADO NA RELAÇÃO

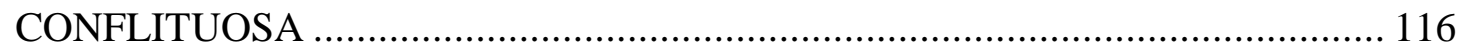

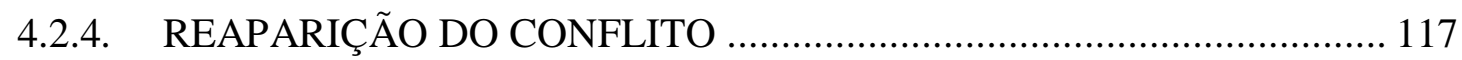

4.2.5. CUSTO: INTERESSE, REGRA, PODER …………….......................... 118

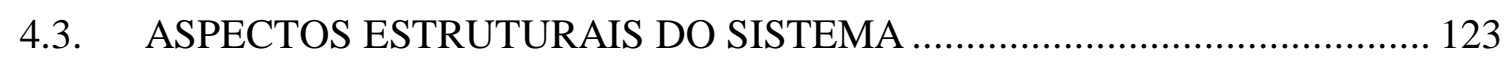

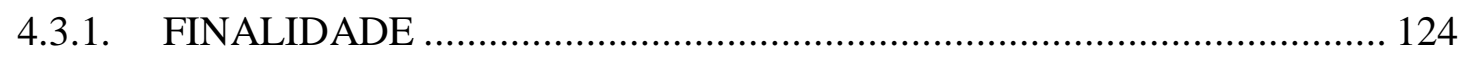

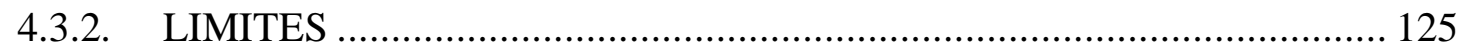

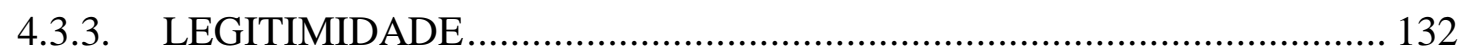

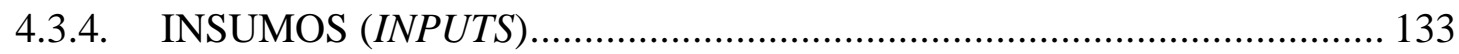

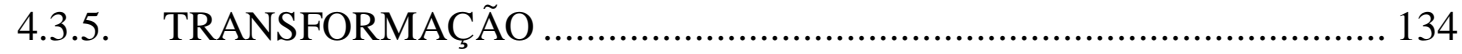

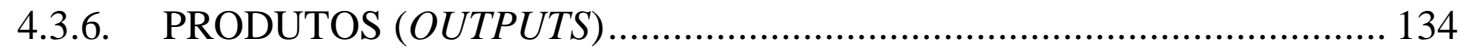

4.3.7. AVALIAÇÃO DO SISTEMA (FEEDBACK) .......................................... 136

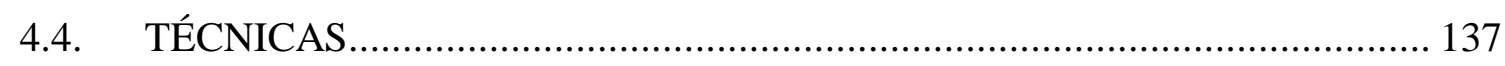

4.4.1. CONSIDERAR OS INTERESSES (PUT THE FOCUS ON INTERESTS) 138

4.4.2. CONSTRUÇÃO DE RETORNOS À VIAS CONSENSUAIS (BUILD IN

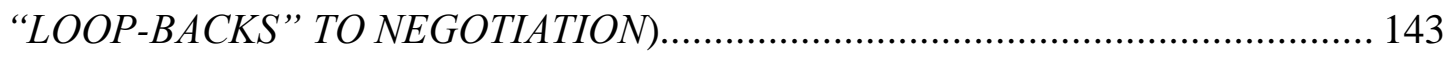

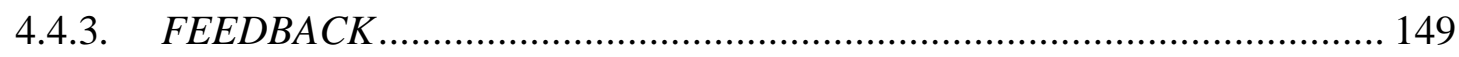


4.4.4. RECURSOS: MOTIVAÇÃO, HABILIDADES

4.4.5. PARÂMETROS REFERENCIAIS.............................................................. 152

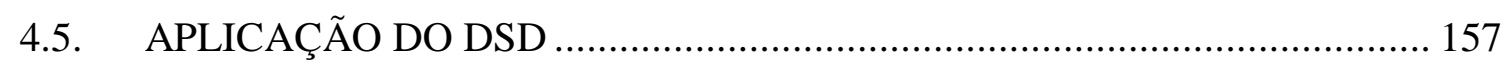

4.5.1. QUEM SÃO OS ATORES (PLAYERS)?………...................................... 158

4.5.2. DIAGNÓSTICOS DOS SISTEMAS EXISTENTES …………………......... 164

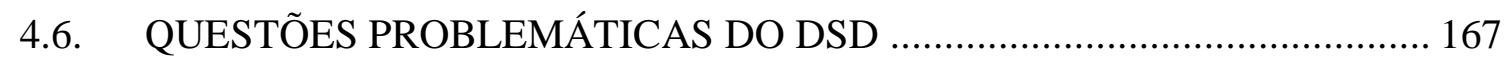

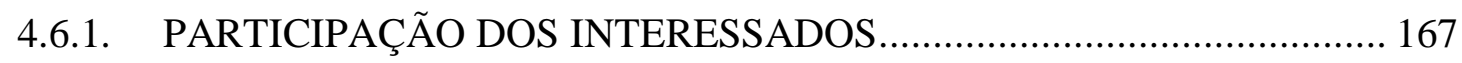

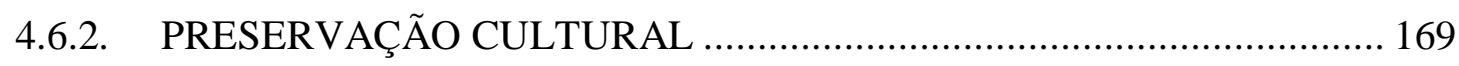

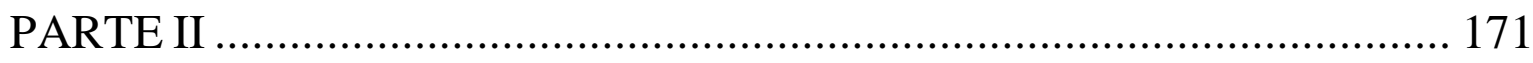

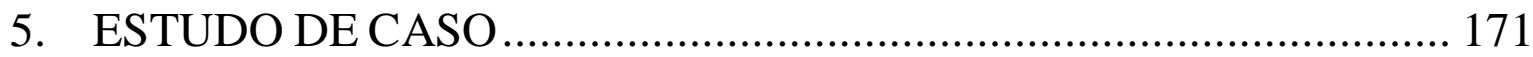

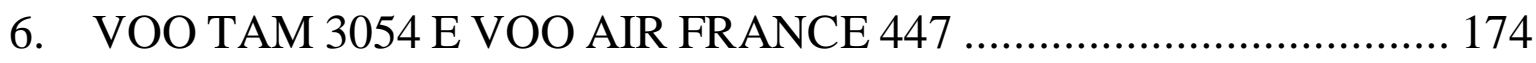

6.1. DESCRIÇÃO FÁTICA DOS ACIDENTES................................................. 174

6.2. CÂMARA DE INDENIZAÇÃO VOO 3054 (CI3054) E PROGRAMA DE

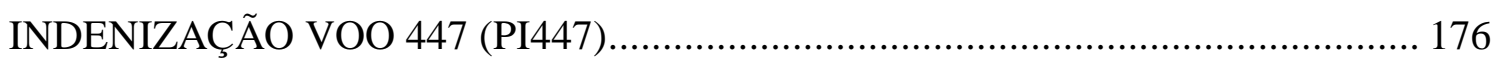

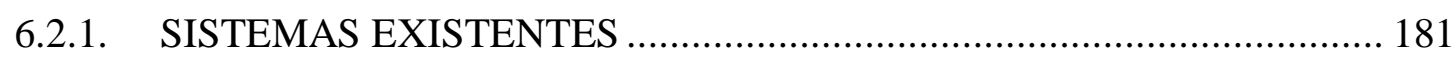

6.2.2. ASPECTOS DO CONFLITO E SUAS RESPOSTAS ............................... 184

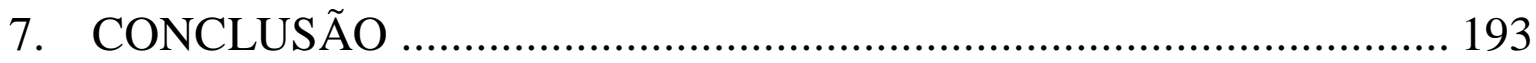

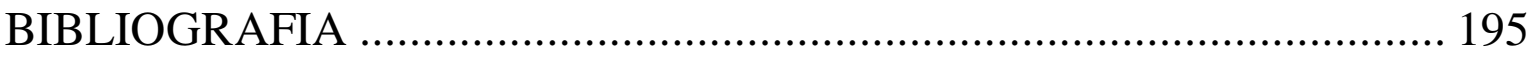




\section{INTRODUÇÃO}

Independentemente da forma que se dá o desenvolvimento humano, seja linear ou pendular, observam-se, em um mesmo contexto histórico, movimentos antagônicos. Ao mesmo tempo em que há a massificação da sociedade e de seus grupos com seus interesses homogêneos e transindividuais, há também a busca pela preservação da diferença, com o reforço da individualidade e da pluralidade.

Frente a essa complexidade e à diversidade do ser humano, de suas necessidades, de suas relações e de seus problemas, torna-se improvável que sistemas que não observam esta multiplicidade consigam atender adequada e efetivamente às demandas individuais e sociais. ${ }^{1}$

Considerando estes aspectos, propõe-se uma reflexão quanto aos conflitos humanos e aos seus meios de solução. ${ }^{2}$

Há uma grande variedade de tipos de conflitos interpessoais, cada qual com suas características e especificidades. ${ }^{3}$ Contudo, dificilmente estas peculiaridades serão consideradas de modo satisfatório por modelos massificados de solução de conflito. Eles são idealizados genericamente exatamente para abranger um maior número de situações. ${ }^{4}$

\footnotetext{
1 "Vivemos em época de transformação. Os antigos institutos jurídicos não mais conseguem resolver, de forma eficaz e satisfatória, as novas demandas sociais e jurídicas. O processo, como forma civilizada de solução do conflito dos interesses qualificados pela pretensão resistida, em seu modelo tradicional, mostravase, cada vez mais, desajustado às novas exigências sociais. A doutrina processual erigida para a tutela de direitos individuais não mais era suficiente, nem adequada, para atender aos novos reclamos de setores significativos da sociedade". PINHO, Rodrigo César Rebello. Apresentação. In Processo civil e interesse público: o processo como instrumento de defesa social. Org. SALLES, Carlos Alberto de. São Paulo: Editora Revista dos Tribunais, 2003, p. 11.

2 O escopo principal do processo é a pacificação com justiça. Dessa forma, também é função do processualista a busca e a criação de vias apropriadas para que se alcance este escopo. CINTRA, Antonio Carlos de Araújo; GRINOVER, Ada Pellegrini; DINAMARCO, Cândido Rangel. Teoria Geral do Processo. $22^{\mathrm{a}}$ Ed. São Paulo: Malheiros Editores, 2006, p. 30. DINAMARCO, Cândido Rangel. Instituições de direito processual civil. Vol. I. 5a Ed. São Paulo: Malheiros Editores, 2005, p. 146.

${ }^{3}$ Conforme tópico TIPOLOGIA DOS CONFLITOS, p. 57.

4 "once we appreciate that an encounter or injury may be crystallized into very different kinds of disputes and may be handled in very different kinds of institutions, we recognize that sorting disputes by their suitability to particular dispute processes is not a technical exercise but a political choice of which kinds of disputes deserve which kinds of response, which in turn reflects our commitments about the good society and the good life". GALANTER, Marc. Compared to what? Assessing the quality of dispute processing. In: Denver University Law Review, n. 66, 1988-1989, p. XIV.
} 
A princípio, quanto maior o grau de especificidade e complexidade do conflito, maior será a inadequação do mecanismo padronizado.

Com este entendimento, põe-se em dúvida se o mecanismo adjudicatório estatal $^{5}$ seria sempre o meio adequado e efetivo para tratar e solucionar conflitos.

Destaca-se, desde logo, que este estudo não busca, aprioristicamente, desqualificar ou enaltecerá os meios judiciais ou quaisquer outros. Isto porque, baseia-se na premissa de que todos os mecanismos de solução de conflito têm a potencialidade de ser adequados ou inadequados, a depender da situação conflituosa ao qual será aplicado. Serão as características do conflito e as necessidades das partes por ele afetadas que determinarão qual é o instrumento mais adequado para processá-lo e solucioná-lo.

Qualquer posicionamento absoluto, que indicasse este ou aquele como sendo sempre o instrumento mais adequado, estaria desconsiderando a multiplicidade e complexidade social e, dessa forma, tenderia ao erro.

Busca-se com este estudo propor uma nova perspectiva na solução de conflitos. Mais do que simplesmente utilizar as ferramentas existentes, aponta-se a possibilidade de criar um mecanismo específico, visando assim atender, da melhor forma possível, toda e qualquer peculiaridade de uma determinada situação conflituosa. Originar-se-ia, dessa forma, o sistema mais adequado para o tratamento do conflito para o qual foi desenhado.

Este desenho ${ }^{6}$ do instrumento adequado é especialmente desafiador, visto que as variantes são muitas. Mesmo assim, é imprescindível que todos os aspectos sejam considerados, justamente para que sejam respeitadas as peculiaridades e, desse modo, se alcance uma resposta adequada e efetiva ao conflito.

Essa nova perspectiva proposta para a solução dos conflitos encontra base principiológica e técnica no "Desenho de Sistema de Solução de Disputa" (DSD - Dispute

\footnotetext{
${ }^{5}$ Por mais que existam exceções, o mecanismo adjudicatório estatal é predominantemente padronizado.

${ }^{6}$ Ressalta-se que, no contexto da presente análise, a ação de desenhar ou criar não está ligada a condutas meramente engenhosas, artísticas e inventivas, que se dão de forma aleatória, mas sim, principalmente, referem-se a ações controladas que, por meio do gerenciamento de elementos, dão forma ao produto que se pretende.
} 
System Design), ${ }^{7}$ objeto do presente estudo. O DSD é um método, ${ }^{8}$ ou seja, um conjunto de etapas para atingir um fim. Dentro do ideário do DSD, este escopo é criação do mecanismo adequado para tratar um determinado conflito ou os conflitos provenientes de uma determinada relação. ${ }^{9}$

Optou-se, todavia, por restringir o objeto deste estudo apenas ao desenho de sistemas de solução de conflito consensuais. Estes apresentam racionalidade própria, ${ }^{10}$ culminando, entre outros aspectos, em dinâmicas, técnicas e benefícios diversos de mecanismos que tenham como base elemento diverso do consenso.

Não se pode esquecer, todavia, que a sociedade atual é predominantemente de massa. O mencionado movimento de massificação, pelo qual a sociedade passou e, em alguma medida, continua passando, deu origem a valores, interesses e relações massificadas, repetindo-se em toda sociedade ou em seus grupos. Invariavelmente, os titulares destes interesses ou os sujeitos destas relações enfrentariam situações de insatisfação, dando origem a conflitos igualmente massificados. Esta característica de homogeneidade, contudo, não afasta a possibilidade de essas situações conflituosas apresentarem peculiaridades e complexidades e necessitarem do instrumento adequado para o seu tratamento.

Tendo isto em vista, será estudada a criação e a aplicação de sistemas consensuais personalizados, criados a partir dos princípios e técnicas do DSD, a conflitos decorrentes de violações a interesses individuais homogêneos.

Quanto à estrutura, este trabalho foi idealizado com duas partes. Na primeira, têm-se como objetivo apresentar o respaldo teórico para os direitos individuais homogêneos, para os meios consensuais de solução de conflito, bem como os princípios e técnicas do DSD.

\footnotetext{
${ }^{7}$ Conforme URY, William L.; BRETT, Jeanne M.; GOLDBERG, Stephen B. Getting disputes resolved: designing systems to cut the cost of conflict. $1^{\mathrm{a}}$ Ed. São Francisco: Jossey-Bass Publishers, 1988, p. 1.

8 "Método, em geral, é um conjunto de processos de que utilizamos para atingir um fim. Método é o caminho correto para se chegar a um fim; é a ordem adequada de procedimentos que se deve seguir e impor-se aos diferentes processos necessários à consecução de um objetivo dado”. ALVES, Alaôr Caffé. Lógica: pensamento formal e argumentação, elementos para o discurso jurídico. $4^{\mathrm{a}}$ Ed. São Paulo: Quartier Latin, 2005 , p. 298.

${ }^{9}$ Conforme FALECK, Diego. Introdução ao Design de Sistemas de Disputas: Câmara de Indenização 3054. In Revista brasileira de arbitragem, Ano V, n. 23 São Paulo: IOB, 2009, p. 9.

${ }^{10}$ Conforme será estudado no tópico RACIONALIDADE DOS MECANISMOS CONSENSUAIS, p. 61.
} 
Já na segunda parte, serão analisados dois casos de aplicação do DSD. Eles foram desenhados especificamente para o tratamento dos conflitos indenizatórios provenientes de dois acidentes aéreos, dando origem à Câmara de Indenização Voo 3054 $(\mathrm{CI} 3054)^{11}$ e ao Programa de Indenização Voo 447 (PI447). ${ }^{12}$

Com essa estruturação do trabalho, almeja-se desenvolver uma análise dedutiva $^{13}$ sobre o DSD.

Para que não fosse prejudicada a viabilidade e a qualidade deste estudo, optouse por restringir o tema da seguinte forma: serão analisadas a criação e a aplicação de sistemas de solução de conflitos personalizados com base no método do DSD, que tenham natureza consensual e tenham como escopo o tratamento adequado de conflitos indenizatórios provenientes de direito individual homogêneo consumerista.

\footnotetext{
11 A Câmara de Indenização Voo 3054 (CI3054) proporcionou uma alternativa célere e efetiva para a indenização dos beneficiários das vítimas do acidente aéreo ocorrido em 17 de julho de 2007 em São PauloSP, com uma aeronave da empresa aérea TAM que tinha decolado de Porto Alegre-RS. Sua criação é resultado da parceria entre a Defensoria Pública do Estado de São Paulo, Ministério Público do Estado de São Paulo, Fundação PROCON-SP e Ministério da Justiça, através da Secretaria de Direito Econômico, membros do Sistema Nacional de Defesa do Consumidor, previsto no Título IV, artigos 105 e seguintes do Código de Defesa do Consumidor, com a participação da Associação dos Familiares e Amigos das Vítimas do Voo TAMJJ3054 (AFAVITAM), da TAM e de suas seguradoras. O acidente foi o pior da América Latina e vitimou todos os 187 ocupantes da aeronave e ainda mais 12 pessoas em solo, totalizando 199 mortos.

12 O Programa de Indenização Voo 447 (PI447), de forma semelhante à CI3054, proporcionou uma alternativa célere e efetiva para a indenização dos beneficiários das vítimas do acidente aéreo ocorrido em 31 de maio de 2009 no Oceano Atlântico, com uma aeronave da empresa aérea Air France que fazia o trecho Rio de Janeiro - Paris. Sua criação é resultado da parceria entre o Ministério Público do Estado do Rio de Janeiro, Fundação PROCON-RJ e Ministério da Justiça, através da Secretaria de Direito Econômico, com a participação da Air France e de suas seguradoras. O acidente vitimou todos os 228 ocupantes da aeronave.

${ }^{13}$ Conforme estudos de ALVES, Alaôr Caffé. Lógica: pensamento formal e argumentação, elementos para o discurso jurídico. $4^{\text {a }}$ Ed. São Paulo: Quartier Latin, 2005, p. 261.
} 


\section{PARTE I}

\section{SOCIEDADE DE MASSA E SEUS CONFLITOS}

As necessidades e as possibilidades humanas alteram-se ao longo do tempo. Com isso, um modelo produtivo, tido como adequado, tende a mostrar-se defasado e ser gradativamente $^{14}$ superado por outro paradigma, mais apto a responder adequadamente às novas necessidades e às novas possibilidades sociais.

A produção de massa, tipo ${ }^{15}$ de organização produtiva, ${ }^{16}$ é fruto das novas tecnologias que surgiram no final do século XIX e começo do XX, ainda em um contexto econômico baseado nos mercados nacionais. Com aprimoramentos tecnológicos, como a linha de montagem criada por Henry Ford, ${ }^{17}$ maquinaria dedicada (single purpose) e o plano de produção fixo, tornou-se possível o aumento da produção de bens e de riquezas. ${ }^{18}$

Neste regime de organização produtiva, com base em peças padronizadas e trabalhadores especializados, são fabricados bens idênticos em larga escala. Mantem-se, assim, o custo de produção baixo. ${ }^{19} 20$

\footnotetext{
${ }^{14}$ Cabe esclarecer que a superação dos tipos de organização de produção não ocorre de forma absoluta, mas sim gradativamente. Isso porque, a história acontece de forma fluida. Assim, são naturais estruturas produtivas híbridas, que carregam aspectos de vários tipos de produção, como também, a existência, em um mesmo instante, de sistemas produtivos baseados em diferentes tipos produtivos, nos tipos superados, no tipo contemporâneo e, inclusive, no tipo que virá a ser o dominante. Uma breve ilustração é a produção automotiva artesanal que, apesar de ter sido sucedido por outros tipos, ainda persiste nos dias atuais.

${ }^{15}$ Emprega-se o termo "tipo" conforme a concepção de "tipo puro" ou "tipo ideal” de Max Weber. (WEBER, Max. Economy and society. Los Angeles: University of California Press, 1978, p. XXXVIII).

${ }^{16}$ Os tipos de organização produtiva são ideários aplicados à produção, especificando e caracterizando-a por determinado período de tempo. MAXIMIANO, Antonio Cesar Amaru. Teoria geral da administração: da revolução urbana à revolução digital. $3^{\text {a }}$ Ed. São Paulo: Editora Atlas, 2002, p. 163.

${ }^{17}$ Por mais que se dê a Henry Ford a autoria da linha de montagem, "desde os primórdios da Revolução Industrial, bicicletas, armas, peças, livros e jornais já eram produzidos em massa. Os venezianos [...] já dominavam a montagem seriada de navios no século XVI". Contudo, foi Henry Ford que maximizou em sua totalidade as características da produção de massa. Em 1914, com a adoção pela Ford da linha de montagem móvel e motorizada para a produção de chassis, passou-se de 12 horas e 28 minutos de trabalho, ainda sob a técnica artesanal, para 1 hora e 33 minutos. Tais avanços atraíram outras empresas a incorporar o mesmo tipo de produção. MAXIMIANO, Antonio Cesar Amaru. Teoria geral da administração: da revolução urbana à revolução digital. $3^{\text {a }}$ Ed. São Paulo: Editora Atlas, 2002, p. 163-164 e 166-167.

${ }^{18}$ Mesmo que atualmente a produção de massa possa ser vista como algo antiquado, frente às inovações que ocorrem na área produtiva, representou um grande avanço para sua época, sendo a forma de produção mais eficiente que se conhecia até então.

${ }^{19}$ Conforme MACEDO JR., Ronaldo Porto. Contratos relacionais e defesa do consumidor. $2^{\text {a }}$ Ed. São Paulo: Revista dos Tribunais, 2006, p. 95.
} 
A insigne frase de Henry Ford, "Any customer can have a car painted any colour that he wants so long as it is black", ${ }^{21}$ sintetiza os principais aspectos do fordismo ${ }^{22}$ e da produção de massa. Ela também evidência que a escolha ${ }^{23}$ ou a possibilidade de personalização do produto, não passa de uma ilusão, devido à inaptidão desse regime produtivo em lidar com a individualização.

Soma-se a essas características o fato de que o êxito deste tipo de organização produtiva está diretamente ligado ao consumo, que, por sua vez, depende do interesse e da necessidade das pessoas pelos seus produtos. Tendo estes aspectos em vista, chega-se ao entendimento que a produção de massa tem um melhor desempenho em um contexto no qual os consumidores são tão padronizados quanto os produtos a eles ofertados.

Estes bens, necessariamente iguais e produzidos em larga escala, terão maior demanda em uma sociedade massificada, homogênea, com gostos, necessidades e valores iguais. Tem-se assim a sociedade de massa. É fundamental, para tanto, a eliminação ou a desconsideração das diferenças e das especificidades que venham a existir entre os indivíduos. $^{24}$

São inúmeros consumidores adquirindo produtos iguais, produzidos em série. Isto faz com que existam diversas relações jurídicas com o mesmo objeto, por exemplo, a compra e venda de um determinado eletrodoméstico. Já quanto ao elemento subjetivo, em

${ }^{20}$ Conforme MAXIMIANO, Antonio Cesar Amaru. Teoria geral da administração: da revolução urbana à revolução digital. $3^{\text {a }}$ Ed. São Paulo: Editora Atlas, 2002, p. 164.

${ }^{21}$ FORD, Henry. My life and work. New York: Cosimo, 2007, p. 72.

${ }^{22}$ Conforme MAXIMIANO, Antonio Cesar Amaru. Teoria geral da administração: da revolução urbana à revolução digital. $3^{\text {a }}$ Ed. São Paulo: Editora Atlas, 2002, p. 163.

${ }^{23}$ Cabe esclarecer que, eventualmente, existem produtos concorrentes, fabricados por outros produtores, artesanalmente ou dentro dos parâmetros da produção de massa. Destaca-se, todavia, unicamente a impossibilidade do consumidor ter de um produtor de massa um produto com diferenças, como cor e motorização, aproveitando o exemplo do carro.

${ }^{24}$ Ilustrativamente, se todos os homens vestissem calças pretas e camisas brancas e dirigissem o mesmo modelo de carro preto, haveria uma relação otimizada entre a demanda e a oferta. Atualmente, há um embate entre padrão e diversidade, massa e singularidade, que faz com que sejam correntes produtos de massa que trazem ao consumidor a sensação de único. Um mesmo modelo de casaco de moletom, simples, é produzido com 20 possibilidades de cores, estampas e padronagens. Este último exemplo tem como base a marca de roupa japonesa Uniqlo. Fundada há 28 anos pelo atual homem mais rico do Japão, Tadashi Yanai, tem lojas em regiões estratégicas, voltadas às marcas de alta costura, e planeja abrir 300 lojas por ano e se tornar a maior rede que vende roupas da própria marca no mundo. Baseando no conceito cheap-chic, busca equilibrar produtos de baixo custo devido à sua produção e massa com qualidade e diversidade. Disponível em http://g1.globo.com/globo-news/noticia/2012/04/rede-de-lojas-japonesa-ganha-o-mundo-vendendo-roupascom-o-conceito-barato-chique.html e http://g1.globo.com/bom-dia-brasil/noticia/2012/03/inauguracao-damaior-loja-do-mundo-da-uniqlo-atrai-multidao-em-toquio.html. 
um lado, estes diversos vínculos convergem no fornecedor do bem, que se torna um polo irradiador de relações jurídicas homogêneas, no outro lado, há uma grande pulverização de sujeitos, os consumidores.

Por mais que concretamente sejam liames distintos, ${ }^{25}$ em abstrato, são relações jurídicas comuns a estes sujeitos. Isto faz com que, ainda que individuais, esses diversos vínculos possam ser considerados conjuntamente. ${ }^{26}$ Surgem, de forma análoga aos bens produzidos em escala, relações em escala, como os contratos de adesão. ${ }^{27}$ Com esta nova modalidade, eventuais vícios em produtos ou serviços, assim como cláusulas contratuais abusivas têm o condão de atingir indevidamente a esfera de interesse ${ }^{28}$ de um grande número de consumidores.

Desse modo, os conflitos passam a ter uma nova configuração, polarizando-se entre um conjunto de indivíduos que tiveram seus direitos lesados de forma homogênea e, do outro lado, o agente responsável por esta lesão.

Dentro de uma perspectiva de acesso à Justiça, ${ }^{29}$ há a necessidade de garantir a esses interesses, quando atacados, não apenas o acesso ao judiciário, como também à "tutela jurisdicional adequada e efetiva à situação de direito material lesada ou ameaçada de lesão". 30

O reconhecimento e a tutela destes interesses individuais homogêneos e dos transindividuais trouxeram novos desafios para os juristas.

\footnotetext{
25 Ainda que o objeto e um dos sujeitos da relação repitam-se nas diversas relações, em concreto e individualmente, no outro polo figurará o consumidor $\mathrm{X}, \mathrm{Y}$ ou $\mathrm{Z}$.

${ }^{26}$ Os requisitos para o tratamento a título coletivo dos interesses individuais homogêneos será analisado no próximo tópico INTERESSES INDIVIDUAIS HOMOGÊNEOS, p. 19.

${ }^{27}$ Os contratos de adesão são, resumidamente, contratos padrão, nos quais apenas uma das partes estipula suas cláusulas, cabendo à outra apenas aceitá-las ou não, ou seja, aderir ou não, sem a possibilidade de negociá-las. Conforme GOMES, Orlando. Contratos. 26ª Ed. Rio de Janeiro: Editora Forense, 2008, p. 128.

${ }^{28}$ A expressão "esfera de interesses" será mais bem tratada no tópico INTERESSE, p. 38.

${ }^{29}$ Conforme a segunda e terceira ondas de acesso à justiça indicadas por Mauro Cappelletti e Bryant Garth. CAPPELLETTI, Mauro; GARTH, Bryant. Acesso à justiça. Tradução Ellen Gracie Northfleet. Porto Alegre: Sergio Antonio Fabris Editor, 2002, p. 49 e 67.

${ }^{30}$ COSTA, Susana Henriques da. A tutela do patrimônio público e da moralidade administrativa por meio da ação civil publica e da ação de improbidade administrativa. In MAZZEI, Rodrigo; NOLASCO, Rita Dias. Processo civil coletivo. $1^{\text {a }}$ Ed. São Paulo: Quartier Latin, 2005, p. 567.
} 
Entre esses, existe a questão da excessiva diluição das lesões. ${ }^{31}$ Em muitos casos, os danos individualmente considerados não são relevantes o bastante para fazer com que seus titulares tenham interesse em enfrentar os custos e buscar a devida tutela. Ainda que tenham os recursos financeiros, eventualmente não terão o suporte técnico para lograr êxito frente ao causador do dano, muitas vezes um litigante habitual, ${ }^{32}$ experiente e preparado para a batalha judicial. ${ }^{33}$

Ademais, devido à pulverização de titulares, encontravam-se dificuldades tanto para a reunião deles e de suas demandas, como para que fosse estabelecido um representante da pluralidade de sujeitos que tivesse condições de defender adequadamente tais interesses. Contudo, ainda que se conseguisse definir um representante, persistiam questões quanto ao direito de contraditório dos representados, assim como quanto aos efeitos da coisa julgada a estes indivíduos que não participaram diretamente do processo.

O ordenamento nacional definiu, em um conjunto de leis, como o Código de Defesa do Consumidor (CDC) e a Lei de Ação Civil Pública, respostas para estas questões, como a modulação da coisa julgada quando da tutela coletiva ${ }^{34}$ e o regime de substituição

\footnotetext{
31 “O problema básico que eles [direitos 'difusos'] apresentam - a razão de sua natureza difusa - é que, ou ninguém tem direito de corrigir a lesão a um interesse coletivo, ou o prêmio para qualquer indivíduo buscar essa correção é pequeno demais para induzi-lo a tentar uma ação". CAPPELLETTI, Mauro; GARTH, Bryant. Acesso à justiça. Tradução Ellen Gracie Northfleet. Porto Alegre: Sergio Antonio Fabris Editor, 2002, p. 26. Este não é o caso dos danos decorrentes de acidentes aéreos que serão estudados, VOO TAM 3054 E VOO AIR FRANCE 447, p. 177, já que compõem danos significativos, decorrente de falecimento e de considerável quantia.

${ }^{32}$ Conforme CAPPELLETTI, Mauro; GARTH, Bryant. Acesso à justiça. Tradução Ellen Gracie Northfleet. Porto Alegre: Sergio Antonio Fabris Editor, 2002, p. 25.

33 Conforme LEONEL, Ricardo de Barros. Manual do processo coletivo. São Paulo: Editora Revista dos tribunais, 2002, p. 110.

${ }^{34}$ Conforme artigo 103 do Código de Defesa do Consumidor: "Art. 103. Nas ações coletivas de que trata este código, a sentença fará coisa julgada: I - erga omnes, exceto se o pedido for julgado improcedente por insuficiência de provas, hipótese em que qualquer legitimado poderá intentar outra ação, com idêntico fundamento valendo-se de nova prova, na hipótese do inciso I do parágrafo único do art. 81; II - ultra partes, mas limitadamente ao grupo, categoria ou classe, salvo improcedência por insuficiência de provas, nos termos do inciso anterior, quando se tratar da hipótese prevista no inciso II do parágrafo único do art. 81; III erga omnes, apenas no caso de procedência do pedido, para beneficiar todas as vítimas e seus sucessores, na hipótese do inciso III do parágrafo único do art. 81 . $§ 1^{\circ}$ Os efeitos da coisa julgada previstos nos incisos I e II não prejudicarão interesses e direitos individuais dos integrantes da coletividade, do grupo, categoria ou classe. $\S 2^{\circ} \mathrm{Na}$ hipótese prevista no inciso III, em caso de improcedência do pedido, os interessados que não tiverem intervindo no processo como litisconsortes poderão propor ação de indenização a título individual. § $3^{\circ}$ Os efeitos da coisa julgada de que cuida o art. 16, combinado com o art. 13 da Lei $n^{\circ} 7.347$, de 24 de julho de 1985, não prejudicarão as ações de indenização por danos pessoalmente sofridos, propostas individualmente ou na forma prevista neste código, mas, se procedente o pedido, beneficiarão as vítimas e seus sucessores, que poderão proceder à liquidação e à execução, nos termos dos arts. 96 a 99. $§ 4^{\circ}$ Aplica-se o disposto no parágrafo anterior à sentença penal condenatória".
} 
processual. ${ }^{35}$ Quanto a este último, o CDC estabelece não só um rol de legitimados ativos para a tutela coletiva dos interesses dos consumidores, ${ }^{36}$ como também o Sistema Nacional de Defesa do Consumidor (SNDC), ${ }^{37}$ que está entre os participantes dos casos analisados. ${ }^{38}$

Como será tratado ao longo deste estudo, algumas destas disposições são válidas para o tratamento de conflitos que tenham origem na violação de interesses individuais homogêneos por meio de sistemas de solução de conflito consensuais desenhados à luz do ideário do DSD. Como exemplo, pode-se apontar a substituição dos titulares por legítimos representantes para consentir com o desenho e com a adoção de um mecanismo personalizado para dirimir conflitos indenizatórios decorrentes de relações de consumo. $^{39}$

Por fim, cabem algumas ressalvas quanto ao estudo da sociedade de massa. Não se defende que ela seja indispensável para a produção de massa, nem que esta seja condição para aquela, nem que haja uma necessária relação de causa e efeito entre elas, mas sim, que há afinidade eletiva ${ }^{40}$ entre esses dois fenômenos que permite a existência de uma relação favorável para ambos. Isso significa que, entre a sociedade de massa e a produção de massa, ocorre uma interação facultativa, não necessária, que, por gerar benefícios para as duas, favorece a subsistência delas. Isso se dá devido à existência, nestes dois fenômenos, de características que funcionam melhor quando juntas.

\footnotetext{
${ }^{35}$ Conforme artigo $6^{\circ}$ do Código de Processo Civil: "Art. $6^{\circ}$. Ninguém poderá pleitear, em nome próprio, direito alheio, salvo quando autorizado por lei".

${ }^{36}$ Conforme artigo 82 do Código de Defesa do Consumidor: "Para os fins do art. 81, parágrafo único, são legitimados concorrentemente: I - o Ministério Público; II - a União, os Estados, os Municípios e o Distrito Federal; III - as entidades e órgãos da Administração Pública, direta ou indireta, ainda que sem personalidade jurídica, especificamente destinados à defesa dos interesses e direitos protegidos por este código; IV - as associações legalmente constituídas há pelo menos um ano e que incluam entre seus fins institucionais a defesa dos interesses e direitos protegidos por este código, dispensada a autorização assemblear. $\S 1^{\circ} \mathrm{O}$ requisito da pré-constituição pode ser dispensado pelo juiz, nas ações previstas nos arts. 91 e seguintes, quando haja manifesto interesse social evidenciado pela dimensão ou característica do dano, ou pela relevância do bem jurídico a ser protegido".

${ }^{37}$ Conforme artigo 105 do Código de Defesa do Consumidor: "Art. 105. Integram o Sistema Nacional de Defesa do Consumidor (SNDC), os órgãos federais, estaduais, do Distrito Federal e municipais e as entidades privadas de defesa do consumidor".

${ }^{38}$ VOO TAM 3054 E VOO AIR FRANCE 447, p. 177

${ }^{39}$ Como será analisado no tópico OS DOIS CONSENSOS, p. 83.

${ }^{40}$ Conforme WEBER, Max. Economy and society. Los Angeles: University of California Press, 1978, p. 341. Como ilustração à afinidade eletiva, tem-se o estudo de Max Weber, que afirma a existência deste tipo de relação entre o capitalismo e o protestantismo. Esse fenômeno é semelhante às relações biológicas harmônicas de protocooperação, relação facultativa que gera benefícios para cada parte da relação. AMABIS, José Mariano; MARTHO, Gilberto Rodrigues. Fundamentos da biologia moderna. $2^{\text {a }}$ Ed. São Paulo: Editora Moderna, 1997, p. 38.
} 
Além disso, por mais que considerar a sociedade como uma grande massa homogênea facilite seu estudo, isto não corresponde à realidade. Observa-se que a sociedade atual é extremamente complexa. Não há um grande grupo absolutamente homogêneo, mas sim diversos grupos de indivíduos reunidos a partir de suas características e de seus interesses comuns. É o que ocorre, por exemplo, com os grupos dos idosos, dos ambientalistas, dos agraristas, dos religiosos, dos homossexuais, dos consumidores de serviços de telecomunicação, dos consumidores dos serviços de plano de saúde. Como facilmente se extrai dos exemplos, há alta probabilidade de que um mesmo indivíduo componha mais de um conjunto. Tem-se, desse modo, uma grande pluralidade e diversidade de grupos homogêneos.

Quando do estudo das coletividades e dos indivíduos, deve-se tomar cuidado com a perspectiva adotada. Isso porque, o indivíduo não está isolado, ele compõe uma coletividade, que o influencia e que por ele é influenciada. Contudo, ainda assim, mantêm sua individualidade.

Desse modo, a homogeneidade e a diversidade, por mais que se contraponham, coexistem na mesma realidade. Uma preponderará sobre a outra a depender da perspectiva que se adote sobre o objeto analisado. ${ }^{41}$

O tratamento de conflitos individuais homogêneos por meio de vias consensuais balanceia estes dois elementos: a coletividade e o indivíduo. Isto porque, como ainda será analisado, estes mecanismos comportam duas etapas, tratando o conflito coletiva e individualmente. ${ }^{42}$

41 "This assumption, that there are only two sides of a case, limits the usefulness of adjudication in many modem cases in which there are more than two sides, especially in modem litigation with interventions, class actions, interpleaders, and more than one issue to be determined". MEADOW, Carrie Menkel. Mothers and Fathers of Invention: The Intellectual Founders of ADR. Ohio: Ohio State Journal on Dispute Resolution, 2000, p. 21.

${ }^{42}$ Conforme será estudado no tópico OS DOIS CONSENSOS, p. 83. 


\subsection{INTERESSES INDIVIDUAIS HOMOGÊNEOS}

O direito ${ }^{43}$ individual homogêneo, como se depreende da sua própria denominação, é direito subjetivo individual, com perfeita identificação e individualização de seu titular. Contudo, liga-se a outros devido à origem comum e à homogeneidade. ${ }^{44}$ Estas duas características permitem que esses interesses possam ser tutelados a título coletivo, conforme introduzido pelo Código de Defesa do Consumidor. ${ }^{45}$

Ressalta-se, todavia, que a origem comum e a homogeneidade nem sempre caminham juntas. É possível que direitos, apesar da mesma origem, não sejam homogêneos. Dessa forma, estes dois requisitos para a tutela coletiva dos interesses individuais homogêneos não se confundem. ${ }^{46}$

${ }^{43} \mathrm{O}$ ordenamento brasileiro faz uso de dois termos: "interesse" e "direito" individual homogêneo. O artigo 129, inciso III, da Constituição emprega apenas o termo "interesse": "para a proteção do patrimônio público e social, do meio ambiente e de outros interesses difusos e coletivos"; enquanto o inciso V do mesmo artigo utiliza-os cumulativamente: "defender judicialmente os direitos e interesses das populações indígenas". $\mathrm{O}$ Código de Defesa do Consumidor, em seu artigo 81, inciso III, utiliza os dois termos, "interesses ou direitos individuais homogêneos, assim entendidos os decorrentes de origem comum", conceituando os interesses individuais homogêneos de forma ampla, para evitar que questões terminológicas sejam obstáculo para o devido acesso à justiça e à adequada tutela. No mesmo sentido, entende Ricardo de Barros Leonel: "Cumpre ao estudioso do processo, para conferir efetividade à sua ciência, modificar os termos em que a operação lógica foi tradicionalmente concebida, pois tornando à deia clássica decorrente do imanentismo, o direito reconhecia 'direitos' para só posteriormente conferir-lhes tutela. Necessário seria, de forma inversa, reconhecer que o direito deve reconhecer a possibilidade de tutela a situações da vida que devam merecer sua atenção, dentro das exigências do contexto social, e independentemente da delimitação em trilhos rígidos e em modalidade pré-concebidas, que são insuficientes para fazer frente à dinâmica da existência social. Pouco importa o nome que se dê ao remédio, mas sim o efeito que ele venha a produzir, servindo a seu fim de curar os males para os quais foi criado". LEONEL, Ricardo de Barros. Manual do processo coletivo. São Paulo: Editora Revista dos tribunais, 2002, p. 88.

44 "Direitos individuais homogêneos são [...] simplesmente direitos subjetivos individuais, divisíveis e integrados ao patrimônio de titulares certos, que sobre eles exercem, com exclusividade, o poder de disposição". ZAVASCKI, Teori Albino. Defesa de direitos coletivos e defesa coletiva de direitos. In Revista de processo, n. 78, abril-junho de 1995, ano 20, p. 34 e 37. No mesmo sentido: GRINOVER, Ada Pellegrini. Da class action for damages à ação de classe brasileira: os requisitos de admissibilidade. In MILARÉ, Édis (coordenador). Ação civil pública: lei 7.347/1985 - 15 anos. $2^{\mathrm{a}}$ Ed. São Paulo: Editora Revista dos Tribunais, 2002, p. 19. O Código de Defesa do Consumidor traz o conceito dos direitos individuais homogêneos no artigo 81, parágrafo único, inciso III: "interesses ou direitos individuais homogêneos, assim entendidos os decorrentes de origem comum". Já a lei de mandado de segurança conceitua-os no seu artigo 21, parágrafo único, inciso II: "individuais homogêneos, assim entendidos, para efeito desta Lei, os decorrentes de origem comum e da atividade ou situação específica da totalidade ou de parte dos associados ou membros do impetrante".

45 “o Código de Proteção e Defesa do Consumidor (Lei 8.078, de 11.9.90), que, entre outras novidades, introduziu mecanismo de defesa coletiva para 'direitos individuais homogêneos"'. ZAVASCKI, Teori Albino. Defesa de direitos coletivos e defesa coletiva de direitos. In Revista de processo, n. 78, abril-junho de 1995, ano 20, p. 32.

46 “Talvez a própria redação do dispositivo legal [, o Código de Defesa do Consumidor,] induza a pensar que a 'homogeneidade pela origem comum' seja um único requisito. [...] Parece evidente, no entanto, que a origem comum - sobretudo se for remota - pode não ser suficiente para caracterizar a homogeneidade". 
A origem comum, que pode ser jurídica ou fática, é a causa do direito, podendo ser um único fato, como um acidente aéreo, ou uma pluralidade de atos ou mesmo uma atividade que se prolongam no tempo, como a comercialização de remédios sem princípio ativo ou a divulgação de propagandas enganosas. ${ }^{47}$ Desse modo, a origem comum pode ser classificada como remota ou imediata, sendo que a origem comum imediata garante maior grau de homogeneidade aos direitos que a remota. ${ }^{48}$

A homogeneidade, por sua vez, é a similaridade dos direitos e decorre das circunstancias comuns ou semelhantes. Não existe, por exemplo, homogeneidade entre situações nas quais elementos pessoais tenham atuado de forma completamente diversa. ${ }^{49}$

Tendo como ilustração os casos que serão analisados, observa-se que um acidente aéreo é uma origem comum imediata, que garante alto grau de homogeneidade aos direitos indenizatórios provenientes da tragédia.

Por ser possível a perfeita identificação e individualização de seus titulares, os interesses individuais homogêneos distinguem-se dos direitos difusos ou coletivos stricto sensu. Isso porque, estes têm natureza transindividual, com titularidade absolutamente indeterminada, se difusos, ou relativamente indeterminada, se coletivos stricto sensu. ${ }^{50}$

GRINOVER, Ada Pellegrini. Da class action for damages à ação de classe brasileira: os requisitos de admissibilidade. In MILARÉ, Édis (coordenador). Ação civil pública: lei 7.347/1985 - 15 anos. $2^{\text {a }}$ Ed. São Paulo: Editora Revista dos Tribunais, 2002, p. 31.

${ }^{47}$ Conforme LEONEL, Ricardo de Barros. Manual do processo coletivo. São Paulo: Editora Revista dos tribunais, 2002, p. 109.

48 "A origem comum pode ser de fato ou de direito e, como observou Kazuo Watanabe, a expressão 'não significa, necessariamente, uma unidade factual e temporal. As vítimas de uma publicidade enganosa veiculada por vários órgãos de imprensa e em repetidos dias de um produto nocivo à saúde adquiridos por vários consumidores num largo espaço de tempo e em várias regiões têm, como causa de seus danos, fatos de uma homogeneidade tal que os tornam a 'origem comum' de todos eles". "Próxima, ou imediata, como no caso da queda de um avião, que vitimou diversas pessoas; remota, ou mediata, como no caso de um dano à saúde, imputado a um produto potencialmente nocivo, que pode ter tido como causa próxima as condições pessoais ou o uso inadequado do produto". GRINOVER, Ada Pellegrini. Da class action for damages à ação de classe brasileira: os requisitos de admissibilidade. In MILARÉ, Édis (coordenador). Ação civil pública: lei 7.347/1985 - 15 anos. $2^{\mathrm{a}}$ Ed. São Paulo: Editora Revista dos Tribunais, 2002, p. 31.

${ }^{49}$ Conforme GRINOVER, Ada Pellegrini. Da class action for damages à ação de classe brasileira: os requisitos de admissibilidade. In MILARÉ, Édis (coordenador). Ação civil pública: lei 7.347/1985 - 15 anos. $2^{\mathrm{a}}$ Ed. São Paulo: Editora Revista dos Tribunais, 2002, p. 31.

50 "é preciso que não se confunda defesa de direitos coletivos (e difusos) com defesa coletiva de direitos (individuais). Direito coletivo é direito transindividual (= sem titular determinado) e indivisível. Pode ser difuso ou coletivo stricto sensu. Já direitos individuais homogêneos são, na verdade, simplesmente direitos subjetivos individuais. A qualificação de homogêneos não desvirtua essa sua natureza, mas simplesmente os relaciona a outros direitos individuais assemelhados, permitindo a defesa coletiva de todos eles". 
Apesar disso, os interesses individuais homogêneos extrapolam o âmbito estritamente individual, aproximando-se, assim como os difusos e coletivos stricto sensu, do interesse público. ${ }^{51}$ Tanto que o ordenamento jurídico reconhece a eles tutela especial. Isso significa que, "embora [os interesses individuais homogêneos] não sejam 'coletivos' na essência, tais interesses o são formalmente ou acidentalmente para fins de tratamento processual". 52

A tutela coletiva, aplicável a todos as três espécies de direitos e interesses coletivos lato sensu, visa resguardar uma resposta célere e eficiente, assim como a coerência sistêmica, afastando decisões contraditórias. ${ }^{53}$

Além de a titularidade ser passível de identificação, o objeto dos direitos individuais homogêneos é divisível, o que possibilita que estes direitos sejam atingidos, lesados, tutelados ou satisfeitos, de modo individualizado. Diferentemente do objeto dos transindividuais, que só admite tais hipóteses de forma coletiva, devido à sua indivisibilidade. Logo, por serem divisíveis e assim integrarem o patrimônio de seus titulares, eventuais indenizações provenientes de direitos individuais homogêneos destinam-se, em regra, ${ }^{54}$ diretamente aos lesados, ${ }^{55}$ assim como podem ser objeto de transação. ${ }^{56}$

ZAVASCKI, Teori Albino. Defesa de direitos coletivos e defesa coletiva de direitos. In Revista de processo, n. 78, abril-junho de 1995, ano 20, p. 33.

51 "São interesses que excedem o âmbito estritamente individual, mas não chegam propriamente a constituir interesse público". MAZZILLI, Hugo Nigro. A defesa dos interesses difusos em juízo. 25ª Ed. São Paulo: Editora Saraiva, 2012, p. 50.

${ }^{52}$ LEONEL, Ricardo de Barros. Manual do processo coletivo. São Paulo: Editora Revista dos tribunais, 2002, p. 108.

${ }^{53}$ Conforme MAZZILLI, Hugo Nigro. A defesa dos interesses difusos em juízo. 25ª Ed. São Paulo: Editora Saraiva, 2012, p. 51.

${ }^{54}$ Caso os titulares não promovam os procedimentos necessários para o levantamento da quantia indenizatória, aplica-se o artigo 100 do Código de Defesa do Consumidor, revertendo-se o valor em favor do fundo disposto em lei: "Art. 100. Decorrido o prazo de um ano sem habilitação de interessados em número compatível com a gravidade do dano, poderão os legitimados do art. 82 promover a liquidação e execução da indenização devida. Parágrafo único. O produto da indenização devida reverterá para o fundo criado pela Lei n. ${ }^{\circ} 7.347$, de 24 de julho de $1985^{\prime \prime}$.

${ }^{55}$ Conforme ZAVASCKI, Teori Albino. Defesa de direitos coletivos e defesa coletiva de direitos. In Revista de processo, n. 78, abril-junho de 1995, ano 20, p. 34 e 37; e MAZZILLI, Hugo Nigro. A defesa dos interesses difusos em juízo. $25^{\text {a }}$ Ed. São Paulo: Editora Saraiva, 2012, p. 57.

${ }^{56}$ Esse dado é de grande utilidade quando da análise dos sistemas indenizatórios que serão estudados (VOO TAM 3054 E VOO AIR FRANCE 447, p. 177), já que eles comportarão duas fases. Em uma primeira, na qual o conflito é tratado de forma coletiva, visa-se à adoção e ao desenho de um mecanismo adequado. Já na segunda fase, tratativas individualizadas buscarão a melhor solução para os diversos conflitos homogêneos provenientes de uma mesma origem. 
Desse modo, para a tutela individual de direitos individuais homogêneos, seus próprios titulares têm legitimidade processual ativa. Ademais, pode-se aplicar a técnica processual do litisconsórcio ativo facultativo, uma vez que estes direitos são, de fato e juridicamente, afins. ${ }^{57}$ Contudo, para viabilizar a tutela coletiva, o ordenamento nacional prevê o regime de substituição processual. ${ }^{58}$

Tanto os próprios titulares, como seus substitutos e os que têm função de proteção dos interesses coletivos lato sensu, à luz da adequada tutela e da multiplicidade de meios de solução de conflito, podem escolher ou até mesmo criar um que seja capaz de prover o melhor tratamento aos conflitos, por exemplo, criando um sistema que facilite a indenização de vítimas e beneficiários de um determinado acidente aéreo.

A criação de um sistema de solução de conflito personalizado torna-se possível, uma vez que a origem comum e a homogeneidade criam conflitos de mesmo tipo. Paralelamente, o ordenamento jurídico nacional, por meio do artigo $4^{\mathrm{o}}$ do Código de Defesa do Consumidor, ${ }^{59}$ estimula que sejam criados e adotados mecanismos eficientes de solução de conflitos de consumo. Considerando o ideário do DSD, cabe ainda destacar o emprego, pelo legislador, do termo "criação" no dispositivo: "incentivo à criação pelos fornecedores [...] de mecanismos alternativos de solução de conflitos de consumo".

Com o desenho de um sistema feito sob medida, oferta-se às partes não apenas mais uma opção para solucionar seus conflitos, ${ }^{60}$ mas sim, um mecanismo especialmente idealizado para ofertar o tratamento mais adequado à questão. Considerando direitos individuais homogêneos, deve-se pensar em um sistema que responda adequadamente às características dos conflitos e, desse modo, que tome proveito das facilidades trazidas pela

\footnotetext{
${ }^{57}$ Conforme artigo 46, inciso VI, do Código de Processo Civil: “Art. 46. Duas ou mais pessoas podem litigar, no mesmo processo, em conjunto, ativa ou passivamente, quando: IV - ocorrer afinidade de questões por um ponto comum de fato ou de direito".

${ }_{58}$ Conforme ZAVASCKI, Teori Albino. Defesa de direitos coletivos e defesa coletiva de direitos. In Revista de processo, n. 78, abril-junho de 1995, ano 20, p. 37.

59 Artigo $4^{\mathrm{o}}$ : “A Política Nacional das Relações de Consumo tem por objetivo o atendimento das necessidades dos consumidores, o respeito à sua dignidade, saúde e segurança, a proteção de seus interesses econômicos, a melhoria da sua qualidade de vida, bem como a transparência e harmonia das relações de consumo, atendidos os seguintes princípios: V - incentivo à criação pelos fornecedores de meios eficientes de controle de qualidade e segurança de produtos e serviços, assim como de mecanismos alternativos de solução de conflitos de consumo;

${ }^{60}$ Utiliza a expressão "mais uma opção", tendo em vista a multiplicidade de mecanismos que podem ser empregados para a solução do conflito. Esta multiplicidade é mais bem analisada no tópico PLURALIDADE DE MECANISMOS DE SOLUÇÃO DE CONFLITO, p. 48.
} 
tutela coletiva, como a celeridade e a coerência sistêmica, assim como dos benefícios da possibilidade de individualização, efetivando a solução mais adequada para cada titular.

\subsubsection{RESPONSABILIDADE CIVIL E INTERESSES INDIVIDUAIS HOMOGÊNEOS DOS CONSUMIDORES}

Há um dever geral de não causar prejuízos a ninguém, “expresso pelo Direito Romano através da máxima neminem laedere". 61 O dano e sua reparação são objetos de estudo da responsabilidade civil. Esta, por sua vez, é tema de direito material, o que faz com que se tenha que lançar mão da interdisciplinaridade para uma análise adequada.

Conforme entendimento de Caio Mário da Silva Pereira, a teoria da responsabilidade civil é "a imputação do resultado da conduta antijurídica, e implica necessariamente a obrigação de indenizar o mal causado". ${ }^{62}$

Maria Helena Diniz lembra que a conduta, omissiva ou comissiva, geradora do dano não precisa ser necessariamente ilícita. Segundo a autora, a conduta deve apenas ser qualificada juridicamente, podendo configurar tanto um ato ilícito, como um lícito, já que, entre os fundamentos da responsabilidade civil previstas no Código Civil está, juntamente com a culpa lato sensu, o risco. ${ }^{63}$ Silvio Rodrigues segue a mesma linha: "há hipóteses em que a lei ordena a reparação do prejuízo experimentado pela vítima ainda quando o comportamento da pessoa obrigada a repará-lo não envolve a violação da lei”. ${ }^{64}$

Paralelamente, para Álvaro Villaça Azevedo e Sergio Cavalieri Filho, a responsabilidade civil não é obrigação de indenizar o dano, mas sim, dever de indenizar o dano, por mais que o Código Civil de 1916, em seu artigo 159, utilize-se do vocábulo

\footnotetext{
${ }^{61}$ Conforme CAVALIERI FILHO, Sérgio. Programa de responsabilidade civil. $4^{\mathrm{a}}$ Ed. São Paulo: Malheiros, 2003, p. 25.

${ }^{62}$ Conforme PEREIRA, Caio Mário da Silva. Instituições de Direito Civil: Introdução ao Direito Civil, Teoria Geral de Direito Civil. Vol. 1. 21 a Ed. Rio de Janeiro: Editora Forense, 2005, p. 660.

${ }^{63}$ Conforme DINIZ, Maria Helena. Curso de direito civil brasileiro. 19a Ed. São Paulo: Saraiva, 2005, p. 42.

${ }^{64}$ Conforme RODRIGUES, Silvio. Direito Civil: Responsabilidade Civil. Vol.4. 20ª Ed. São Paulo: Saraiva, 2003, p. 13
} 
“obrigação". ${ }^{65}$ Este dever surge em face do descumprimento do dever obrigacional, seja pelo devedor não observar os preceitos estabelecidos em um contrato, seja por não observar o sistema normativo, seja por imposição legal ou devido ao risco da atividade. ${ }^{66}$ Ou seja, "a responsabilidade civil é um dever sucessivo que surge para recompor o dano decorrente da violação de um dever jurídico originário". ${ }^{67}$

Além disso, obrigação e responsabilidade são institutos distintos, uma vez que o primeiro constitui uma relação jurídica originária e a segunda uma relação jurídica derivada.

A configuração da responsabilidade civil ocorre por meio da verificação da existência de seus pilares de sustentação. Estes pilares são os pressupostos da responsabilidade civil.

A doutrina, contudo, não é pacífica quanto a estes, por mais que apresente visões próximas. ${ }^{68}$ Alguns doutrinadores, como Caio Mário da Silva Pereira, ${ }^{69}$ Maria Helena Diniz ${ }^{70}$ e Sérgio Cavalieri Filho, ${ }^{71}$ entendem que a responsabilidade civil é sustentada por um tripé: i) conduta, ii) nexo causal e iii) dano. Todavia, enquanto Sérgio Cavalieri Filho entende que a conduta deve ser culposa em sentido amplo, ou seja, dolosa ou culposa stricto sensu, Caio Mário da Silva Pereira não defende que a conduta deva ser dolosa ou culposa, mas sim que deva ser antijurídica. Já Maria Helena Diniz vai além, considerando as possibilidades de responsabilização pelo risco da atividade, aponta ainda a possibilidade da conduta ser lícita. Assim, para ela, a conduta deve ser juridicamente qualificada, como já mencionado anteriormente.

\footnotetext{
65 Código Civil, 1916, artigo 159: “a obrigação de reparar o dano imposta a todo aquele que, por ação ou omissão voluntária, negligência ou imprudência, violar direito ou causar prejuízo a outrem”.

${ }^{66}$ Conforme AZEVEDO, Álvaro Villaça. Teoria Geral das Obrigações: Responsabilidade Civil. 10 ${ }^{\mathrm{a}}$ Ed. São Paulo: Editora Atlas, 2004, p. 276.

${ }^{67}$ Conforme CAVALIERI FILHO, Sérgio. Programa de responsabilidade civil. $4^{\mathrm{a}}$ Ed. São Paulo: Malheiros, 2003, p. 26.

${ }^{68}$ Conforme TARTUCE, Flávio. Direito Civil: Direitos das Obrigações e Responsabilidade Civil. Vol.2. $4^{\mathrm{a}}$ Ed. São Paulo: Editora Método: 2009, p. 345.

${ }^{69}$ Conforme PEREIRA, Caio Mário da Silva. Instituições de Direito Civil: Introdução ao Direito Civil, Teoria Geral de Direito Civil. Vol. 1. 21 a Ed. Rio de Janeiro: Editora Forense, 2005, p. 661.

${ }^{70}$ Conforme DINIZ, Maria Helena. Curso de direito civil brasileiro. 19a Ed. São Paulo: Saraiva, 2005, p. 42.

${ }^{71}$ Conforme CAVALIERI FILHO, Sérgio. Programa de responsabilidade civil. $6^{a}$ Ed. São Paulo: Malheiros, 2005, p.41
} 
Outros juristas, como Silvio Rodrigues ${ }^{72}$ e Flávio Tartuce, ${ }^{73}$ defendem a existência de quatro pilares: i) conduta humana comissiva ou omissiva, ii) culpa genérica ou lato sensu, iii) nexo de causalidade e iv) dano.

Estes juristas acrescentam a culpa, genérica ou lato sensu entre os pressupostos da responsabilidade civil. Em parte, isso se deve ao fato do artigo 186 do Código Civil, dispositivo base da responsabilidade civil no sistema brasileiro, determinar que a ação causadora do dano deva ser voluntária, negligente ou imprudente. ${ }^{74}$ Ainda que o artigo não mencione a imperícia entre as espécies de culpa estrita, entende-se que ela também está abrangida pelo dispositivo. ${ }^{75}$

Quando da análise do conjunto normativo do tema, constata-se claramente que o regime adotado como regra geral é o da responsabilidade subjetiva, ${ }^{76}$ sendo a objetiva ou responsabilidade independente de culpa exceção.

Por mais que a responsabilidade subjetiva seja a regra no Código Civil, a culpa não é válida como pressuposto da responsabilidade civil objetiva, responsabilidade sem culpa ou de culpa presumida. Assim, considerando o exposto, deve-se optar por uma das três possibilidades existentes: a) ou estabelecem-se os pressupostos da responsabilidade civil subjetiva e objetiva de forma apartada; b) ou sustentam-se pressupostos mais genéricos, conseguindo, desse modo, abarcar as duas espécies de responsabilidade; c) ou, com base na regra do sistema de responsabilidade civil brasileiro, estabelecem-se os pressupostos da responsabilidade civil subjetiva e desconsidera-se o elemento da culpa quando da análise de responsabilidade objetiva. Para que a classificação dos pressupostos seja útil, adotar-se-á a terceira concepção, utilizando um único grupo de pressupostos, adequando-os aos casos excepcionais, como é a responsabilidade civil objetiva.

\footnotetext{
${ }^{72}$ Conforme RODRIGUES, Silvio. Direito Civil: Responsabilidade Civil. Vol.4. 20a Ed. São Paulo: Saraiva, 2003, p. 14.

${ }^{73}$ Conforme TARTUCE, Flávio. Direito Civil: Direitos das Obrigações e Responsabilidade Civil. Vol.2. $4^{\mathrm{a}}$ Ed. São Paulo: Editora Método: 2009, p. 346.

${ }^{74}$ Art. 186. Aquele que, por ação ou omissão voluntária, negligência ou imprudência, violar direito e causar dano a outrem, ainda que exclusivamente moral, comete ato ilícito.

${ }^{75}$ Conforme RODRIGUES, Silvio. Direito Civil: Responsabilidade Civil. Vol.4. 20 a Ed. São Paulo: Saraiva, 2003, p. 17.

76 "a regra geral, que deve presidir à responsabilidade civil, é a sua fundamentação na ideia de culpa". PEREIRA, Caio Mário da Silva. Instituições de direito civil: contratos, declaração unilateral de vontade, responsabilidade civil. Vol. III. 12ª Ed. Rio de Janeiro: Editora Forense, 2006, p. 562.
} 
Assim, para desenvolver esse trabalho, ter-se-á como base os seguintes pressupostos i) conduta humana, ii) culpa genérica ou lato sensu, iii) nexo de causalidade e iv) dano, sendo que para os casos de responsabilidade civil objetiva, desconsiderar-se-á a culpa genérica ou lato sensu.

Desse modo, em regra, devem se provar os quatro pressupostos. Excepcionalmente, nas hipóteses de aplicação da responsabilidade objetiva, afasta-se a análise da culpa, não excluindo, todavia, a análise dos três outros elementos remanescentes.

Entretanto, dentro do ideário de proteção ao consumidor, há uma inversão, passando a responsabilidade objetiva a ser a regra geral. ${ }^{77}$ Desse modo, torna-se necessária a comprovação de apenas três pressupostos, conduta, nexo e dano, para a configuração da responsabilidade. Como única ${ }^{78}$ exceção, o diploma legal prevê a responsabilidade subjetiva do profissional liberal. ${ }^{79}$

Ao alterar a regra geral, o ordenamento tem por objetivo proteger $\mathrm{o}$ consumidor tendo em vista sua hipossuficiência.

Existem, contudo, hipóteses de excludentes de responsabilidade, que visam quebrar seus pilares, afastar seus pressupostos. Considerando os acidentes aéreos, devido aos aspectos da situação, duas espécies de excludentes de nexo de causalidade, destacamse: o caso fortuito e força maior. Como imaginar, por exemplo, que dois aviões viriam a se chocar sobre a floresta amazônica, considerando os atuais recursos tecnológicos que

\footnotetext{
${ }^{77}$ Conforme artigos 12 e 14 do Código de Defesa do Consumidor: "O fabricante, o produtor, [...] respondem, independentemente da existência de culpa, pela reparação dos danos causados aos consumidores por defeitos [...] bem como por informações insuficientes ou inadequadas sobre sua utilização e riscos" e "O fornecedor de serviços responde, independentemente da existência de culpa, pela reparação dos danos causados aos consumidores por defeitos relativos à prestação dos serviços, bem como por informações insuficientes ou inadequadas sobre sua fruição e riscos”. No mesmo sentido: PEREIRA, Caio Mário da Silva. Instituições de direito civil: contratos, declaração unilateral de vontade, responsabilidade civil. Vol. III. 12 ${ }^{\mathrm{a}}$ Ed. Rio de Janeiro: Editora Forense, 2006, p. 563.

${ }^{78}$ Não se entende que a culpa exclusive do consumidor, prevista no artigo $14, \S 3^{\circ}$, inciso II do CDC, seja uma hipótese de responsabilidade subjetiva. Isso por que, não está analisando o culpa do agente causador do dano, assim como a culpa exclusiva do consumidor tem o condão de descaracterizar a responsabilidade do fornecedor por meio da eliminação do nexo causal entre o ato do agente o dano causa do consumidor.

${ }^{79}$ Conforme artigo $14, \S 4^{\circ}$, do Código de Defesa do Consumidor: "A responsabilidade pessoal dos profissionais liberais será apurada mediante a verificação de culpa".
} 
existem para impedir que isso ocorresse, ${ }^{80}$ ou ainda que sensores de uma aeronave congelariam e causariam uma tragédia. ${ }^{81}$ Dessa forma, será feita uma breve análise sobre essas duas excludentes.

José Aguiar Dias, ${ }^{82}$ Arnoldo Wald ${ }^{83}$ e Silvio Rodrigues ${ }^{84}$ entendem que os institutos são sinônimos. Sílvio de Salvo Venosa ${ }^{85}$ discorda, apontando que o instituto do caso fortuito, act of God, no direito anglo-saxão, decorrente de evento da natureza, enquanto a força maior seria um ato humano inelutável, como uma guerra.

Contudo, “o dispositivo [artigo 393, parágrafo único do Código Civil] leva em conta a inevitabilidade e a irresistibilidade e não se o evento decorre da natureza ou de fato humano". ${ }^{86}$ Assim, o caso fortuito é uma situação normalmente imprevisível. Já a força maior é uma situação, por mais que previsível, contra a qual não se pode resistir.

Por mais que, eventualmente, a distinção entre caso fortuito e força maior tenha relevância terminológica e científica, não apresenta qualquer utilidade prática. Isto porque, ambas produzem o mesmo efeito de afastar a responsabilidade por quebrar o nexo causal. $^{87}$

O parágrafo $3^{\circ}$ do artigo 12 do Código de Defesa do Consumidor ${ }^{88}$ limita taxativamente as hipóteses de não responsabilização do fornecedor, não prevendo entre

${ }^{80}$ Refere-se ao choque do Boeing da companhia aérea Gol e o jato Embraer Legacy 600, em 29 de setembro de 2006. Esse choque vitimou todos os 154 ocupantes da primeira aeronave. Faz-se referência ao caso no tópico DESCRIÇÃO FÁTICA DOS ACIDENTES, p. 177.

${ }^{81}$ Refere-se ao acidente no voo 447 com a aeronave da companhia Air France, um dos casos que será analisado na segunda parte deste estudo.

${ }^{82}$ Conforme DIAS, José de Aguiar. Da responsabilidade civil. Vol. 2. $5^{\text {a }}$ Ed. Rio de Janeiro: Forense, 1979, p. 361 .

${ }^{83}$ Conforme WALD, Arnoldo. Curso de direito civil brasileiro: obrigações e contratos. São Paulo: RT, 1999, p. 141.

${ }^{84}$ Conforme RODRIGUES, Silvio. Direito Civil: Responsabilidade Civil. Vol.4. 20 ${ }^{\mathrm{a}}$ Ed. São Paulo: Saraiva, 2003, p. 174.

${ }^{85}$ Conforme VENOSA, Sílvio de Salvo. Direito Civil: Responsabilidade Civil. Vol.4. $7^{\text {a }}$ Ed. São Paulo: Atlas, 2007, p. 45.

${ }^{86}$ Conforme TARTUCE, Flávio. Direito Civil: Direitos das Obrigações e Responsabilidade Civil. Vol.2. $4^{\mathrm{a}}$ Ed. São Paulo: Editora Método: 2009, p. 366.

${ }^{87}$ Conforme VENOSA, Sílvio de Salvo. Direito Civil: Responsabilidade Civil. Vol.4. $7^{\text {a }}$ Ed. São Paulo: Atlas, 2007, p. 45.

${ }^{88}$ Art. 12. O fabricante, o produtor, o construtor, nacional ou estrangeiro, e o importador respondem, independentemente da existência de culpa, pela reparação dos danos causados aos consumidores por defeitos decorrentes de projeto, fabricação, construção, montagem, fórmulas, manipulação, apresentação ou acondicionamento de seus produtos, bem como por informações insuficientes ou inadequadas sobre sua utilização e riscos. $\S 3^{\circ} \mathrm{O}$ fabricante, o construtor, o produtor ou importador só não será responsabilizado 
elas o caso fortuito e força maior. Quanto a estas ausências a doutrina não é pacífica, contudo, a impossibilidade de utilização dessas excludentes para relações de consumo seria extremada e teria como base uma não prevista teoria do risco integral.

Parte da doutrina, acertadamente, traz como solução a subdivisão dos conceitos de caso fortuito e força maior em duas espécies: internos e externos. O caso fortuito interno e a força maior interna apresentam direta ligação com a atividade empresarial e não são excludentes de responsabilidade. Já a outra espécie, os externos, não guardam qualquer relação com a atividade, sendo "imperioso admiti-lo como excludente da responsabilidade do fornecedor, sob pena de lhe impor uma responsabilidade objetiva no risco integral, da qual o Código não cogitou". 89

Especificamente quanto aos contratos de transporte aéreo, existem alguns dispositivos legais que podem incidir sobre a relação. Entre eles, há o Código Brasileiro de Aeronáutica, lei 7.565 de 1986. Quanto ao transporte aéreo internacional, existe o tratado de Varsóvia, internalizado ao nosso ordenamento pelo decreto 20.704 de 1931. Ambos dispositivos são anteriores ao Código de Defesa do Consumidor e, dessa forma, não preveem a possibilidade da relação ter natureza consumerista. Existe ainda a convenção de Montreal, promulgado pelo decreto 5.910 em 2006. Este é outro diploma que tem como objeto dispor sobre o transporte aéreo internacional.

A despeito do Código Brasileiro de Aeronáutica e dos tratados internacionais mencionados, por mais que no passado os tribunais superiores tenham afastado a aplicação do Código de Defesa do Consumidor, ${ }^{90}$ atualmente este tem prevalecido sobre aqueles, tendo em vista a força constitucional da defesa do consumidor. ${ }^{91}$

quando provar: I - que não colocou o produto no mercado; II - que, embora haja colocado o produto no mercado, o defeito inexiste; III - a culpa exclusiva do consumidor ou de terceiro.

${ }^{89}$ Parte da doutrina, acertadamente, traz como solução a subdivisão dos conceitos de caso fortuito e força maior em duas espécies: internos e externos. O caso fortuito interno e a força maior interna apresentam direta ligação com a atividade empresarial e não são excludentes de responsabilidade. Já a outra espécie, os externos, não guardam qualquer relação com a atividade, sendo "imperioso admiti-lo como excludente da responsabilidade do fornecedor, sob pena de lhe impor uma responsabilidade objetiva no risco integral, da qual o Código não cogitou". CAVALIERI FILHO, Sérgio. Programa de responsabilidade civil. $6^{a}$ Ed. São Paulo: Malheiros, 2005, p.436.

90 "O tratado não se revoga com a edição de lei que contrarie norma nele contida. perdera, entretanto, eficácia, quanto ao ponto em que existia antinomia, prevalecendo a norma legal. Aplicação dos princípios, pertinentes a sucessão temporal das normas, previstos na lei de introdução ao Código Civil. A lei superveniente, de caráter geral, não afeta as disposições especiais contidas em tratado. Subsistência das 
Frente à tutela dos direitos individuais homogêneos, não apenas os de matéria consumerista, mas todas as suas espécies, quando da configuração da responsabilidade civil e procedência da tutela coletiva, comportam uma nova etapa, qual seja, a liquidação e execução individual da sentença condenatória genérica ${ }^{92}$ por meio do transporte in utilibus. $^{93}$

Nesta ultima fase, será apurado o dano em concreto para aquele consumidor específico, para tanto "deverá comprovar a ocorrência do dano individual, o nexo causal com a situação ou conduta reconhecida na decisão, e o montante do respectivo prejuízo". ${ }^{94}$

Os sistemas de solução de conflito criados a partir das técnicas e princípios do DSD, quando voltados para direitos individuais homogêneos, também tenderão a comportar duas fases. Uma primeira seria voltada para o tratamento coletivo dos conflitos, com a criação e adoção de um mecanismo de solução de conflito específico. Na segunda fase, buscar-se-ia a solução individualizada.

\section{PREMISSAS TEÓRICAS}

\subsection{INSTRUMENTALIDADE}

Segundo Cândido Rangel Dinamarco, o conflito é uma pretensão a um bem ou situação não satisfeita. ${ }^{95}$ Em outras palavras, pode-se entender que o conflito tem início na

normas constantes da convenção de Varsóvia, sobre transporte aéreo, ainda que disponham diversamente do contido no Código de Defesa do Consumidor". Conforme julgamento da terceira turma do Superior Tribunal de Justiça (STJ) no recurso especial 58736/MG de 13.12.1995.

91 "A jurisprudência deste Superior Tribunal de Justiça se orienta no sentido de prevalência das normas do Código de Defesa do Consumidor, em detrimento das disposições insertas em Convenções Internacionais, como a Convenção de Montreal, por verificar a existência da relação de consumo entre a empresa aérea e o passageiro, haja vista que a própria Constituição Federal de 1988 elevou a defesa do consumidor à esfera constitucional de nosso ordenamento". Conforme julgamento da quarta turma do Superior Tribunal de Justiça (STJ) no agravo regimental no agravo em recurso especial 388975/MA de 17.10.2013.

92 Conforme artigos 95 e 97 do Código de Defesa do Consumidor: "Art. 95. Em caso de procedência do pedido, a condenação será genérica, fixando a responsabilidade do réu pelos danos causados" e "Art. 97. A liquidação e a execução de sentença poderão ser promovidas pela vítima e seus sucessores, assim como pelos legitimados de que trata o art. 82".

${ }_{93}$ Conforme MANCUSO, Rodolfo de Camargo. Ação civil pública: em defesa do meio ambiente, do patrimônio cultural e dos consumidores. $12^{\mathrm{a}}$ Ed. São Paulo: Editora Revista dos Tribunais, 2011, p. 385.

94 LEONEL, Ricardo de Barros. Manual do processo coletivo. São Paulo: Editora Revista dos tribunais, 2002, p. 377. 
requisição de algo por um indivíduo a outrem que se nega a atendê-la. Essa solicitação pode ter como origem um dano, uma necessidade ou uma aspiração. ${ }^{96} \mathrm{O}$ surgimento do conflito bem como sua persistência geram insatisfação, que, ainda que latente, vai de encontro ao bem estar dos indivíduos e da sociedade. ${ }^{97}$

O conflito, todavia, pode ser solucionado com o redirecionamento dos vetores conflituosos e divergentes, de forma a deixa-los congruentes. Isto pode ser alcançado pela imposição de uma decisão, por meio de um acordo ou pela desistência da pretensão ou da resistência. ${ }^{98}$

O sistema jurídico, visando afastar os malefícios do conflito, estabelece regras de conduta, para evita-lo, e o processo, como instrumento para dirimi-lo e, consequentemente, pacificar a sociedade.

O processo, assim como qualquer instrumento, não deve ser apenas útil para atingir seu fim, como também deve fazê-lo de forma eficiente e efetiva. Desse modo, por exemplo, devem ser afastadas formas inúteis, preservando apenas as necessárias para o seu bom desempenho. ${ }^{99}$

\footnotetext{
${ }^{95}$ Cândido Rangel Dinamarco define o conflito como sendo uma pretensão não satisfeita: "Conflito, assim entendido, é a situação existente entre duas ou mais pessoas ou grupos, caracterizada pela pretensão a um bem ou situação da vida e impossibilidade de obtê-lo - seja porque negada por quem poderia dá-lo, seja porque a lei impõe que só possa ser obtido por via judicial. [...] Essa situação chamasse conflito, por que significa sempre o choque entre dois ou mais sujeitos, como causa da necessidade do uso do processo. DINAMARCO, Cândido Rangel. Instituições de direito processual civil. Vol. I. $5^{\text {a }}$ Ed. São Paulo: Malheiros Editores, 2005, p. 136.

${ }^{96}$ Conforme FELSTINER, William L. F.; SARAT, Austim. The emergence and transformation of disputes: naming, blaming, claiming. In Law and society review, 1980-1981, vol. 15, p. 631-654.

${ }^{97}$ Cândido Rangel Dinamarco traz ainda em sua análise quanto à insatisfação decorrente de conflitos aspectos do Welfare State, da tendência expansionista do conflito e da litigiosidade contida estudada por Kazuo Watanabe. DINAMARCO, Cândido Rangel. Instituições de direito processual civil. Vol. I. $5^{\text {a }}$ Ed. São Paulo: Malheiros Editores, 2005, p. 146.

${ }^{8}$ Como será mais bem abordado em: PLURALIDADE DE MECANISMOS DE SOLUÇÃO DE CONFLITO, p. 48.

99 “o processo não deve conter formalidades inúteis. A existência de formalidades que possam ser suprimidas em prol da celeridade do processo e sem prejuízo para os seus fins, não condena as formalidades em si, nem valoriza a informalidade; simplesmente condena o que é inútil, o que tanto vale para o processo judicial como para qualquer outro. É justo e necessário que uma reforma processual se preocupe em abolir formalidades inúteis; não porém porque isso favoreça a celeridade do processo mas porque melhore a utilidade do processo. Suposto que o processo já não contenha formalidades inúteis, só contenha as necessárias, a abolição de qualquer delas implicará restrição da garantia do devido processo legal”. MESQUITA, José Ignácio Botelho de. As novas tendências do Direito Processual: uma contribuição para seu reexame, p. 35.
} 
Contudo, nem sempre as normas que regulam o processo ${ }^{100}$ são capazes de ofertar respostas adequadas às peculiaridades e às complexidades de conflitos reais. Em parte, isso se deve ao fato de serem genericamente estipuladas com o intuito de abranger o maior número de casos. Isso, por outro lado, traz como prejuízo a frequente incapacidade em atender satisfatoriamente especificidades e complexidades.

Entre as formas de superar essa dificuldade, pode-se apontar, por exemplo, a tutela diferenciada. ${ }^{101}$ Também, "tem-se buscado a solução naquele processo delineado pelo quadro das garantias constitucionais, cujas normas, de maior abstração permitem melhor adaptação àquelas circunstâncias estranhas à regulamentação tradicional - e transubstanciação - do processo". ${ }^{102}$

Por mais que os cientistas decomponham a realidade em partições e disciplinas, ainda assim ela preserva seu caráter complexo. ${ }^{103}$ "Por essa razão surge a necessidade de a análise jurídica trabalhar sob uma perspectiva mais aberta, considerando não apenas a realidade normativa, mas também aquela política, econômica e social na qual ela está envolvida, para além da perspectiva exclusivamente jurídica”. ${ }^{104}$

Carlos Alberto de Salles propõe como solução a instrumentalidade metodológica, que "consiste em modificar a forma de análise do direito processual. Ao invés de partir-se da norma de processo, parte-se da análise de um campo específico da realidade jurídica e social, para, verificados os condicionantes que lhe são peculiares, determinar a melhor resposta processual para o problema estudado". ${ }^{105}$

\footnotetext{
${ }^{100}$ Essa inaptidão, contudo, não é uma falha exclusiva das normas processuais, está presente também entre as normas de direito material: "Do mesmo modo que o processo não consegue abarcar a complexidade envolvida em situações conflitivas determinadas, também o direito material não consegue dela dar conta". SALLES, Carlos Alberto de. Arbitragem em contratos administrativos. $1^{\text {a }}$ Ed. Rio de Janeiro: Editora Forense, 2011, p. 27.

101 "engenhosa solução tem sido dada pela chamada tutela diferenciada, uma forma de moldar procedimentalmente o grau de cognição judicial em relação a determinados assuntos ou em determinadas situações, permitindo alterar a velocidade da prestação jurisdicional oferecida". SALLES, Carlos Alberto de. Arbitragem em contratos administrativos. $1^{\mathrm{a}}$ Ed. Rio de Janeiro: Editora Forense, 2011, p. 23.

${ }^{102}$ SALLES, Carlos Alberto de. Arbitragem em contratos administrativos. $1^{\text {a }}$ Ed. Rio de Janeiro: Editora Forense, 2011, p. 22.

${ }^{103}$ A complexidade da realidade, sua tentativa de simplificação e a interdisciplinaridade serão analisadas no tópico INTERDISCIPLINARIDADE, p. 35.

${ }^{104}$ SALLES, Carlos Alberto de. Arbitragem em contratos administrativos. $1^{\text {a }}$ Ed. Rio de Janeiro: Editora Forense, 2011, p. 27.

${ }^{105}$ SALLES, Carlos Alberto de. Arbitragem em contratos administrativos. $1^{\text {a }}$ Ed. Rio de Janeiro: Editora Forense, 2011, p. 24.
} 
Em outras palavras, defende-se que se deve partir do estudo de um campo específico, averiguar sua complexidade, peculiaridades e necessidades, para só então, por meio de avaliações das informações, buscar as respostas que melhor se encaixam, isto é, que melhor se adequam a este aspecto do campo estudado. ${ }^{106}$

Parte se de situações conflituosas da realidade, suas características, condicionantes, para, após avaliação e criação, chegar-se à melhor resposta processual. ${ }^{107}$ O ideário do DSD, como ainda será analisado, ${ }^{108}$ é congruente com a instrumentalidade metodológica, na medida em que parte-se de um problema da realidade jurídica e social, levantando seus aspectos e características para avaliação e, posteriormente, criação da resposta processual que melhor responde às peculiaridades do caso.

\subsection{AUTONOMIA PRIVADA}

O sistema jurídico brasileiro prevê como garantia a inafastabilidade da tutela judicial, ${ }^{109}$ bem como a vedação à autotutela, tornando o uso da força atribuição exclusiva do Estado. A partir apenas destas disposições, poder-se-ia chegar ao entendimento equivocado de que o processo adjudicatório judicial seria a única via prevista ou desejável pelo ordenamento.

Contudo, a despeito destas previsões, a Constituição Federal também consagra, em topografia superior, a dignidade da pessoa humana entre os fundamentos do Estado, e ainda, que todo poder emana do povo, construindo o pilar do sistema democrático

\footnotetext{
106 "A resposta da instrumentalidade metodológica é de estudar o processo a partir de um campo específico, de maneira a propiciar melhores condições para avaliação da resposta processual dada em situações de grande especificidade, permitindo uma interpretação, aplicação e adequação mais abalizada das normas processuais". SALLES, Carlos Alberto de. Arbitragem em contratos administrativos. $1^{\text {a }}$ Ed. Rio de Janeiro: Editora Forense, 2011, p. 23.

107 "Na perspectiva proposta, diversamente, o processo não se coloca como ponto de partida. Sua posição é de ponto de chegada, sem inferir uma prévia modalidade de relação ente o direito e processo, como funções independentes ou como relação necessária [...] É, portanto, a partir das características, condicionantes e peculiaridades de uma área que se deve avaliar e construir a resposta processual". SALLES, Carlos Alberto de. Arbitragem em contratos administrativos. $1^{\text {a }}$ Ed. Rio de Janeiro: Editora Forense, 2011, p. 25.

${ }^{108}$ Conforme será abordado no tópico DSD - DISPUTE SYSTEM DESIGN, p. 90.

${ }^{109}$ Art. $5^{\circ}$ Todos são iguais perante a lei, sem distinção de qualquer natureza, garantindo-se aos brasileiros e aos estrangeiros residentes no País a inviolabilidade do direito à vida, à liberdade, à igualdade, à segurança $\mathrm{e}$ à propriedade, nos termos seguintes: XXXV - a lei não excluirá da apreciação do Poder Judiciário lesão ou ameaça a direito;
} 
brasileiro. Democracia que comporta, dentro de uma nova perspectiva, a participação direta do cidadão por meio do diálogo entre os interessados que compõem o pluralismo social na construção de consensos ou, ao menos, no enriquecimento dos debates políticos. $^{110}$

Quanto à dignidade humana, é possível extrair dela a liberdade individual que, por sua vez, tem como um de seus desdobramentos a autonomia privada. ${ }^{111} 112$

Com base na autonomia privada, assegura-se ao indivíduo, entre outras liberdades, a faculdade de voluntariamente afastar a tutela jurisdicional, por exemplo, em prol da adoção de um mecanismo consensual na busca da composição do conflito. ${ }^{113}$

$\mathrm{O}$ inciso XXXV do artigo $5^{\circ}$ da Constituição Federal, que prevê a inafastabilidade da tutela judicial, ao dispor que "a lei não excluirá", pode ser entendido como uma proibição ao próprio Estado de impedir o acesso do cidadão à tutela jurisdicional. Extensivamente, extrai-se desta garantia a vedação a exclusão impositiva do acesso de alguém à tutela jurisdicional estatal.

110 "Added to the older processes of private ordering, decisional-court, legislative and administrative processes, newer processes like 'consensus building' broaden democracy's reach by involving stakeholders or interested parties in settings that engage participation beyond voting and professional representation. These processes encourage involvement in direct decision making in such matters as environmental siting and preservation, municipal government and funding, race and cultural difference issues, budgeting, socially divisive issues like abortion and affirmative action, and formal regulation and mass tort liability. Even where specific decisions are not reached or solutions to 'problems' are not found, dialogue and discourse in the public sphere offer a new 'proceduralist' theory and practice of democracy. Thus, process pluralism is clearly an important legacy of the past that has adapted to new legal and social conditions". MEADOW, Carrie Menkel. Mothers and Fathers of Invention: The Intellectual Founders of ADR. Ohio: Ohio State Journal on Dispute Resolution, 2000, p. 30.

${ }^{111}$ Atualmente, a doutrina civilista, frente à revisão da concepção voluntarista do negócio jurídico, entende inadequada a expressão "autonomia da vontade", distanciando-se de sua conotação subjetiva e psicológica e substituindo-a por "autonomia privada": "Dentro das concepções de personalização do direito privado e de valorização da pessoa como centro do direito privado, o conceito de autonomia privada é de fato o mais adequado, pois a autonomia não é da vontade, mas da pessoa. Em reforço, não há dúvida de que a vontade de per si - perdeu o destaque que exercia no passado, relativamente à formação dos contratos e dos negócios jurídicos". TARTUCE, Flávio. $O$ conceito de contrato na contemporaneidade. Disponível em: http://www.flaviotartuce.adv.br/index2.php?sec=artigos\&id=48

112 "inicialmente, percebe-se no mundo negocial plena liberdade para a celebração dos pactos e avenças com determinadas pessoas, sendo o direito à contratação inerente à própria concepção de pessoa humana, um direito existencial da personalidade advindo do princípio da liberdade. Essa é a liberdade de contratar". TARTUCE, Flávio. Manual de direito civil. 2a Ed. São Paulo: Editora Método, 2012, p. 523.

113 "A liberdade de contratar indica a possibilidade de celebrar ou não um negócio jurídico, e, no caso dos MASCs [Método Adequado de Solução de Controvérsia], a ei permite que as partes deles se valham para solucionar seus conflitos". GUERRERO, Luis Fernando. Efetividade das estipulações voltadas à instituição dos meios multiportas de solução de litígios. Orientador: Prof. Associado Carlos Alberto de Salles. Tese de doutorado apresentada na Faculdade de Direito da Universidade de São Paulo. São Paulo: 2012, p. 45. 
Isto, todavia, não impede que a própria pessoa, gozando da sua autonomia privada, opte voluntariamente por afastar a jurisdição estatal, ou seja, renuncie a essa garantia constitucional e ao seu direito de acesso, ao adotar uma via consensual ou adjudicatória privada, como a arbitragem, para solucionar seus conflitos. ${ }^{114}$

A autonomia privada é um princípio que constitui aos indivíduos a liberdade de gerir seus próprios interesses. ${ }^{115}$ Este princípio decompõe-se em diferentes aspectos, dentre os quais o de criar ou não relações jurídicas, definir com quem estabelecer estes vínculos e também seus conteúdos. ${ }^{116}$

Contudo, assim como todo direito ou princípio, não é absoluto, encontrando limitações nas normas de ordem pública, no dirigismo contatual, nos princípios sociais e nas circunstâncias fáticas. ${ }^{117}$ Com isso, o Estado cerceia a liberdade por meio de normas proibitivas e imperativas. ${ }^{118}$

Com o intuito de ilustrar estas limitações, levanta-se a previsão do Código de Defesa do Consumidor ${ }^{119}$ que obriga o fornecedor a contratar, atendendo às demandas do consumidor na medida da disponibilidade de seu estoque e dos usos e costumes. Além

${ }^{114}$ A questão é mais bem analisada em SALLES, Carlos Alberto de. Mecanismos alternativos de solução de controvérsias e acesso à justiça: a inafastabilidade da tutela jurisdicional recolocada. In: FUX, Luiz; NERY JR., Nelson; WAMBIER, Teresa Arruda Alvim. Processo e Constituição. Estudos em homenagem ao Professor José Carlos Barbosa Moreira. São Paulo: Editora Revista dos Tribunais, 2006, p.779.

115 "a autonomia privada, que constitui a liberdade que a pessoa tem para regular seus próprios interesses [...] encontrando limitações em normas de ordem pública e nos princípios sociais". "conceitua-se o princípio da autonomia privada como sendo um regramento básico, de ordem particular - mas influenciado por normas de ordem pública - pelo qual na formação do contrato, além da vontade das partes, entram em cena outros fatores: psicológicos, políticos, econômicos e sociais”. TARTUCE, Flávio. Manual de direito civil. $2^{\mathrm{a}}$ Ed. São Paulo: Editora Método, 2012, p. 524 e 527.

${ }^{116}$ PEREIRA, Caio Mário da Silva. Instituições de direito civil: contratos, declaração unilateral de vontade, responsabilidade civil. Vol. III. 12a Ed. Rio de Janeiro: Editora Forense, 2006, p. 22.

117 "Este princípio não é absoluto, nem reflete a realidade social em sua plenitude. Por isso, dois aspectos de sua incidência devem ser encarados seriamente: um diz respeito às restrições trazidas pela sobrelevância da ordem pública, e outra vai dar no dirigismo contratual, que é a intervenção do Estado na economia do contrato”. PEREIRA, Caio Mário da Silva. Instituições de direito civil: contratos, declaração unilateral de vontade, responsabilidade civil. Vol. III. 12a Ed. Rio de Janeiro: Editora Forense, 2006, p. 25. "Trata-se do direito indeclinável da parte de autorregulamentar os seus interesses, decorrente da dignidade da pessoa humana, mas que encontra limitações em normas de ordem pública, particularmente nos princípios sociais contratuais". TARTUCE, Flávio. Manual de direito civil. $2^{\text {a }}$ Ed. São Paulo: Editora Método, 2012, p. 527.

118 "[nas normas proibitivas e imperativas,] a lei ordena ou proíbe dados comportamentos sem deixar aos particulares a liberdade de derroga-los por pactos privados, ao contrário das leis supletivas, que são ditadas para suprir o pronunciamento dos interessados". PEREIRA, Caio Mário da Silva. Instituições de direito civil: contratos, declaração unilateral de vontade, responsabilidade civil. Vol. III. $12^{\mathrm{a}} \mathrm{Ed}$. Rio de Janeiro: Editora Forense, 2006, p. 25.

${ }^{119}$ Conforme artigo 39, inciso II, do Código de Defesa do Consumidor: "É vedado ao fornecedor de produtos ou serviços, dentre outras práticas abusivas: II - recusar atendimento às demandas dos consumidores, na exata medida de suas disponibilidades de estoque, e, ainda, de conformidade com os usos e costumes". 
disso, existem limitações subjetivas, como as restrições quanto à contratação com incapazes, e limitações objetivas, como a impossibilidade de se transigir direitos indisponíveis. Por fim, as limitações podem ser postas por circunstâncias fáticas como a existência de monopólio, não havendo liberdade na escolha de com quem contratar.

Ressalta-se que estas normas proibitivas e imperativas, como toda norma restritiva, não devem ser interpretadas de forma extensiva. ${ }^{120}$

Constata-se, dessa forma, que a autonomia privada colabora na construção de um ambiente favorável aos meios consensuais, tanto em relação à sua adoção, como quanto aos acordos deles provenientes, e também à criação de novos sistemas de solução de conflito.

\subsection{INTERDISCIPLINARIDADE}

A realidade é complexa, ${ }^{121}$ assim como os indivíduos. Frente a isso, as ciências visam simplificar e racionalizar essa complexidade, buscando encontrar, por baixo deste caos, alguma regra que possa ser cognoscível e controlada pela razão.

Para tanto, os elementos existentes foram agrupados, separados, classificados e conceituados. Com isso, o estudo da realidade foi dividido em áreas e disciplinas, constituindo as ciências exatas, biológicas, humanas e todas as suas subdivisões. ${ }^{122}$ São estabelecidos marcos teóricos, tipos puros, visando possibilitar que tais elementos reais sejam suscetíveis de cognição e de ciência. ${ }^{123}$ Dessa forma, o conhecimento não só foi

\footnotetext{
${ }^{120}$ Como ocorre, por exemplo, no tutela do consumidor, podendo ser a autonomia privada mitigada em favor da proteção do hipossuficiente, conforme artigo 50, inciso XXXII da Constituição Federal: "o Estado promoverá, na forma da lei, a defesa do consumidor".

121 "[a palavra complexidade] suporta [...] uma pesada carga semântica, pois que traz em seu sei confusão, incerteza, desordem. Sua primeira definição não pode fornecer nenhuma elucidação: é complexo o que não pode resumir numa palavra-chave, que não pode ser reduzido a uma lei nem a uma ideia simples [...] A complexidade é uma palavra-problema e não uma palavra-solução". MORIN, Edgar. Introdução ao pensamento complexo. Tradução Eliane Lisboa. Porto Alegre: Sulina, 2006, p. 5.

122 "Qualquer conhecimento opera por seleção de dados significativos e rejeição de dados não significativos: separa (distingue ou disjunta) e une (associa, identifica; hierarquiza (o principal, o secundário) e centraliza (em função de um núcleo de noções-chaves)". MORIN, Edgar. Introdução ao pensamento complexo. Tradução Eliane Lisboa. Porto Alegre: Sulina, 2006, p. 10.

${ }^{123}$ WEBER, Max. Economy and society. Los Angeles: University of California Press, 1978, p. 341.
} 
construído, como também sistematizado de modo a torná-lo passível de transmissão, de ensinamento.

No entanto, este pensamento disjuntivo e simplificado pode vir a falhar, ${ }^{124}$ principalmente ao tentar reporta uma realidade que não é simples. Os desmembramentos, quebras e simplificações feitas pelas disciplinas, resultam em objetos incompatíveis ou não correspondentes com a realidade.

Por isso, um pensamento interdisciplinar pode conseguir articular e reunir essas partições na busca de um pensamento mais próximo à realidade.

Os conflitos, como elementos desta realidade, tende a apresentar algum grau de complexidade. Tendo isso em mente, chega-se ao entendimento que o seu adequado tratamento deve considerar esta sua característica. Assim, pode ser imprescindível ultrapassar as fronteiras das teorias legais e jurídicas, alcançando outras ciências, como a antropologia, sociologia, relações internacionais, psicologia, economia e política. ${ }^{125}$ Articulam-se as disciplinas, que foram anteriormente separadas, buscando chegar a um melhor entendimento da realidade e, dessa forma, criar respostas mais adequadas às suas necessidades.

Visando a boa aplicação do processo, seus estudiosos não podem se furtar à análise de outros mecanismos que coexistem com o processo judicial, ${ }^{126}$ com isso alargando e aprofundando os objetivos e métodos da moderna ciência jurídica. ${ }^{127}$

\footnotetext{
124 "O conhecimento científico [...] continua sendo concebido como tendo como missão dissipar a aparente complexidade dos fenômenos a fim de revelar a ordem simples a que eles obedecem. Mas se resulta que os modos simplificadores de conhecimento mutilam mais do que exprimem as realidades ou os fenômenos de que tratam". MORIN, Edgar. Introdução ao pensamento complexo. Tradução Eliane Lisboa. Porto Alegre: Sulina, 2006, p. 5.

125 "Ours has been an eclectic field intellectually, and we have used, borrowed, and elaborated on ideas that have come to us from many different fields, not only from law and legal theory, but from anthropology, sociology, international relations, social and cognitive psychology, game theory and economics, and most recently, political theory. [...] I think our field of "ADR" or conflict resolution is richer for its multiple sources of insights and sensitivity to the interactive effects of law and legal institutions with other social institutions. If our field's purpose is to provide fair, just, and more harmonious solutions to human problems, then we will not easily be cabined to teachings from law and legal theory alone".

126 "We have learned to see legal institutions as part of larger ecology in which various dispute institutions interact and affect one another". GALANTER, Marc. Compared to what? Assessing the quality of dispute processing. In: Denver University Law Review, n. 66, 1988-1989, p. XI.

127 "Uma tarefa básica dos processualistas modernos é expor o impacto substantivo dos vários mecanismos de processamento de litígios. Eles precisam, consequentemente, ampliar sua pesquisa para mais além dos
} 


\subsection{INTERESSE, REGRA E PODER: BASES DA SOLUÇÃO DE CONFLITOS}

Os conflitos humanos não são só inevitáveis, ${ }^{128}$ como também se apresentam das mais variadas formas. Essa variedade de tipos de conflitos, que ainda será objeto de análise mais pormenorizada, é fruto da ampla gama de combinações possíveis de fatores como o objeto e o desenvolvimento do conflito, além da espécie de relação da qual este se originou.

Essa pluralidade, todavia, não é exclusiva dos conflitos, está também presente nas formas utilizadas pelos seres humanos para solucioná-los.

Negociações empresariais, mediações familiares, tratados internacionais, processos judiciais, agressões físicas, greves, guerras, são apenas alguns exemplos de mecanismos encontrados pela humanidade para solucionar seus conflitos. É inegável que esses instrumentos tenham a potencialidade de solucionar conflitos ou, ao menos, parcela dele. No entanto, por mais que possam ser classificados, de forma ampla, como meios de solução de conflitos, parece ser incongruente juntar, em um mesmo grupo, a mediação de familiares e a guerra. Esse estranhamento ocorre porque esses mecanismos apresentam racionalidades diferentes, ou seja, estão baseados em um conjunto de ideias, normas e princípios diferentes.

Existem três formas básicas de solucionar um conflito: ${ }^{129}$ reconciliando interesses, determinando quem está certo com base em um conjunto de regras ou determinando quem é o mais poderoso. O conflito ocorre em um contexto no qual estão presentes os interesses das partes, suas forças, como também, parâmetros mínimos do que

tribunais e utilizar os métodos de análise da sociologia, da política, da psicologia e da economia, e ademais, aprender através de outras culturas. O 'acesso' não é apenas um direito social fundamental, crescentemente reconhecido; ele é, também, necessariamente, o ponto central da moderna processualística. Seu estudo pressupõe um alargamento e aprofundamento dos objetivos e métodos da moderna ciência jurídica". CAPPELLETTI, Mauro; GARTH, Bryant. Acesso à justiça. Tradução Ellen Gracie Northfleet. Porto Alegre: Sergio Antonio Fabris Editor, 2002, p. 13.

${ }^{128}$ FOLLETT, Mary Parker. Prophet of management: a celebration of writings from the 1920s. Beard Books, 1996, p. 67.

129 "three ways to resolve a dispute: reconciling the interests of the parties, determining who is right, and determining who is more powerful". URY, William L.; BRETT, Jeanne M.; GOLDBERG, Stephen B. Getting disputes resolved: designing systems to cut the cost of conflict. $1^{\mathrm{a}}$ Ed. São Francisco: Jossey-Bass Publishers, 1988, p. 4. 
seria uma solução certa e justa. Desta análise, chega-se aos três elementos básicos em uma disputa: interesse, regras ${ }^{130}$ e poder.

Devido à importância desses elementos para o desenvolvimento de ideias que serão abordadas neste estudo, como pluralidade, custo e adequação dos mecanismos de solução de conflito, é salutar que seja investido maior tempo de análise sobre eles.

\subsubsection{INTERESSE}

O termo "interesse" tem significado vago e abstrato, o que pode dificultar seu entendimento. Dessa forma, define-se "interesse" como sendo as necessidades, desejos, preocupações e medos de um indivíduo, tudo que seja para ele importante, útil ou vantajoso. $^{131} 132$

São os interesses que fundamentam as posições apresentadas pelos sujeitos dentro de uma disputa. Todavia, nem sempre essa relação entre a posição e interesse é óbvia ou clara, às vezes, nem mesmo para a parte. As posições são os elementos tangíveis alegados pelos sujeitos do conflito como sendo sua pretensão. ${ }^{133}$

\footnotetext{
${ }^{130}$ Os autores Ury, Brett e Goldberg elencam entre as formas básicas de solucionar conflitos a determinação de quem está certo (determining who is right). A etimologia dos termos "right" leva à palavra latina rectum, que remete à retidão do fiel da balança em equilíbrio da Deusa da Justiça, na cultura grega Diké e, na romana, Iustitia. Como forma de simplificar a expressão "definir quem tem razão com base em um conjunto de regras", utilizar-se-á o termo "regras" ou a expressão "baseado em regras".

131 "Interests are needs, desires, concerns, fears - the things one cares about or wants". URY, William L.; BRETT, Jeanne M.; GOLDBERG, Stephen B. Getting disputes resolved: designing systems to cut the cost of conflict. $1^{a}$ Ed. São Francisco: Jossey-Bass Publishers, 1988, p. 5.

132 Em conceituação mais restrita, Dinamarco define interesse como sendo "uma relação de complementariedade entre a pessoa e o bem - aquela dependendo deste para satisfazer necessidades, este sendo potencialmente hábil a satisfazer necessidades das pessoas. Interesse, nesse sentido objetivo, não é ideia que guarde necessária relação com as aspirações dos sujeitos, ou seja, com a postura mental destes em relação ao bem". DINAMARCO, Cândido Rangel. Instituições de direito processual civil. Vol. I. $5^{\mathrm{a}}$ Ed. São Paulo: Malheiros Editores, 2005, p. 136.

${ }^{133}$ URY, William L.; BRETT, Jeanne M.; GOLDBERG, Stephen B. Getting disputes resolved: designing systems to cut the cost of conflict. $1^{\text {a }}$ Ed. São Francisco: Jossey-Bass Publishers, 1988, p. 5.
} 
Não se deve confundir o conceito de interesse utilizado neste trabalho com o interesse processual da condição da ação "interesse de agir". Este remete à utilidade da prestação jurisdicional, que deve ser necessária e adequada. ${ }^{134}$

Para esclarecer essa questão sobre interesse e posição, será utilizada como ilustração uma conversa hipotética de um casal sobre a compra de um carro novo. $\mathrm{O}$ marido propõe que se compre um carro esportivo, de bom design e motorização. A esposa, por sua vez, indica um carro maior e confortável. Estão postas as posições, de um lado tem-se o carro esportivo, do outro um carro grande e confortável. Quais seriam os interesses que fundamentariam tais posições? Os interesses que dão origem à posição do marido é o sonho que tem desde criança de ter um carro esportivo e também impressionar os amigos do trabalho. A esposa tem como interesse um carro que a traga facilidades na hora de colocar as compras no carro ou as bagagens para as viagens que tanto gosta de fazer.

Solucionar um conflito com base em interesse, ou seja, na conciliação destes dá-se por meio da comunicação, instrumento pelo qual as partes apresentarão seus interesses ou pelo qual serão aplicadas técnicas visando o levantamento destas informações, ainda que seja para descobrir que o sujeito é não tem interesse em expô-los.

Posteriormente, deve-se encontrar a intersecção das esferas de interesse das partes. Essa área comum demarca os pontos sobre os quais as partes convergem. Esses pontos têm em si a potencialidade de dar origem a uma solução consensual. Para tanto é necessário um diálogo real, no qual haja efetiva participação dos sujeitos do conflito e que seja confortável o suficiente para que elas possam expor-se seus verdadeiros interesses de forma honesta. Além disso, deve-se estar atento às soluções criativas, que devem contar com a adesão ${ }^{135}$ das partes. ${ }^{136}$

Existem, no entanto, dificuldades para a apresentação dos interesses. Primeiro, é necessário que a parte saiba identifica-los e expressá-los de forma adequada.

\footnotetext{
${ }^{134}$ Conforme CINTRA, Antonio Carlos de Araújo; GRINOVER, Ada Pellegrini; DINAMARCO, Cândido Rangel. Teoria Geral do Processo. 22a Ed. São Paulo: Malheiros Editores, 2006, p. 275.

${ }^{135}$ Para que haja a adesão das partes, muitas vezes é necessária motivação. Técnicas de motivação serão analisadas no tópico RECURSOS: MOTIVAÇÃO, HABILIDADES, p. 153.

${ }^{136}$ Conforme URY, William L.; BRETT, Jeanne M.; GOLDBERG, Stephen B. Getting disputes resolved: designing systems to cut the cost of conflict. $1^{\text {a }}$ Ed. São Francisco: Jossey-Bass Publishers, 1988, p. 6.
} 
Paralelamente, todas essas informações devem ser recebidas e trabalhadas pela outra parte para que haja o devido desenvolvimento do processo de solução de conflito. Eventualmente, existe a necessidade de lidar com mais um fator, as emoções. Algumas técnicas de como lidar com as emoções na solução de conflitos por meios consensuais ainda serão abordadas. ${ }^{137}$

Considerando o que foi posto, constata-se que a busca de soluções baseadas em interesses (interests-based) dá-se por meio de mecanismos consensuais. ${ }^{138}{ }^{139}$ Ressalta-se, todavia, que por mais que essa espécie de solução seja alcançada com a utilização de vias consensuais, o oposto não é sempre verdadeiro. Nem todo mecanismo consensual busca conciliar interesses.

Além de terem base em interesse, os meios consensuais podem também ter base em regras (rights-based) ou base em força (power-based), formas básicas de solução de conflito que serão analisadas em seguida.

Não só os meios consensuais podem ter como base as três racionalidades, como isso pode ocorrer de modo simultâneo. Em um mesmo procedimento consensual é possível encontrar aspectos de mais de um tipo, por exemplo, ao se resolver alguns aspectos do conflito com base em interesse e outros com base em regras e/ou força. Nestes casos, esses mecanismos são classificados conforme a predominância de um ou de outro tipo puro. Mais uma vez, a realidade mostra-se mais complexa, não apresentando a pureza prevista pelas classificações. ${ }^{140}$

\subsubsection{REGRA}

Como mencionado no começo desta parte do estudo, o conflito ocorre em um contexto no qual, entre outros elementos, estão presentes parâmetros mínimos do que seria

\footnotetext{
${ }^{137}$ Conforme será analisado no tópico CARACTERÍSTICAS DOS MECANISMOS CONSENSUAIS, p. 69. ${ }^{138}$ RACIONALIDADE DOS MECANISMOS CONSENSUAIS, p. 61.

${ }^{139}$ Conforme URY, William L.; BRETT, Jeanne M.; GOLDBERG, Stephen B. Getting disputes resolved: designing systems to cut the cost of conflict. $1^{\text {a }}$ Ed. São Francisco: Jossey-Bass Publishers, 1988, p. 6.

${ }^{140}$ Conforme WEBER, Max. Economy and society. Los Angeles: University of California Press, 1978, p. XXXVIII.
} 
uma solução certa e justa. Procedimentos baseados nestes parâmetros, isto é, baseados em regras (rights-based), são outra opção na tentativa de compor o conflito. Esses mecanismos respaldam-se em normas, padrões independentes, com notória legitimidade e justiça para determinar quem está com a razão. ${ }^{141}$

Essas normas podem estar tanto formalizadas, como as leis ou negócios jurídicos previstos em contrato entre os litigantes, ou não. Ainda que não estejam formalizadas, são normas de conduta socialmente aceitas, como a reciprocidade, a precedente, a igualdade, os costumes ou antiguidade.

Cabe destacar que se utiliza o termo "regra" de forma a abranger não só as leis, normas estatais, mas sim, toda e qualquer norma de conduta que tenha legitimidade dentro da comunidade em que se encontram as partes conflitantes.

Todavia, essa forma base de solução de conflito encontra como empecilho os problemas das ordens ou ordenamentos normativos. A pluralidade de normas e as relações entre elas, decorrências naturais de qualquer conjunto normativo, são as origens desses problemas. Esses padrões normativos se propõem a ser unos, sistemáticos e completos. Contudo, são correntes questões de interpretação de norma, antinomias e lacunas. ${ }^{142}$ Paralelamente a essas anomalias que ocorrem internamente ao ordenamento, existe ainda a possibilidade de aplicação de sistemas distintos, ocasionalmente incongruentes, a uma mesma situação conflituosa.

Por exemplo, a um conflito que se instaure entre membros de uma comunidade religiosa, devem ser aplicadas as normas religiosas dessa comunidade ou as regras previstas pelo Estado? Qual é o sistema mais adequado à esta situação ou qual é o conjunto normativo mais adequado a ser aplicado?

Essas divergências e obscuridades das normas fazem com que, muitas vezes, as partes tenham uma percepção errada sobre seu direito. Dessa forma, os indivíduos em

\footnotetext{
${ }^{141}$ URY, William L.; BRETT, Jeanne M.; GOLDBERG, Stephen B. Getting disputes resolved: designing systems to cut the cost of conflict. $1^{\mathrm{a}}$ Ed. São Francisco: Jossey-Bass Publishers, 1988, p. 7.

${ }^{142}$ BOBBIO, Norberto. Teoria do ordenamento jurídico. 10ª Ed. Brasília: UNB, 1999, 31 e 34.
} 
conflito, mesmo utilizando-se de um mesmo padrão normativo, podem entender que estão certas. $^{143}$

As partes teriam o desafio de chegar a um consenso quanto a como superar esses problemas, qual padrão normativo aplicar, quais normas utilizar dentro deste sistema, como interpretá-las, quais normas procedimentais, quais normas de natureza material. Diversos outros questionamentos poderão surgir e as partes, já em conflito, terão dificuldade em superar tais entraves.

Possível solução seria a escolha de um terceiro, para que ele, com base em regras, aponte quem está certo e resolva possíveis outros questionamentos que venham a aparecer.

Como exemplos de procedimentos mais adaptados a essa racionalidade, têm-se a arbitragem e o processo judicial, mecanismos adjudicatórios, isto é, procedimentos nos quais um terceiro, após analisar a questão, proferirá uma solução.

Diferentemente do que ocorre com procedimentos baseados em interesse, nos quais a solução é buscada na conciliação de interesses, sendo próprio de mecanismos consensuais, nos procedimentos baseados em regras, ${ }^{144}$ normalmente, estabelece-se uma competição ${ }^{145}$ entre as partes para verificar quem está certo, tem razão, tem direito. Dessa forma, as partes disputam entre si o convencimento do julgador de que os argumentos que apresentam estão conforme o padrão normativo utilizado.

\footnotetext{
${ }^{143}$ Tercio Sampaio Ferraz Júnior buscando a definição para direito, ao analisar seus diferentes aspectos, elabora ilustração válida para a questão apresentada quanto ao conflito de entendimentos e de percepções: "De uma parte, [o direito] consiste em um grande número de símbolos e ideais reciprocamente incompatíveis, o que o homem comum percebe quando se vê envolvido em um processo judicial: por mais que esteja seguro de seus direitos, a presença de outro, contestando-o, cria-lhe certa angústia que desorganiza sua tranquilidade". FERRAZ JÚNIOR, Tercio Sampaio. Introdução ao estudo do direito: técnica, decisão, dominação. $4^{\text {a }}$ Ed. São Paulo: Editora Atlas, 2003, p. 32.

${ }^{144}$ Não é possível afirmar que todos os mecanismos baseados em regras estruturam-se em uma competição para definir quem está certo, tem razão ou direito, já que mecanismos consensuais também podem ter como base direito.

${ }^{145}$ O termo "competição" será utilizado repetidas vezes ao longo desse estudo e deve ser entendido de modo amplo, como qualquer forma de concorrência entre dois ou mais sujeitos quanto a um mesmo bem, em que cada um desses sujeitos busca a superação ou a vitória sobre o outro.
} 


\subsubsection{PODER}

Por fim, analisar-se-á a terceira forma elementar de solução de conflitos, os procedimentos baseados em poder (power-based). Utiliza-se como definição para "força" ou "poder" a habilidade de constranger alguém a fazer algo que por outras razões não o faria. ${ }^{146}$ Normalmente, exercer a força implica impor custos a outra parte ou ameaça-la com algo indesejável. Pode ocorrer de forma ativa, como um ataque físico, ou de forma passiva, como se negar a repassar os benefícios naturais da relação. ${ }^{147}$

Em uma relação de interdependência, ${ }^{148}$ o quesito poder pode ser mais bem mensurado não por meio da pergunta “quem é mais poderoso?", mas sim, “quem é menos dependente?".

Prosseguindo com a análise do poder como elemento base para a solução de conflitos, tem-se que, apesar dos indicadores objetivos de poder, como recursos financeiros, deve ser acrescida mais uma variante, a percepção das partes dos seus próprios poderes e, principalmente, dos poderes do adversário. Quanto a essa última, não se costuma ter todas as informações necessárias para um cálculo adequado. Assim, normalmente, estas percepções dos sujeitos acabam sendo incongruentes, não só entre si, mas também incongruentes em relação aos elementos fáticos, à realidade. Esses erros de percepção tornam o procedimento ainda mais custoso e inadequado. Como exemplo de erro de percepção, pode-se indicar um evento histórico, a guerra do Vietnã.

As possibilidades são muitas e as informações que as partes possuem podem não ser suficientes para realizar a "jogada" correta. Não há certeza de como a outra parte agirá, como e onde alocará seus recursos. Com isso, as combinações se multiplicam e, assim, uma batalha que se mostrava de rápido desfecho, com a vitória de uma das partes, prolongar-se indeterminadamente, causando o enfraquecimento dos dois lados.

\footnotetext{
${ }^{146}$ A verificação da licitude de procedimentos baseados na força não será analisada de forma exaustiva por extrapolar o objeto deste trabalho. Ademais, como uma forma base de solução de conflitos, essa racionalidade comporta inúmeros casos que vão de discussões a guerras mundiais, o que merece e necessita de estudo extenso e cauteloso.

${ }^{147}$ URY, William L.; BRETT, Jeanne M.; GOLDBERG, Stephen B. Getting disputes resolved: designing systems to cut the cost of conflict. $1^{\mathrm{a}}$ Ed. São Francisco: Jossey-Bass Publishers, 1988, p. 7.

${ }^{148}$ Entende-se por "relação de interdependência" toda relação entre indivíduos, independentemente da sua natureza, econômica, familiar ou outra qualquer, na qual os sujeitos dependam, em alguma medida e por alguma razão, mutuamente, mas não, necessariamente, de modo igualitário.
} 
Há um amplo leque de procedimentos para a solução de conflitos que podem ser baseados em poder, tanto os de baixa complexidade, como uma discussão, ou os de alta, como uma guerra.

Como foi posto, ao poder é um dos elementos naturais às disputas. Soma-se a isso o fato das relações, geralmente, serem constituídas entre sujeitos que apresentam forças díspares, ${ }^{149}$ assim como ocorre nas relações de consumo, entre pais e filhos, professores e alunos. ${ }^{150} \mathrm{O}$ que se pretende com essas afirmações é demonstrar que o elemento poder, em um grau ou outro, está frequentemente presente no cotidiano humano.

Existem, contudo, alguns mecanismos que se mostram mais adaptados a soluções com base no poder: a competição e a negociação. Na primeira hipótese, estabelece-se uma competição entre as partes para determinar o mais forte, com escalada de ameaças e ataques para definir quem prevalecerá, como uma discussão ou uma guerra. $\mathrm{Na}$ segunda, o sujeito mais poderoso constrange a parte mais fraca, desnaturando, dessa forma, o consentimento livre, a fechar um o acordo nos termos mais favoráveis e satisfatórios ele. ${ }^{151}$

Considerando o que foi apresentado no parágrafo anterior, cabe que sejam feitas as seguintes ponderação e ressalvas: o fato de mecanismos consensuais poderem ter com base a força faz com que estes entrem em contradição com a sua própria natureza e com os seus princípios e pressupostos. ${ }^{152}$ Dessa forma, por mais que possíveis, procedimentos consensuais que tenham, majoritariamente, o poder como elemento base, devem ser vistos como formas patológicas.

Mecanismos baseados em força, muitas vezes, encontram-se em uma área limítrofe entre o que pode ser considerado legal ou ilegal. Por exemplo, guerras, greves e discussões, por mais que indesejáveis, em regra, são consideradas legais ou normais na

\footnotetext{
${ }^{149}$ A disparidade de armas é melhor analisada no tópico CARACTERÍSTICAS DOS MECANISMOS CONSENSUAIS, p. 69.

${ }^{150}$ Por mais que, nos exemplos dados, seja possível a utilização de procedimentos baseados em interesse ou direito para a solução de conflitos e que estas relações, em casos concretos, possam ser fundamentadas primordialmente em outros pilares que não a força, ainda assim, este elemento está presente.

${ }^{151}$ Conforme URY, William L.; BRETT, Jeanne M.; GOLDBERG, Stephen B. Getting disputes resolved: designing systems to cut the cost of conflict. $1^{\text {a }}$ Ed. São Francisco: Jossey-Bass Publishers, 1988, p. 8.

${ }^{152}$ Este tema será desenvolvido no tópico RACIONALIDADE DOS MECANISMOS CONSENSUAIS, $p$. 61.
} 
história humana. Por outro lado, meios consensuais nos quais a força destaca-se como elemento chave para a composição do conflito, padece de nulidade ${ }^{153}$ por desnaturar a declaração de vontade ou, eventualmente, até mesmo, de inexistência, caso o constrangimento seja tanto a ponto de afastar o elemento vontade do negócio jurídico.

\subsubsection{INTERESSE, REGRA E PODER: INTER-RELAÇÃO}

Cada uma dessas formas básicas, por apresentar racionalidade própria, lida de modo diferente com o conflito e seus sujeitos e, dessa forma, alcança produtos específicos. Assim, essas peculiaridades procedimentais tornam cada tipo mais ou menos adequado para este ou aquele conflito e/ou relação. Considerando os custos de transação, satisfação com o resultado, consequências para a relação, tem-se que a reconciliação de interesses é a via menos custosa e que apresenta resultados mais satisfatórios para as partes. Em seguida, vem a definição de quem está certo e, por fim, de quem é mais forte. ${ }^{154}$

Como foi posto, alguns tipos de mecanismo, em abstrato, podem comportar mais de uma base, como ocorre com a negociação.

Outro plano de análise é a aplicação do mecanismo em concreto. É possível que, esses instrumentos apresentem mais de uma racionalidade em uma mesma aplicação, devido a sua própria natureza comportar tal dinâmica.

Como exemplo, pode-se pensar em uma negociação, na qual as partes alternam entre argumentos baseados em poder, em regras e/ou em interesse, sendo classificado conforme a racionalidade predominante. Dessa forma, seria possível que as partes, durante uma negociação, alcancem a uma solução parcial do conflito com base em regras,

\footnotetext{
${ }^{153}$ O Código Civil de 2002 prevê em seus artigos 151 e seguintes que a coação vicia a declaração de vontade, tornando o negocio jurídico anulável, nulidade relativa. Contudo, Caio Mário da Silva Pereira, a partir de uma análise mais detalhada, levanta o enquadramento em nulidade absoluta aos casos nos quais há coação física, o que, não vicia a declaração de vontade, mas sim, exclui a vontade da parte devido à vis absoluta. Segundo o autor, resistiria a hipótese de nulidade relativa, conforme previsto no código, aos casos de vis compulsiva, violência moral, circunstâncias nas quais, apesar da coação, sobreviria a declaração de vontade, todavia, com o animus deturpado. PEREIRA, Caio Mário da Silva. Instituições de direito civil: introdução ao direito civil, teria geral de direito civil. Vol. I. $21^{\text {a }}$ Ed. Rio de Janeiro: Editora Forense, 2005, p. 530.

${ }^{154}$ Conforme tópico CUSTOS DE TRANSAÇÃO, p. 116.
} 
definindo quem é o culpado e, em um segundo momento, com base em interesse, estabeleçam como se dará a indenização.

Esta dinâmica é a existente nos programas indenizatórios que serão estudados. A responsabilidade pela indenização foi definida com base nas regras do Código de Defesa do Consumidor, enquanto a individualização dos valores indenizatórios foi feita com base em regras, como o Código Civil e a jurisprudência, e também com base em interesses, durante as negociações das partes.

Para ilustrar o tratamento dos conflitos com base em interesse, regra e poder, Ury, Brett e Goldberg apresentam um conflito enfrentado por uma empresa mineradora e seus trabalhadores. ${ }^{155}$ Entende-se salutar para o presente trabalho a repetição desse exemplo, para não só exemplificar a dinâmica de interação entre os elementos base, mas também para aprofundar a análise sobre eles.

O conflito do caso analisado inicia-se quando um mineiro tem suas botas de trabalho furtadas e sua solicitação não é atendida por seu superior, sua pretensão não é satisfeita. É costume dos trabalhadores da mina, nas mudanças de turno, deixar suas roupas de mineração em um cesto enquanto estão no vestiário. É neste momento que o mineiro tem as suas botas furtadas. Ele procura o chefe de turno, para que este tome alguma providência. O trabalhador alega não achar justo que tenha que perder o dia de trabalho e, consequentemente, sua renumeração do respectivo período e ainda que tenha que pagar por botas novas, tudo isso, segundo seu entendimento, pela incapacidade da companhia para proteger os bens dos trabalhadores. Como resposta, o chefe de turno lamenta a situação, mas lembra ao trabalhador que a organização não é responsável pelos bens particulares dos seus empregados, conforme consta no regulamento da mina. Frente à resistência à satisfação de sua pretensão, origina-se o conflito.

Percebe-se, até este ponto, que o mineiro, além de buscar culpados ${ }^{156} \mathrm{e}$ posicionar-se como vítima, apresenta argumentos de direito, defendendo que sua posição estava certa e que era injusto o que estava acontecendo. Ele desenvolve esses argumentos

${ }^{155}$ URY, William L.; BRETT, Jeanne M.; GOLDBERG, Stephen B. Getting disputes resolved: designing systems to cut the cost of conflict. $1^{\text {a }}$ Ed. São Francisco: Jossey-Bass Publishers, 1988, p. 3.

${ }^{156} \mathrm{O}$ trabalhador entende que a companhia é culpada pela situação, por não oferecer a proteção devida aos bens dos seus empregados. 
com base em um padrão geral do que seria justo e certo, apesar de não indicar normas formalizadas. Por sua vez, o chefe do turno rebate com um argumento de mesma natureza, baseado em regras. Todavia, este se respalda no padrão normativo previsto no estatuto da mina. As partes fazem uso de argumentos de direito, ou seja, buscam argumentar que suas posições são as certas, justas à luz do conjunto de regras que entendem aplicáveis ao caso. Contudo, como foi supra-apresentado, em regra, as fontes de direito e as normas são vastas e eventualmente conflitantes. Após esta primeira rodada da negociação, o conflito persiste, ambos entendem que estão corretos. Além disso, foi acrescida à disputa a questão de qual norma deve ser aplicada.

Prosseguindo com o relato do caso, o minerador, irritado com a resposta que obteve da empresa e impossibilitado de trabalhar por falta dos seus equipamentos, decide convencer seus colegas a parar de trabalhar. Consegue mobilizar alguns colegas, que são seguidos pelos outros trabalhadores e todos entram em greve.

Fazendo uma nova pausa para a análise da situação, observa-se que, uma vez que os argumentos fundados em regras não surtiram o efeito esperado, solucionando a questão a seu favor, o minerador passa a usar outro elemento, a força. Assim, nesta nova tentativa de solucionar a questão, os trabalhadores buscam mostrar para a companhia que são mais poderosos que ela. Com isso, todavia, são gerados diversos custos, tanto para os trabalhadores, como para a empresa.

O conflito passa a ser tratado pelo superintendente geral da mina, que resolve rapidamente a questão, substituindo as botas furtadas. Caso o chefe de turno, assim que soubesse do furto, tivesse providenciado um par de botas para o mineiro, não teria ocorrido a greve, nem suas consequências prejudiciais existiriam.

O superintendente resolveu o conflito com base em interesse. $\mathrm{O}$ mineiro tinha interesse nas suas botas e no pagamento do turno que não conseguiria trabalhar pela falta da bota. Com as botas, pode trabalhar e receber a devida remuneração. A companhia mineradora, por sua vez, tinha interesse no trabalho dos mineradores. Por mais que existissem questões de justiça e de força, a melhor solução foi alcançada com base no interesse das partes. 


\subsection{PLURALIDADE DE MECANISMOS DE SOLUÇÃO DE CONFLITO}

Muito provavelmente, caso se pergunte para um advogado como solucionar um conflito jurídico, ele responderá prontamente "entre com um processo". Inúmeras são as razões para tal resposta, mas, a principal encontra-se na base, nas faculdades de direito. Ainda hoje, a formação acadêmica dos juristas apresenta-se voltada fortemente à solução judicial de conflitos, com base adversarial e adjudicatória. ${ }^{157}$

Contudo, inúmeras pessoas passam os anos das suas vidas sem nunca utilizarse de um processo judicial, o que não significa que elas não tiveram conflitos, mas sim, que superaram seus problemas por outros caminhos. Grande parte dos conflitos pode ser resolvida sem a presença de um juiz ou mesmo de qualquer terceiro. ${ }^{158}$

Extrai-se da observação do cotidiano humano que os indivíduos que vivem em sociedade encontram-se frequentemente em situação de conflito. A divergência de interesses e a pretensão não atendida são inevitáveis e naturais. ${ }^{159}$ Basta o convívio de dois sujeitos para que haja a tendência de que, em algum momento, instaure-se um conflito.

Além disso, este se dá das mais variadas formas: sociais, políticos, jurídicos, familiares, simples ou complexos, envolvendo diversos aspectos, causas, campos das ciências. $^{160}$

\footnotetext{
${ }^{157}$ Conforme WATANABE, Kazuo. Cultura da sentença e cultura da pacificação. In YARSHELL, Flávio Luiz; MORAES, Maurício Zanoide de (Org.). Estudos em homenagem à professora Ada Pellegrini Grinover.

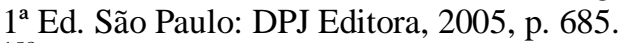

158 "A eliminação dos conflitos ocorrentes na vida em sociedade pode-se verificar por obra de um ou de ambos os sujeitos de interesses conflitantes ou por ato de terceiro". CINTRA, Antonio Carlos de Araújo; GRINOVER, Ada Pellegrini; DINAMARCO, Cândido Rangel. Teoria Geral do Processo. $22^{\mathrm{a}}$ Ed. São Paulo: Malheiros Editores, 2006, p. 26.

${ }^{159}$ Conforme analisado no tópico MECANISMOS CONSENSUAIS, p. 59.

160 "A crises verificadas na sociedade não são todas idênticas e uniformes, não sendo possível que exista um único método apto a resolver tantos e diversos impasses que, antes de serem jurídicos, foram e continuam sendo sociais". TARTUCE, Fernanda. Mediação nos conflitos civis. São Paulo: Editora Método, 2008, p. 125.
} 
Apesar dos inúmeros conflitos de variadas espécies, muitas vezes as pessoas não fazem uso das vias judiciais. Em seu lugar, elas optam, por exemplo, por conversar e entrar em acordo, desistir da pretensão ou, até mesmo, por empregar a força. ${ }^{161}$

As vias para dirimir conflitos são muitas e isto é salutar, já que proporciona um melhor atendimento à grande diversidade de conflitos. Assim como os conflitos, cada mecanismo apresenta suas características. Como será analisado no próximo tópico, considerando a perspectiva de mecanismos adequados de solução de conflitos, as qualidades do instrumento devem ser avaliadas para definir sua adequação para o tratamento de um determinado conflito.

A expressão "multi-portas", precisamente, decorre do sistema do tribunal "multi-portas". Simplificadamente, este sistema constitui uma série de programas de resolução de litígio instituídos sob uma coordenação geral dentro da competência de determinado tribunal. Além da existência de uma triagem, para encaminhar os sujeitos e seus conflitos para a porta mais apropriada, o juiz ainda pode fazer a indicação do mecanismo a ser aplicado. ${ }^{162}$

Apesar da multiplicidade, os mecanismos tendem a ser derivações dos processos primários: negociação e adjudicação. ${ }^{163}$ Como exemplos de mecanismos combinados ou secundários aponta-se a final med-arb e a final-offer arbitration.

Na primeira, há um sistema escalonado, na qual passa-se à próxima etapa caso a anterior não consiga dirimir a situação conflituosa. Especificamente na med-arb, há o emprego de meios consensuais e, caso não se chegue à composição, dá-se início a uma

\footnotetext{
${ }^{161}$ Por meio da autodefesa ou autotutela, um indivíduo impõe ao outro que este sacrifique seu interesse em seu favor. Com isso há a sobrepujança do mais forte, mais esperto sobre o mais fraco. CINTRA, Antonio Carlos de Araújo; GRINOVER, Ada Pellegrini; DINAMARCO, Cândido Rangel. Teoria Geral do Processo. $22^{a}$ Ed. São Paulo: Malheiros Editores, 2006, p. 26.

${ }^{162}$ Conforme ÁlVAREZ, Gladys S.; HIGHTON, Elena I.; JASSAN, Elías. Mediación y justicia. Buenos Aires: Depalma, 1996, p. 122.

163 "combination of the primary processes of negotiation, adjudication, and mediation in order to achieve different results dependent on the kinds of parties, issues in dispute, or numbers of parties involved". MEADOW, Carrie Menkel. Mothers and Fathers of Invention: The Intellectual Founders of ADR. Ohio: Ohio State Journal on Dispute Resolution, 2000, p. 29.
} 
arbitragem. Por isso, este mecanismo tem a capacidade de superar o problema da efetividade. $^{164}$

Na final-offer arbitration, o árbitro decide entre as propostas finais das partes apresentadas até então nas tratativas negociais. Dessa forma, os sujeitos são incentivados a apresentar propostas razoáveis. ${ }^{165}$

Em paralelo ao fato de serem derivações das formas primárias negociação e adjudicação, os mecanismos de solução de conflito têm como base interesse, regra e poder, como já estudado. ${ }^{166}$

Esta multiplicidade de mecanismos torna-se ainda maior com o ideário introduzido pelo DSD. A possibilidade de criação de sistemas de solução de conflitos complexos, com diversos aspectos para responder adequadamente às peculiaridades do conflito, amplia as possibilidades de mecanismos. Isto porque os sistemas apresentam diversos aspectos que podem ser preenchidas com uma grande variedade de elementos, que ainda podem ser comutados.

Como ilustração, pode-se pensar em um grande caldeirão no qual serão acrescentados os ingredientes ao gosto dos sujeitos e suas situações conflituosas.

Dessa forma, por exemplo, pode-se criar um sistema que combine escalonadamente negociação, mediação, conciliação e arbitragem e, paralelamente, aplique-se análise neutra de terceiro e a técnica dos parâmetros referências.

\footnotetext{
164 Como ainda será analisado no tópico O PROBLEMA DA EFETIVIDADE DOS MECANISMOS CONSENSUAIS, p. 88.

${ }^{165}$ Conforme URY, William L.; BRETT, Jeanne M.; GOLDBERG, Stephen B. Getting disputes resolved: designing systems to cut the cost of conflict. $1^{\text {a }}$ Ed. São Francisco: Jossey-Bass Publishers, 1988, p. 57.

166 Conforme tópico INTERESSE, REGRA E PODER: BASES DA SOLUÇÃO DE CONFLITOSINTERESSE, REGRA E PODER: BASES DA SOLUÇÃO DE CONFLITOS, p. 37.
} 


\subsubsection{MEIOS ADEQUADOS DE SOLUÇÃO DE CONFLITO}

A expressão "meios alternativos de solução de conflitos" foi e ainda é utilizada para designar todo e qualquer mecanismo diverso do processo judicial, abrangendo tanto os consensuais, como os adjudicatórios.

Ela tem origem na expressão “Alternative Dispute Resolution" (ADR) utilizada pela doutrina americana. Esses estudiosos exercem forte influência nesta recente retomada ${ }^{167}$ dos estudos de mecanismos, como conciliação, mediação e arbitragem. Podese indicar, como uma das fontes precursoras desse novo movimento, a obra "Access to justice: The worldwide movement to make rights effective", cujo original é de 1978, de autoria Mauro Cappelletti e Bryant Gart. ${ }^{168}$

Juntamente com a expressão americana, veio sua sigla, “ADR”, que, apesar de não ter correspondência em português, também e amplamente utilizada no Brasil para designar o conjunto dos mencionados meios.

Todavia, como será mais bem analisado ao longo este tópico, as perspectivas mudaram e passou-se a entender que a qualificação "alternativo" não seria a mais apropriada.

Com base nos diferentes significados da letra "A" na sigla "ADR", pretende-se percorrer a evolução do estudo sobre o tema. Trata-se de uma questão semântica. Contudo, palavras como "alternativo", "adequado" e "amigável”, neste contexto, são capazes de concentrar um grande número de ideias. Ou seja, afirmar que esse "A" significa "alternativo" ou "adequado" implica transmitir um conjunto de informações que modificam significativamente os elementos qualificados. A alteração da terminologia reflete uma profunda mudança do ideário do sistema de estudos dos mecanismos de solução de conflitos, o que engloba inclusive o direito processual.

\footnotetext{
${ }^{167}$ Os meios consensuais têm sua origem nos primórdios da humanidade, sendo anterior ao processo judicial ou à adjudicação de terceiro, configurando um avanço em relação à autotutela.

168 CAPPELLETTI, Mauro; GARTH, Bryant. Acesso à justiça. Tradução Ellen Gracie Northfleet. Porto Alegre: Sergio Antonio Fabris Editor, 2002.
} 
A classificação de mecanismos como negociação, conciliação, mediação e arbitragem como meios alternativos de resolução de conflitos, em sua origem, teve sua razão de ser. Isto é, os juristas da época entenderam que a utilização do termo "alternativo" era melhor forma de denominar esses meios paralelos à jurisdição estatal.

Entendia-se que estes seriam um caminho alternativo para evitar o custoso e demorado processo judicial, como se constata no trecho: "embora a conciliação se destine, principalmente, a reduzir o congestionamento do judiciário". 169

Mas, a utilização do termo "alternativo", nesta definição, apresenta dois aspectos problemáticos.

Primeiro, é uma definição fundamentada em uma negativa, em um "não ser". Ou seja, os meios alternativos não são adjudicação estatal. Essa estrutura não define o que esses mecanismos são, mas sim, o que eles não são. Com finalidade ilustrativa, é possível propor a imagem de conjuntos: dentro do vasto campo dos mecanismos de solução de conflitos, estabelece-se o contorno do conjunto do processo judicial e afirma-se que todos os outros que não estão contidos neste são alternativos.

Acrescenta-se a isso que a definição com base em uma negativa impõe à mente humana uma estrutura específica de pensamento. Para que se conheça o sentido de alternativo, é necessário que se pense, em primeiro lugar, no principal. ${ }^{170}$ Assim, não se tem um conceito que basta em si, autônomo, mas sim, dependente. Força-se o (re)conhecimento do principal, para se atingir o que realmente se pretende conhecer.

O segundo aspecto problemático da utilização de "alternativo" é que, para sua cognição, exige que se constitua uma relação mental entre o "principal" e o "alternativo".

\footnotetext{
169 “As colocações a seguir tendem a aceitar as limitações das reformas dos tribunais regulares e, como consequência, envolvam a criação de alternativas, utilizando procedimentos mais simples e/ou julgadores mais informais". CAPPELLETTI, Mauro; GARTH, Bryant. Acesso à justiça. Tradução Ellen Gracie Northfleet. Porto Alegre: Sergio Antonio Fabris Editor, 2002, p. 15, 20, 81 e 87.

${ }^{170}$ Joel Lee ilustra a questão do processamento mental de uma negativa com a análise sobre a frase: "Don't think of a pink elephant", exige-se que o indivíduo primeiro pense no elefante cor de rosa, para depois não pensar nele: "saying to someone 'Don't think of a pink elephant' requires that the person think of a pink elephant first, before not thinking of it. In a similar way, the term "Alternative Dispute Resolution" meant that one had to first think of what the main form of dispute resolution was i.e. litigation before thinking of what the alternatives to it were." (LEE, Joel. The evolving " $A$ ” in ADR. 14.03.2012. Disponível em Kluwer Mediation Blog: http://kluwermediationblog.com/2012/03/14/the-evolving-\%E2\%80\%9Ca\%E2\%80\%9D-in$\operatorname{adr} /)$.
} 
Todavia, mais que simples relação, subentende-se uma ligação hierárquica. ${ }^{171} \mathrm{Com}$ isso, a simples classificação desses mecanismos como alternativos, já os desqualifica, posicionando-os como vias de "segunda linha", secundárias, favorecendo e reforçando a via estatal. $^{172}$

Existe o pensamento que mecanismos diversos da adjudicação estatal são primitivos, próximos da autotutela. Isso se deve à existência de uma quantidade menor de formas e/ou formas mais simples e a possibilidade de ausência do Estado no procedimento. Contudo, eles nem sempre foram vistos dessa forma pelos juristas brasileiros. A Constituição do Império (1824) previa a tentativa de reconciliação por vias amigáveis como indispensável para dar começo a um processo judicial. ${ }^{173}$

Esquece-se que os meios consensuais, por mais que tenham origem anterior ao Estado, sobrevivem até os dias atuais, preservando suas capacidades de auxiliar e resolver conflitos e, dessa forma, atingindo a pacificação social, escopo mor do processo.

A partir dessas críticas, decidiu-se por substituir o termo "alternativo" por “apropriado" ou "adequado". ${ }^{174}{ }^{175}$ Fica clara a mudança de postura frente aos mecanismos

${ }^{171}$ Normalmente, as relações de alternância não apresentam diferença hierárquica entre suas alternativas. Como se constata na seguinte definição para o vocábulo "Alternativo", os significados mais relevantes, conforme entendimento dos autores do dicionário, não contêm relação hierárquica: "(i) que se diz, faz ou ocorre com alternância; (ii) que oferece possibilidade de escolha, de opção; (iii) capaz de funcionar como outra resposta, remédio, saída etc; (iv) que se propõe em substituição ao sistema cultural, técnico ou científico estabelecido; (v) que representa uma opção fora das instituições, costumes, valores e ideias convencionais; (vi) [...]; (vii) (uso informal) indivíduo que, por seu modo de viver e pensar, se opõe aos costumes, valores e ideias impostos pelas sociedades industriais e tecnológicas. (Dicionário Houaiss da língua portuguesa, setembro de 2004).

${ }^{172}$ Conforme LEE, Joel. The evolving “ $A$ ” in ADR. 14.03.2012. Disponível em Kluwer Mediation Blog: http://kluwermediationblog.com/2012/03/14/the-evolving-\%E2\%80\%9Ca\%E2\%80\%9D-in-adr/.

173 "Todavia, nem sempre foi assim em nossa história jurídica. Tivemos no passado, por exemplo, a Constituição do Império (1824), que em seu art. 161 dispunha expressamente que: 'Sem se fazer constar que se tem intentado o meio da reconciliação, não começará processo algum'. E o art. 162 estabelecia que, 'para esse fim haverá juiz de paz ..."'.( WATANABE, Kazuo. Cultura da sentença e cultura da pacificação. In YARSHELL, Flávio Luiz; MORAES, Maurício Zanoide de (Org.). Estudos em homenagem à professora Ada Pellegrini Grinover. $1^{\text {a }}$ Ed. São Paulo: DPJ Editora, 2005, p. 686).

${ }^{174}$ Conforme LEE, Joel. The evolving " $A$ " in ADR. 14.03.2012. Disponível em Kluwer Mediation Blog: http://kluwermediationblog.com/2012/03/14/the-evolving-\%E2\%80\%9Ca\%E2\%80\%9D-in-adr/.

175 '“'Appropriate' dispute resolution processes recognize a fuller menu of primary and hybrid processes, including mediation, arbitration, med-arb, evaluative mediation, early neutral evaluation, summary jury, and judge trials, all of which reflect a combination of the primary processes of negotiation, adjudication, and mediation in order to achieve different results dependent on the kinds of parties, issues in dispute, or numbers of parties involved. Fuller's recognition of a "polycentric" dispute has given way to the realization that there are many kinds of polycentric disputes, some of which require public fora because they will make law for many others (e.g., negotiated rulemaking or reg-neg), but some which the parties prefer to deal with privately (e.g., the mini-trial). By 'fitting the forum to the fuss', lawyers and parties are now more 
de solução de conflito, observando-os em um mesmo nível, cada via com sua peculiaridade, com seus prós e contras.

Nesta nova perspectiva, passa-se a se ter uma visão crítica quanto aos mecanismos. Dependendo das características do conflito, uma via poderá ser mais apropriada que outras.

Entretanto, para que seja possível fazer a escolha do mecanismo mais adequado, é necessário que se conheçam suas características, o que são e como funcionam. Isso impulsionou os estudos dos meios consensuais e da adjudicação não estatal.

Não se pensa mais em "principal” e "alternativo", mas sim em adequação entre o conflito e o instrumento que será utilizado para resolvê-lo. ${ }^{176}$ Utilizam-se os meios adequados, não pela problemática do Judiciário, mas sim pelas qualidades inerentes aos mecanismos.

É possível afirmar que a realidade brasileira ainda não é essa. Não se nega a existência de avanços, como a Resolução 125 do Conselho Nacional de Justiça (CNJ), que disciplina o tratamento adequado dos $\operatorname{conflitos}^{177} \mathrm{e}$ inclusive sugere às instituições de ensino a criação de disciplinas ${ }^{178}$ que propiciem essa mudança de mentalidade. Contudo, esta resolução não tem força de lei, é apenas um ato administrativo. De qualquer forma, há movimentos de mudança e deve-se ter consciência de que não se altera a mentalidade de forma imediata, sendo esses exemplos de ações válidas para a disseminação dessa nova perspectiva.

sophisticated about analyzing which processes are appropriate for particular kinds of desired outcomes or procedures. MEADOW, Carrie Menkel. Mothers and Fathers of Invention: The Intellectual Founders of ADR. Ohio: Ohio State Journal on Dispute Resolution, 2000, p. 29.

${ }^{176}$ Conforme LEE, Joel. The evolving " $A$ " in ADR. 14.03.2012. Disponível em Kluwer Mediation Blog: http://kluwermediationblog.com/2012/03/14/the-evolving-\%E2\%80\%9Ca\%E2\%80\%9D-in-adr/.

${ }^{177}$ Resolução número 125 do Conselho Nacional de Justiça (CNJ) dispõe sobre a Política Judiciária Nacional de tratamento adequado dos conflitos de interesses no âmbito do Poder Judiciário e dá outras providências. Disponível em: http://www.cnj.jus.br/atos-administrativos/atos-da-presidencia/resolucoespreside ncia /12243-resolucao-no-125-de-29-de-novembro-de-2010

${ }^{178}$ Resolução número 125 do Conselho Nacional de Justiça (CNJ), Artigo 6 ${ }^{\circ}$ : Para desenvolvimento dessa rede, caberá ao CNJ: (...)V - buscar a cooperação dos órgãos públicos competentes e das instituições públicas e privadas da área de ensino, para a criação de disciplinas que propiciem o surgimento da cultura da solução pacífica dos conflitos, de modo a assegurar que, nas Escolas da Magistratura, haja módulo voltado aos métodos consensuais de solução de conflitos, no curso de iniciação funcional e no curso de aperfeiçoamento. 
Por fim, um novo sentindo está sendo dado ao "A" da sigla ADR, "amigável" (amicable). ${ }^{179}$ Dessa forma, negociação, conciliação e outros seriam os meios amigáveis de solução de conflitos.

O termo "amigável" concentra e transmite de forma satisfatória grande parte das características desses mecanismos. Mesmo um leigo, uma pessoa que não tenha estudado as ciências jurídicas, conseguiria compreender do que se trata, quais são as bases dessas vias. Isto é, se um indivíduo tem um conflito e deseja resolvê-lo amigavelmente, saberá para "onde" encaminhar seu problema.

Os mecanismos podem ter base consensual ou adversarial, cada qual com sua própria racionalidade. Nas vias consensuais, como analisado, ${ }^{180}$ busca-se o consenso construído pelas partes por meio de um trabalho colaborativo, não há vencedor, nem perdedor. Como exemplo de mecanismos consensuais, têm-se a negociação, a conciliação e a mediação.

Já os meios adversariais baseiam-se na adjudicação, isto é, na determinação ou imposição da solução por um terceiro, que decide conforme os argumentos apresentados pelas partes como em uma competição. Classificá-los como mecanismos amigáveis não é adequado.

Constata-se, dessa forma, que essa nova terminologia não consegue abranger todos os meios que na terminologia anterior eram nomeados de meios adequados. Isso porque os meios consensuais apresentam a participação colaborativa das partes para a construção do consenso. Já a arbitragem, como exemplo de técnica adjudicatória, baseia-se em uma estrutura adversarial.

O termo "amigável" não é adequado para qualificar a arbitragem e outros meios adjudicatórios fundados na litigância. Por outro lado, isso não impede que a arbitragem seja vista como um meio adequado de resolução de conflitos.

${ }^{179}$ Conforme LEE, Joel. The evolving " $A$ ” in ADR. 14.03.2012. Disponível em Kluwer Mediation Blog: http://kluwermediationblog.com/2012/03/14/the-evolving-\%E2\%80\%9Ca\%E2\%80\%9D-in-adr/.

${ }^{180}$ Conforme analisado no tópico RACIONALIDADE DOS MECANISMOS CONSENSUAIS, p. 61. 
Assim, "meios amigáveis de solução de conflito" são apenas os mecanismos consensuais.

Não se nega, todavia, que a arbitragem possa ter aspectos amigáveis. A escolha das partes pela arbitragem tem base amigável, já que foi necessário chegar a um consenso quanto a essa via, afastando voluntariamente a jurisdição estatal. Além disso, muitas vezes, durante o processo arbitral, as partes podem chegar a consensos quanto aos procedimentos, o que não afasta sua natureza adversarial.

Ademais, tem-se ciência que o emprego do termo "adequado" ainda não conseguiu prevalecer sobre o "alternativo", que ainda é dominante. Ainda assim, considerando a análise terminológica realizada e sua importância, optou-se por adotar neste estudo a nomenclatura "meios adequados de solução de conflito". Por mais que não seja a nomenclatura mais atual, conforme literatura estrangeira de vanguarda sobre o assunto, entende-se que essa expressão é a mais apropriada, atingindo inclusive vias adjudicatórias, que também podem ser adequadas, conforme o conflito.

Entretanto, mais que apenas um conjunto ou a qualificação de um conjunto de mecanismos, a adequação ou a expressão "mecanismos adequados" devem ser compreendidos como uma perspectiva frente aos conflitos. A adequação deve ser entendida como um princípio ${ }^{181}$ norteador dos juristas e dos sujeitos dos conflitos na busca de uma boa solução para os conflitos.

Não apenas os consensuais, a arbitragem ou a adjudicação estatal deve ter sua qualidade avaliada, mas sim todos os instrumentos que sejam empregados para solucionar conflitos. $^{182}$

Considerando a pacificação social como escopo primordial do processo, ${ }^{183}$ cabe ao processualista, como estudioso dos instrumentos de solução de conflitos jurídicos,

\footnotetext{
${ }^{181}$ Conforme será mais bem analisado no tópico PRINCÍPIO DA ADEQUAÇÃO, p. 99.

182 "Although the issue of assessing performance was raised by the claims of ADR's proponents and the challenges of its critics, the thrust of the quality discussion is not to put ADR in the dock but to challenge the quality credentials of every dispute institution, including the most established 'traditional' ones". GALANTER, Marc. Compared to what? Assessing the quality of dispute processing. In: Denver University Law Review, n. 66, 1988-1989, p. XIII.

183 CINTRA, Antonio Carlos de Araújo; GRINOVER, Ada Pellegrini; DINAMARCO, Cândido Rangel. Teoria Geral do Processo. 22 ${ }^{\mathrm{a}}$ Ed. São Paulo: Malheiros Editores, 2006, p. 30.
} 
ter sempre como alvo a busca do melhor sistema para a concretização desse fim. Deve almejar um mecanismo que não só ponha fim ao conflito, mas que o faça de forma adequada.

Não é plausível entender que uma única via, estruturada sobre generalidades, exatamente para abarcar todos os possíveis tipos de conflitos jurídicos, conseguirá solucionar adequadamente todos esses litígios. Não se põe em dúvida a possibilidade de esse mecanismo atingir seu fim, como, uma sentença ou um acordão, pondo fim ao processo, mas sim, questiona-se se alcançará a adequação, o tratamento e a solução adequada, e assim, a pacificação social.

A adequação está ligada aos custos inerentes ao mecanismo. Estes custos não são apenas os financeiros, devem ser compreendidos de forma ampla. Assim, eles envolvem também os custos de transação, a satisfação dos sujeitos do conflito com o processamento da questão e sua solução, entre outros fatores que serão mais bem analisados em tópicos próprios. ${ }^{184}$

Nesse contexto de busca pelos instrumentos adequados que tem origem o desenho de sistema de solução de conflito (Dispute System Design - DSD). Como ainda será desenvolvido, este método busca elevar ao máximo a adequação do mecanismo ao seu objeto, por meio da criação de um sistema específico, especialmente desenhado para tratar e solucionar uma determinada situação conflituosa.

\subsubsection{TIPOLOGIA DOS CONFLITOS}

A tipologia dos conflitos é a aplicação da taxologia a estes fenômenos sociais, ou seja, é a classificação dos conflitos.

Novamente, como visto no tópico sobre interdisciplinaridade, as ciências trabalham com a realidade, separando e agrupando seus elementos, com o intuito de simplificá-la e facilitar sua cognição. Estes grupos de elementos têm como base critérios

\footnotetext{
${ }^{184}$ Conforme tópico CUSTOS DO TRATAMENTO DO CONFLITO (COSTS OF DISPUTING), p. 114.
} 
escolhidos. Quanto a estes elementos de discrímen, não é adequada uma análise de certo ou errado, mas sim de útil ou inútil para este ou aquele fim.

Desse modo, além de diferentes tipos de conflitos, existem diferentes classificações.

Morton Deutsch ${ }^{185}$ e Michel Fustier, ${ }^{186}$ por exemplo, analisam os tipos de conflito sob o aspecto subjetivo. Desse modo, o primeiro autor enumera os tipos em intrapessoal, interpessoal, intracoletivo, intercoletivo e internacionais. Por sua vez, o segundo aponta a existência de conflitos internos, interpessoais, intragrupais, intergrupais e interorganizacionais.

Morton Deutsch apresenta ainda outra classificação. Nesta, os conflitos são separados "de acordo com o relacionamento entre o estado de ânimos objetivo e o estado de ânimos como é percebido pelas partes conflitantes": conflito verídico, conflito contingente, conflito deslocado, conflito mal atribuído, conflito latente e conflito falso. ${ }^{187}$

À luz do ideário do DSD, que ainda será analisado, e considerando as limitações objetivas deste estudo, dar-se-á atenção aos conflitos complexos entre coletividade e indivíduo decorrentes de relações de consumo.

Desse modo, serão relevantes para a análise de tipo tanto aspectos subjetivos, como objetivos do conflito.

Os conflitos envolvendo direitos individuais homogêneos e relações de consumo tendem a ter como estrutura subjetiva a polarização de um grupo de consumidores lesados e, do outro lado, o fornecedor responsável pelo dano. Assim, tem-se a relação conflituosa de uma coletividade com um indivíduo. Esta pluralidade de sujeitos em um dos polos induz a complexidade subjetiva do conflito.

185 Conforme DEUTSCH, Morton. A resolução do conflito: processos construtivos e destrutivos. In AZEVEDO, André Gomma de (org.). Estudos em arbitragem, mediação e negociação. Vol. 3. Brasília: Brasília Jurídica, 2004, p. 29.

${ }^{186}$ Conforme FUSTIER, Michel. O conflito na empresa. São Paulo: Martins Fontes, 1982, p. 12.

187 Conforme DEUTSCH, Morton. A resolução do conflito: processos construtivos e destrutivos. In AZEVEDO, André Gomma de (org.). Estudos em arbitragem, mediação e negociação. Vol. 3. Brasília: Brasília Jurídica, 2004, p. 38. 
Ademais, esses conflitos têm como espectadores interessados, ${ }^{188}$ por decorrências legais e políticas, as autoridades públicas, atendendo ao interesse público.

O DSD tem grande propensão para tratar e solucionar adequadamente conflitos complexos, que são os que têm aspectos de diferentes naturezas e de variadas áreas das ciências, que devem ser observados e atendidos para um adequado desfecho do conflito. Ao buscarem respostas especializadas para os diversos aspectos do conflito, os mecanismos personalizados conseguem tratar adequadamente o conflito como um todo.

Estes diferentes aspectos podem-se mostrar no plano fático como um conjunto de questões conflituosas relacionadas entre si.

Tendo como exemplos os casos de acidente aéreo que serão analisados, observa-se que não são simples conflitos jurídicos. Devido às vítimas fatais, envolve as emoções e transtornos da perda de um familiar de forma trágica e inesperada. O aspecto financeiro é grande, uma vez que remete à subsistência ou a qualidade de vida dos dependentes das vítimas fatais. Além disso, a tragédia foi de forte comoção nacional, despertando a atenção pública e o forte envolvimento das autoridades públicas.

\subsection{MECANISMOS CONSENSUAIS}

Nos anos de 1920, Mary Parker Follet observou, em seus estudos sobre conflitos humanos, que eles eram inevitáveis. Tendo isso em vista, ela propunha que, ao invés de rechaçá-los, eles deveriam ser postos a funcionar em benefício da sociedade. ${ }^{189}$

O engenheiro mecânico busca eliminar o efeito do atrito entre as peças do motor, mas também tira proveito de sua existência nos motores por correia, nos quais é

\footnotetext{
188 Segundo Morton Deutsch existem fatores que afetam os conflitos: características das partes, relacionamento prévio delas, natureza da questão que dá origem aos conflitos, ambiente em que o conflito ocorre, espectadores interessados, estratégias e táticas empregadas pelas partes, consequência para elas e para os espectadores interessados. DEUTSCH, Morton. A resolução do conflito: processos construtivos $e$ destrutivos. In AZEVEDO, André Gomma de (org.). Estudos em arbitragem, mediação e negociação. Vol. 3. Brasília: Brasília Jurídica, 2004, p. 31.

${ }^{189}$ FOLLETT, Mary Parker. Prophet of management: a celebration of writings from the 1920s. Beard Books, 1996, p. 67.
} 
indispensável o atrito da correia com a roldana para que o sistema funcione. Assim como com o atrito, deve-se tirar proveito da existência e da inevitabilidade do conflito. ${ }^{190}$

A integração que se estabelece entre as partes do conflito por meio de mecanismos consensuais é elencada como um dos possíveis benefícios. ${ }^{191}$ Esse fenômeno é uma resultante do processo de construção da solução integrativa, que é a busca pelas próprias partes do consenso de seus desejos, sem que haja o compromisso de abrir mão de algo. Essa forma de solução tem como base a comunicação das partes, a exposição de seus interesses, bem como a busca pela preservação e comunhão destes.

Mary Parker Follett constatou que as satisfatórias e duradouras soluções integrativas, não eram resultado de uma competição, nem de um "split the difference compromisse", ${ }^{192}$ mas sim da racionalidade econômica apresentada por Vilfredo Pareto, denominada como “ótima de Pareto". 193194

\footnotetext{
190 "As conflict-difference-is here in the world, as we cannot avoid it, we should, I think use it instead of condemning it, we should set it to work for us. Why not? What does the mechanical engineer do with friction? Of course, his chief job is to eliminate friction, but it is true that he also capitalizes friction. The transmission of power by belts depends on friction between the belt and the pulley.... The music of the violin we get by friction.... We talk of the friction of mind on mind as a good thing. So in business too, we have to know when to try to eliminate friction and when to try to capitalize it, when to see what work we can make it do. That is what I wish to consider here, whether we can set conflict to work and make it do something for us". MEADOW, Carrie Menkel. Mothers and Fathers of Invention: The Intellectual Founders of ADR. Ohio: Ohio State Journal on Dispute Resolution, 2000, p. 7.

${ }^{191}$ A análise de outros benefícios é feita em RACIONALIDADE DOS MECANISMOS CONSENSUAIS, p. 61.

${ }^{192}$ Em uma tradução livre, "split the difference compromisse" seria um acordo salomônico, ou seja, um acordo que soluciona um conflito dividindo as diferenças, os interesses ao meio. Assim como no relato bíblico no qual o rei Salomão propõe que se divida a criança em dois e que se dê cada metade a uma das mulheres que disputa a criança, essa é uma tática normalmente usada para solucionar conflitos de valores, encontrando o ponto médio entre as posições das partes. Por exemplo, se um quer pagar 10 e a outra parte quer receber 20, aponta-se como solução a metade da diferença, ou seja, 15, cada um cedendo em uma mesma proporção, para que ambos saiam ganhando (ou perdendo) na mesma proporção. Contudo, esta forma de acordo não satisfaz o interesse de nenhuma das partes, não sendo uma solução fundada em interesse, mas sim, em posição, conforme será melhor analisado em RACIONALIDADE DOS MECANISMOS CONSENSUAIS, p. 61.

193 "Productive efficiency means that activity should be organized to obtain the maximum output from given inputs". "Pareto efficiency incorporates two values judgments: social welfare is increased if one person is made better off and nobody worse off; and individuals are the best judges of their own welfare". BARR, Nicholas. Economics of the welfare state. $5^{\text {a }}$ Ed. Oxford: Oxford University Press, 2012, p. 43 e 46.

${ }^{194}$ Conforme MEADOW, Carrie Menkel. Mothers and Fathers of Invention: The Intellectual Founders of ADR. Ohio: Ohio State Journal on Dispute Resolution, 2000, p. 10.
} 
O conflito não é necessariamente destrutivo, pode ser construtivo, ${ }^{195}$ uma oportunidade de crescimento e aprendizado. A busca por soluções afasta a estagnação do indivíduo e da sociedade, estimulando a criatividade, curiosidade e a aquisição de novas informações. ${ }^{196}$ Tratativas consensuais podem ainda ter o condão de fortalecer grupos e indivíduos, ao demonstrarem seu ímpeto de sobrevivência, flexibilidade e possibilidade de coexistir. $^{197}$

Como será analisado nos próximos tópicos, os mecanismos consensuais conseguem potencializar os benefícios decorrentes do processo de superação dos conflitos.

\subsubsection{RACIONALIDADE DOS MECANISMOS CONSENSUAIS}

O direito processual vivencia a pluralidade dos instrumentos pacificadores, ${ }^{198}$ bem como o desafio de adequadamente aplicá-los. ${ }^{199}$ Ao se somar a essa realidade disposições constitucionais, como o modelo democrático ${ }^{200}$ e o princípio da autonomia

195 Conforme DEUTSCH, Morton. A resolução do conflito: processos construtivos e destrutivos. In AZEVEDO, André Gomma de (org.). Estudos em arbitragem, mediação e negociação. Vol. 3. Brasília: Brasília Jurídica, 2004, p. 34 e 41.

196 Conforme COSTANTINO, Cathy A.; MERCHANT, Christina Sickles. Designing conflict management systems. $1^{a}$ Ed. São Francisco: Jossey-Bass, 1996, p. XV.

197 "While many in the ADR field think of conflict as a problematic aspect of human life, requiring 'resolution' or 'management', many social theorists prefer to see conflict as variable: sometimes 'destructive', but sometimes 'constructive' or even creative, ever an opportunity for learning and growth. The sociologists Georg Simmel and Lewis Coser argued that conflict can be a very positive social force that prevents stagnation, stimulates curiosity and learning, 'airing' of problems, and the search for new solutions at both individual and social levels. Conflict can help forge identity and cohesiveness (especially when threatened from without) and can help identify what is really important. Working with both individual and social conflicts helps articulate and test what norms and rules should be applied to situations and successful 'negotiation' through conflict makes both individuals and groups stronger by demonstrating survival and flexibility skills and permitting continuity". MEADOW, Carrie Menkel. Mothers and Fathers of Invention: The Intellectual Founders of ADR. Ohio: Ohio State Journal on Dispute Resolution, 2000, p. 6. No mesmo sentido: DEUTSCH, Morton. A resolução do conflito: processos construtivos e destrutivos. In AZEVEDO, André Gomma de (org.). Estudos em arbitragem, mediação e negociação. Vol. 3. Brasília: Brasília Jurídica, 2004, p. 34.

${ }^{198}$ Conforme analisado no tópico PLURALIDADE DE MECANISMOS DE SOLUÇÃO DE CONFLITO, p. 48.

199 Conforme analisado no tópico MEIOS ADEQUADOS DE SOLUÇÃO DE CONFLITO, p.51.

200 "Os procedimentos de autocomposição são métodos de solução de conflitos mais coadunáveis com o modelo de democracia pluralista previsto no art. $1^{\circ}, \mathrm{V}$, da Constituição. Nesse contexto, deve-se preconizar, em vez do paternalismo na elaboração das leis, o estímulo a procedimentos como a negociação coletiva, o acordo coletivo, os acordos individuais, a conciliação, a mediação e arbitragem". TARTUCE, Fernanda. Mediação nos conflitos civis. São Paulo: Editora Método, 2008, p. 226. 
privada, ${ }^{201}$ tem-se um ambiente propício para o desenvolvimento dos mecanismos consensuais de solução de conflito, como a negociação, a conciliação e a mediação.

Estas vias, contudo, não podem ser agrupadas com as outras formas de solução de conflito sem que sejam feitas as devidas ressalvas.

Os mecanismos consensuais, como se depreende da própria nomenclatura, têm como base o consenso, que é a comunhão de senso, de entendimento, de vontade. Essa natureza consensual decorre da forma pela qual estes meios solucionam os conflitos: a composição dá-se com o encontro das vontades dos sujeitos.

Não é apenas na composição que o consenso mostra-se fundamental. Em regra, ele se destaca ao longo de todo o procedimento, ${ }^{202}$ desde a sua adoção ${ }^{203}$ até eventual acordo que pacifique as partes.

A princípio, para que haja o consenso, deve estar presente a colaboração (cum laborare), cooperação (cum operati). Isto é, apesar do contexto conflituoso, os sujeitos devem se conduzir conjunta e congruentemente.

Estas características, entre outras que ainda serão analisadas, ${ }^{204}$ fazem com que estes instrumentos tenham racionalidade diversa das vias que têm como base a imposição por um terceiro de uma solução fundada no poder jurisdicional. ${ }^{205}$

${ }^{201}$ AUTONOMIA PRIVADA, p. 32 .
${ }^{202}$ Como será analisado em CARACTERISTICAS DOS MECANISMOS CONSENSUAIS, p.69, uma das
característicos dos mecanismos consensuais é a possibilidade das partes, unilateralmente, desistirem das
tratativas.
${ }^{203}$ Por mais que tenham natureza consensual, não se afasta a possibilidade de que a adoção dos mecanismos
consensuais seja compulsória. Ou seja, é possível que normas jurídicas tornem obrigatórias que se passe por
um procedimento consensual, uma tentativa de conciliação, por exemplo. Isso, contudo, não está de plena
consonância com a racionalidade das vias consensuais, por haver tanto a mitigação da autonomia privada,
como da garantia de inafastabilidade da jurisdição estatal, ao se pôr impositivamente mais um obstáculo para
o seu acesso à tutela jurisdicional estatal. Apesar da possibilidade da compulsoriedade da adoção da via
consensual, como tentativa de solução do conflito, o acordo nunca poderá ser imposto, pois, dessa forma, não
haveria consenso, alterando a natureza do mecanismo.
204 Como será analisado no tópico CARACTERÍSTICAS DOS MECANISMOS CONSENSUAIS, p. 69 .
205 Carrie Menkel Meadow analisa a diferença entre a racionalidade da mediação e da arbitragem. Esta
análise pode ser, em certa medida, ampliada aos seus gêneros mecanismos consensuais e adjudicatórios: "do
particular forms of dispute resolution or problem solving institutions have their own integrity, logic, and
morality? [...] Mediation and arbitration have distinct purposes and hence distinct moralities. The morality
of mediation lies in optimum settlement, a settlement in which each party gives up what he values less, in
return for what he values more. The morality of arbitration lies in a decision according to the law of the 
Nas vias consensuais, não há substituição dos titulares dos interesses em conflito por um terceiro imparcial, seja um árbitro ou um Estado-juiz, para dizer o direito do caso concreto, definir quem está certo, para, ao fim do devido processo, impor sua decisão e pacificar o conflito. ${ }^{206}$

Por isso, não se pode afirmar que todos os princípios norteadores de um sistema processual baseado na jurisdição sejam válidos para os consensuais. Até porque, muitos deles não são compatíveis com a dinâmica dos consensuais. ${ }^{207}$ Apenas para levantar alguns exemplos, não há que se falar no princípio do livre convencimento motivado do juiz ou do duplo grau de jurisdição, nem no da adstrição do julgado. ${ }^{208}$ Por outro lado, é possível o compartilhamento de princípios que busquem resguardar a isonomia e a lealdade entre os sujeitos, como também os que indiquem a imparcialidade de um eventual terceiro facilitador, que, por mais que não decida o conflito, tem papel relevante em mecanismos como a conciliação e a mediação.

Além da forma solução, outro critério de discrímen empregado na presente análise é a postura dos sujeitos do conflito. Diferentemente do proceder idealmente congruente e colaborativo das partes nos meios consensuais, na adjudicação, os sujeitos adotam posturas divergentes e adversariais. Conduzem-se desta forma no anseio de quebrar ou desqualificar a argumentação do oponente e de atrair o entendimento do julgador, convencendo-o de que seus argumentos são válidos e que, dessa forma, merecem vencer a disputa.

contract. The procedures appropriate for mediation are those most likely to uncover that pattern of adjustment which will most nearly meet the interests of both parties. The procedures appropriate for arbitration are those which most securely guarantee each of the parties a meaningful chance to present arguments and proofs for a decision in his favor". MEADOW, Carrie Menkel. Mothers and Fathers of Invention: The Intellectual Founders of ADR. Ohio: Ohio State Journal on Dispute Resolution, 2000, p. 19.

${ }^{206}$ Conforme CARMONA, Carlos Alberto. Arbitragem e processo: um comentário à lei $n^{\circ}$ 9.307/96. $3^{\mathrm{a}} \mathrm{Ed}$. São Paulo: Editora Atlas, 2009, p. 305.

${ }^{207}$ Todavia, essa afirmação é relativizada na hipótese de mecanismos consensuais integrantes de sistemas que relacione os consensuais e aos adjudicatórios: "as regras que regulam o direito processual incidirão sobre qualquer meio jurisdicional de solucionar uma determinada controvérsia ou sobre um método consensual que esteja ligado a um método jurisdicional via escalonamento". GUERRERO, Luis Fernando. Efetividade das estipulações voltadas à instituição dos meios multiportas de solução de litígios. Orientador: Prof. Associado Carlos Alberto de Salles. Tese de doutorado apresentada na Faculdade de Direito da Universidade de São Paulo. São Paulo: 2012, p. 12.

${ }^{208}$ Quanto à adstrição do julgado, aborda-se a maior flexibilidade do objeto dos mecanismos consensuais quando da análise de suas características: CARACTERÍSTICAS DOS MECANISMOS CONSENSUAIS, p. 69. 
Por fim, as fontes legitimadoras dos mecanismos consensuais e adjudicatórios são diversas.

Enquanto as vias consensuais têm como fonte de legitimidade a autonomia privada, os mecanismos jurisdicionais, como o processo judicial e a arbitragem, fundamentam-se no ordenamento jurídico, uma vez que o julgador é investido por lei do poder jurisdicional. ${ }^{209} 210$

Constatam-se, por meio da análise dos critérios da forma de tratamento do conflito, da postura dos sujeitos e do fundamento de legitimidade do sistema, disparidades que implicam racionalidades diferentes entre os mecanismos consensuais e os adjudicatórios. A despeito dessas e de outras diferenças que ainda serão estudadas, são caminhos para a solução de conflitos e convergem quanto ao escopo de pacificar a sociedade. $^{211}$

\subsubsection{CONSENSO: NATUREZA JURÍDICA}

Os fenômenos sociais, no plano fático, tendem a ser dinâmicos, multifacetados e complexos. Tendo isso em vista, é provável que, ao se tentar enquadrá-los ${ }^{212}$ a conceitos, abstratos e estáticos, acabe-se por deformá-los, perdendo-se assim parte de sua complexidade e dinamismo.

\footnotetext{
209 Jurisdição concebida na sua tríade: atividade, função e poder, como faceta do poder estatal. DINAMARCO, Cândido Rangel. Instituições de direito processual civil. Vol. I. $5^{\text {a }}$ Ed. São Paulo: Malheiros Editores, 2005, p. 318.

${ }^{210}$ Não se pode, contudo, negar a existência de fenômenos sociais de solução de conflito que colaboram com a pacificação social, ainda que estejam afastadas das instituições estatais e jurídicas. Localizando-se em zona limítrofe das ciências jurídicas, encontram legitimidade também em fontes extrajurídicas. É o caso, por exemplo, de um líder religioso que, procurado por seguidores em conflito, soluciona a disputa, impondo sua decisão. Esta solução pode ser acatada e respeitada pelas partes, alcançando a pacificação social, ainda que esse julgamento tenha-se dado a partir de normas não jurídicas e sua legitimidade advenha de fonte externa ao ordenamento jurídico.

211 "Mas o que há de substancialmente relevante no exercício da jurisdição, pelo aspecto social do proveito útil que é capaz de trazer aos membros da sociedade, está presente também nestas outras atividades: é a busca de pacificação das pessoas e grupos mediante a eliminação de conflitos que os envolvam. Tal é o escopo social magno da jurisdição". DINAMARCO, Cândido Rangel. Instituições de direito processual civil. Vol. I.

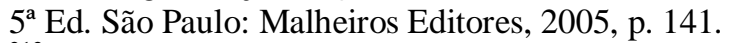

${ }^{212} \mathrm{O}$ vocábulo "enquadrar" mostra-se adequado à reflexão feita quanto ao processo de conceituação, uma vez que traz entre seus significados "tornar quadrado", deformando algo que não é quadrado e "colocar em moldura", limitando o objeto.
} 
Contudo, as conceituações e padronizações mostram-se necessárias para a realização de estudos científicos, por tornarem mais precisas e menos ruidosas as informações que se busca comunicar. "A ordem afasta a desordem, pela separação de ideias e redução, pois há coordenação de uma construção que recria o complexo a partir do simples, isto é, o paradigma da simplicidade obriga-nos a separar e reduzir, a fim de melhor compreender". 213

Ademais, especificamente quanto à definição da natureza jurídica do consenso, esta traz implicações à natureza dos meios consensuais, bem como o sistema de regras e princípios que devem ser aplicados a eles.

Por meio da análise jurídica do fenômeno social do consenso, constata-se que ele tem natureza de negócio jurídico. Sendo assim, é um ato jurídico lato sensu, que consiste na comunhão de manifestações de vontades congruentes nas quais os agentes perseguem determinado efeito jurídico. Diferencia-se do ato jurídico stricto sensu, pois neste, apesar de também estar presente uma conduta volitiva, os efeitos jurídicos "são gerados independentemente de serem perseguidos diretamente pelo agente". ${ }^{214}$

Para que o consenso se perfaça, é indispensável a existência e a coincidência de mais de uma manifestação de vontade, ${ }^{215}$ ainda que seja tácita. ${ }^{216}$ Estas manifestações fundem-se em uma declaração de vontade cercada pelas circunstâncias negociais,

213 SILVA, Érica Barbosa e. A efetividade da prestação jurisdicional civil a partir da conciliação. Orientador: Prof. Dr. Kazuo Watanabe. Tese de doutorado apresentada na Faculdade de Direito da Universidade de São Paulo. São Paulo: 2012, p. 87.

214 “[negócio jurídico] é a declaração de vontade em que o agente persegue efeito jurídico (Rechtsgeschäft), no ato jurídico stricto sensu ocorre manifestação volitiva também, mas os efeitos jurídicos são gerados independentemente de serem perseguidos diretamente pelo agente". PEREIRA, Caio Mário da Silva. Instituições de direito civil: introdução ao direito civil, teoria geral do direito civil. Vol. 1. $21^{\text {a }}$ Ed. Rio de Janeiro: Editora Forense, 2005, p. 475.

215 “o negócio jurídico bilateral pressupõe duas declarações de vontade não uma, e requer a sua coincidência sobre o objeto". "Quando as emissões volitivas se ajustam ou coincidem, [...] neste momento se diz que já é o consentimento (de cum + sentire)". PEREIRA, Caio Mário da Silva. Instituições de direito civil: introdução ao direito civil, teoria geral do direito civil. Vol. 1. $21^{\text {a }}$ Ed. Rio de Janeiro: Editora Forense, 2005, p. 496.

216 "Chama-se manifestação tácita de vontade aquela que resulta de um comportamento do agente, traduzindo a manifestação por uma dada atitude. Para o direito, [em regra,] tem eficácia a manifestação tácita de vontade, tanto quanto a expressa". PEREIRA, Caio Mário da Silva. Instituições de direito civil: introdução ao direito civil, teoria geral do direito civil. Vol. 1. $21^{\mathrm{a}}$ Ed. Rio de Janeiro: Editora Forense, 2005, p. 482. A manifestação pode se configurar uma conduta omissiva, como ocorre na hipótese de uma parte consentir com a manifestação da outra, que pode ser tanto uma conduta passiva de concordância, como uma conduta omissiva de tolerância. "é impossível não se comunicar, pois não se comunicar é comunicar que não se comunica [...] Essa comunicação admite várias linguagens (falada, por gestos, pictórica, musical etc.)". FERRAZ JÚNIOR, Tercio Sampaio. Introdução ao estudo do direito: técnica, decisão, dominação. $4^{\mathrm{a}}$ Ed. São Paulo: Editora Atlas, 2003, p. 36. 
socialmente vista como destinada à produção de efeitos jurídicos. A declaração de vontade é a unificação de manifestações de vontade congruentes, ou seja, de exteriorizações de vontades, elemento interno aos indivíduos, compatíveis entre si. ${ }^{217}$

O sistema jurídico nacional enquadra o consenso que põe fim ao conflito como um contrato típico, a transação, ${ }^{218}$ previsto no art. 840 do Código Civil. ${ }^{219}$

O dispositivo estabelece que a transação dar-se-á "mediante concessões mútuas". Todavia, tendo em vista os pontos que se têm como base neste estudo quanto à defesa da solução adequada e à comunhão de interesses, discorda-se do modus operandi previsto em lei para a constituição da transação.

Isso porque, é possível extrair da expressão "concessões mútuas", empregada pelo disposto legal, que a composição ocorre com a dilapidação parcial do interesse dos dois polos. Com isso, estabelece-se uma relação na qual as duas partes perdem, tendo-se como resultado deste fenômeno uma solução aparente ou inadequada e ainda a insatisfação dos sujeitos do conflito.

A conversão de tratativas baseadas em posições para baseadas em interesse abre a possibilidade de que haja transação, sem que seja necessário abrir mão dos interesses. Dessa forma, não se deve relacionar necessariamente a transação com concessões mútuas, que implicam perdas mútuas e que estabelecem uma relação "perdeperde". A transação deve sim ser pensada como fruto de adaptações e de criatividade empregadas na busca de interesses convergentes em um contexto de posições conflitantes.

\footnotetext{
${ }^{217}$ Antônio Junqueira de Azevedo, considerando os conceitos genéticos e funcionais do negócio jurídico, adota a definição estrutural: "Não se procurará mais saber como o negócio jurídico surge, nem como atua, mas sim, simplesmente, o que ele ê"; "Negócio jurídico é todo fato jurídico consistente em declaração de vontade, a que o ordenamento jurídico atribuiu os efeitos designados como queridos, respeitados os pressupostos de existência, validade e eficácia impostos pela norma jurídica que sobre ele incide"; "o negócio jurídico [...][é uma declaração de vontade] cercada de certas circunstâncias, as circunstâncias negociais, que fazem com que ela seja vista socialmente como destinada a produzir efeitos jurídicos". "há, nele [negócio jurídico], mais de uma vontade e mais de uma manifestação de vontade, mas essas manifestações unificam-se a visão social de uma só manifestação de vontade, que juridicamente será um só fato jurídico". AZEVEDO, Antônio Junqueira de. Negócio jurídico: existência, validade e eficácia. $4^{\mathrm{a}}$ Ed. São Paulo: Editora Saraiva, 2002 , p. 15 e seguintes.

218 "Quando as partes compõem e definem, em conjunto, o destino da pretensão, pactuam um acordo. Verificando-se no pacto concessões recíprocas, configura a transação, contrato típico previsto no art. 840 do Código Civil". TARTUCE, Fernanda. Mediação nos conflitos civis. São Paulo: Editora Método, 2008, p. 59.

${ }^{219}$ Código Civil de 2002, artigo 840: É lícito aos interessados prevenirem ou terminarem o litígio mediante concessões mútuas.
} 
A congruência de interesses ocorre mesmo nas soluções unilaterais. Estas hipóteses, como a renúncia, desistência e reconhecimento jurídico do pedido, ${ }^{220}$ não implicam violação ao interesse. Isto porque, ao renunciar, desistir ou reconhecer o pedido, por algum ou diversos fatores, internos ao sujeito, a conduta adotada encontra justificativa, constituindo, dessa forma, uma das possíveis soluções dentro de sua esfera de interesse. Um indivíduo, por exemplo, que renuncia valores quanto aos quais entende ter direito, não está violando o seu próprio interesse. Isso porque, após reflexão interna e cálculo das possibilidades, por exemplo, pode ter chegado ao entendimento que era mais interessante manter relações sociais com seu devedor e que a concessão de um desconto na dívida seria uma forma adequada para manter seu parceiro comercial.

Considerando a natureza jurídica do consenso, torna-se válida uma breve ponderação quanto aos planos da validade e eficácia jurídica do negócio jurídico. Além de institutos diversos, a validade não implica necessariamente eficácia, assim como a invalidade não implica necessariamente ineficácia. Excepcionalmente, o ordenamento admite negócios válidos ineficazes e inválidos eficazes. ${ }^{221}$

Ademais, existem fenômenos sociais juridicamente irregulares, mas que extrapolam os planos do negócio jurídico, produzindo efeitos extrajurídicos. Como exemplo, têm-se o negócio absolutamente nulo que acontece corriqueiramente quando uma criança, menor impúbere e, assim, absolutamente incapaz, compra um sorvete na padaria da esquina. Este negócio é nulo, padece de nulidade absoluta, mas é socialmente aceito e perfeito no plano dos fatos. Da mesma forma, indivíduos em conflito podem se compor, cumprir o acordado e satisfazer plenamente seus interesses, constituindo, contudo, institutos juridicamente irregulares, devido à falta de requisitos de validade ou de fatores de eficácia.

Por mais que não se defenda o seu incentivo, estes fenômenos fazem parte da realidade social estudada.

\footnotetext{
${ }^{220}$ Conforme rol apresentado na obra TARTUCE, Fernanda. Mediação nos conflitos civis. São Paulo: Editora Método, 2008, p. 53. Cintra, Grinover e Dinamarco concentram a autocomposição unilateral em duas hipóteses: submissão e desistência. CINTRA, Antonio Carlos de Araújo; GRINOVER, Ada Pellegrini; DINAMARCO, Cândido Rangel. Teoria Geral do Processo. $22^{\mathrm{a}}$ Ed. São Paulo: Malheiros Editores, 2006, p. 36.

${ }^{221}$ Conforme desenvolvido por AZEVEDO, Antônio Junqueira de. Negócio jurídico: existência, validade e eficácia. $4^{\text {a }}$ Ed. São Paulo: Editora Saraiva, 2002, 49.
} 
Como negócio jurídico, o consenso deve ser interpretado com base na boa-fé, inspirada na regra Treu und Glauben prevista no $B G B .{ }^{222}$ Dessa forma, os negócios jurídicos devem ser inspirados na lealdade e na confiança das partes e executados com fidelidade ao comungado. ${ }^{223}$ À luz da espécie objetiva, vigente em nosso ordenamento, surgem da boa-fé obrigações jurídicas anexas, com deveres como o da cooperação e correção. $^{224}$

Paralelamente à criação de deveres, a boa-fé objetiva limita direitos subjetivos. Para tanto, origina proibições, entre as quais, por terem relevância ao tema, destacam-se as do venire contra factum proprium, do inciviliter agere, da tu quoque, ${ }^{225} \mathrm{do}$ exceptio doli $\mathrm{e} \mathrm{o}$ duty to mitigate the loss. ${ }^{226}$

A natureza do consenso afeta a natureza das vias consensuais. Dessa forma, mecanismos como a negociação, a conciliação e a mediação, apesar de sua inegável natureza de instrumentos de solução de conflito, com escopo de pacificação social, sofrem, preponderantemente, influência das regras e princípios dos negócios jurídicos. Com isso, acabam por se diferenciar de mecanismos com estruturas jurisdicionais, especialmente da via adjudicatória estatal.

${ }^{222}$ Conforme PEREIRA, Caio Mário da Silva. Instituições de direito civil: introdução ao direito civil, teria geral de direito civil. Vol. I. $21^{\text {a }}$ Ed. Rio de Janeiro: Editora Forense, 2005, p. 502.

223 "Os negócios Jurídicos devem ser inspirados na boa-fé, na lealdade e na confiança das partes. Na sua execução devem guardar-lhes fidelidade, e, portanto, assim devem ser interpretados". PEREIRA, Caio Mário da Silva. Instituições de direito civil: introdução ao direito civil, teria geral de direito civil. Vol. I. $21^{\mathrm{a}} \mathrm{Ed}$. Rio de Janeiro: Editora Forense, 2005, p. 501.

224““A boa-fé, em sua concepção objetiva, como conduta ética entre as partes que negociam, impõe correção e lealdade [...] possui o condão de criar deveres jurídicos anexos, como deveres de correção, cuidado, cooperação, sigilo, prestação de contas, e mesmo de limitação do exercício de direitos subjetivos, como ocorre nas proibições de venire contra factum proprium, do inciviliter agere e na invocação do tu quoque" PEREIRA, Caio Mário da Silva. Instituições de direito civil: introdução ao direito civil: teria geral de direito civil. Vol. I. $21^{a}$ Ed. Rio de Janeiro: Editora Forense, 2005, p. 502.

225 "Proibição do venire contra factum proprium, que veda que a conduta da parte entre em contradição com conduta anterior, do inciviliter agere, que proíbe comportamentos que violem o princípio da dignidade humana, e da tu quoque, que é uma invocação de uma cláusula ou regra que a própria parte já tenha violado". PEREIRA, Caio Mário da Silva. Instituições de direito civil: contratos, declaração unilateral de vontade, responsabilidade civil. Vol. III. 12 $2^{\mathrm{a}}$ Ed. Rio de Janeiro: Editora Forense, 2006, p. 21.

226 "A exceptio doli é conceituada como sendo a defesa do réu contra ações dolosas, contrárias à boa-fé. Aqui a boa-fé é utilizada como defesa, tendo uma importante função reativa [...] A exceção mais conhecida no Direito Civil brasileiro é aquela constante no art. 476 do Código Civil, a exceptio non adimpleti contractus, pela qual ninguém pode exigir que uma parte cumpra com a sua obrigação se primeiro não cumprir com a própria". "[duty to mitigate the loss] Trata-se do dever imposto ao credor de mitigar suas perdas, ou seja, o próprio prejuízo. Sobre essa premissa foi aprovado o Enunciado n. 169 CJF/STJ na III Jornada de Direito Civil, pelo qual 'O princípio da boa-fé objetiva deve levar o credor a evitar o agravamento do próprio prejuízo"”. TARTUCE, Flávio. Manual de direito civil. $2^{a}$ Ed. São Paulo: Editora Método, 2012, p. 547 e 551. 


\subsubsection{CARACTERÍSTICAS CONSENSUAIS}

Os instrumentos existentes para a solução de conflitos apresentam-se de forma diversificada: é possível negociar, demandar judicialmente, declarar guerra, entre outros tantos meios.

Acrescenta-se a isso ainda a possibilidade de serem criados novos mecanismos, fruto da combinação dos existentes ou, ao menos, derivados das formas base de solução de conflito. $^{227}$

Essa multiplicidade, todavia, deve ser pensada e utilizada tendo como base o entendimento de que existem instrumentos mais ou menos adequados para estes ou aqueles conflitos. $^{228}$

Por exemplo, o jogo de dados não é instrumento adequado para a definição do sujeito que terá a guarda de uma criança, por mais que os interessados consintam com estas regras. Por outro lado, vias consensuais tendem a ser adequados meios de tratamentos de conflitos entre sujeitos membros de uma unidade social de convívio cotidiano.

Cada mecanismo apresenta o seu próprio conjunto de características. É a partir da relação destas características com as do conflito, objeto de tratamento, que o grau de adequação do instrumento de solução de conflito é estabelecido.

\footnotetext{
${ }^{227}$ INTERESSE, REGRA E PODER: BASES DA SOLUÇÃO DE CONFLITOS, p. 37.

228 "Each process had its uses, each its distinctive advantages and disadvantages, and each was both structured by and, in turn, helped to structure the legal environment or culture from where it came. There were consequences to process choices-different processes both reflected and produced different rules and normative standards, but it could not be said that anyone process was perfect or appropriate for all kinds of matters (even in the delimited field of commercial law). Like her successors in the Legal Process school, Mentschikoff (and Fuller, as influenced by his Legal Process colleagues) could see the importance and significance of institutional variability and legitimacy in process". MEADOW, Carrie Menkel. Mothers and Fathers of Invention: The Intellectual Founders of ADR. Ohio: Ohio State Journal on Dispute Resolution, 2000 , p. 25.
} 
Considerando o objeto estudado e suas limitações, optou-se por enumerar e analisar as características dos mecanismos consensuais como gênero, não se pretendendo abarcar os detalhes e as diferenças de cada uma das suas espécies.

Dando início à análise das características, tem-se que, nos mecanismos consensuais, a tarefa de solucionar o conflito, ao não haver a substituição dos sujeitos pelo Estado ou por um terceiro, recai, juntamente com seus bônus e seus ônus, sobre as próprias partes. Dá-se a elas o poder $^{229}$ e a responsabilidade de gerir suas próprias vidas ${ }^{230}$ e, consequentemente, seus próprios conflitos.

Dessa forma, são os indivíduos em conflitos os responsáveis pela construção da solução, o que os torna seus autores.

Esta autoria dá origem a dois efeitos complementares. O primeiro, estabelece uma natural e positiva relação psicológica entre o autor e sua obra, no caso, entre as partes e a solução. O segundo, por seu turno, afasta a carga subjetiva negativa que uma decisão imposta por um terceiro possa vir a ter, ou seja, afasta o natural inconformismo humano que se apresenta principalmente frente a ordens divergentes aos interesses subjetivos. A solução é das partes e para as partes, não é algo coercitivo, que constrangerá o perdedor, que, por sua vez, evitará cumprir ou o fará de mal grado.

Por ser de autoria dos sujeitos do conflito, a solução tende a ser integrativa, apresentando consonância com os interesses deles, constituindo uma dinâmica "ganha-

\footnotetext{
${ }^{229}$ Ao se dar aos sujeitos poder de autogestão, constitui-se o fenômeno do enpoderamento. "Ao resolver os seus conflitos sem o auxílio do Judiciário, a comunidade torna-se menos dependente do assistencialismo estatal, aumenta sua coesão interna e promove o empoderamento de seus membros, pela noção de que eles mesmos podem resolver seus próprios conflitos. A pacificação social, uma das principais finalidades do Estado, é então exercida diretamente pelos cidadãos. Essa prática representa a possibilidade do exercício direto da cidadania, uma vez que garante aos membros da comunidade o direito de acesso à justiça ao mesmo tempo em que enseja o desempenho de seus deveres como cidadãos". VEDANA, Vilson Marcelo Malchow. O perfil da mediação comunitária: Acesso à Justiça e o empoderamento da comunidade. In AZEVEDO, André Gomma de (org.). Estudos em arbitragem, mediação e negociação. Vol. 2. Brasília: Brasília Jurídica, 2003, p. 264.

${ }^{230}$ Quanto à transferência de responsabilidade de gestão de conflitos para os próprios sujeitos, José Ignácio Botelho Mesquita entende que a aplicação de mecanismos consensuais dentro do sistema judiciário representa "um custo institucional muito alto, porque transfere para elas a responsabilidade pela solução do litígio, o que é particularmente grave em matéria penal, pois faz a vítima responsável pelo destino do acusado". MESQUITA, José Ignácio Botelho de. As novas tendências do Direito Processual: uma contribuição para seu reexame, p. 30.
} 
ganha" ${ }^{231}$ Isso culmina na maior probabilidade de cumprimento voluntário do acordado e, assim, maior efetividade do sistema.

A integração, todavia, não é uma qualidade exclusiva da solução, já que se apresenta também ao longo do procedimento. Isto porque o gradual processo de construção da solução ocorre, em regra, por meio da comunicação colaborativa e eficiente das partes. Esta dinâmica propicia a autorreflexão, bem como a descoberta e compreensão dos interesses em conflito, próprios e alheios, buscando integrá-los ou compatibilizá-los. ${ }^{232}$

Ademais, com estas características, isto é, consumação não instantânea e comunicação colaborativa, abre-se a possibilidade para que a mera tentativa de composição por si só já seja benéfica às partes, ainda que não se alcance a solução.

Valendo-se de técnicas alegóricas, observa-se que, a princípio, por mais que não se chegue ao destino final, o simples percorrer o caminho das vias consensuais traz ganhos aos sujeitos.

As tratativas consensuais, em regra, dão ensejo à comunicação e à aproximação das partes, mostrando-se produtivas e positivas e com o condão de restaurar, preservar ou intensificar o vínculo entre os indivíduos. ${ }^{233}$

${ }^{231}$ Em análise crítica à terminologia "ganha-ganha", Carrie Menkel Meadow, entende que esta terminologia pode ser inapropriada, já que nem sempre as duas partes ganham algo: "This seems an appropriate time for me to say why "win-win" is not how I would describe negotiation or conflict resolution. In many disputes, and most legal conflicts it will be impossible for both (or all) parties actually to "win" something. Consider the criminal defendant who may bargain for a "better" deal (less incarceration), but who will still be imprisoned. We aim for solutions that are "better than" some other baseline (an inferior process or a more limited scope of possible remedies) so we can improve on what might otherwise be possible. That does not necessarily mean that all parties will "win" something. So, I prefer to stay away from the "win-win" language as much as I do not like "win-lose" either. We are just trying to avoid "lose-lose" (negative sum games) outcomes as much as possible". MEADOW, Carrie Menkel. Mothers and Fathers of Invention: The Intellectual Founders of ADR. Ohio: Ohio State Journal on Dispute Resolution, 2000, p. 31.

232 "No modelo consensual, busca-se o "ganha-ganha", de modo que os próprios envolvidos sejam aptos a se compor e alcançar uma situação mais favorável em relação aos seus interesses, por intermédio de conversações e debates [...] o conflito é visto como uma forma de crescimento individual; com a oportunidade do diálogo e a autorreflexão das partes ambas são vencedoras". TARTUCE, Fernanda. Mediação nos conflitos civis. São Paulo: Editora Método, 2008, p. 107.

233 "Especificamente com referência a mediação, diversas abordagens são possíveis, mas a adotada no sistema brasileiro está voltada à transformação relacional dos envolvidos no conflito. O método é enfatizado pela possibilidade de reconstruir laços rompidos, a partir da comunicação e da reflexão experiência conflitiva, de modo que possam não apenas administrar o conflito presente, mas também conflitos futuros. Nesse sentido, o impasse se humanizaria devido à conscientização dos envolvidos pela existência de mútuos interesses e sentimentos em especial a dimensão transformadora da pessoa". SILVA, Érica Barbosa e. A efetividade da prestação jurisdicional civil a partir da conciliação. Orientador: Prof. Dr. Kazuo Watanabe. 
Com este beneficiamento e redirecionamento do liame intersubjetivo, facilitase, de forma global, a comunicação entre os sujeitos. Isso significa que haverá maior facilidade para, por exemplo, retomar tratativas interrompidas ou mesmo para tratar de outras questões, sejam pretéritas, contemporâneas ou futuras. ${ }^{234}$

Dessa forma, conforme os pensamentos de Mary Parker Follet, as vias consensuais têm o condão tirar proveito de recursos negativos, como o conflito, e, por meio de sua superação, transformá-los em produtos positivos. ${ }^{235}$

Deve-se notar, ainda, que gerir o próprio conflito é mais amplo do que apenas solucioná-lo. Nos meios consensuais, em regra, as partes podem também decidir as normas procedimentais, ${ }^{236}$ bem como as materiais que basearão as tratativas. Estes poderes vão ao encontro da adoção ou, ainda, da criação do mecanismo mais adequado para o conflito em tela. Com estas considerações, é oportuno relembrar a compatibilidade das vias consensuais com todas as três formas básicas de solução de conflito: interesse, regra e poder. $^{237}$

As tratativas consensuais, em regra, dão-se pessoal e oralmente, possibilitando a concentração de atos. Estas características, bem como a maior propensão à efetivação voluntária do acordo, como já analisado, permitem aos mecanismos consensuais que sejam céleres.

Entre as regras procedimentais, pode também estar presente o sigilo. As tratativas costumam estar protegidas por ele. Visa-se com isso, quebrar barreiras à

Tese de doutorado apresentada na Faculdade de Direito da Universidade de São Paulo. São Paulo: 2012, p. 147.

234 “o administrador do impasse deve expandir seus horizontes, pensando não só em compor as partes naquela controvérsia específica, mas também em prevenir futuras querelas pelo restabelecimento de uma comunicação eficiente entre partes que se compreendem e respeitam". TARTUCE, Fernanda. Mediação nos conflitos civis. São Paulo: Editora Método, 2008, p. 109.

${ }^{235}$ FOLLETT, Mary Parker. Prophet of management: a celebration of writings from the 1920s. Beard Books, 1996, p. 67.

${ }^{236}$ Conforme SILVA, Érica Barbosa e. A efetividade da prestação jurisdicional civil a partir da conciliação. Orientador: Prof. Dr. Kazuo Watanabe. Tese de doutorado apresentada na Faculdade de Direito da Universidade de São Paulo. São Paulo: 2012, p. 148.

${ }^{237}$ INTERESSE, REGRA E PODER: BASES DA SOLUÇÃO DE CONFLITOS, p. 37. 
comunicação, favorecendo-a. Sem o temor de que o externado seja exposto a terceiros, os sujeitos sentem maior liberdade, segurança e conforto para se expressar. ${ }^{238}$

Dessa forma, o sigilo também tende a potencializar uma das características das vias consensuais, que é o seu contato direto com as emoções.

As emoções geram conflitos, assim como conflitos geram emoções. ${ }^{239}$ Dessa forma, por mais que as emoções sejam aspectos inerentes aos conflitos, existem mecanismo que tendem a distanciar-se delas ou ainda a desconsiderá-las por meios de suas peças processuais e formalidades. As vias consensuais, por outro lado, estão propensas a ter direito contato com elas. Isso ocorre em decorrência da própria dinâmica do mecanismo, com sua pessoalidade e oralidade.

É possível que os interesses venham inundados em emoção. Seriam livres de emoções os interesses de um pai em relação ao suposto responsável pela morte de seu filho ou familiares de vítimas de acidentes frente ao representante do responsável pela indenização nas tratativas, que é, muitas vezes, a pessoa mais próxima do causador ou do suposto causador da tragédia que terão contato?

Adiciona-se a isso a capacidade das emoções de desencadear a escalada e o acirramento da disputa, tornando-se um desafio para os mecanismos consensuais. ${ }^{240}$

Desconsiderá-las pode não ser a medida mais adequada. Entre as possíveis técnicas para lidar com as emoções, está a de ventilá-las. A aplicação desta técnica deve ser aproveitada como uma oportunidade para que as partes exponham, juntamente com

\footnotetext{
${ }^{238}$ Conforme SILVA, Érica Barbosa e. A efetividade da prestação jurisdicional civil a partir da conciliação. Orientador: Prof. Dr. Kazuo Watanabe. Tese de doutorado apresentada na Faculdade de Direito da Universidade de São Paulo. São Paulo: 2012, p. 146.

${ }^{239}$ Conforme URY, William L.; BRETT, Jeanne M.; GOLDBERG, Stephen B. Getting disputes resolved: designing systems to cut the cost of conflict. $1^{\text {a }}$ Ed. São Francisco: Jossey-Bass Publishers, 1988, p. 6.

240 "Se as partes derivaram para violência exacerbada e nela insistem, não há como protagonizar tentativas de consenso enquanto as agressões persistirem. Afinal, para que o consentimento genuíno possa ser formado e externado, a técnica exige respeito e possibilidade de comunicação entre as partes sem prejuízo de sua própria saúde e da segurança do mediador". TARTUCE, Fernanda. Mediação extrajudicial e indenização por acidente aéreo: relato de uma experiência brasileira. In Lex Humana, v. 4, n. 1, 2012, p. 266.
} 
seus sentimentos, seus interesses. ${ }^{241}$ Paralelamente, a apresentação das emoções pode ser compreendida como uma demonstração de confiança, beneficiando a comunicação.

Ademais, essa técnica também tende a diminuir a latência de emoções negativas, como hostilidade, raiva, ressentimento e frustração. Ao ventilar seus sentimentos, o sujeito também agrega informações às tratativas, que podem ser aplicadas para guiar condutas, como um pedido de desculpas, e aproximar as partes da composição do conflito.

Outra peculiaridade das vias consensuais é a maior maleabilidade dos limites do objeto conflituoso. De forma geral, nada impede que as partes tragam à discussão e ao acordo questões anexas ou mesmo diversas das que deram origem à tentativa de composição.

Isso é possível por decorrência da autonomia privada, especificamente da autogestão de conflitos e da natureza consensual da composição. Por ser a solução fruto da comunhão de vontades, não compele as partes, nem viola suas liberdades ou interesses. Devido a isso, não há por que ser rígido no saneamento das tratativas, nem na fixação e delimitação das questões controvertidas.

A adstrição do objeto a ser tratado pode revelar-se um equivoco, quando se busca tratar efetiva e plenamente um conflito interpessoal. A maior flexibilidade na delimitação do objeto conflituoso permite que as partes ajustem-no, aumentando, diminuindo ou, até mesmo, alterando-o por completo. Assim, evita-se que as tratativas versem apenas sobre uma parcela do conflito, não permitindo seu tratamento global, ou mesmo sobre objeto diverso do real. ${ }^{242}$

Esta incongruência entre os objetos, ou seja, entre o conflito apresentado para tratamento e o conflito real, pode ser decorrência da limitação da ciência ou da

\footnotetext{
${ }^{241}$ Conforme URY, William L.; BRETT, Jeanne M.; GOLDBERG, Stephen B. Getting disputes resolved: designing systems to cut the cost of conflict. $1^{\text {a }}$ Ed. São Francisco: Jossey-Bass Publishers, 1988, p. 6.

${ }^{242}$ "Só as técnicas de um modelo consensual [...] possibilitam a identificação diferenciada do "conflito processado' e do 'conflito real' [...] haverá o conhecimento global da causa, a resolução integral do conflito, preservado o relacionamento entre os litigantes". BACELLAR, Roberto Portugal. A mediação no contexto dos modelos consensuais de resolução de conflito. In: Revista de Processo, São Paulo, n. 95, p. 122-134, jul.set. 1999.
} 
compreensão do conflito pelas partes. Isto é, eventuais disputas podem ser apenas um pequeno desdobramento de uma conjuntura conflituosa mais ampla e complexa, ainda não conhecida ou compreendida pelas partes.

Há ainda a propensão dos sujeitos do conflito, por natural ímpeto de defesa, a trazer às tratativas apenas alegações que entendem favoráveis aos seus interesses. Com isso, a realidade que chega às tratativas ou, considerando um mecanismo adjudicatório, ao julgador, tende a ser incompleta e, eventualmente, distorcida pela parcialidade dos polos. $^{243}$

Essas circunstâncias devem ser consideradas uma vez que acarretam dificuldades a uma adequada pacificação do conflito. Por outro lado, a flexibilidade do objeto pode mitigar estes efeitos negativos.

A máxima "o que não está nos autos, não está no mundo", apesar de ser uma ficção, ${ }^{244}$ por razões pragmáticas, é empregada em mecanismos adjudicatórios. Contudo, eventual discrepância entre a lide jurídica ${ }^{245}$ e a lide sociológica e o tratamento de apenas uma delas tende a não ser uma via efetiva à pacificação e, dessa forma, inadequada.

Conforme a compatibilidade dos meios consensuais com as três formas básicas de solução de conflito, a princípio, são possíveis mecanismos baseados predominantemente em interesse, a despeito do império das leis. ${ }^{246}$ Essa natureza pode se mostrar adequada

\footnotetext{
${ }^{243}$ Essa tendência, apesar de ser observada com maior facilidade nos mecanismos adjudicatórios, não está afastada das vias consensuais. "Ao demandar em juízo, as partes muitas vezes omitem certos aspectos fáticos relevantes, levando ao conhecimento do magistrado apenas uma fatia da realidade verificada. A outra parte, por sua vez, pode incorrer na mesma conduta e apenas apresentar fatos que repute favorável à sua tese. A situação do magistrado, assim, fica limitada a um panorama deliberadamente recortado pelas partes, o que pode gerar intensas dificuldades para a reconstituição histórica dos elementos relevantes e a dedução do que é realmente justo". TARTUCE, Fernanda. Mediação nos conflitos civis. São Paulo: Editora Método, 2008, p. 109.

${ }^{244}$ Diferentemente da presunção, pela qual se tem como verdade algo que pode o ser ou não, pela ficção, tem-se como verdadeiro algo que se sabe falso. Os autos processuais não conseguem comportar toda a diversidade de aspectos de uma relação conflituosa e de seus sujeitos, até porque, nem todos os elementos da realidade são aptos à perfeita conversão a mídia ou a meio compatível com os autos. Além disso, os autos são apenas uma faceta e uma simplificação da complexidade da realidade.

${ }^{245}$ Conforme afirma Enrico Tullio Liebman, "o conflito de interesse não entra para o processo tal como se manifestou na vida real, mas só indiretamente, na feição e configuração que lhe deu o autor em seu pedido". LIEBMAN, Enrico Tullio. O despacho saneador e o julgamento do mérito. In Estudos sobre o processo civil brasileiro. $2^{\mathrm{a}}$ Ed. São Paulo: Bushatsky, 1976, p. 115.

${ }^{246}$ Essa análise crítica é feita tendo como base os entendimentos de José Ignácio Botelho de Mesquita: “A expectativa da parte que se julga lesada pela outra é a de que, recorrendo ao juiz, o Estado lhe dará razão, confirmando sua convicção no império do direito e, reforçando na parte contrária a consciência da
} 
principalmente nas hipóteses em que as normas, disponíveis, encontrem-se em incompatibilidade com os interesses e com a efetiva pacificação social. ${ }^{247}$

Paralelamente, o objeto livre ou com limites tênues possibilita o transpasse das posições, alcançando os interesses por de trás delas. Isso se dá em atividade complementar à busca do conflito real.

Esta característica, quando analisada em um contexto de desenho de sistema de solução de conflitos, ocorre de forma própria. Isso por que os sistemas têm limites e insumos pré-definidos. ${ }^{248}$ Apesar disso, é possível que não se percam os potenciais benefícios advindos desta característica, caso sejam estabelecidos limites amplos o bastante para abarcar todos os conflitos em abstratos dos sujeitos do sistema. Tendo como exemplo a indenização de acidentes aéreos, a finalidade "indenização dos danos causados pelo acidente" mostra-se suficientemente amplo para ter como objeto todos os possíveis conflitos e seus desdobramentos que tenham origem na relação entre o consumidor e a empresa aérea ou o responsável pelo pagamento da indenização.

Observam-se assim forças antagônicas: de um lado a redução do objeto, como consequência da personalização do sistema; de outro, a eventual ampliação do objeto em decorrência da maleabilidade característica dos mecanismos consensuais. Como ainda será analisado, a compatibilização destes fluxos e a definição do objeto fazem parte do processo de criação de um sistema de solução de conflito.

responsabilidade pelo cumprimento das próprias obrigações. Essa expectativa se frustra ao ver a parte que o juiz, sem lhe negar razão, insta a que ela abra mão de parte do seu direito em favor daquele que nenhum direito tem. A preferência estatal pela conciliação constitui um fator de enfraquecimento do direito, enquanto método para a solução dos conflitos intersubjetivos, porque abala a confiança no império da lei. Torna desconfiados os homens simples e mais confiados os aventureiros. Para cada processo a que põe fim, estimula o nascimento de outros tantos. Abala os alicerces da coesão social”. MESQUITA, José Ignácio Botelho de. As novas tendências do Direito Processual: uma contribuição para seu reexame. P. 30

${ }^{247} \mathrm{Da}$ mesma forma que o império da lei pode não corresponder ao justo, ao interesse das partes e à pacificação social, também é possível que se comprometa o justo em prol de valores como paz, harmonia ou, simplesmente, redução de processos em atraso. "Thus, where mediation is thought to be designed to provide flexible, future-oriented solutions, critics point out that in cases of divorce, wronged and financially less secure women may be manipulated to compromise and give up too much. Similarly, others have argued that without the protection of the "rule of law" and the formality of the courtroom, racial and ethnic minorities as well as the economically disadvantaged will be taken advantage of by the more contextually powerful within the informal settings of ADR. Though she is not the only one, Nader's political and anthropological critique has provided an important standard against which to measure whether justice is being compromised in the quest for other values, like peace, harmony, or simple caseload reduction". MEADOW, Carrie Menkel. Mothers and Fathers of Invention: The Intellectual Founders of ADR. Ohio: Ohio State Journal on Dispute Resolution, 2000, p. 12.

${ }^{248}$ Como é analisado em LIMITES, p. 128. 
Ao prosseguir com a análise das características, observa-se, nos mecanismos consensuais, o direito de retirada ou opt out. ${ }^{249}$

Os sujeitos do conflito, ao afastarem a tutela jurisdicional estatal em prol da adoção de um mecanismo consensual na tentativa de compor o conflito, sempre têm a possibilidade de abandonar, a qualquer tempo, as tratativas, isto é, têm opção de sair (opt out). Por mais que as partes se obriguem de comum acordo a adotarem o mecanismo e tentarem a composição, nunca estarão vinculados a atingir necessariamente a solução.

Obviamente, de forma geral, este consentimento pela adoção do mecanismo e pela tentativa, constitui uma obrigação que deve ser adimplida à luz da boa-fé objetiva. Ainda assim, atingir uma solução consensual nunca poderá ser uma obrigação, por entrar em contradição com a própria racionalidade do mecanismo.

Como será mais bem analisado em tópico futuro, ${ }^{250}$ essa prerrogativa acarreta ao mecanismo incerteza quanto à solução. Pela dependência do consenso, existe a possibilidade que não se chegue à composição. Assim, de forma diversa ao que ocorre nas vias adjudicatórias que, excluídas as hipóteses de não conhecimento do mérito por questões de admissibilidade, há certeza quanto à definição de uma solução e de um vencedor, pondo fim à demanda. ${ }^{251}$

Cabe ressaltar ainda que algumas dessas características das vias consensuais só serão alcançadas, em um ambiente ideal. Isso porque, em contextos conflituosos, em geral, há um alto grau de repulsa e animosidade entre os sujeitos. Isso tende a os afastar do estabelecimento de comunicações colaborativas ou do entendimento quanto à adequação do meio a ser empregado no tratamento da relação conflituosa.

\footnotetext{
249 A técnica do opt out também é aplicada, de forma semelhante, mas não idêntica, às class action americanas, conforme GRINOVER, Ada Pellegrini; BENJAMIN, Antonio Herman de Vasconcellos e; FINK, Daniel Roberto; FILOMENO, José Geraldo Brito; WATANABE, Kazuo; NERY JÚNIOR, Nelson; DENARI, Zelmo. Código brasileiro de defesa do consumidor: comentado pelos autores do anteprojeto. $9^{\text {a }}$ Ed. Rio de Janeiro: Forense Universitária, 2007, p. 765.

${ }^{250}$ Essas características e suas consequências serão objeto de estudo do tópico O PROBLEMA DA EFETIVIDADE DOS MECANISMOS CONSENSUAIS, p. 88.

${ }^{251}$ Em uma análise crítica, contudo, é possível questionar se, no caso concreto, a solução da demanda equivale à solução do conflito e ainda se o escopo da pacificação social foi alcançado.
} 
Dessa forma, existe a possibilidade de que uma ou ambas as partes façam proveito de “jogadas” idealmente indesejáveis, não colaborativas, como ameaças, pressões, blefes. $^{252}$

À luz da ótima de Pareto ${ }^{253}$ ou ainda da teoria dos jogos, ${ }^{254}$ as "jogadas"255 são calculadas e tomadas considerando as informações disponíveis, o que eventualmente inclui ciência de que não se tem todos os recursos informativos necessários para a escolha perfeita. Como em um jogo de cartas, no qual se conhece as cartas que se tem na própria mão, bem como todas as cartas do baralho que estão em jogo, mas desconhece-se especificamente e com certeza as cartas da mão do adversário e destas, quais usará.

Dessa forma, os indivíduos calculam estas circunstâncias e realizam suas “jogadas". Cada uma destas afeta o jogo de quem a fez, bem como o dos concorrentes. ${ }^{256}$

${ }^{252}$ Conforme SILVA, Érica Barbosa e. A efetividade da prestação jurisdicional civil a partir da conciliação. Orientador: Prof. Dr. Kazuo Watanabe. Tese de doutorado apresentada na Faculdade de Direito da Universidade de São Paulo. São Paulo: 2012, p. 148.

253 "For many proponents of ADR, however, the Fullerian purpose is not complexity or diversity of process, but better outcomes. As modem negotiation theorists urge 'win-win' solutions, 'expanding the pie, before dividing it' or 'creating value before claiming it', it is useful to recall one early father, far removed from the legal arena. Vilfredo Pareto, as an economist and sociologist, is responsible for what we now call 'paretooptimality', an outcome measurement which searches for the best possible outcome for parties along an axis of preferences, in which each party is made as well off as possible without further harm to the other party. Some processes may be preferred because of their tendency to produce more pareto-optimal solutions, as in 'strategic cooperation', as studied by game theorists and decision scientists, in information sharing and trades that are made possible, but the goal is a utilitarian one of making the parties as well off as possible without unnecessary harm to each other. This does raise issues, however, about possible harmful externalities 'exported' to others". MEADOW, Carrie Menkel. Mothers and Fathers of Invention: The Intellectual Founders of ADR. Ohio: Ohio State Journal on Dispute Resolution, 2000, p. 31.

${ }^{254}$ A teoria dos jogos foi apresentada pelo matemático John von Neumann e o economista Oskar Morgenstern na obra Theory of Games and Economic Behavior em 1944. NEUMANN, John von; MORGENSTERN, Oskar. Theory of Games and Economic Behavior. Princeton: Princeton University Press, 1944.

255 "the corresponding distinction should be made for the moves, which are the component elements of the game. A move is the occasion of a choice between various alternatives, to be made either by one of the players, or by some device subject to chance, under conditions precisely prescribed by the rules of the game. The move is nothing but this abstract 'occasion', with the attendant details of description - i.e. a component of the game. The specific alternative chosen in a concrete instance - i.e. in a concrete play - is the choice. Thus the moves are related to the choices in the same way as the game is to the play. The game consists of a sequence of moves, and the play of a sequence of choices". NEUMANN, John von; MORGENSTERN, Oskar. Theory of Games and Economic Behavior. Princeton: Princeton University Press, 1944, p. 49.

${ }^{256}$ Conforme SILVA, Érica Barbosa e. A efetividade da prestação jurisdicional civil a partir da conciliação. Orientador: Prof. Dr. Kazuo Watanabe. Tese de doutorado apresentada na Faculdade de Direito da Universidade de São Paulo. São Paulo: 2012, p. 103. 
Não se pode descartar a possibilidade de que, como fruto deste cálculo, o jogador chegue ao entendimento que a melhor conduta a se adotar tenha caráter não colaborativo.

Contudo, a oferta de recursos técnicos, como informação e capacitação, é um instrumento para aumentar a propensão das partes a adotarem comportamento integrativo e colaborativo. Ela evita, dessa forma, condutas estritamente adversariais, egoístas e maléficas ao tratamento consensual do conflito. ${ }^{257}$ Paralelamente, a oferta de recursos técnicos, especificamente informações quanto às características do sistema de solução de conflito e a como tirar o maior proveito dele, tende a aproximar às partes dos contextos ideais. A disponibilização destes recursos visa mitigar comportamentos e sentimentos adversarias, enaltecer os benefícios da pacificação e apresentar informações sobre o mecanismo e sua boa aplicação.

Por fim, passa-se a analisar a vulnerabilidade dessa espécie de mecanismo à “disparidade de armas".

Cada sujeito tem o seu conjunto de recursos e, a princípio, dispõe-se destes de maneira a maximizar ganhos e reduzir perdas. A distribuição destes recursos, todavia, não se dá de forma homogênea entre os indivíduos.

Segundo Owen Fiss, a aplicação destes recursos influencia o consenso, ${ }^{258}$ tanto em relação à sua existência, como quanto ao seu conteúdo.

Considerando esta premissa, a desigualdade de recursos entre as partes pode culminar, por exemplo, em pressões ilegítimas e, dessa forma, conduzir para um consentimento viciado, em desacordo com o interesse ou, ainda, falso. ${ }^{259}$

\footnotetext{
${ }^{257}$ A cooperação muitas vezes pode ter fundamento não a confiança entre as partes, mas sim com base na duração da relação e condições que propicie ganhos mútuos. "The foundation of cooperation is not really trust, but the durability of the relationship. When the conditions are right, the players can come to cooperate with each other through trial-and-error learning about possibilities for mutual rewards, through imitation of other successful players, or even through a blind process of selection of the more successful strategies with a weeding out of the less successful ones. Whether the players trust each other or not is less important in the long run than whether the conditions are ripe for them to build a stable pattern of cooperation with each other". AXELROD, Robert. The Evolution of Cooperation. New York: Basic Books, 1984, p. 6. Disponível em http://www-ee.stanford.edu/ hellman/Breakthrough/book/pdfs/axelrod.pdf.

258 "o acordo é também um produto dos recursos de que dispõem cada uma das partes para financiar o processo judicial, sendo certo que tais recursos são, frequentemente, distribuídos de maneira desigual". FISS, Owen. Um novo processo civil. São Paulo: RT, 2004, p. 124.
} 
Contudo, esse não é um desafio exclusivo das vias consensuais. O desiquilíbrio entre as partes tem o condão de distorcer qualquer relação que exista entre elas, inclusive as existentes no processo judicial. Por mais que não se trate de uma competição que busque verificar quem tem mais recursos, a parte que os tiver em maior quantidade poderá contratar melhores advogados, mais aptos a empregar as técnicas processuais mais adequadas, resultando em uma apresentação de pretensões ou de defesas de melhor qualidade, assim como alcançar as últimas instâncias e esgotar as medidas cabíveis. ${ }^{260}$

Owen Fiss, ao mencionar a disparidade de recursos, não se refere ao gênero destes, mas sim, à espécie dos recursos financeiros. Contudo, por mais que a restrição à espécie simplifique a análise do balanço de recursos entre as partes, a realidade mostra-se mais complexa, acrescentando ao estudo outras espécies, como recursos técnicos, informação, etc.

Ainda que sejam considerados apenas os recursos financeiros, é improvável que sejam observadas isonomias absolutas no plano fático. ${ }^{261}$ Ao acrescentar outras espécies de recurso à comparação, esta isonomia torna-se ainda mais improvável.

Pela complexidade e diversidade dos indivíduos, é natural que não se encontrem indivíduos em igualdade absoluta. Não aceitar relações entre desiguais inviabilizaria qualquer forma de relação interpessoal. ${ }^{262}$

259 “Quando a autocomposição é imposta, perde sua legitimidade, visto que as partes, muitas vezes, não são propriamente estimuladas a compor seus conflitos, mas, sim, coagidas a tanto. Tal conduta, que pode ser denominada 'pseudo-autocomposição', é altamente criticável”. TARTUCE, Fernanda. Mediação nos conflitos civis. São Paulo: Editora Método, 2008, p. 113.

260 "Naturalmente, desequilíbrios de poder também podem distorcer o julgamento: os recursos de que dispõe a parte influenciam na qualidade da apresentação de sua pretensão, a qual, de sua feita, tem grande relevância para a definição de quem é o vencedor e dos termos da vitória”. FISS, Owen. Um novo processo civil. São Paulo: RT, 2004, p. 126.

261 Mauro Cappelletti e Bryant Garth colocam em duvida o entendimento da igualdade entre as partes: "o modelo frequentemente irreal de duas (ou mais) partes em igualdades de condições perante a corte, limitadas apenas pelos argumentos jurídicos que os experientes advogados possam alinhar", "Essa perfeita igualdade, naturalmente, é utópica. As diferenças entre as partes não podem jamais ser completamente erradicadas". CAPPELLETTI, Mauro; GARTH, Bryant. Acesso à justiça. Tradução Ellen Gracie Northfleet. Porto Alegre: Sergio Antonio Fabris Editor, 2002, p. 12 e 15.

262 Considerando a disparidade em relação aos recursos técnicos, Fernanda Tartuce afirma: "Existindo disparidade insuperável entre as partes em termos de conhecimento sobre seus direitos e orientação técnica sobre como se proteger, a mediação não se revela adequada. Assim, se uma parte não tem conhecimentos relevantes tem pouco (ou nenhum) poder sobre o outro contentor e está sem assistência jurídica, a situação de desiquilíbrio entre os mediandos pode comprometer a formação de um consentimento genuíno e a celebração 
Essa disparidade variará de caso a caso. Surge, dessa forma, nesta premissa de desiquilíbrio, o desafio de diferenciar um consentimento viciado, não genuíno, de um que seja compatível com os interesses do polo mais fraco, fruto de uma "jogada" voluntária, escolha do sujeito considerando as suas características e as da parte contrária. Assim, o que deve ser mitigado são os desequilíbrios excessivos que tendam a distorcer o consenso.

Como instrumento para tanto, considerando o DSD, devem ser incorporadas ao desenho, por exemplo, a técnica dos parâmetros referenciais, da assistência de terceiro imparcial e da análise neutra de terceiro, que serão analisadas adiante neste estudo. ${ }^{263}$

Após análise das características, novamente, reafirma-se que os meios consensuais não serão sempre adequados. ${ }^{264}$ Esta avaliação deverá ser realizada, preferencialmente em concreto, caso a caso, com base nas características do conflito e do mecanismo. Essa modalidade de instrumento mostra-se inadequada, por exemplo, no controle de constitucionalidade ou na criação de precedentes. Quanto a esses casos levantados, características como a da publicidade, da construção de precedentes e da possibilidade de causar efeito sobre um grande número de pessoas, tornam a adjudicação estatal adequada. $^{265}$

O sigilo, ilustrativamente, é adequado para conflitos de interesses estritamente ou preponderantemente privados, como tende a ocorrer entre empresas ou entre familiares.

de um acordo equânime e satisfatório". TARTUCE, Fernanda. Mediação extrajudicial e indenização por acidente aéreo: relato de uma experiência brasileira. In Lex Humana, v. 4, n. 1, 2012, p. 267.

${ }^{263}$ Essas e outras técnicas serão analisadas em TÉCNICAS, p. 139.

${ }^{264}$ Cathy A. Costantino e Christina S. Merchant, em um capítulo intitulado "The dark side of ADR", no contexto norte americano, levantam questionamentos quanto à adequação dos ADRs, considerando seus altos custos ou ainda a possibilidade dessas vias serem usadas ara acobertar violações sistêmicas e respetivas dentro das organizações. Por outro lado, colocam em dúvida se os ADRs são realmente inapropriados e não devem ser adotados para tratamento de violência doméstica, ainda que a parte mais fraca esteja assistida, casos de violação de diretos civis, discriminação sexual e questões ambientais. Por fim, não afastam a possibilidade dos ADRs serem inapropriados: "use of ADR may not only be inappropriate but also unethical under OD [organization development] as well as ADR values, practices, and principles of client selfdetermination". COSTANTINO, Cathy A.; MERCHANT, Christina Sickles. Designing conflict management systems. $1^{a}$ Ed. São Francisco: Jossey-Bass, 1996, p. 44.

265 "Com relação à adjudicação judicial, é preciso frisar que se trata de meio adequado para realizar o controle de constitucionalidade, dando significado aos valores públicos e conferindo sentido concreto aos dispositivos constitucionais. Pode ainda realizar controle de politicas públicas e criar precedentes. Nesses casos, a publicidade é uma característica fundamental do método, sobretudo considerando os desdobramentos sociais de determinados processos que guardam relevância em questões polêmicas e afetam grande numero de pessoas". SILVA, Érica Barbosa e. A efetividade da prestação jurisdicional civil a partir da conciliação. Orientador: Prof. Dr. Kazuo Watanabe. Tese de doutorado apresentada na Faculdade de Direito da Universidade de São Paulo. São Paulo: 2012, p. 150. 
Contudo, mostra-se inadequado para questões com interesse público, como um compromisso de ajustamento de conduta.

\subsubsection{OS DOIS CONSENSOS}

Os mecanismos consensuais desenvolvem-se sobre inúmeros e sucessivos consensos. São constantes afirmações, reafirmações, revalidações das tratativas que são dadas pelos sujeitos de forma expressa ou tácita. ${ }^{266}$

A despeito desta multiplicidade, é possível a aplicação de critérios para a organização destes consensos em classes. Considerando o objeto do presente estudo, especificamente, o desenho de sistemas de solução de conflito (DSD), ${ }^{267}$ optou-se por classificá-los em materiais e formais. Os primeiros versam sobre a matéria conflituosa e os segundos, por sua vez, sobre a forma instrumental que será adotada, ou seja, sobre o mecanismo de solução de conflito. Como será demonstrado, essa separação auxiliará o entendimento da dinâmica do DSD, tanto em relação à criação do instrumento, como ao tratamento do conflito.

A aceitação, a cada rodada ou a cada proposta, em negociar e continuar negociando, bem como de analisar as proposições da outra parte são exemplos de consensos de cunho material. Somam-se a estes, os referentes à composição de parcelas do conflito e o consenso final, que comporá as parcelas remanescentes e finais do conflito.

Considerando o método do DSD, os consensos quanto à forma podem ocorrer tanto na fase de criação do sistema de solução de conflito personalizado, como ao longo do tratamento do conflito, com a aceitação ou definição de regras procedimentais e de comunicação.

266 Os mencionados consensos tácitos podem, muitas vezes, configurar consentimentos, tolerância a manifestação alheia. Por mais que eventualmente discorde com o conteúdo da comunicação de seu interlocutor, tolera-a e consente em permanecer nas tratativas.

${ }^{267}$ DSD - DISPUTE SYSTEM DESIGN, p. 90. 
Eventualmente, os consensos, tanto os materiais, como os formais, podem ter seu conteúdo sugerido, integral ou parcialmente, por um terceiro imparcial, como ocorre na conciliação.

Essa dinâmica de múltiplos consensos existe pela própria natureza dos meios consensuais. Por serem baseados na autonomia privada, autodeterminação, são de livre entrada e de livre saída. Com a prerrogativa de desistir livremente das tratativas, pode-se entender que a permanência, a cada etapa ou nova proposição, como um novo consentimento. Ao permanecer, o sujeito renúncia ao seu direito de saída. Essa renúncia constitui um negócio jurídico, já que o agente persegue este determinado efeito jurídico. ${ }^{268}$

Dois destes consensos destacam-se por serem polos de concentração e, por isso, gerarem efeitos relevantes para o mecanismo, para as partes e para o conflito. São eles: as comunhões de vontade pela adoção do mecanismo consensual e pela composição do conflito. O primeiro, referente à criação e adoção do mecanismo, antecede o outro e concentra predominantemente consensos de cunho formal, enquanto o segundo concentra os efeitos de consensos predominantemente ${ }^{269}$ materiais.

O primeiro consenso é uma peculiaridade do DSD. Ele concentra os consensos formais alcançados ao longo das tratativas da fase de desenho do sistema.

O desenho se dá por meio de mecanismos consensuais que têm natureza autorreferente, já que são mecanismos que discutem o próprio mecanismo. ${ }^{270} \mathrm{O}$ objeto destas tratativas é a forma. Desse modo, o sistema de solução de conflito é desenhado a partir das contraposições e composições das partes. Como resultado, tem-se este primeiro consenso, que é a comunhão das partes quanto ao desenho e quanto à adoção do sistema desenhado, optando-se por afastar a faculdade de utilização do poder Judiciário.

\footnotetext{
${ }^{268}$ Difere-se, dessa forma, do ato jurídico em sentido estrito, uma vez que, apesar deste também ter entre seus elementos a manifestação de vontade, os efeitos jurídicos são gerados independentemente de serem perseguidos diretamente pelo agente. PEREIRA, Caio Mário da Silva. Instituições de direito civil: introdução ao direito civil, teria geral de direito civil. Vol. I. $21^{\text {a }}$ Ed. Rio de Janeiro: Editora Forense, 2005, p. 475.

${ }^{269}$ Utiliza-se o termo "predominantemente", pois nada impede que ao longo da tratativa de referentes à composição do conflito, os sujeitos também definam regras de comunicação ou quanto aos encontros, por exemplo.

270 "the process of dispute system design can be considered a kind of 'meta-mediation', a mediation about mediation and other processes of conflict management". COSTANTINO, Cathy A.; MERCHANT, Christina Sickles. Designing conflict management systems. $1^{\text {a }}$ Ed. São Francisco: Jossey-Bass, 1996, p. X.
} 
Esta primeira fase não tem como escopo primário a pacificação social, mas coaduna-se à finalidade do DSD de criação do sistema mais adequado de solução de conflito. $^{271}$

Qual será o critério para avaliar a legitimidade dos sujeitos para aderir ao sistema e por fim compor seu conflito? Quais serão os critérios de pagamento? Quem proverá os diferentes recursos necessários para a criação e manutenção do sistema, bem como para as indenizações? São questões como estas que deverão ser composta para que se tenha um sistema indenizatório, por exemplo.

Considerando as posições e os interesses e, ainda, o contexto conflituoso existente, é natural que haja divergências. Estas, todavia, precisam ser convertidas em convergências, tendo em vistas a natureza consensual da via, sob pena de se interromper a atividade de desenho.

Os sujeitos deste consenso podem não coincidir com os sujeitos do consenso referente à segunda área de concentração, que ainda será analisada. Esta não identidade não só é possível, como ela tende a ocorrer em conflitos que versem sobre interesses individuais homogêneos. ${ }^{272}$ A coletividade é representada por um ou mais sujeitos com poderes e legitimidade para tanto. Dessa forma, assim como ocorreu nos casos de acidentes aéreos que serão estudados, a coletividade tende a ser substituída por autoridades públicas e estruturas associativas privadas nas quais os indivíduos deste grupo organizaram-se. ${ }^{273}$

Eventual inadimplemento deste primeiro consenso pode ser objeto de tutela específica, de forma análoga ao que ocorre com a arbitragem. ${ }^{274}$ Contudo, diferentemente

\footnotetext{
${ }^{271}$ Como ainda será desenvolvido no tópico DSD - DISPUTE SYSTEM DESIGN, p. 90.

${ }^{272}$ Conforme analisado nos tópicos SOCIEDADE DE MASSA E SEUS CONFLITOS, p. 13, e INTERESSES INDIVIDUAIS HOMOGÊNEOS, p. 19.

${ }^{273}$ Por exemplo, no caso da Câmara de Indenização Voo 3054, os sujeitos deste primeiro consenso foram as autoridades integrantes do Sistema Nacional de Defesa do Consumidor (SNDC), em especifico, o Ministério Público do Estado de São Paulo (MP-SP), Defensoria Pública do Estado de São Paulo, Fundação PROCON do Estado de São Paulo e Secretaria de Direito Econômico (SDE) do Ministério da Justiça e as empresas responsáveis pelo pagamento das indenizações, TAM e suas seguradoras e ressegurados, representadas pela seguradora Unibanco AIG.

${ }^{274}$ Lei 9.307/96Art. $7^{\circ}$ Existindo cláusula compromissória e havendo resistência quanto à instituição da arbitragem, poderá a parte interessada requerer a citação da outra parte para comparecer em juízo a fím de lavrar-se o compromisso, designando o juiz audiência especial para tal fim.

$\S 1^{\circ} \mathrm{O}$ autor indicará, com precisão, o objeto da arbitragem, instruindo o pedido com o documento que contiver a cláusula compromissória.
} 
da possibilidade de substituição pelo magistrado da vontade da parte, dando início ao procedimento arbitral, que poderá correr à revelia da parte que resistiu, a obrigação de participar de tratativas consensuais e compor o conflito em um possível acordo é uma obrigação de fazer intuitu personae. ${ }^{275}$ Dessa forma, segundo artigo 247 do Código Civil, é conversível em perdas e danos caso haja recusa ao adimplemento.

Esta conversão não compartilha da mesma efetividade da tutela específica. Entretanto, entende-se que combater este inadimplemento com coerção também é inadequado. Isso porque, forçar alguém a participar de um mecanismo, com base consensual e no qual há o direito de retirada (opt out), constitui um contrassenso com a própria racionalidade da via. Obrigar os sujeitos a estabelecer comunicação e buscar o consenso, sem que elas desejem e consintam com isso, pode ser visto como algo patológico dentro da racionalidade de meios consensuais. Além disso, estar-se-ia obrigando o sujeito a sentar-se à mesa de negociação, porém, com o direito de retirar-se a qualquer tempo. ${ }^{276}$

Voltando-se para o segundo consenso, tem-se que ele é o marco da composição do conflito, sendo o ponto de concentração dos consensos predominantemente materiais e que se dão após o primeiro consenso, de cunho formal.

O segundo consenso é o acordo que normalmente vem em mente quando se pensa em mecanismos de solução de conflito, até porque, é o que compõe o conflito.

$\S 2^{\mathrm{o}}$ Comparecendo as partes à audiência, o juiz tentará, previamente, a conciliação acerca do litígio. Não obtendo sucesso, tentará o juiz conduzir as partes à celebração, de comum acordo, do compromisso arbitral. $\S 3^{\circ}$ Não concordando as partes sobre os termos do compromisso, decidirá o juiz, após ouvir o réu, sobre seu conteúdo, na própria audiência ou no prazo de dez dias, respeitadas as disposições da cláusula compromissória e atendendo ao disposto nos arts. 10 e $21, \S 2^{\circ}$, desta Lei.

$\S 4^{\circ}$ Se a cláusula compromissória nada dispuser sobre a nomeação de árbitros, caberá ao juiz, ouvidas as partes, estatuir a respeito, podendo nomear árbitro único para a solução do litígio.

$\S 5^{\circ} \mathrm{A}$ ausência do autor, sem justo motivo, à audiência designada para a lavratura do compromisso arbitral, importará a extinção do processo sem julgamento de mérito.

$\S 6^{\circ}$ Não comparecendo o réu à audiência, caberá ao juiz, ouvido o autor, estatuir a respeito do conteúdo do compromisso, nomeando árbitro único.

$\S 7^{\circ}$ A sentença que julgar procedente o pedido valerá como compromisso arbitral.

275 Obrigação intuitu personae é o mesmo que obrigação personalíssima. "Quando personalíssima, a obrigação vigora tão-somente entre as partes e extingue-se com elas”. Essa espécie de obrigação é contraída em razão das pessoa do devedor e/ou credor, não sendo possível que ninguém mais adimpla a obrigação no lugar desses. PEREIRA, Caio Mário da Silva. Instituições de direito civil: teoria geral das obrigações. Vol. II. $20^{\mathrm{a}}$ Ed. Rio de Janeiro: Editora Forense, 2005, p. 170.

276 "One can be required to participate in mediation, but one cannot be required to agree to the proposed settlement derived through the mediation process". COSTANTINO, Cathy A.; MERCHANT, Christina Sickles. Designing conflict management systems. $1^{a}$ Ed. São Francisco: Jossey-Bass, 1996, p. 39. 
Considerando o contexto de acesso à justiça e situações que envolvam interesses individuais homogêneos, os dois consensos também podem ser analisados sob outra perspectiva, a qual remete não ao objeto, material ou formal, mas sim, à forma de tutela, coletiva ou individual. ${ }^{277}$

No primeiro consenso, unem-se estes interesses pela sua origem comum e homogeneidade, tutelando-os coletivamente. Originam-se termos de acordo mais amplos, contudo, sem prejudicar ou esvaziar o tratamento das peculiaridades do conflito. Dá-se assim o consenso quanto à criação e adoção do instrumento de tratamento destes interesses individuais homogêneos.

Esta comunhão de vontades pode se formalizar em um compromisso de ajustamento de conduta, assim como ocorreu nos dois acidentes aéreos que serão analisados neste estudo. ${ }^{278}$

A teoria contratualista, que entende ter esse compromisso natureza de negócio jurídico bilateral e não ato administrativo unilateral, vai ao encontro do desenvolvido quanto à racionalidade dos mecanismos consensuais e à natureza jurídica do consenso.

No primeiro consenso, ao se fazer uso da técnica da representatividade extraordinária para tutelar coletivamente os interesses individuais homogêneos, deve-se estar atento à sua indisponibilidade. Isto, contudo, não impede que seja criado e adotado um mecanismo de solução de conflito, uma vez que não há prejuízo ao interesse, nem sua disposição.

O segundo consenso, por sua vez, seria resultado da tutela individual dos interesses. Nesta fase, cabe aos titulares dos direitos individualmente considerados entrarem em composição quanto à indenização.

277 Conforme analisado nos tópicos SOCIEDADE DE MASSA E SEUS CONFLITOS, p. 13, e INTERESSES INDIVIDUAIS HOMOGÊNEOS, p. 19.

278 "compromisso de ajustamento de conduta, passando a ser um instrumento de composição de controvérsias e estabilizador social a ser celebrado diretamente encontre a Administração e os interessados nas questões envolvendo direitos coletivos". FERNANDES, Rodrigo. Compromisso de ajustamento de conduta ambiental: fundamentos, natureza jurídica, limites e controle jurisdicional. Rio de Janeiro: Editora Renovar, 2008, p. 53. 


\subsubsection{O PROBLEMA DA EFETIVIDADE DOS MECANISMOS CONSENSUAIS}

Nos meios consensuais, não há uma solução imposta, que desagrada ao perdedor ou, eventualmente, até mesmo ao vencedor. Há sim uma solução cujas obrigações nela previstas foram acordas pelas partes, por livre consentimento, com direto atendimento de seus interesses. Assim, tem-se, como consequência lógica, o cumprimento da solução ou, ao menos, a maior probabilidade de adimplemento do que foi acordado. O que acarreta maior facilidade de se alcançar a tutela específica do direito ou do interesse em conflito. ${ }^{279}$

Tendo em vista estas características, pode-se chegar ao entendimento de que, em regra, tem-se uma solução efetiva.

Todavia, entre os desafios enfrentados pelos mecanismos consensuais está o problema da efetividade.

Por mais que entregue às partes o poder de se autodeterminar, de criar suas próprias soluções, com alto nível de satisfação pela compatibilidade com seus interesses, os meios consensuais dependem do consenso. Assim, caso haja a quebra da sequência de consensos por um dissenso, tem-se como implicação o fim das tratativas e a não composição do conflito.

Deve-se observar, entretanto, que o problema da efetividade em tela não se encontra na solução, mas sim na possibilidade de um não acordo e, dessa forma, do mecanismo não resolver o conflito. Ou seja, o problema da efetividade aqui discutido, não diz respeito à solução alcançada por meio dos mecanismos consensuais, mas sim, refere-se ao mecanismo em si. Ademais, considerando o DSD e seus dois consensos, como analisado no tópico anterior, constata-se que a problemática exposta quanto à efetividade refere-se à eventualidade, à falta de certeza quanto ao segundo consenso, que compõe o conflito, e não quanto ao primeiro, o qual estabelece o desenho do sistema e sua adoção.

\footnotetext{
${ }^{279}$ Defende-se que, por meio das vias consensuais, há maior facilidade para se alcançar a tutela, porque, de forma geral, a comunicação baseia-se na conciliação dos interesses. Dessa forma, caso se alcance a composição do conflito, dentro da racionalidade das vias consensuais, satisfez-se o exato interesse da parte.
} 
Contudo, por mais que seja corriqueira da práxis forense a utilização do termo “infrutífera” para qualificar a audiência de conciliação ou mediação sem acordo, entendese que esse não é adequado. Isto por que, não se pode pensar que o único fim das vias consensuais seja o acordo. Como já mencionado, ${ }^{280}$ a simples oportunidade de se estabelecer a comunicação entre as partes, de forma organizada, assistida ou não, gera benefícios para elas e para a busca de uma solução, por mais que esta não seja alcançada neste momento.

Essa incerteza quanto à resolução do conflito decorre do próprio fundamento destes mecanismos, o consenso. Como não há imposição de uma solução, não há como assegurar que se chegue ao fim do conflito. Essa dependência do consenso prejudica a efetividade das vias consensuais, apesar dos benefícios apontados anteriormente.

Por outro lado, é questionável se a proibição do non liquet, ${ }^{281}$ ou seja, a necessidade de decidir, efetivamente ponha fim aos conflitos tratados nas vias adjudicatórias. Apenas para citar dois exemplos, pode se pensar nos casos nos quais o autor e réu recorrem da sentença, evidenciando a insatisfação das partes, assim como na execução, cuja aplicação demonstra a insatisfação do condenado, ou mais, sua impossibilidade de arcar com as obrigações que lhe foram impostas pelo terceiro julgador.

Como foi visto, este último consenso pode não ser alcançado, restando o procedimento sem solução. Já quanto ao primeiro consenso, como analisado no tópico anterior, é possível o combate do seu inadimplemento com tutela específica, por mais que se entenda pela inadequação deste remédio, frente à natureza consensual do mecanismo que se busca instituir e ao direito de retirada que as partes têm.

Pela não desnaturação dos mecanismos consensuais, deve se conhecer essa peculiaridade quanto à efetividade e considerar tal característica quando da escolha do mecanismo mais adequado para solucionar determinado conflito.

280 Conforme analisado em RACIONALIDADE DOS MECANISMOS CONSENSUAIS, p. 61, e CARACTERÍSTICAS DOS MECANISMOS CONSENSUAIS, p. 69.

${ }^{281}$ Conforme artigo 126 do Código de Processo Civil: "O juiz não se exime de sentenciar ou despachar alegando lacuna ou obscuridade da lei. No julgamento da lide caber-lhe-á aplicar as normas legais; não as havendo, recorrerá à analogia, aos costumes e aos princípios gerais de direito". 
É possível mitigar este problema de efetividade dos mecanismos consensuais por meio da oferta de recursos informativos, como capacitação e motivação. Eles têm o condão de maximizar os benefícios do mecanismo, aumentando sua eficiência, efetividade e, dessa forma, sua adequação.

Tendo em vista a estrutura do DSD, estes recursos podem ser ofertados por meio de técnicas e procedimentos internos ao sistema, todavia não necessariamente durante a negociação. Pode-se pensar, por exemplo, em encontros informativos ou de capacitação.

Outra técnica aplicável é a previsão de um sistema escalonado, com a sucessão de mecanismos consensuais por adjudicatórios. Contudo, isso acarretaria alteração da racionalidade do sistema de solução de conflito, além de extrapolar os objetos deste estudo.

\section{DSD - DISPUTE SYSTEM DESIGN}

Ao longo deste estudo, foram apresentados conteúdos de forma a construir os alicerces para que a análise do desenho de sistema de solução de conflito (Dispute System Design - DSD) ocorresse dentro de um ambiente já contextualizado e com suas premissas teóricas desenvolvidas.

Com as reflexões propostas, recordou- $\mathrm{se}^{282}$ a natureza instrumental do processo. Este, como instrumento, deve primordialmente guiar ao seu fim maior, a pacificação social. ${ }^{283}$ Dessa forma, evita-se o processo no qual as formas reinam em detrimento de sua finalidade.

Ainda assim, apenas conceber, no plano das ideias, o processo como instrumento não é suficiente para que a pacificação social seja concretizada. Este escopo só é atingido, quando a racionalidade da instrumentalidade é trazia ao plano fático, à

\footnotetext{
${ }^{282}$ Utiliza-se o verbo "recordar", pois ao longo da história, é notória a oscilação do processo entre os formalismos e a instrumentalidade. Por mais que extrapole o objeto do presente estudo, aborda-se o tema no tópico INSTRUMENTALIDADE, p. 29.

${ }^{283}$ CINTRA, Antonio Carlos de Araújo; GRINOVER, Ada Pellegrini; DINAMARCO, Cândido Rangel. Teoria Geral do Processo. 22 ${ }^{\mathrm{a}}$ Ed. São Paulo: Malheiros Editores, 2006, p. 30.
} 
realidade. É necessário que essa mentalidade seja convertida em meios concretos e adequados de solução de conflitos, que consigam ofertar aos cidadãos, em tempo razoável, procedimentos e produtos satisfatórios, soluções efetivas, entre outros aspectos.

Como ainda será analisada, ${ }^{284}$ a qualidade "adequação" é resultante de uma análise de custo. Estes custos, todavia, devem ser entendidos de forma ampla, ultrapassando sua concepção financeira.

Considerando esse raciocínio, realizou-se um estudo quanto à adequação dos mecanismos de solução de conflito, tendo em vista as diferentes racionalidades das vias ${ }^{285}$ e a diversidade de tipos de questões conflituosas. ${ }^{286}$

Este momento histórico é também qualificado pela retomada de liberdades individuais voltadas à assegurar ${ }^{287}$ ao indivíduo a possibilidade de gerenciamento de seus próprios conflitos. Cabe destacar que estas liberdades abrangem não apenas a definição da solução, como também a forma de tratamento adotada.

Acrescem-se ainda a este panorama a dinâmica de tese e antítese estabelecida entre a massificação, ${ }^{288}$ e os novos movimentos humanos de exaltação das diferenças, do individual, do singular.

Dentro da perspectiva do direito processual, por meio do estudo deste confronto entre o padrão e as singularidades, verifica-se que o mecanismo padrão nem sempre consegue oferecer esse mencionado produto adequado. ${ }^{289}$ Por não atender, de

\footnotetext{
${ }^{284}$ Conforme tópico CUSTOS DO TRATAMENTO DO CONFLITO (COSTS OF DISPUTING), p. 114.

${ }^{285}$ Pretende-se com a expressão "racionalidades das vias" remeter principalmente aos meios consensuais e adjudicatório, que apresentam em seu ideário elementos diversos, apesar do fim comum de pacificação social.

${ }^{286}$ Como foi apresentado em RACIONALIDADE DOS MECANISMOS CONSENSUAIS, p. 61, este fenômeno de autonomia, designada como empoderamento, está presente, não só, na possibilidade de escolha de qual caminho será seguido para a solução do conflito, mas, principalmente, nas vias consensuais, nas quais, há a opção pelo mecanismo, como também, a construção da solução pelas partes do conflito.

${ }^{287}$ Excepcionalmente, existem limitações à essas liberdades, como a vedação, como regra, da autotutela.

${ }^{288}$ Conforme tópico SOCIEDADE DE MASSA E SEUS CONFLITOS, p. 13.

289 "O caráter transubstancial do processo, de atender indistintamente a um grande conjunto de tipos de situações controvertidas, pelo qual é tradicionalmente concebido, vem sendo colocada em xeque diante da crescente complexidade das situações fáticas e jurídicas da realidade contemporânea. A perda da capacidade do processo para responder a uma grande diversidade de situações, independentemente da matéria a que digam respeito, acaba por enfraquecer a qualidade da resposta processual". SALLES, Carlos Alberto de. Arbitragem em contratos administrativos. $1^{\text {a }}$ Ed. Rio de Janeiro: Editora Forense, 2011, p. 20.
} 
forma efetiva, às necessidades humanas, progressivamente mais complexas e diversificadas, não atinge seu escopo maior. Essa situação é análoga à proposição de Henry Ford $^{290}$ em relação aos seus automóveis: carros necessariamente pretos, como sugeriu, não conseguem satisfazer a todos os seus consumidores, apesar de colaborar com a atividade produtiva.

Por mais que seja simples constatar que o martelo não é a melhor ferramenta para serrar uma tábua, nem sempre é obvia tal relação de adequação quando se está perante relações humanas, complexas e invariavelmente conflituosas. A nova visão sobre os ADRs, como mecanismos adequados de solução de conflito, ${ }^{291}$ apesar de incipiente entre os processualistas, busca ponderar que nem sempre a via judicial será a mais adequada, assim como nem sempre mecanismos consensuais serão. ${ }^{292}$

É possível afirmar que o DSD busca elevar ao máximo a ideia de adequação presente nesse novo entendimento dos ADRs. Isso porque, ele vai além da utilização da ferramenta mais adequada entre as existentes dentro da "caixa de ferramentas". ${ }^{293}$ Tem uma perspectiva diferente, propõe que seja criada a ferramenta mais adequada para solução de determinado conflito. Este desenho é feito, tendo como base a análise das peculiaridades do conflito. Isto abrange não somente elementos objetivos, decorrente da matéria conflituosa, como também elementos subjetivos, ou seja, as características e interesses das partes envolvidas.

O Dispute System Design nasceu do movimento dos ADRs no final da década de 1980, quando especialistas começaram a utilizar seus conhecimentos para auxiliar clientes na composição de seus conflitos ${ }^{294}$ com base em uma nova forma de aplicação dos ${ }^{290}$ FORD, Henry. My life and work. New York: Cosimo, 2007, p. 72.
${ }^{291}$ MEIOS ADEQUADOS DE SOLUÇÃO DE CONFLITO, p. 51.
${ }^{292}$ "There must be a fit between the process and the problem”. COSTANTINO, Cathy A.; MERCHANT,
Christina Sickles. Designing conflict management systems. $1^{\text {a }}$ Ed. São Francisco: Jossey-Bass, 1996, p. 41.
Eventualmente, o fracasso decorrente da aplicação do ADR em um determinado conflito, pode não ser
consequência da adoção dos ADRs como gênero, mas sim, da falta de adequação da espécie do mecanismo
escolhido ou de seu desenho, por falha na observação dos princípios e técnicas do DSD.
${ }^{293}$ Conforme ilustração feita em ÁLVAREZ, Elena I.; HIGHTON, Gladys S.; JASSAN, Elías. Mediación y
Justicia. Buenos Aires: Depalma, 1996, p. 122
${ }_{294}$ Por um longo período nos anos 80 , a IBM e a Fujitsu, duas gigantes da computação, travaram centenas de
disputas nas quais a primeira acusava a segunda de violação de direitos autorais. Com o auxílio dos árbitros
Robert Mnookin e John Jones, as empresas chegaram a um consenso quanto a um mecanismo que permitia à
Fujitsu o exame e uso do software da IBM em troca de uma adequada remuneração. Além disso, ficou
estipulado que futuras disputas quanto ao uso deste software seriam resolvidas por um especialista (expert) 
mecanismos existentes. ${ }^{295}$ Visavam encorajar vias menos adversariais, de menor custo ${ }^{296} \mathrm{e}$ fundamentadas nos princípios e nas técnicas da negociação baseada em interesse, apresentada por Roger Fisher e William Ury na obra Getting to Yes de $1981 .^{297}$ Esses especialistas trabalharam separadamente em seus casos, buscando o instrumento mais adequado para solucionar os conflitos a eles apresentados. ${ }^{298}$

Dentro dessa lógica, pode-se conceituar o DSD como um ${ }^{299}$ método, baseado em princípios e técnicas, de customização de sistemas que possibilitem o procedimento e a solução mais adequada a um determinado conflito.

Destaca-se que, diferentemente das vias consensuais ou adjudicatórias, o DSD não tem natureza de mecanismo de solução de conflito. Ele é um método de criação de sistema de solução de conflito. Este sistema, produto desse método, por sua vez, é um mecanismo ou um conjunto de mecanismos dispostos de forma a propiciar o adequado processamento e solução do conflito. Reforça-se que o método do DSD e seu produto, o sistema de solução de conflito, não se confundem.

Sendo assim, o DSD não tem natureza de processo, nem tem como escopo primário a pacificação social, mas sim, apresenta como finalidade a criação do sistema capaz de solucionar adequadamente determinado conflito. Seu produto, no entanto, como mecanismo de solução de conflitos, tem natureza de processo.

Por meio de uma breve reflexão, pode-se chegar ao entendimento de que a constante busca por melhorias é um elemento intrínseco à natureza humana. Abstratamente, aprimoramentos são desenvolvidos com o intuito de se evitar custo. Por óbvio, esse raciocínio não se dá de forma idêntica em todos os indivíduos, mas,

neutro e que problemas quanto à remuneração seriam teriam suas soluções definidas pelos árbitros. URY, William L.; BRETT, Jeanne M.; GOLDBERG, Stephen B. Getting disputes resolved: designing systems to cut the cost of conflict. $1^{\text {a }}$ Ed. São Francisco: Jossey-Bass Publishers, 1988, p. xii.

${ }^{295}$ COSTANTINO, Cathy A.; MERCHANT, Christina Sickles. Designing conflict management systems. $1^{\mathrm{a}}$ Ed. São Francisco: Jossey-Bass, 1996, p. 44.

${ }^{296}$ Conforme tópico CUSTOS DO TRATAMENTO DO CONFLITO (COSTS OF DISPUTING), p. 114.

${ }^{297}$ FISHER, Roger; URY, William; PATTON, Bruce. Como chegar ao sim: a negociação de acordos sem concessões. $2^{\mathrm{a}}$ Ed. Rio de Janeiro: Imago Editora, 2005.

${ }^{298}$ Em 1990, o tema central da conferência da Society of Professionals in Dispute Resolution era "Designing Dispute Resolution Systems".

${ }^{299}$ Não se descarta a existência de outros métodos que também tenham o escopo de criar sistema de solução de conflitos baseados em outras técnicas e princípios que não os preconizados pelo método do DSD. O processo legislativo de normas processuais. 
genericamente, todos buscam evitar perdas e maximizar ganhos. ${ }^{300} \mathrm{O}$ DSD organiza tal pensamento, a partir de princípios e técnicas, na busca da melhor forma de solucionar determinado conflito.

Os princípios e técnicas norteadores do método do DSD na personalização dos sistemas serão mais bem estudados nos próximos tópicos. Contudo, resumidamente é possível apontar pontos de primários de derivação destes princípios e regras. Entre eles, destacam-se a adequação, os custos ${ }^{301}$ e os interesses.

Por mais que seja essencial o conhecimento das peculiaridades do conflito para que se desenvolva o desenho do sistema personalizado, não é indispensável que ele exista no plano fático. Assim, pode-se criar o sistema com base nas características singulares de um determinado tipo de conflito abstrato, por exemplo, indenização por acidente aéreo. $\mathrm{O}$ levantamento das qualidades do objeto dá-se tanto por meio da experiência humana, como pela reflexão. Permite-se que, dessa forma, sejam concebidos sistemas para conflitos completamente novos, nunca antes vivenciados. ${ }^{302}$

Assim, é possível que se desenhe o sistema antes que o conflito surja, até mesmo antes que a relação jurídica de direito material da qual o conflito será proveniente exista. Obviamente, caso se vise preservar os princípios apresentados pelo DSD, eventuais adequações ao caso concreto talvez sejam inevitáveis. Como ainda será analisado, ${ }^{303}$ adequação e readequação são uma constante nos sistemas fundados no DSD.

Uma característica desse método é sua natureza participativa. O sistema, fundado nesses princípios e técnicas, é elaborado por um designer, ${ }^{304}$ juntamente com os interessados. Essa parceria é fundamental para a saúde do sistema, como será mais bem

\footnotetext{
300 "man is a rational maximizer of his ends in life, his satisfactions - what we shall call his 'self-interest' [...] economists generally prefer to speak of 'utility' ". POSNER, Richard Allen. Economic analysis of law. 8 ad. New York: Aspen Publishers, 2011, p. 3.

${ }^{301}$ O termo "custos" é utilizado em uma acepção mais ampla que a financeira, conforme desenvolvido em CUSTOS DO TRATAMENTO DO CONFLITO (COSTS OF DISPUTING), p. 114.

302 Conforme URY, William L.; BRETT, Jeanne M.; GOLDBERG, Stephen B. Getting disputes resolved: designing systems to cut the cost of conflict. $1^{\text {a }}$ Ed. São Francisco: Jossey-Bass Publishers, 1988, p. 1, 4.

${ }^{303}$ Conforme tópico TÉCNICAS, p. 139.

${ }^{304} \mathrm{O}$ designer será um dos sujeitos que estudados no tópico QUEM SÃO OS ATORES (PLAYERS)?, p. 161.
} 
desenvolvido em trecho oportuno desta análise sobre o DSD. Os sistemas devem ser desenhados não para os interessados, mas sim com os interessados. ${ }^{305} 306$

Estes indivíduos contribuirão para a construção do sistema com os recursos que possuem. O designer oferecerá seus recursos técnicos, enquanto os sujeitos do conflito colaborarão com informações sobre o conflito, seus interesses e o contexto em que o fenômeno ocorre, por exemplo.

Eles atuam como um alfaiate que desenvolve um produto sob medida, ${ }^{307}$ único.

Inicialmente, é necessário aferir essas medidas, levantando e analisando as peculiaridades dos personagens, da relação e do objeto conflituoso.

Após essa aquisição de informações, por meios dos princípios e técnicas do DSD, desenham-se elementos que atendam adequadamente a essas características. Estes elementos devem ser compostos de forma a construir um sistema de solução de conflito adequado, ou seja, de baixo custo, possibilitando às partes interessadas e afetadas alcançar seus objetivos, com a maior participação possível e com a satisfação de seus interesses. ${ }^{308}$ 309

Assim, o ideário apresentado pelo DSD colabora com a ideia de que não há uma via principal e única capaz de solucionar adequadamente todo e qualquer conflito. A mesma generalidade, que proporcionaria a esse meio "principal" 310 e único a aptidão de

\footnotetext{
${ }^{305}$ Conforme URY, William L.; BRETT, Jeanne M.; GOLDBERG, Stephen B. Getting disputes resolved: designing systems to cut the cost of conflict. $1^{\text {a }}$ Ed. São Francisco: Jossey-Bass Publishers, 1988, p. xvi.

${ }^{306} \mathrm{Um}$ mecanismo criado de forma impositiva ou com pouca participação dos interessados, tende ao fracasso, não ter legitimidade. COSTANTINO, Cathy A.; MERCHANT, Christina Sickles. Designing conflict management systems. $1^{a}$ Ed. São Francisco: Jossey-Bass, 1996, p. X.

307 "One of the theoretical assets of such a facility is the ability to tailor it to the unique needs of each case". MCGOVERN, Francis E. The what and why of claims resolution facilities. Standford Law Review, Vol. 57, April 2005, p. 1362.

${ }^{308}$ Conforme FALECK, Diego. Introdução ao Design de Sistemas de Disputas: Câmara de Indenização 3054. In Revista brasileira de arbitragem, Ano V, n. 23 São Paulo: IOB, 2009, p. 8.

${ }^{309}$ Conforme URY, William L.; BRETT, Jeanne M.; GOLDBERG, Stephen B. Getting disputes resolved: designing systems to cut the cost of conflict. $1^{\mathrm{a}}$ Ed. São Francisco: Jossey-Bass Publishers, 1988, p. xii.

${ }^{310}$ Cabe esclarecer que não se trata de uma crítica direta ao processo judicial adjudicatório, mas qualquer via de solução de conflito que se tenha por "principal" para a solução de um determinado conflito, mas que seja, na verdade, inadequada, custosa, insatisfatória. Por inúmeras razões e conjunturas, a guerra foi adotada por muito tempo como meio principal para a solução de conflitos entre tribos, reinos, povo, sem que contudo significasse que ela fosse o caminho mais adequado. Situação semelhante ocorre na solução de conflitos dentro de famílias, empresas, organizações.
} 
abranger uma ampla variedade de questões, é a responsável por reduzir sua adequação no tratamento específico dos conflitos. Isso por que perde a capacidade de oferecer as respostas adequadas às necessidades peculiares de cada conflito.

Por não ter um produto pré-definido, o DSD permite a flexibilidade do desenho. Esta maleabilidade, por sua vez, possibilita uma vasta gama de combinações, tão vasta quanto à diversidade de conflitos que existam ou possam vir a existir. O método proporciona sistemas híbridos de mecanismos típicos, podendo, até mesmo, combinar estruturas de vias consensuais e adjudicatórias.

Assim, permite-se que o sistema atue em diferentes frentes, multidisciplinarmente, visando o procedimento e a solução mais adequada. ${ }^{311}$

A multiplicidade de vetores de tratamento tende a se mostrar adequada na solução de conflitos, especialmente os de natureza complexa. Estes podem ser compostos, por exemplo, diversas questões emergentes, aparentemente pontuais, decorrentes de uma relação patologicamente conflituosa. Neste caso, o tratamento sintomático da conjuntura, por meio da composição desses pequenos conflitos emergentes não será suficiente. A solução adequada só será alcançada com o tratamento concomitante das questões emergentes, como também, da relação entre as partes, reorientando-a, de forma a evitar a reincidência de conflitos. ${ }^{312}$

Paralelamente, deve-se aproveitar para extrair benefícios do conflito e de seu tratamento.

\footnotetext{
311 "Today's 'hybrid' processes combine the structures of negotiation, mediation, and arbitration to attempt to perform a wide variety of functions, from relationship reorientation to dispute settlement to conflict resolution to administrative rulemaking and public policy decisionmaking. It would be fascinating to see what Lon Fuller would make of these more flexible procedural institutions as the modern world of social ordering develops increasing complexity and reorganizes structures to meet the requirements of different functions". MEADOW, Carrie Menkel. Mothers and Fathers of Invention: The Intellectual Founders of $A D R$. Ohio: Ohio State Journal on Dispute Resolution, 2000, p. 18.

312 A reincidência de conflitos é elemento relevante na análise dos custos de um sistema, o que atinge diretamente a adequação, como é analisado em CUSTOS DO TRATAMENTO DO CONFLITO (COSTS OF DISPUTING), p. 114.
} 
Os conflitos, por si só, já são inevitáveis, ${ }^{313}$ mas, tornam-se ainda mais frequentes quando indivíduos com interesses incongruentes relacionam-se com regularidade. Periodicamente, estes interesses díspares tornar-se-ão conflitos, gerando disputas.

Essas disputas, contudo, podem ter consequências produtivas, se as partes ventilarem seus interesses conflitantes; realizarem um balanço das perspectivas, posições; alcançarem uma composição que satisfaça as necessidades essenciais de cada um; e prossigam na relação visando à cooperação. Esse processo pode ajudar no crescimento e mudança de pessoas, organizações e relações. ${ }^{314}$

Todavia, apenas a simples utilização de mecanismos adequados, sem nenhuma outra medida, pode não ser suficiente. Os litigantes devem ter motivação, habilidades e recursos para o uso deste novo procedimento. O desenvolvimento desses elementos é tanto um trabalho externo, com o auxílio do designer ou do próprio sistema, como interno aos sujeitos do conflito. ${ }^{315}$

Essas são mudanças que extrapolam o mero oferecimento de uma nova forma de solucionar os conflitos, ainda que esta seja a mais adequada. Educação, treinamento ${ }^{316}$ e, em alguma medida, mudança cultural podem ser indispensáveis para o salutar

\footnotetext{
${ }^{313}$ Conforme FOLLETT, Mary Parker. Prophet of management: a celebration of writings from the 1920s. Beard Books, 1996, p. 67.

${ }^{314}$ Conforme URY, William L.; BRETT, Jeanne M.; GOLDBERG, Stephen B. Getting disputes resolved: designing systems to cut the cost of conflict. $1^{\mathrm{a}}$ Ed. São Francisco: Jossey-Bass Publishers, 1988, p. xii.

${ }_{315}$ Esse desenvolvimento dá-se por meio de técnicas, que são analisadas em tópico próprio. RECURSOS: MOTIVAÇÃO, HABILIDADES, p. 153.

316 "Although the terms training and education are often used interchangeably in the literature and in practice, they are not the same. ADR education provides the contextual background and framework to understand and appreciate the strengths and limitations of ADR: how it furthers institutional and individual goals and where, when, and how to use it. ADR education is a dynamic, ongoing process of increasing awareness about conflict itself, about the typical individual and institucional responses to it, and about potential choices in conflict management. Theses educational approaches generally take the form of ADR marketing and awareness programs for executives, managers, resource allocators, and end users. ADR education occurs formally at conference, meeting, and luncheon presentations as well as informally at the coffee machine and water cooler. In contrast, ADR training is more skill based: building competencies to use $A D R$, improving communication skills, learning mediation practices, and developing negotiation techniques. Training usually involves providing basic dispute resolution skill for users, including communication skills, and advanced technical ADR process skills for potential advocates and neutrals. ADR training is usually competency based and of longer duration than ADR education, as it often involves modifications $f$ attitudes, practices, and behaviors". COSTANTINO, Cathy A.; MERCHANT, Christina Sickles. Designing conflict management systems. $1^{\mathrm{a}}$ Ed. São Francisco: Jossey-Bass, 1996, p. 134.
} 
funcionamento do sistema. ${ }^{317}$ Para que ocorram essas alterações, é salutar que o desenho se dê com os interessados e não apenas para os interessados. ${ }^{318}$

\subsection{PRINCÍPIOS}

\subsubsection{PRINCÍPIO DA ADEQUAÇÃO}

Considerando a premissa de que ADRs são meios adequados de solução de conflitos e que o DSD é, essencialmente, um método de criação sob medida de um sistema de solução de conflito, é possível apontar como princípio basilar do DSD o da adequação. Este seria a pedra de toque da qual decorreriam outros princípios, como o da efetividade, ${ }^{319}$ o da eficiência e o da satisfação.

O princípio da adequação estabelece que deve haver correspondência tanto do método, como de seu produto com os elementos do conflito: sujeitos, objetos, finalidades, como ainda será analisado neste tópico.

Essa correspondência, à luz da racionalidade do DSD, é verificada por meio de uma análise de custos. Este exame não se limita aos custos financeiros, mas também aos custos referentes à satisfação das partes com o resultado, aos efeitos do procedimento e seus produtos para os sujeitos e sua relação, aos custos de transação, entre outros que ainda serão estudados.

Dessa forma, conclui-se que, para o DSD, é adequado um sistema que apresenta baixo custo.

\footnotetext{
${ }^{317}$ A mudança de cultura que pode se mostrar necessária para a adequada solução do conflito, conforme os estudos sobre a cultura da pacificação elaborados por Kazuo Watanabe. WATANABE, Kazuo. Cultura da sentença e cultura da pacificação. In YARSHELL, Flávio Luiz; MORAES, Maurício Zanoide de (Org.). Estudos em homenagem à professora Ada Pellegrini Grinover. $1^{\text {a }}$ Ed. São Paulo: DPJ Editora, 2005, p. 685.

${ }_{318}$ COSTANTINO, Cathy A.; MERCHANT, Christina Sickles. Designing conflict management systems. $1^{\mathrm{a}}$ Ed. São Francisco: Jossey-Bass, 1996, p. 20.

${ }^{319}$ Luiz Guilerma Marinoni, no entanto, em seus estudos do processo adjudicatório estatal, afirma a relação oposta. Segundo ele a adequação seria meio para se alcançar a efetividade. (MARIONI, Luiz Guilherme. Novas linhas do processo civil. $3^{\text {a }}$ Ed. São Paulo: Malheiros, 1999, p. 204).
} 
Quanto aos mecanismos, o princípio da adequação decorre da própria natureza instrumental do processo. Como instrumento, deve ser adequado ao seu fim, sob pena de ser inútil ao que se propõe.

Esse raciocínio pode ser estendido para alguns métodos ${ }^{320}$ de criação de instrumentos, como o DSD.

O DSD não é o único método de criação de sistemas e seria temerário indicar a adequação como viga mestra de todo e qualquer método de criação.

O processo legislativo, por exemplo, também é um processo criador de sistemas de solução de conflito. Contudo, frente aos fundamentos e objetivos da República Federativa do Brasil previstos na Constituição, ${ }^{321}$ seria um equivoco crasso afirmar que este método tem como cerne a adequação.

Cabe lembrar que o DSD e seus produtos têm uma racionalidade própria e, assim, seus principais vetores, muitas vezes, apesar de semelhantes, não coincidam com os dos mecanismos típicos, como os da adjudicação estatal. ${ }^{322}$

Ao decompor o princípio da adequação, é possível isolar critérios norteadores das modelagens e também observar diferentes momentos de atuação.

Quanto aos pontos de convergência da adequação ou critérios que guiam a aplicação do princípio, o sistema deve ser adequado i) quanto aos sujeitos, ii) quanto ao objeto do conflito e iii) quanto à sua finalidade. Estes são os planos subjetivo, objetivo e

\footnotetext{
${ }^{320}$ Utiliza-se o termo "método" no plural, pois não se pode negar a existência de outros procedimentos técnicos de criação de mecanismos de solução de conflitos que sejam norteados por regras e princípios diversos dos trazidos pelo ideário do DSD. Como ocorre, por exemplo, com o próprio processo legislativo para a criação de normas processuais.

${ }^{321}$ Conforme artigo $1^{\circ}$ e $3^{\circ}$ : Art. $1^{\circ}$ A República Federativa do Brasil, formada pela união indissolúvel dos Estados e Municípios e do Distrito Federal, constitui-se em Estado Democrático de Direito e tem como fundamentos: I - a soberania; II - a cidadania; III - a dignidade da pessoa humana; IV - os valores sociais do trabalho e da livre iniciativa; V - o pluralismo político. Art. $3^{\circ}$ Constituem objetivos fundamentais da República Federativa do Brasil: I - construir uma sociedade livre, justa e solidária; II - garantir o desenvolvimento nacional; III - erradicar a pobreza e a marginalização e reduzir as desigualdades sociais e regionais; IV - promover o bem de todos, sem preconceitos de origem, raça, sexo, cor, idade e quaisquer outras formas de discriminação.

${ }^{322}$ Considerando as garantias individuais, as garantias processuais, regras e princípios norteadores do Estado brasileiro previstos na Constituição Federal de 1988 e as demais normas processuais infraconstitucionais, fica claro que o legislador, quando da produção normativa processual, e o magistrado, no exercício de sua função jurisdicional, têm o dever de observância de previsões legais que não se estendem, em regra, ao DSD.
} 
teleológico do princípio da adequação, ${ }^{323}$ que apresentam entre si relação de complementariedade.

O plano subjetivo consiste na modulação do sistema em razão das peculiaridades das partes, de forma a atender apropriadamente aos interesses e às características desses sujeitos.

Pode-se utilizar como exemplo a Câmara de Indenização 3054 (CI3054). ${ }^{324}$ Para atender aos potenciais beneficiários que se concentravam na região das cidades de São Paulo-SP e Porto Alegre-RS, previu-se postos de atendimento nas duas cidades, como também o transporte dessas pessoas. Com isso, buscava-se evitar que a dificuldade de acesso tornasse o sistema inadequado, inviabilizando-o ou desestimulando a adesão a ele.

O princípio da adequação também é aplicado, sob a perspectiva subjetiva, em relações jurídicas de direito material em que há "disparidade de armas" entre as partes, como é o caso de relações de consumo.

A disparidade de $\operatorname{armas}^{325}$ é sempre uma constante na solução de conflitos, frente à diversidade dos sujeitos e das relações. Assim, um sistema que prese pela adequação deve prever algum artifício para amenizar essas discrepâncias. Por exemplo, com a participação das autoridades públicas responsáveis pela defesa dos interesses dos consumidores, como ocorreu nos dois casos a ser estudados.

Por sua vez, o plano objetivo do princípio da adequação está relacionado com o conflito e suas características.

Os conflitos podem ser enquadrados em tipos abstratos. Estes gêneros, por sua vez, comportam espécies, e estas, os conflitos reais, latentes, interpessoais, por exemplo. Essas classes e subclasses são estabelecidas por meio de critérios baseados nas

\footnotetext{
323 Conforme entendimento de LACERDA, Galeano. O código como sistema legal de adequação do processo. In: Revista do instituto dos advogados do Rio Grande do Sul. Porto Alegre, 1976, p. 166.

${ }^{324}$ VOO TAM 3054 E VOO AIR FRANCE 447, p. 177.

${ }^{325}$ Analisa-se o tema em CARACTERÍSTICAS DOS MECANISMOS CONSENSUAIS, p. 69.
} 
características e peculiaridades dos conflitos. $^{326}$ Esses elementos trazem consigo necessidades, às quais o sistema deve proporcionar a resposta adequada.

Dessa forma, um sistema que se pretende adequado, por exemplo, à indenização de agricultores que tiveram suas terras contaminadas por uma indústria, deve ter alguma expertise quanto à dinâmica agrária e, paralelamente, conter procedimentos eficientes e efetivos para analisar a dimensão e a intensidade dessa contaminação.

Pode-se pensar também, como ilustração, na indenização de caráter alimentar devido ao falecimento do arrimo de família. Nestes casos, uma possibilidade seria agilizar a averiguação de legitimidade do beneficiário à indenização e antecipar uma determinada quantia para a sua subsistência ao longo do procedimento.

Por fim, a adequação teleológica observa os escopos imediatos do mecanismo.

Por mais que o escopo fim processo seja a pacificação social, ele também apresenta fins próximos, como definir o direito, efetivar o direito declarado, acautelar um futuro processo ou facilitar a comunicação dos sujeitos do conflito para que consigam se compor adequadamente. Os mecanismos, para que preservem a sua adequação teleológica devem ter instrumentos correspondentes aos seus fins.

Aproveitando a ilustração quanto às terras contaminadas, deve se ter em mente que um sistema que tenha como objetivo repara a contaminação das propriedades por meio da descontaminação destas, será diferente de um que tenha como fim apenas indenizar financeiramente os proprietários.

Além dos pontos de concentração, o princípio da adequação pode ser analisado quanto aos seus momentos. Este princípio está presente i) na fase inicial do DSD, na qual é feito o levantamento das características peculiares do caso e o desenho do sistema, ii)

326 “[o princípio da adaptabilidade] orienta os procedimentos no sentido da útil aderência às peculiaridades e exigências da situação jurídico-substancial". DINAMARCO, Cândido Rangel. Das ações típicas. In Fundamentos do processo civil moderno. Tomo I, $3^{\text {a }}$ Ed. São Paulo: Malheiros, 2000, p. 342. 
posteriormente, durante a utilização do instrumento criado para a solução do conflito posto e, iii) por fim, após o término do procedimento, quando há a avaliação do sistema. ${ }^{327}$

Esta primeira etapa é definida pela atividade criadora de estruturas adequadas aos sujeitos, ao objeto e à finalidade. Há a análise por parte do designer, junto com as partes, das peculiaridades existentes no caso e a criação do sistema de solução de conflito. Essa atividade assemelha-se ao processo legislativo de criação de normas processuais. Assim como o designer, o legislador deve criar artifícios capazes de tornar o mecanismo adequado. $^{328}$

Ressalta-se, todavia, que, por mais que semelhantes quanto à criação adequada de mecanismos, essas duas atividades distinguem-se em relação às normas que as direcionam, como já mencionado quando da introdução do princípio.

No segundo momento, são realizadas adaptações ao longo da aplicação do sistema.

Os sujeitos, suas relações e seus conflitos não são estáticos, mas sim dinâmicos. Dessa forma, para que o sistema se mantenha adequado em relação a esses elementos, deverá acompanhar a oscilação deles. Ou seja, a adequação não pode ser aferida tendo como base uma única imagem estática da conjuntura, sob pena do sistema manter correspondência com a imagem estática e não com a realidade.

Como solução, são necessárias constantes aferições e readequações.

\footnotetext{
${ }^{327}$ Segundo Fredie Didier, o princípio da adequação, quando aplicado ao mecanismo de solução de conflito adjudicatório estatal, apresenta dois momentos de concentração. No primeiro, o princípio está direcionado ao o legislador e a sua função de criador de normas processuais. Dessa forma, a adequação nortearia o processo normativo. O segundo momento é denominado de jurisdicional, ou ainda, "princípio da adaptabilidade", "princípio da elasticidade" ou "princípio adequação formal do processo", e permite ao juiz adequar o procedimento às peculiaridades do caso concreto que lhe é submetido. (DIDIER JR., Fredie. Curso de direito processual civil. Vol. I. 15ª Ed. Salvador: Editora Juspodivm, 2013, p. 84).

328 "Inicialmente, a própria construção do procedimento deve ser feita tendo-se em vista a natureza e as peculiaridades do objeto do processo a que servirá; o legislador deve atentar para estas circunstâncias, pois um procedimento inadequado ao direito material pode importar verdadeira negação da tutela jurisdicional. $\mathrm{O}$ princípio da adequação não se refere apenas ao procedimento. A tutela jurisdicional há de ser adequada; o procedimento é apenas uma forma de encarar este fenômeno". Conforme DIDIER JR., Fredie. Curso de direito processual civil. Vol. I. 15ª Ed. Salvador: Editora Juspodivm, 2013, p. 84.
} 
Essa técnica também permite que eventuais falhas sejam corrigidas, estabelecendo ou restabelecendo a adequação.

Mesmo que excepcionalmente, existem algumas hipóteses que permitem ao juiz readequar o procedimento para, por exemplo, resguardar a ampla defesa no caso concreto, por meio da dilação de um prazo ou permissão de uma nova manifestação.

Em vias consensuais, as partes poderiam acordar quanto à alteração ou flexibilização do procedimento, almejando propiciar uma solução satisfatória.

Paralelamente, é possível levantar a hipótese de que, dependendo do sistema criado, seja consensual, adjudicatório ou misto, a necessidade de adequação ao longo do procedimento seria suprida normalmente pela brandura e brevidade das formas. ${ }^{329}$ Não se afasta a existência de formas, mas estas estão sempre buscando a adequação do sistema e, assim, a solução adequada. Qualquer forma inútil ou que desvirtue o sistema desse fim seria, na verdade, uma deformação. Desse modo, ela deve ser harmonizada nesta segunda fase ou, posteriormente, na fase de feedback e readequação.

Eventuais alterações, contudo, devem ter fundamento na adequação. Mudanças aleatórias tornariam o sistema inseguro, mais custoso, logo, inadequado.

Por fim, o terceiro momento. Ele ocorre após o processo, tendo ou não chegado a uma solução. Levantam-se informações e avalia-se o sistema. Essa técnica do feedback ${ }^{330}$ é típica do DSD.

As readequações provenientes deste balanço de resultados podem vir a beneficiar futuras demandas tratadas pelo sistema ou, até mesmo, no desenho de futuros sistemas.

Os sistemas criados para tratar as tragédias aéreas da TAM e Air France ${ }^{331}$ sucederam-se no tempo. Assim, os erros e acertos do primeiro mecanismo tornaram-se recursos informativos para o desenho do segundo.

329 "ADR is not so much informalism as 'short form formalism". GALANTER, Marc. Compared to what? Assessing the quality of dispute processing. In: Denver University Law Review, n. 66, 1988-1989, p. XIV.

${ }^{330}$ Conforme tópico FEEDBACK, p. 152. 
Após a análise deste princípio, fica mais claro o seu papel, previsto pelo método do DSD e aplicado aos produtos provenientes dele. Do princípio da adequação decorrem outros princípios que também norteiam a criação de um sistema que seja de baixo custo.

\subsubsection{PRINCÍPIO DA EFETIVIDADE}

Considerando a pretensão apresentada, o conflito, as normas e/ou os interesses das partes, ${ }^{332}$ o que seria uma solução efetiva?

Tendo em vista as formas básicas de tratamento de conflito, ou seja, poder, regras e interesse, ${ }^{333}$ as soluções efetivas dão-se de forma diferente.

A efetividade do procedimento baseado em regras deverá ser avaliada à luz do direito material, assim como ocorre com a adjudicação estatal, ${ }^{334} 335$ ou à luz do conjunto normativo aplicado ao sistema. Dessa forma, será efetivo o mecanismo que definir corretamente qual é a demanda que procede, isto é, está conforme ordenamento normativo aplicado.

Por sua vez, mecanismos baseados em interesse serão efetivos ao entregarem soluções compatíveis com as necessidades, pretensões, desejos, sentimentos dos sujeitos do conflito.

A avaliação de efetividade nos dois casos apresentam critérios diferentes: i) solucionar conforme a norma, ii) solucionar conforme o interesse.

\footnotetext{
${ }^{331}$ VOO TAM 3054 E VOO AIR FRANCE 447, p. 177.

${ }^{332}$ Tendo em vista as formas básicas de solucionar um conflito, ou seja, força, direito e interesse, a

${ }^{333}$ INTERESSE, REGRA E PODER: BASES DA SOLUÇÃO DE CONFLITOS, p. 37.

334 "Processo efetivo é aquele que tem, observado o equilíbrio em que os valores segurança e celeridade, proporciona às partes o resultado desejado pelo direito material". BEDAQUE, José Roberto dos Santos. Efetividade do processo e técnica processual. $3^{\text {a }}$ Ed. São Paulo: Malheiros Editores, 2010, p. 49.

${ }^{335}$ DIDIER JR., Fredie. Curso de direito processual civil. Vol. I. 15 ${ }^{\text {a }}$ Ed. Salvador: Editora Juspodivm, 2013, p. 83.
} 
A realidade, contudo, traz alguns desafios. As disposições do conjunto normativo utilizado nos sistemas baseados em regras podem não coincidir com os interesses dos sujeitos do conflito.

Mesmo que conforme o direito material, uma sentença condenatória não satisfará aos interesses do sucumbente. Ainda que se analise na perspectiva do vencedor, não é certa a congruência entre o determinado nesta decisão judicial e seus interesses.

Em uma análise objetiva, poder-se-ia afirmar ser essa uma solução efetiva, por tutelar o direito subjetivo violado e garantir o previsto pelo direito material. Mas, em uma análise subjetiva da efetividade no caso concreto, a parte não estaria satisfeita e a pacificação social não teria sido realmente alcançada.

Observa-se, com isso, mais um critério de avaliação da efetividade: a concreta pacificação social.

Considerando este critério, na hipótese do direito subjetivo ser diverso do interesse da parte, é questionável a efetividade de um mecanismo baseado em regras, já que se tende a não alcançar a concreta pacificação social.

Estes critérios devem ser ponderados quando do desenho do sistema, inclusive quanto a qual racionalidade base adotar. Deve haver a mesma atividade durante a aplicação do sistema ao tratamento do conflito.

A efetividade, assim como a eficiência, como ainda será analisado, é comumente ligada à economia processual e à celeridade. ${ }^{336} \mathrm{~A}$ demora na solução do conflito e na tutela do direito e/ou interesse resultam, necessariamente, na falta de

\footnotetext{
${ }^{336}$ A defesa da celeridade deve ser feita de modo a encontrar equilíbrio com outras garantias do devido processo legal, conforme entendimento de José Roberto dos Santos Bedaque: "Mas constitui perigosa ilusão pensar que simplesmente conferir-lhe celeridade é suficiente para alcançar a tão almejada efetividade. Não se nega a necessidade de reduzir a demora, mais não se pode fazê-lo em detrimento do mínimo de segurança, valor também essencial ao processo justo. Em princípio, não há efetividade sem contraditório e ampla defesa. A celeridade é apenas mais uma das garantias que compõe a ideia de devido processo legal, não a única". BEDAQUE, José Roberto dos Santos. Efetividade do processo e técnica processual. $3^{\mathrm{a}}$ Ed. São Paulo: Malheiros Editores, 2010, p. 49.
} 
efetividade, em injustiça e insatisfação. A justiça que tarda, não só é injustiça, como lesa o patrimônio, a honra, a liberdade e o interesse das partes. ${ }^{337}$

A plena procedência de uma demanda quando o decorrer do tempo fez com que a indenização fosse a única opção remanescente, não tutela efetivamente o direito material, nem o interesse das partes.

Dessa forma, o princípio da efetividade, quando aplicado ao DSD, indica que deve haver a pronta, integral e específica satisfação do direito e/ou do interesse. ${ }^{338}$

\subsubsection{PRINCÍPIO DA EFICIÊNCIA}

O princípio da eficiência, por sua vez, está ligado ao princípio da boa gestão do processo, ${ }^{339}$ à economia processual, ${ }^{340}$ à ideia de produtividade, ao custo-benefício, à busca da combinação ideal entre meios e fins para maximizar benefícios e minorar custos. Dessa forma, está diretamente relacionado aos custos e aproxima-se das ciências da administração e da economia. ${ }^{341}$

Todavia, a simples análise da eficiência não garante um processo adequado.

\footnotetext{
337 "Mas justiça atrasada não é justiça, senão injustiça qualificada e manifesta. Porque a dilação ilegal na mão do julgador contraria o direito escrito das partes, e, assim, as lesa no patrimônio, honra e liberdade. Os juízes tardinheiros são culpados, que a lassidão comum vai tolerando. Mas sua culpa tresdobra com a terrível agravante de que o lesado não tem meio de reagir contra o delinquente poderoso, em cujas mãos jaz a sorte do litígio pendente." BARBOSA, Rui. Oração aos moços. São Paulo: Editora Martin Claret, 2004, p. 53.

${ }^{338}$ Ao conceito dado por Marcelo Lima Guerra foi acrescido o elemento interesse", para assim tornar adequada à racionalidade do DSD, especialmente, dos mecanismos de solução de conflito baseados em interesse. GUERRA, Marcelo Lima. Direitos fundamentais e a proteção do credor na execução civil. São Paulo: Editora Revista dos Tribunais, 2003, p. 102.

${ }^{339}$ Conforme DIDIER JR., Fredie. Curso de direito processual civil. Vol. I. 15 ${ }^{\mathrm{a}}$ Ed. Salvador: Editora Juspodivm, 2013, p. 72.

340 "A aplicação do princípio da eficiência ao processo é uma versão contemporânea (e também atualizada) do conhecido princípio da economia processual. Muda-se a denominação, não apenas por que é assim que ela aparece no texto constitucional, mas, sobretudo, por ser uma técnica retórica de reforço da relação entre este princípio e à atuação do juiz como um administrador - ainda que a administrador de um determinado processo". DIDIER JR., Fredie. Curso de direito processual civil. Vol. I. 15 ${ }^{\text {a }}$ Ed. Salvador: Editora Juspodivm, 2013, p. 72.

341 "The many reasons for preferring one dispute mechanism over another can be reduced to two basic arguments. The first of these, which we might call the 'production' cluster, is that one or another mechanism will produce 'more' with less expenditure of resources. Thus we find arguments that a given device will increase the number and speed of resolutions and lower their cost. A great deal of talk about alternatives consists of claims about production effects". GALANTER, Marc. Compared to what? Assessing the quality of dispute processing. In: Denver University Law Review, n. 66, 1988-1989, p. XII.
} 
A eficiência é calculada por meio da relação dos recursos empregados e dos resultados obtidos. Ou seja, examina-se uma relação e não qualidades.

Um carro popular é mais eficiente energeticamente que uma Ferrari, mas o resultado de desempenho dela é muito superior.

Um procedimento no qual se solucione uma disputa com base na sorte, caraou-coroa, por exemplo, pode ser tido como eficiente, considerando o baixo custo de procedimento e a solução alcançada.

Com isso, estabelece-se a ressalva que a eficiência é um princípio norteador do DSD e seus sistemas, mas que não deve ser considerada isoladamente.

Além da ligação entre a eficiência e a adequação, outra marca do princípio da eficiência no DSD é a aptidão deste método na solução de causas repetidas ou semelhantes, isto é, que pertençam ao mesmo tipo de conflito para o qual o sistema foi arquitetado.

Seja compondo conflitos entre membros de uma organização, seja indenizando grandes tragédias, os sistemas baseados no DSD podem acolher múltiplos casos, desde que pertencentes ao tipo de conflito para o qual foi desenhado.

Com isso, diluem-se os custos da criação de um sistema específico, o que influencia positivamente a adequação do sistema.

Considerando as técnicas aplicadas ao procedimento, é possível, a priori e abstratamente, qualificá-lo como eficiente ou não. ${ }^{342}$ Cabe ainda análise a posteriori para confirmar essa qualidade. Entende-se que o mesmo raciocínio é compatível com a efetividade. Dessa forma, esses diferentes momentos de averiguação da eficiência e da efetividade norteariam o designer e as partes quanto à adequação do sistema.

A efetividade e a eficiência, apesar de próximas, apresentam pontos de concentração distintos.

\footnotetext{
${ }^{342}$ Em sentido contrário, Fredie Didier Jr. Entende: "um procedimento eficiente é inconcebível a priori: a eficiência resulta de um juízo a posteriori [...] sempre retrospectivo". DIDIER JR., Fredie. Curso de direito processual civil. Vol. I. 15 Ed. Salvador: Editora Juspodivm, 2013, p. 73.
} 
Para se avaliar um sistema quanto a sua efetividade, deve-se centrar atenção predominantemente nos resultados.

A eficiência, como desenvolvido, é resultado da análise da relação entre recursos aplicados e os produtos alcançados e sua aferição concentra-se no procedimento e não no resultado. Os pontos de concentração de um e de outro princípio é uma das principais formas de distingui-los. ${ }^{343}$

\subsubsection{PRINCÍPIO DA SATISFAÇÃO}

Outro princípio norteador do DSD é o da satisfação. Este princípio é composto de fatores subjetivos que remetem à percepção das partes sobre a justiça do procedimento e da solução alcançada.

Devido a essa essência subjetiva, tem-se o desafio de não só ofertar um sistema adequado para a solução de um determinado conflito, mas também de criar essa sensação nas partes. Isto é, não basta ser, é preciso que as qualidades atinjam a percepção dos sujeitos do conflito.

Dessa forma, um procedimento desequilibrado, obscuro, e uma solução arbitrária ou imposta fora da concordância da parte, tende a não satisfazê-la.

As partes podem ter alcançado a melhor solução possível para o seu conflito, contudo, caso elas não tenha informações sobre as outras possibilidades, elas podem acreditar que conseguiriam algo ainda melhor, ficando insatisfeitas com a presente solução.

\footnotetext{
${ }^{343}$ Essa forma de distinção, todavia, não é a única. Fredie Didider Júnior entende que "Efetivo é o processo que realiza o direito afirmado e reconhecido judicialmente. Eficiente é o processo que atingiu esse resultado de modo satisfatório, nos termos acima". Contudo, na sua análise da efetividade e da eficiência aplicada à adjudicação estatal, o autor estabelece a necessária presença da eficiência em um processo efetivo. "Um processo pode ser efetivo sem ter sido eficiente - atingiu-se o fim "realização do direito" de modo insatisfatório (com muitos resultados negativos colaterais e/ou excessiva demora, por exemplo). Mas jamais poderá ser considerado eficiente sem ter sido efetivo: a não realização de um direito reconhecido judicialmente é quanto basta para a demonstração da ineficiência do processo". Este entendimento é diverso do apresentado neste estudo: DIDIER JR., Fredie. Curso de direito processual civil. Vol. I. 15 ${ }^{\text {a }}$ Ed. Salvador: Editora Juspodivm, 2013, p. 74.
} 
Trata-se de uma questão de falta de recursos informativos. É necessário que as partes sejam informadas sobre as suas possibilidades, tenham parâmetros de comparação, ${ }^{344}$ para poderem criar uma percepção realista quanto às possibilidades e ao sistema que lhes é proposto.

Adicionalmente, deve ser lembrado também que os sistemas baseados no DSD apresentam qualidades inerentes que, pelo menos no plano ideal, o fazem ser o melhor caminho para a solução de um determinado conflito, por sua própria natureza, sem que seja necessária a comparação, afinal, o sistema foi criado "sob medida". Ademais, deve-se voltar à perspectiva dos $\mathrm{ADRs}$ como meios adequados. Ou seja, um mecanismo não é bom ou ruim em abstrato, mas sim, adequado ou inadequado para este ou aquele tipo de conflito.

Dessa forma, a satisfação das partes está diretamente relacionada às informações que elas têm para construir sua percepção sobre o sistema.

Fechando o presente tópico, cabe antecipar a informação que a satisfação não é apenas um princípio, ou seja, um norte para o desenho e seus sistemas, mas também um componente dos custos de solução de conflitos.

\subsubsection{PRINCÍPIO DO DSD - URY, BRETT, GOLDBERG}

Em uma perspectiva mais pragmática, os idealizadores do DSD, entendem pela existência de 6 princípios: ${ }^{345}$ i) o conflito deve ser tratado, preferencialmente, com foco nos interesses das partes; ii) o sistema de solução de conflito deve ser desenhado de forma escalonada, prevendo diferentes mecanismos em sequência, do menos para ao mais custoso; ${ }^{346}$ iii) apesar da ênfase no interesse, devem ser previstos procedimentos de baixo custo, baseados em regras e força, que funcionem como vias complementares, caso os métodos consensuais baseados em interesse venham a falhar; iv) o procedimento

\footnotetext{
${ }^{344}$ Conforme tópico PARÂMETROS REFERENCIAIS155

${ }^{345}$ Conforme URY, William L.; BRETT, Jeanne M.; GOLDBERG, Stephen B. Getting disputes resolved: designing systems to cut the cost of conflict. $1^{\mathrm{a}}$ Ed. São Francisco: Jossey-Bass Publishers, 1988, p. xv.

${ }^{346}$ Conforme tópico CUSTOS DO TRATAMENTO DO CONFLITO (COSTS OF DISPUTING), p. 114.
} 
desenhado deve ser criado de forma a encorajar os litigantes a voltar à negociação; v) devem ser desenhados mecanismos profiláticos, que previnam o surgimento do conflito ou da disputa, baseados em procedimentos de consulta prévia ou de feedback das partes e interessados em relação às soluções alcançadas pelo sistema; vi) deve-se providenciar motivação, habilidades e os recursos necessários às partes, aos interessados e aos sujeitos necessários para fazer o mecanismo funcionar.

Cabe estabelecer a ressalva de que, por mais que os autores classifiquem estes pontos como princípios, os itens elencados têm natureza de técnica.

Constata-se que as quatro primeiras técnicas remetem às três formas básicas de solução de conflitos: interesse, regra e poder, conforme desenvolvido anteriormente. ${ }^{347}$ Resumidamente, indicam que se deve dar prioridade para sistemas de baixo custo, considerando que cada uma dessas vertentes tem custos próprios e estes têm estreita relação com a adequação dentro de ideário do DSD.

Adicionalmente, para que se tenha um sistema com menor probabilidade de falha e, dessa forma, com menor probabilidade de desperdício, de ineficiência, de inefetividade e de insatisfação, ele deve ser redundante. Isto é, ele deve ser composto por vias paralelas que supram umas às outras buscando evitar que o todo entre em colapso. A sequência de quais caminhos usar, caso seja necessário, é determinada pela respectiva adequação. Isto é, do menos para o mais custoso. Sendo assim, simplificadamente, o escalonamento iniciaria com mecanismos baseados em interesse, sucedidos pelos fundados em regras e, por fim, pelos baseados em força. A cada degrau, aumenta-se o grau certeza quanto ao fim da disputa, contudo, diminui-se o nível de adequação do processamento e da solução.

Juntamente com essas redundâncias, devem ser desenhados atalhos de volta ao caminho inicial e ideal, com seus benefícios. Segundo os autores, ${ }^{348}$ as partes devem ser tanto encorajadas a utilizar esses retornos à negociação baseada em interesse, como devem ter facilitado o acesso a eles.

\footnotetext{
${ }^{347}$ Conforme tópico INTERESSE, REGRA E PODER: BASES DA SOLUÇÃO DE CONFLITOS, p. 37.

${ }^{348}$ Conforme URY, William L.; BRETT, Jeanne M.; GOLDBERG, Stephen B. Getting disputes resolved: designing systems to cut the cost of conflict. $1^{\text {a }}$ Ed. São Francisco: Jossey-Bass Publishers, 1988, p. 52.
} 
Desse modo, a variação negativa da adequação ao longo de escalonamento, bem como a existência de retornos a vias mais adequadas tornam-se dados a serem calculados pelas partes nas suas atividades decisórias. Os sujeitos sabem que o ideal é a fase inicial e que, com o insucesso das etapas, os custos vão se elevando e que, assim, devem preferencialmente compor-se nesta primeira etapa.

Caso o conflito permita, o sistema ainda deve atuar em dois momentos adicionais: antes da eclosão do conflito em uma disputa e após a aplicação do sistema.

Como medida profilática, devem ser previstos procedimentos para conter a evolução do conflito, dirimindo-o ainda em uma fase inicial a baixo custo. Estruturas de aconselhamento normalmente existentes junto aos departamentos jurídico ou pessoal de empresas são um exemplo de medida preventiva na contenção e solução de conflitos.

No outro extremo, após a aplicação do sistema, devem estar presentes estruturas baseadas no feedback. Elas possibilitariam tanto a avaliação e readequação do sistema, como também, supririam eventuais lacunas para soluções de questões futuras. ${ }^{349}$

Criar um mecanismo adequado que auxilie as partes a alcançar uma composição efetiva e satisfatória depara-se com diversos desafios. Como persuadir pessoas que estão acostumadas a brigar, processar, entrar em greve e ameaçar, a passar a resolver seus conflitos de forma amigável? Em relações novas, nas quais ainda não existem estes costumes, nem estas animosidades, mas também não está solidificada a confiança, como garantir condutas efetivas e cooperativas na busca de uma solução adequada? O plano fático pode trazer dificuldades ainda maiores do que as descritas. Apesar do menor custo das vias consensuais baseadas em interesse, os diversos vetores existentes para os sujeitos do conflito, podem fazer com que essa constatação não seja simples e clara. Para tanto, fechando a análise dos seis elementos trazidos por Ury, Brett e Goldberg, é necessária a promoção de motivação, de habilidades e dos recursos necessários às partes, aos interessados e aos sujeitos necessários para fazer o mecanismo funcionar.

\footnotetext{
${ }^{349}$ No caso IBM-Fujitsu, após sanado o conflito quanto ao uso das patentes, foi estipulado, dentro do sistema de personalizado existente, estruturas para gerenciar as novas hipóteses de uso e pagamento pelo uso das patentes de forma rápida e efetiva. URY, William L.; BRETT, Jeanne M.; GOLDBERG, Stephen B. Getting disputes resolved: designing systems to cut the cost of conflict. $1^{\text {a }}$ Ed. São Francisco: Jossey-Bass Publishers, 1988, p. xiii.
} 


\subsection{CUSTOS DO TRATAMENTO DO CONFLITO (COSTS OF DISPUTING)}

A adequação, como desenvolvida dentro do ideário do DSD, está intimamente relacionada com os custos. Os mecanismos, assim como as diferentes formas base, interesse, direito e poder, adotados para a solução dos conflitos, geram custos e ganhos próprios. Estes, contudo, devem ser considerados de forma ampla, extrapolando os limites do campo financeiro.

Os custos são formados por um grande número de vetores de várias naturezas e orientados em diversas direções, somando-se e potencializando-se ou subtraindo-se e abrandando-se. Na busca por tornar o fenômeno dos custos cognoscível, é possível a utilização de diferentes critérios para classificar e racionalizar seus elementos.

Marc Galanter, por exemplo, visando dar ensejo à comparação dos mecanismos de solução de conflito, apresenta dois grupos de critérios para a análise dos custos. ${ }^{350}$

No primeiro, os custos dos mecanismos são apurados segundo a produtividade. Assim, verifica-se a relação entre a produção e o consumo de recursos, como o tempo gasto para produzir um determinado número de resultados. Nesta perspectiva, tem-se uma análise quantitativa e não qualitativa dos produtos e seus sistemas.

As qualidades e os benefícios são os critérios do segundo agrupamento. Deste conjunto desdobram-se a satisfação das partes, o estimulo ao restabelecimento da relação,

\footnotetext{
350 "The first of these, which we might call the "production" cluster, is that one or another mechanism will produce "more" with less expenditure of resources. Thus we find arguments that a given device will increase the number and speed of resolutions and lower their cost. A great deal of talk about alternatives consists of claims about production effects. Due to the infirmities of selection and measurement that often attend reform undertakings, there is probably a tendency to overestimate the degree to which programs achieve such production effects. Even where it can be shown that one process is cheaper and faster than another, such a demonstration is necessarily incomplete, for it is necessary to ask whether what is obtained for the lower cost is equally desirable. We arrive at the question of the benefits or qualities that we attribute to the rival arrangements. This brings us to our second great cluster of arguments-assertions about the superiority of alternative processes or the outcomes that they produce. For example, it may be argued that a given process is superior because it increases the parties' satisfaction, encourages the re-establishment of friendly relations, is more suffused by social norms, fosters integrative solutions, leads to more compliance, generates useful precedents, and so forth". GALANTER, Marc. Compared to what? Assessing the quality of dispute processing. In: Denver University Law Review, n. 66, 1988-1989, p. XII.
} 
estar imbuído por norma social, propiciar soluções integrativas e seu efetivo cumprimento, gerar precedentes úteis, entre outros.

Conforme Ury, Brett e Goldberg, quando do desenho de um sistema de solução de conflitos à luz do DSD, deve-se considerar o custo da disputa, custo de disputar ou custo do tratamento do conflito (cost of disputing). ${ }^{351}$ Ele se decompõe em quatro elementos: i) custos de transação, ii) satisfação com os resultados, iii) consequências para a relação entre as partes e iv) a possibilidade de reincidência do conflito.

Constata-se que, por meio de critérios diversos, mas semelhantes, os autores estudam o mesmo objeto, sem que uma classificação inutilize a outra.

Os quatro elementos trazidos por Ury, Brett e Goldberg ${ }^{352}$ estão interrelacionados. A insatisfação com os resultados obtidos, por exemplo, pode causar danos à relação das partes que, por sua vez, contribuem para que haja reincidência de conflitos e de disputas, que gera aumento dos custos de transação. As relações de causa e consequência entre esses quatro elementos podem ser compostas de múltiplas formas.

No entanto, a análise de custo não se resume a uma dinâmica simples na qual se busca os valores mais baixos para cada elemento. Eventualmente, o aumento do custo de um desses fatores pode resultar em melhorias em outros aspectos, reduzindo o costs of disputing como um todo. Ou seja, o estudo dos custos deve ser feito tanto na esfera de cada elemento, como abordar a interação entre eles, de forma a compor uma visão global sobre o custo.

\footnotetext{
351 "We focus on four criteria in comparing them: transaction costs, satisfaction with outcomes, effect on the relationship, and recurrence of dispute". URY, William L.; BRETT, Jeanne M.; GOLDBERG, Stephen B. Getting disputes resolved: designing systems to cut the cost of conflict. $1^{a}$ Ed. São Francisco: Jossey-Bass Publishers, 1988, p. 11.

${ }^{352}$ Considerando que os critérios de Ury, Brett e Goldberg de análise de custos são apresentados na obra de apresentação do Dispute System Design, optou-se por adota-los.
} 


\subsubsection{CUSTOS DE TRANSAÇÃO}

Os custos de transação são a união de algumas espécies de custos. Desse modo, pode ser decomposto em: i) custos relacionados ao intervalo de tempo despendido para se chegar a uma solução do conflito, aumentando com a demora e diminuindo com a celeridade; ii) custo econômico, que está ligado aos recursos financeiros, seus gastos, alocação, entre outros aspectos de mesma natureza; iii) custo emocional, normalmente, remetem aos sentimentos negativos apresentados e enfrentados pelas partes ao longo do conflito, da disputa e do processo de solução, como stress, tristeza, desconforto, raiva; iv) os recursos consumidos e destruídos, sendo estes diversos dos financeiros, já considerados no segundo item, podendo ter tanto natureza material, como imaterial; e v) as oportunidades perdidas, seja com a parte com quem se litiga ou com qualquer outro agente que esteja no mesmo contexto ou mesmo mercado, devido, por exemplo, à deterioração da relação ou a falta de recursos alocados ou gastos na disputa. ${ }^{353}$

\subsubsection{SATISFAÇÃO}

O segundo fator enumerado dos costs of disputing é a satisfação das partes com os resultados alcançados por meio do processo de solução de conflito. A satisfação é tanto um princípio, como um componente dos custos.

No exemplo do mineiro, que teve sua bota furtada e não foi atendido pelo empregador em seu pleito por outro calçado de trabalho e, por isso, incitou uma greve, a solução parcial alcançada com esta mobilização de força foi satisfatória para os mineiros? Utiliza-se o termo "solução parcial", por que, em si, a greve não solucionou o problema. Todavia, constituiu uma demonstração de força e permitiu aos mineiros que ventilassem suas emoções, em especial, o descontentamento com o a postura que a empresa tinha adotado até então. Além disso, fez com que as partes voltassem à mesa de negociação e, desta vez, solucionassem a disputa e o conflito de forma satisfatória, conforme seus interesses.

\footnotetext{
${ }^{353}$ Conforme WILLIAMSON, Oliver Eaton. Transaction cost economics: The governance of contractual relations. Jornal of law and economics, Vol. 22, No. 2 (Oct., 1979), p. 233.
} 
Cabe ressaltar que está englobada na satisfação a percepção de adequação, e, principalmente, de justiça. A percepção, entretanto, é uma operação com intensa carga subjetiva.

Isto compõe um desafio para o DSD: não basta que a solução seja objetivamente satisfatória, justa e adequada, ela também deve assim ser sentida pelos envolvidos. Isto é, para que haja a satisfação das partes com a solução, é necessário que elas tenham essa percepção. Para tanto, eventualmente, é necessário que sejam fornecidas às partes informações suficientes para que possam avaliar a solução alcançada, verificando seu grau de satisfação.

É possível que os sujeitos já tenham o conhecimento necessário para realizar tal avaliação. Caso contrário, todavia, a transmissão dessas informações deve estar prevista no desenho do sistema e ser feita de forma idônea. Por exemplo, pela análise do terceiro neutro em uma seção mediação ou conciliação avaliativa ou por meio de parâmetros referenciais baseados em índices legítimos, como jurisprudência. Esta técnica foi adotada nos casos da Câmara de Indenização Voo 3054 (CI3054) e Programa de Indenização Voo 447 (PI447), ${ }^{354}$ projetos que serão estudados na segunda parte desta dissertação.

A satisfação depende, em grande parte, de quanto do interesse inicial das partes, que originou a pretensão ou a resistência à pretensão, foi satisfeito na resposta dada ao conflito pelo sistema.

Como já analisado, a satisfação também depende do sentimento de justiça das partes em relação ao resultado. Por mais que não haja a satisfação plena dos interesses, ainda assim é possível que a parte tenha a percepção que o resultado alcançado é justo, estando assim, em alguma medida, satisfeito.

Essa percepção de justiça, não se limita ao resultado, atinge também o procedimento aplicado. Este fenômeno está relacionado a algumas características do mecanismo: quantidade e qualidade das oportunidades dadas às partes para poderem se manifestar; quanto Os sujeitos dos conflitos controle a parte tem para aceitar ou não um acordo, qual é a participação das partes na construção e modelagem da solução; e atuação 
imparcial e justa do terceiro, quando previsto no sistema. ${ }^{355}$ São elementos que remetem, mesmo que de forma relativa, ao contraditório, à ampla defesa e ao devido processo legal.

Por mais que se esteja referindo à satisfação das partes envolvidas no conflito, em determinados casos, pode ser necessário que essa análise seja estendida, em alguma medida, a um grupo mais amplo. ${ }^{356}$ Com a ampliação dos sujeitos, seriam alcançados também interessados que exercem influência sobre o sistema, cujo grau de satisfação repercute na dinâmica de solução do conflito.

A dinâmica proposta pelo método de desenho de sistema de solução de conflito, normalmente, funda-se em dois pilares consensuais, como se analisará de forma extensiva a seguir. ${ }^{357}$ De forma simplificada, inicialmente, há consenso quanto à adoção do método, posteriormente, pode haver o consenso quanto à solução para o conflito. Enquanto no segundo momento têm-se como sujeitos do consenso as partes conflitantes, ${ }^{358}$ no primeiro momento, de adoção do DSD e do sistema por meio dele criado, os sujeitos do consenso podem ser diversos das partes do conflito.

Nos casos nos quais há essa diferença, normalmente, para o desenvolvimento do mecanismo há um representante da coletividade em conflito ou alguma liderança institucional, como um sindicato, organização ou autoridade pública. Esse representante participa deste consenso de adoção do método, pois defende os interesses de seus representados, financia e/ou legitima o sistema. ${ }^{359}$ Este sujeito, apesar de não ser um dos polos do conflito, tem influência e interesse direto na construção e na aplicação do sistema, devendo, dessa forma, sua satisfação também ser considerada quando da análise dos custos.

Como ilustração, tem-se o administrador público ou mesmo um diretor de uma escola, responsáveis pela gestão dos recursos e financiamento de uma estrutura que busca

\footnotetext{
${ }^{355}$ URY, William L.; BRETT, Jeanne M.; GOLDBERG, Stephen B. Getting disputes resolved: designing systems to cut the cost of conflict. $1^{\text {a }}$ Ed. São Francisco: Jossey-Bass Publishers, 1988, p. 12.

${ }^{356}$ Como será analisa em QUEM SÃO OS ATORES (PLAYERS)?, p. 161, o grupo de indivíduos com interesse revelante no sistema é mais amplo que o dos sujeitos do conflito.

${ }^{357}$ OS DOIS CONSENSO, p. 83.

${ }^{358}$ Ainda nesta hipótese, pode-se pensar em representação, seja um advogado que represente a parte, seja um pai representando sua esposa e filho. Contudo, nestes casos, têm-se representantes que pleiteiam em nome alheio direito alheio, sendo que no exemplo do pai, este pleiteia também em seu próprio nome seu direito.

${ }^{359}$ Os sujeitos do conflitos e outros atores interessados são analisados no tópico QUEM SÃO OS ATORES (PLAYERS)?, p. 161.
} 
dirimir adequadamente eventuais conflitos entre alunos, professores ou entre estas duas classes. $^{360}$

Pontua-se, todavia, é possível que este ator, provedor de alguma espécie de recursos ao sistema, venha a figurar como um dos polos de um conflito específico. Ou seja, o diretor da escola, mencionado no exemplo, apesar de gestor do sistema, pode também ser um dos polos de um conflito, com um professor ou um aluno. Neste caso, devem ser previstos artifícios que consigam preservar a imparcialidade e adequação do sistema. Esse cuidado visa evitar que esse sujeito venha a ser ou aparente ser privilegiado pelo sistema do qual é provedor.

Outro exemplo que se pode levantar de interessados que exercem influência sobre o sistema de solução de conflitos, são aqueles sujeitos que, devido a sua situação perante a comunidade, dão ou incrementam a legitimidade do mecanismo. É o caso dos órgãos públicos, como o Ministério Público, Defensoria Pública, Fundação PROCON e Ministério da Justiça, que, entre outras funções, deram maior legitimidade à Câmara de Indenização Voo 3054 (CI3054) e Programa de Indenização Voo 447 (PI447), já mencionados e que serão analisados posteriormente. ${ }^{361}$

\subsubsection{EFEITOS DO MECANISMO E DE SEU RESULTADO NA RELAÇÃO CONFLITUOSA}

A via adotada para dirimir um determinado conflito, bem como a solução alcançada apresentam efeitos diretos na relação das partes e devem ser considerados quanto da análise dos costs of disputing.

\footnotetext{
${ }^{360}$ Este exemplo teve como base o caso da Bryant High School, em Nova York. Com problemas de tensão e violência, a escola instituiu um programa de mediação específicas para essa matéria no começo da década de 80. Alunos, professores, administradores e pais de alunos receberam intenso treino das técnicas de mediação. Esses novos mediadores auxiliavam na solução de conflitos dentre professores e alunos, entre alunos e seus pais e, até mesmo, brigas de mão entre os alunos. O número de suspensões caiu drasticamente e o ambiente escolar melhorou. Esse programa de sucesso estendeu-se a outras escolas, passando a ser adotado no âmbito nacional. URY, William L.; BRETT, Jeanne M.; GOLDBERG, Stephen B. Getting disputes resolved: designing systems to cut the cost of conflict. $1^{\mathrm{a}}$ Ed. São Francisco: Jossey-Bass Publishers, 1988, p. xiii.

${ }^{361}$ VOO TAM 3054 E VOO AIR FRANCE 447, p. 177. A Defensoria Pública do Estado do Rio de Janeiro não integrou o conjunto de autoridades públicas que participaram do Programa de Indenização Voo 447.
} 
Por um lado, é possível que haja o fomento do vínculo das partes, com a eleição de mecanismos construtivos ${ }^{362}$ de solução de conflito. Estes meios propiciam que a superação do conflito seja uma oportunidade de crescimento e de incremento da relação. Resultados adequados, que satisfaçam aos interesses destes sujeitos, também beneficiam a relação, funcionando como um troféu de uma atividade cooperativa bem sucedida. Uma mediação que consiga não só resolver, como também aumentar a comunicação entre as partes é um exemplo de mecanismo construtivo.

Por outro lado, também, é possível que o caminho adotado gere a deterioração desse liame. Isso pode ser consequência, por exemplo, de uma solução baseada em uma competição de poder, que, inevitavelmente, subjugará e maculará uma das partes com o estigma de perdedor.

Em regra, essas consequências para a relação atingem a habilidade das partes em conviver e, assim, sustentar uma relação saudável.

\subsubsection{REAPARIÇÃO DO CONFLITO}

Por fim, o fator reincidência da análise dos costs of disputing deve ser examinado tendo como base a efetividade da solução. Em outras palavras, verifica-se a durabilidade da solução alcançada por meio do sistema e se ela conseguiu dirimir, não só a disputa, mas também o conflito.

Assim, averígua-se se a solução perdurou ou se foi quebrada e por quais razões.

Neste ponto, é relevante que se analise o alcance da solução. Caso só tenha dissolvido a disputa ou, mesmo que tenha atingido o conflito, não o tenha solucionado adequadamente, é possível e provável que haja reincidência das animosidades.

362 Conforme estudos de Mary Parker Follet e análises nos tópicos RACIONALIDADE DOS MECANISMOS CONSENSUAIS, p. 61. FOLLETT, Mary Parker. Prophet of management: a celebration of writings from the 1920s. Beard Books, 1996, p. 67. 
Outro aspecto que deve ser objeto de análise, especialmente em relações continuadas, é se o vinculo existente entre as partes é naturalmente conflituoso. Em caso afirmativo, passa-se para novas etapas, levantando informações quanto à natureza desses novos conflitos. É importante que se saiba se os conflitos são homogêneos ou não e se o sistema existente é capaz de trata-los adequadamente ou passível de readequação, buscando ao mesmo tempo a prevenção e a solução dos conflitos emergentes.

Ilustrativamente, propõe-se o exemplo de uma empresa que adota um sistema de solução de conflitos buscando tratar os repetidos casos de assédio sexual. O mecanismo empregado, devido ao tema íntimo, trata com discrição os casos, restringindo cada processo apenas às partes envolvidas, obtendo, em regra, sucesso. Contudo, da forma que se desenvolve, esse sistema não atinge adequadamente os outros membros dessa comunidade, nesta hipótese, outros funcionários da empresa.

Assim, não se aproveita o caráter educativo da superação do conflito, não se impedindo que novos casos de assédio surjam. Com isso, mesmo que haja sucesso com as partes, não se consegue tratar a endemia existente nesta organização.

Essa reincidência de conflitos de mesma natureza, mesmo não havendo a repetição dos sujeitos, originam custos diversos para os trabalhadores e para a organização.

Eventualmente, tal problema poderia ser superado com a adição ao sistema de campanhas informativas direcionadas aos funcionários, ou seja, com a oferta de recursos técnicos.

\subsubsection{CUSTO: INTERESSE, REGRA, PODER}

As soluções construídas por meio de mecanismos baseados em interesse têm menor costs of disputing. Isto porque, atendem aos interesses das partes, satisfazendo-as e afastando ou, ao menos, diminuindo significativamente a reincidência. Sua dinâmica 
procedimental, baseada na busca pelo consenso, incrementa a relação das partes devido à comunicação e cooperação. ${ }^{363}$

Já quanto aos custos de transação, constata-se a existência de algumas ponderações que devem ser apresentadas. Partindo de um exemplo simples, os custos de transação de um procedimento de "cara ou coroa" para solucionar um conflito são mínimos. É uma técnica rápida, de baixa exigência de recursos. A princípio, bastam uma moeda e um terceiro, para jogá-la e proclamar o resultado, não sendo vital prática, tampouco experiência. Apesar disso, atinge criticamente os outros pilares dos costs of disputing, como a satisfação e sua percepção de justiça ou os efeitos construtivos na relação das partes. Como já foi posto, os componentes do custo devem ser analisados de forma global, ponderando os resultados das suas diferentes interações. É notório que, comparativamente, por exemplo, uma mediação dure mais tempo e necessite de maiores recursos.

Por sua vez, as soluções baseadas em regras ou poder, isto é, que busquem a definição de quem está certo ou quem é mais forte, acabam apontando um ganhador e, consequentemente, um perdedor. Isto faz com que a relação torne-se mais adversarial e menos cooperativa. Normalmente, o perdedor fica insatisfeito com a solução, acabando por não colaborar com o seu cumprimento. Isso tende a gerar recursos, agregando novos procedimentos, etapas, instâncias. Estas são algumas consequências de mecanismos baseados no "ganha-perde". 364

Comparando sistemas baseados em regra e poder, observa-se que uma competição visando determinar qual parte é mais forte acarreta maior consumo de recursos e maior número de chances perdidas. ${ }^{365}$ Greves, duelos, lutas têm custos maiores que arbitragens, processos judiciais. Não são custos relacionados apenas com os esforços investidos para a luta, mas também, a destruição causada a cada um dos lados envolvidos.

\footnotetext{
${ }^{363}$ URY, William L.; BRETT, Jeanne M.; GOLDBERG, Stephen B. Getting disputes resolved: designing systems to cut the cost of conflict. $1^{\text {a }}$ Ed. São Francisco: Jossey-Bass Publishers, 1988, p. 14.

${ }^{364}$ RACIONALIDADE DOS MECANISMOS CONSENSUAIS, p. 61.

${ }^{365}$ São perdidas chances de relacionar positivamente com o adversário ou de se relacionar com terceiros, por se estar ocupado em uma disputa de força ou por não ter recursos, que foram alocados ou consumidos pelo confronto. Essa análise das chances perdidas é válida para o perdedor e inclusive para o vencedor.
} 
Além disso, os mecanismos de solução de conflito baseados na força acabam gerando novos danos e novos conflitos ao longo da luta, irrigados com fortes emoções, como raiva, desconfiança e desejo de vingança.

Contudo, apesar das vantagens, nem sempre solucionar um conflito por meio da conciliação de interesses é possível ou desejável para todos os conflitos. ${ }^{366}$

Eventualmente, o uso de mecanismos baseados em regras ou força pode ser necessário. Como, por exemplo, para trazer à mesa de negociação uma parte que resiste ou para fazer com que se cumpra um acordo ou uma decisão.

Ademais, os sujeitos podem ter perspectivas muito discrepantes de quem é mais forte ou está certo. Dessa forma, não conseguem estabelecer um panorama, entender o ambiente, contextualizar o conflito para poderem negociar.

Vias como a opinião neutra de terceiro, a arbitragem não vinculante ou a mediação ou conciliação avaliativa podem esclarecer às partes sobre suas forças e seus direitos, auxiliando-as na escolha da melhor "jogada" e, portanto, na negociação.

Mecanismos baseados em interesse não são viáveis em casos nos quais as partes têm interesses diretamente opostos, já que isso torna o consenso impossível, por impedi-las de encontrar alguma intersecção entre suas esferas de interesse. Como exemplo, pode-se pensar, no contexto norte americano, nas clínicas de aborto e nos grupos religiosos que defendem de forma absoluta o direito de viver, que se enfrentam nas cortes e nas casas legislativas.

Em outras hipóteses, apesar da possibilidade de se solucionar o conflito com base no interesse, é desejável, eventualmente, por ser mais adequado, que se use mecanismos baseados em regras para definir quem está certo ou mecanismos baseados em poder.

\footnotetext{
${ }^{366}$ Conforme URY, William L.; BRETT, Jeanne M.; GOLDBERG, Stephen B. Getting disputes resolved: designing systems to cut the cost of conflict. $1^{\mathrm{a}}$ Ed. São Francisco: Jossey-Bass Publishers, 1988, p. 15.
} 
Para questões de importância pública, cuja solução pode se gerar exemplos antecedentes ou efeitos que extrapolem os envolvidos, o uso de mecanismos baseados em regras pode ser mais adequados. Exemplo muito pertinente é o caso Brown versus Board of Education. ${ }^{367}$ Ele, justamente pelo processo ter alcançado a Suprema Corte, gerou efeitos maiores do que se tivesse sido resolvido por meio de uma negociação local baseada em interesse.

Neste ponto, contudo, cabe a reflexão sobre o quão diversos são os efeitos para a coletividade do resultado determinado pela Suprema Corte americana e de um possível acordo feito entre as autoridades locais de educação e os demandantes.

Esse acordo ilustrativo também teria o condão de servir como exemplo para outras regiões americanas. O feito poderia repercutir, pela mídia ou por alguma outra via, com potencialidade de atingir efeitos semelhantes aos da decisão da corte. Ademais, isso seria feito a um custo muito menor. Contudo, são apenas suposições, não sendo certo o grau de repercussão que concretamente se poderia atingir.

O impacto social da decisão da corte, por sua vez, apresenta-se com menor grau de oscilação. Apesar disso, o sistema judicial, neste exemplo, tende a ser mais custosa.

A ilustração permite constatar que se trata de uma questão de grau, devendo ser analisado o caso concreto para verificar a via mais adequada.

Quando a disparidade de força entre as partes for grande, haverá uma tendência, implementada pelo mais forte, que se use mecanismos baseados em poder, apesar dos custos. Essa hipótese exige reflexão cautelosa, por se localizar em região limítrofe do legal, ético e economicamente viável. Apesar da eventual aparência abusiva, a força tem legitimidade social, por exemplo, na relação de pais e filhos e professores e alunos.

\footnotetext{
${ }^{367}$ PITTS, David. Brown contra a secretaria de educação [Brown v. board of education]: a decisão da suprema corte que transformou um país. Disponível em http://usinfo.state.gov/journals/itdhr/0999/ijdp/pitts.htm
} 
Além disso, periodicamente, a parte poderosa deverá evidenciar sua força, por meio de ameaças e sempre se protegendo de possíveis revanches. Estas, muito provavelmente, viriam de forma pequena, compatível com a força da parte mais fraca, causando problemas e aborrecimentos para a outra parte.

Ademais, a imposição pelo sujeito mais forte de determinada conduta que pode estar além das forças da outra parte, possivelmente culminará na inadimplência, no fracasso do acordo, do decidido ou do imposto. Dessa forma, deverá à parte poderosa implementar procedimentos para a averiguação do cumprimento, o que gerará custos. Eventualmente, terá que executar tal acordo ou determinação pela força, com a possibilidade de não obter êxito, ou por via baseada em regras, na qual, poderá ter sua imposição, como eventual acordo, questionada quanto a sua legalidade, e, também, não lograr sucesso.

Propõe-se a seguinte reflexão: considerando um ente fictício que tenha conduta racional e que apresente força absoluta e, dessa forma, não se submeta e nem dependa de nada e nem de ninguém, em um contexto no qual o Estado ou qualquer figura que o valha para limitar suas conduntas inexista, em quais hipóteses esse ente utilizar-se-ia de mecanismos consensuais baseados em interesse?

Em um primeiro momento, parece claro que em nenhuma hipótese ele se submeteria ao interesse alheio. Contudo, apesar do conflito, é possível que existam, no interesse alheio, vetores congruentes ao seu. Isso significa que as esferas de interesses interseccionam-se em alguma medida, o que viabilizaria o consenso.

Dessa forma, caso este ente entenda que eventual cooperação com o interesse do outro sujeito gere benefícios a si próprio como, por exemplo, reduza seus custos, fomente sua atividade, em suma, reduza suas perdas e aumente seus ganhos, ele poderá utilizar-se de meios consensuais e de interesse para sanar seus conflitos com partes mais fracas. Alcança-se um bem comum, por meio de interesses egoísticos. 


\subsection{ASPECTOS ESTRUTURAIS DO SISTEMA}

Os sistemas de solução de conflito provenientes do DSD são um arranjo de elementos e atividades dispostos de forma tal a compor uma unidade com funcionalidade $\mathrm{e}$ finalidade própria. Assim como um motor de automóvel, cujas peças, isoladamente consideradas, não têm a capacidade de mover o carro, é necessário que estes elementos sejam organizadamente relacionados para que o sistema funcione e consiga desempenhar seu fim.

A mencionada finalidade, por exemplo, é um dentro de um conjunto de aspectos estruturais básicos integrantes dos sistemas de solução de conflito.

É sobre essas partições que o princípio da adequação e especialmente as técnicas basilares do DSD são implementados. Essa aplicação ocorre direta e individualmente em cada um desses componentes integrantes do mecanismo, como também na estrutura formada pela união deles. Com a relação entre o princípio, as técnicas e os elementos, ocorre a organização para o funcionamento harmônico do sistema.

Considerando essa interação, entendeu-se que a análise prévia dos principais aspectos estruturais do mecanismo tornaria o estudo das técnicas mais frutífero.

Além disso, o domínio deles colabora com a compreensão da natureza dos sistemas de solução de conflitos desenhados e, por conseguinte, da sua criação e de seu funcionamento.

Antes de se iniciar a enumeração e análise desses aspectos dos sistemas de solução de conflitos desenhados a partir do método do DSD, é necessário que se faça a ressalva quanto ao conjunto abordado. A delimitação ora adotada não exclui a existência, nem invalida contornos diversos. ${ }^{368}$ Entendeu-se, contudo, que a enumeração que segue é a

\footnotetext{
368 A enumeração dos aspectos estruturais de um sistema de solução de conflito pertence ao campo da taxonomia. Classificam-se características que são agrupadas conforme determinado critério, permitindo, assim, que existam variações, que, apesar de distintas, permanecem válidas. Francis Mcgovern e Cathy Costantino e Christina Merchant apresentam não só apresentam rol, como distintos dos elementos dos sistemas de solução de conflito. Enquanto Cathy Costantino e Christina Merchant enumeram seis características: boundaries, purpose, inputs, transformation, outputs e feedback, (COSTANTINO, Cathy A.; MERCHANT, Christina Sickles. Designing conflict management systems. $1^{\text {a }}$ Ed. São Francisco: Jossey-Bass, 1996, p. 24), Mcgovern, por sua vez, enumera nove elementos: i) function, ii) metaphor, iii) authority and
} 
mais útil para o presente estudo, tendo em vista os casos analisados e os autores idealizadores do DSD.

Tendo em vista essas ponderações, entende-se que os mecanismos de solução de conflitos criados a partir dos fundamentos e técnicas do DSD apresentam como aspectos principais, os seguintes: i) finalidade, ii) limites, iii) insumos (inputs), iv) transformação, v) resultados, produtos (outputs) e vi) análise da reação à atividade e avaliação do sistema (feedback).

\subsubsection{FINALIDADE}

Todo mecanismo, sistema, processo tem o seu propósito. Isso se deve ao fato de a finalidade ser inerente aos instrumentos. Ela, entre outros aspectos, norteia a criação e o uso destes pelos sujeitos.

Todo e qualquer sistema desenhado com base no DSD tem como fim processar e solucionar adequadamente um determinado conflito para o qual foi moldado. Todavia, este é um fim genérico, abstrato, distante, último.

Conforme se altera a perspectiva da análise, aproximando-se do objeto, revelam-se novas finalidades ou novos conjuntos de finalidades.

Como cada um desses sistemas de solução de conflito são idealizados e desenhados para trabalhar com uma determinada espécie de conflito, além dos fins remotos, existem também fins próximos, que se relacionam diretamente com o objeto conflituoso e seus diferentes aspectos. Logicamente, há compatibilidade dos fins próximos e concretos com o fim remoto traçado pelo DSD, ou seja, com o adequado tratamento e solução do objeto conflituoso.

Ilustrativamente, propõe-se o exame de um sistema fictício com a finalidade de solucionar os conflitos provenientes de um dano ambiental específico. É possível constar que essa finalidade, por meio de uma observação mais próxima, é um conglomerado de

funding, iv) size and similarity, v) organization, vi) eligibility criteria, vii) damage methodology, viii) compensation, ix) Iimplementation. MCGOVERN, Francis E. The what and why of claims resolution facilities. Standford Law Review, Vol. 57, April 2005, p.1362. 
partições mais específicas. Entre estas, pode constar a solução de questões quanto à legitimidade, criando critérios e verificando a legitimidade dos pleiteantes; como também definir como a indenização será calculada, por meio de compensações pecuniárias ou por obrigações de fazer reparatórias; ainda, estabelecer o quantum a ser pago ou determinar a conduta necessária; concretizar a efetiva indenização, pagando o valor ou verificando o cumprimento da conduta acordada ou determinada.

Como se ilustrou por meio da imagem do motor, há uma natural interação entre os elementos, que é necessária para que o sistema funcione harmonicamente. Com isso, um sistema que tenha como fim apenas compensar pecuniariamente terá estrutura diversa de um sistema que vise apurar o dano ambiental, repará-lo, por exemplo, por meio de condutas despoluidoras ativas e, por fim, ainda averiguar a efetiva recuperação do meio ambiente.

Suscintamente, este segundo sistema, que tem que completar um maior número de metas, exigirá um maior número de insumos, como recursos financeiros, técnicos e humanos.

\subsubsection{LIMITES}

Considerando que os sistemas provenientes do DSD têm por finalidade o adequado tratamento e solução do conflito para os quais foram criados, têm-se os conflitos como objetos destes mecanismos.

Contudo, situações concretas exigirão informações mais detalhadas e farão com que surjam perguntas como "até onde vai o conflito?", “quais são os aspectos do conflito e quais serão trabalhados pelo sistema de solução de conflito?", “quem são os sujeitos do conflito?", "existem outros sujeitos com interesse relevante ou com influência sobre sistema?", 369 "o que faz parte e o que não faz parte do sistema?”.

\footnotetext{
369 A questão “existem outros sujeitos com interesse relevante ou influência no sistema?" é tratada introdutoriamente quando da análise dos limites subjetivos. Realiza-se um estudo mais detalhado da indagação e suas respostas no tópico QUEM SÃO OS ATORES (PLAYERS)?, p. 161.
} 
Para perguntas desta natureza existem os limites do sistema. Eles são as fronteiras do sistema e demarcam a área, os sujeitos e os objetos que o compõem ou não. Dessa forma, este elemento estrutural apresenta-se em três perspectivas: física, objetiva e subjetiva.

Os limites físicos, tangíveis ou não, posicionam o sistema desenhado no ambiente. Expressam a proximidade do sistema em relação a outros, ${ }^{370}$ distinguindo-o ou agregando-o a eles. Por fim, ainda estabelecem quais e como ocorrerão as relações entre eles.

Sistemas criados para gerenciar os conflitos de uma determinada organização, ${ }^{371}$ por exemplo, costumam estar contidos ou próximos dos departamentos pessoal e/ou jurídico. Assim, facilita-se a alocação de recursos, inclusive dos recursos humanos, como psicólogos e advogados.

Aproveitando o exemplo dado e utilizando a racionalidade dos conjuntos, propõe-se a construção de um panorama deste ambiente para auxiliar no entendimento do tema. O sistema de solução de conflito, o sistema do departamento jurídico e o sistema do departamento pessoal podem ser vistos como grandes conjuntos que se interseccionam e, desse modo, têm os seus elementos próprios e seus elementos comuns. Estes três conjuntos, no exemplo dado, fazem parte de um círculo ainda maior, a organização na qual se encontram. Dentro da organização, além dos três sistemas mencionados, existem diversos outros, que se interseccionam ou não, mas, que, de alguma forma, relacionam-se.

É importante que se tenha essa imagem e que se esteja ciente que o sistema desenhado com base no método do DSD não se encontra sozinho no espaço. ${ }^{372}$ Está em um ambiente repleto de outros sistemas. Quanto a alguns, o mecanismo de solução de conflito será indiferente, quanto a outros, terá que considerá-los. Isso porque, é possível que, parte dos insumos e dos produtos do sistema, como os conflitos e suas soluções, tenham origem e destino nos sistemas próximos, como os diversos outros campos da organização.

\footnotetext{
${ }^{370}$ Estes sistemas vizinhos podem ou não ter natureza de mecanismo de solução de conflito.

${ }^{371}$ O "termo" organização é utilizado em seu sentido amplo, podendo ser, por exemplo, uma empresa, escola ou alguma entidade pública.

372 "We have learned to see legal institutions as part of larger ecology in which various dispute institutions interact and affect one another". GALANTER, Marc. Compared to what? Assessing the quality of dispute processing. In: Denver University Law Review, n. 66, 1988-1989, p. XI.
} 
Essa interação entre sistemas estava prevista nos mecanismos desenhados para os casos dos acidentes aéreos da TAM e Air France, que serão analisados. ${ }^{373}$ Os respectivos sistemas interagiam com os órgãos do Sistema Nacional de Defesa do Consumidor, bem como com os sistemas das companhias aéreas. O destaque ao elemento dos limites físicos ocorre, pois há clara sobreposição de áreas entre os sistemas. Estas fronteiras, por exemplo, expressavam com quais órgãos estatais os sistemas de solução de conflito tinham vínculos e como se davam os fluxos de comunicação.

Além da perspectiva de interação dos sistemas, quanto à topologia, o sistema deve se encontrar, idealmente, em campo neutro, equidistante das partes.

Ao conhecer os limites, as partes têm os dados necessários para que possam avaliar essa equidistância ou mesmo as ligações existentes entre o mecanismo e os sujeitos do conflito. Essa ciência adquire especial importância nas hipóteses de disparidade de armas ou manifesta proximidade do mecanismo a um dos polos do conflito.

O fato de as partes estarem informadas se há algum poder de interferência sobre o sistema e em que medida isso ocorre, colabora para que o procedimento e a solução sejam e pareçam justos e satisfatórios, o que, em uma última análise, reflete-se na adequação do sistema.

Em um sistema indenizatório, por exemplo, é de se esperar que o causador do dano, parte do conflito, seja também o responsável pelo custeio do sistema. Mas, para que isso não implique um mecanismo tendencioso ou com aparência de sê-lo, é importante que os pleiteantes tenham ciência sobre a existência da gerência ou ingerência do financiador do mecanismo.

Esses limites, quando da criação do sistema, devem ser traçados visando resguardar e contribuir com o propósito do mecanismo. Posicionar o sistema integralmente dentro do "território" de uma das partes tende a prejudicar a equidistância ou, ao menos, a sensação de isonomia e justiça da outra parte em relação ao procedimento e eventual solução, comprometendo a adequação do sistema.

${ }^{373}$ VOO TAM 3054 E VOO AIR FRANCE 447, p. 177. 
Os limites objetivos, por sua vez, estabelecem a matéria conflituosa com que o sistema trabalhará, isto é, o conflito pertinente para o sistema.

A adequação do mecanismo, em seu plano objetivo, ${ }^{374}$ está diretamente relacionada com os limites objetivos, uma vez que é auferida tendo o objeto conflituoso como parâmetro.

O sistema pode ter sido criado, por exemplo, para solucionar todo e qualquer conflito que venha a surgir entre alunos de uma determinada escola ou restringir-se a indenizar, moral e materialmente, um determinado acidente aéreo.

Considerando os conflitos complexos, em uma perspectiva ideal, os sistemas provenientes do DSD deveriam ter como objeto todos os aspectos do conflito aos quais foram moldados.

Por outro lado, por meio de uma análise crítica e realista, não se pode negar a possibilidade de ser inviável, devido a custos excessivos, que o sistema trate plenamente todos os aspectos do conflito e ainda possa ser qualificado como adequado. Essa problemática tende a decorrer de desafios fáticos relacionados, entre outros, a recursos técnicos ou a aquisição de informação.

A emoção, os traumas e outras questões de cunho psíquico são aspectos presentes em conflitos provenientes de acidentes aéreos, por exemplo. Um sistema de solução de conflito que busque solver conflitos referentes à indenização pode não ter entre seus objetos principais estes aspectos. Nada impede, contudo, que este mecanismo faça parte de um sistema maior que tenha uma partição específica para estas questões, com recursos técnicos e humanos, como psicólogos e médicos, voltados para atender adequadamente estas questões.

Por fim, antes que se passe para a análise dos limites subjetivos, cabe destacar mais uma interação entre os aspectos. Os insumos (inputs), que ainda será analisado, são delimitados abstratamente pelos limites objetivos. Os recursos empregados pelos sistemas têm que corresponder à matéria conflituosa que se pretende tratar. Além disso, entre os

\footnotetext{
${ }^{374}$ PRINCÍPIO DA ADEQUAÇÃO, p. 99.
} 
recursos do sistema, encontram-se os conflitos, que serão transformados e darão origem a produtos.

Por fim, os limites subjetivos definem as partes legitimadas ${ }^{375}$ a trazer seu pleito àquele sistema.

Esta delimitação é feita por meio de critérios de legitimidade previstos pelo sistema. Dessa forma, por exemplo, podem ser legítimos sujeitos e trabalhadores de uma determinada organização ou, como ocorreu na CI3054, apenas os que sofreram danos indenizáveis relacionados a vítimas fatais, mas que ainda não haviam sido indenizados. ${ }^{376}$

Dentro de organizações, como escolas e empresas, a definição dos limites subjetivos não costuma implicar altos custos. Isto porque, considerando a existência de um cadastro de membros, por meio de um procedimento simples, é possível o levantamento das pessoas legitimadas, como professores, alunos e colaboradores.

Em uma tragédia aérea, sem vítimas fatais, existindo uma lista oficial e correta de passageiros e tripulantes, a identificação das vítimas diretas do acidente e legítimas para eventuais indenizações também não gera custos elevados.

Contudo, aspectos do conflito podem dificultar a definição dos limites subjetivos. Como ocorre em acidentes com vítimas fatais. Nesta hipótese, perdem-se os indivíduos atingidos primariamente pelo fato. Assim, passa-se aos respectivos beneficiários, dependentes econômicos das vítimas e os lesados moralmente com os falecimentos. Contudo, este rol, em regra, é desconhecido pelo sistema e sua determinação acarreta custos.

\footnotetext{
${ }^{375}$ A qualidade de parte legitima é apurada com a análise da relação conflituosa e, dentro de um sistema jurídico, do direito material. Para que as partes sejam ativa ou passivamente legítimas é necessário que exista um vínculo entre estes sujeitos e a "situação jurídica afirmada, que thes autorize a gerir o processo em que esta será discutida". (DIDIER JR., Fredie. Curso de direito processual civil. Vol. I. 15 ${ }^{\mathrm{a}}$ Ed. Salvador: Editora Juspodivm, 2013, p. 238). A princípio, as partes legítimas são os sujeitos da relação jurídica de direito material, ou seja, os sujeitos da relação conflituosa. Além disso, como pondera Cândido Rangel Dinamarco, não há que se vincular necessariamente a condição de parte, sujeito da relação processual, com a condição qualificada de parte legítima, que decorre do dever-ser. (DINAMARCO, Cândido Rangel. Instituições de direito processual civil. Vol. II. $5^{\text {a }}$ Ed. São Paulo: Malheiros Editores, 2005, p. 117).

${ }^{376}$ Conforme artigo 13, Capítulo VI - Legitimidade, do Regimento Interno - Câmara de Indenização Voo 3054, p. 10.
} 
Apesar da ignorância, são possíveis suposições quanto a estes beneficiários, tanto em relação à sua existência, como à sua determinação: é provável que existam familiares e que estes sejam beneficiários. Estas conjecturas têm base em máximas de experiência e servem como guias para a obtenção destas informações.

Todavia, por mais que estas deduções possam ser feitas em abstrato, não resolvem a falta de informações no plano fático. Em concreto e em um primeiro momento, não se sabe se existem ou quem são estes indivíduos.

O levantamento destas informações, na busca da definição dos limites subjetivos, pode se dar de alguns modos, implicando sempre, em alguma medida, custos.

Essa aquisição de informações pode ocorrer mediante a conduta ativa do sistema, pesquisando os dependentes econômicos e os atingidos moralmente com os falecimentos. O movimento que tende a prevalecer nestes casos, entretanto, é outro. A tendência é que o sistema seja procurado pelos indivíduos que entendem ser legítimos para receber a indenização. Estes deverão provar esse fato, isto é, a qualidade de legítimos para pleitear a indenização, conforme os critérios do sistema.

Alguns terão sua legitimidade apurada com menor custo, como os pais, irmãos, filhos, esposos, cujos estados são facilmente aferidos por documentos oficiais, como certidões de nascimento e casamento.

Os custos serão maiores, contudo, na hipótese de vínculos, patrimoniais ou afetivos, não formalizados ou não passíveis de registro oficial, como os de união estável, noivos, namorados, babás, afilhados, amantes, filhos fora do casamento, união homo afetiva. A dificuldade na comprovação dessas relações que justificariam eventuais indenizações eleva os custos da produção probatória e do estabelecimento dos limites subjetivos. 
Além disso, principalmente nas hipóteses de menor clareza, os beneficiários podem desconhecer a existência de outros referentes à mesma vítima, como também pode ser do seu interesse omiti-los. ${ }^{377}$

Uma esposa beneficiária pode desconhecer a existência de uma amante ou de um filho fora do casamento. Eventualmente, mesmo que saiba, pode ter o interesse de ocultá-los por razões morais ou econômicas, visando evitar uma eventual desonra ou que a indenização seja repartida, por exemplo.

Durante o desenho, é imprescindível que se tenha ciência desses aspectos, desafios e riscos. Como resposta, devem ser estipuladas estruturas que coíbam tais condutas, como por meio de declarações que formalizem e responsabilizem indivíduos que tenham se beneficiado indevidamente ${ }^{378}$ em detrimento de outros.

Ainda quanto às problemáticas da definição dos limites subjetivos, propõe-se que se reflita sobre um último caso, os atentados de 11 de setembro às torres gêmeas do World Trade Center em Nova York. Frente à magnitude da tragédia, como fazer o levantamento das vítimas fatais, considerando que nem todos os corpos foram encontrados? Mesmo quanto às vítimas sobreviventes, é possível, por exemplo, que um mero transeunte que se encontrava nas imediações do prédio tenha sido vítima quando do colapso das torres. O desafio é ainda maior, o que acaba por se refletir no acréscimo de custos. $^{379}$

\footnotetext{
377 Estes interesses de ocultar outros possíveis beneficiários não são considerados válidos dentro da nossa ordem jurídica. Contudo, é possível que não sejam sempre dessa forma considerados, a depender do conjunto normativo que venha a ser aplicado pelo sistema. Tendo em vista ainda a possibilidade de sistemas puramente baseados em interesse, como já estudado no tópico INTERESSE, REGRA E PODER: BASES DA SOLUÇÃO DE CONFLITOS, p. 37, não há parâmetros para a qualificação destes interesses como regulares ou não, devendo, ser valorados entre o conjunto de interesses das partes.

${ }^{378}$ Para que a via seja considerada "irregular", pressupõem-se a existência de um conjunto normativo ou o confronto com o interesse de outro sujeito do conflito. Destaca-se que, por mais que se possa apregoar um sistema baseado em interesse, no plano real, é pouco provável que ele apresente-se puro. Tende a estar presentes traços de sistemas baseados em regras e força, conforme INTERESSE, REGRA E PODER: INTER-RELAÇÃO, p. 45.

${ }^{379}$ Robert M. Ackerman realiza um estudo sobre o Sistema de solução de conflito aplicado aos ataques de 11 de setembro. ACKERMAN, Robert M. The September 11th victim compensation fund: an effective administrative response to a national tragedy. Harward Negotiation Law Review, v. 10, spring 2005. Ver também: FEINBERG, Kenneth R. What is Life Worth?: The Unprecedented Effort to Compensate the Victims of 9/11. Public Affairs, 2005.
} 
É possível abrandar os critérios de legitimidade, diminuindo seus custos na determinação dos limites subjetivos, com o risco de, por exemplo, indenizar um beneficiário que não era legítimo.

Por outro lado, é possível enrijecer esses critérios e a análise da legitimidade, aumentando a certeza e os custos desse processo de verificação dos legitimados. Como efeito colateral deste maior rigor, pode se excluir do sistema algum beneficiário legítimo, mas que não conseguiu provar sua legitimidade. ${ }^{380}$

Nas duas hipóteses, há possibilidade de flagrante injustiça, o que pode prejudicar a satisfação das partes com o procedimento e, assim, diminuir a adequação do sistema.

O grau de rigor ou flexibilidade dos critérios de legitimidade será estabelecido pelo designer e pelas partes, em correspondência às peculiaridades do conflito.

\subsubsection{LEGITIMIDADE}

A legitimidade do sistema é outro aspecto importante e pode ter origem em uma lei, uma norma administrativa, um tratado internacional, um processo de falência, ser uma oferta de uma das partes, as possibilidades são vastas. Essa origem, muitas vezes, é a responsável por estabelecer a legitimidade e autoridade do sistema frente aos sujeitos, partes ou interessados. ${ }^{381}$

Estes elementos interferem no desenho e no funcionamento do programa. ${ }^{382}$ Por exemplo, quanto mais próximas as autoridades governamentais estiverem do sistema,

\footnotetext{
${ }^{380}$ MCGOVERN, Francis E. The what and why of claims resolution facilities. Standford Law Review, Vol. 57, April 2005, p. 1371.

${ }^{381}$ MCGOVERN, Francis E. The what and why of claims resolution facilities. Standford Law Review, Vol. 57, April 2005, p. 1366.

382 "Another critical aspect for achieving legitimacy is defining the problem or audience that will make the dispositive determination of success or failure. Is the goal to please the world or a single country? Political leaders or the entire populace? Opinion leaders or the affected beneficiaries? Objectors or acceptors? Who, indeed, are the players in the 'legitimacy game', and what type of resistance will be created? [...] The critical issue is to identify the relevant public and to establish short-and long-term goals for achieving
} 
maior será a sua legitimidade, tendo em vista a natural legitimidade do Estado. Quanto mais obscura for a origem dos recursos financeiros, por exemplo, maior será a dificuldade para que o sistema tenha legitimidade própria. Quanto mais estatal for a origem dos recursos, mais tolerável se torna a imposição de limites às indenizações. Por outro lado, quanto mais privado for a origem, menos tolerantes serão os beneficiários com a ideia de terem alguma forma de abatimento nos valores, buscarão indenizações integrais.

\subsubsection{INSUMOS (INPUTS)}

Os insumos (inputs) são os recursos, provenientes de diversas fontes, absorvidos pelo sistema para que este atinja seu propósito. Estes insumos serão transformados e darão origem aos produtos do sistema, conforme será retomado quando da análise da transformação e dos produtos.

Em um rol exemplificativo, pode-se apontar a existência dos recursos financeiros, humanos, técnicos.

Os próprios conflitos não só são considerados matéria-prima, como são essenciais, juntamente com os recursos financeiros e técnicos.

Esta imprescindibilidade dos conflitos é decorrência da própria finalidade dos sistemas de solução de conflito. Este objeto conflituoso entrará no sistema, será processado, juntamente com os outros insumos, e, a princípio, originará uma solução como produto. A inexistência desse recurso impossibilita o mecanismo de cumprir seu propósito, tornando-o inútil e sem razão de ser.

A essencialidade dos recursos financeiros e técnicos é decorrência de necessidades fáticas do sistema. É importante saber, por exemplo, qual é a fonte de recursos financeiros que irão custear a criação e a manutenção do mecanismo, sob o risco de este não existir ou não perdurar. Já os recursos técnicos proverão ao sistema a

acceptance". MCGOVERN, Francis E. The what and why of claims resolution facilities. Stanford Law Review, Vol. 57, April 2005, p. 1377. 
possibilidade de serem desenhados e funcionarem adequadamente e, assim, gerarem produtos adequados. ${ }^{383}$

Os insumos são reflexamente delimitados pelos limites, uma vez que estes delimitam o sistema como um todo. Os limites físicos, por exemplo, estabelecem a origem destes recursos. Por sua vez, os limites objetivos definem os objetos conflituosos considerados como insumos.

\subsubsection{TRANSFORMAÇÃO}

A transformação é a atividade pela qual os insumos são fundidos pelos sujeitos e pelas técnicas do sistema e convertidos em produtos estáveis ${ }^{384}$ e adequados.

Ela a atividade processual, interagindo diretamente com o conflito na busca pelo seu tratamento e solução. Tanto essa interação, como essa solução devem ser adequadas à luz do ideário apresentado pelo DSD. Considerando sistemas consensuais, por exemplo, as tratativas dos sujeitos do conflito visando à composição encontrar-se-ão na transformação.

A atividade de transformação é guiada pela finalidade, tanto a genérica, de processar e solucionar adequadamente o conflito, quanto à concreta, por exemplo, indenizar.

\subsubsection{PRODUTOS (OUTPUTS)}

Os produtos resultantes da transformação dos insumos são exportados para o ambiente externo ao sistema. Tendo em vista que estes sistemas têm como fim a solução de

\footnotetext{
${ }^{383}$ No tópico QUEM SÃO OS ATORES (PLAYERS)?, p. 161, este tema referente aos recursos é retomado, contudo, a análise recairá sobre os provedores destes insumos.

${ }^{384}$ De forma semelhante à terminologia processual usada, por exemplo, em "estabilização da demanda" ou "estabilização da decisão", ao utilizar "produtos estáveis", busca-se apresentar a tendência de imutabilidade deste produto, solução, seja pela satisfação das partes ou por regras processuais estabelecidas pelo mecanismo ou pelo ordenamento jurídico.
} 
conflitos, tais produtos tendem a ser o fim do conflito, concretizando-se na forma de acordos ou decisões adjudicadas, por exemplo. Os produtos e suas formas variam conforme o sistema aplicado.

Em um plano ideal, considerando que os sistemas de solução de conflitos provenientes do DSD propõem-se como os mais adequados para o tratamento e solução do conflito em relação aos quais foram moldados, não só seria impossível que o produto fosse uma não solução, ${ }^{385}$ como também seria impossível uma solução diversa da mais adequada.

Cabem, todavia, ressalvas a essas afirmações.

Primeiramente, o DSD trabalha, de forma geral, com as diferentes formas básicas de solução de conflito, isto é, interesse, regra e poder, propondo que mecanismos baseados nelas sejam dispostos de forma escalonada. Dessa forma, o método visa evitar a não solução do conflito, como também conter os custos e, assim, manter a adequação do sistema. O objeto do presente estudo, no entanto, está limitado aos sistemas consensuais, não considerando o escalonamento mencionado em sua integralidade.

Além disso, a segunda ponderação que se propõe é quanto à causa dessa não solução dentro do campo dos mecanismos consensuais. ${ }^{386}$ Ela pode ser consequência não de uma inadequação do sistema, mas sim da impossibilidade fática de uma solução consensual.

A solução consensual ocorre com a congruência de vontades. Sendo assim, caso não haja intersecção entre as esferas de interesse dos sujeitos, não há ponto em comum, o que impossibilita o consenso.

\footnotetext{
${ }^{385}$ Por mais que semelhante à vedação do princípio do non liquet, não se utilizou a expressão, por ela ser compatível apenas com mecanismos adjudicatórios, não sendo possível sua extensão aos consensuais. O non liquet vem da expressão latina iuravi mihi non liquere, atque ita iudicatu illo solutus sum, com base na qual o julgador se eximia de proferir decisão frente à falta de clareza. Sua vedação encontra-se atualmente no artigo 126 do Código de Processo Civil.

386 Questão já analisado no tópico O PROBLEMA DA EFETIVIDADE DOS MECANISMOS CONSENSUAIS, p. 88.
} 
Por outro lado, em uma perspectiva realista, cabe ainda adicionar que, apesar de indesejável, é plausível que o sistema apresenta falhas, inadequações, das quais poderão resultar tratamentos ou soluções inadequadas ou diversas da mais adequada.

Quanto à vinculação das partes ao produto, a princípio, dar-se-ia simplesmente em decorrência da satisfação, da legitimidade do sistema, ou seja, das qualidades que caracterizam o sistema como adequado. Contudo, nada impede que sejam adotados instrumentos que assegurem essa vinculação.

Considerando soluções consensuais e o âmbito jurídico, pode-se pensar em formas de constituição de título executivo, como a homologação judicial, a lavratura de escritura pública, a redução a termo com a assinatura de testemunhas ou a referenda de advogado ou de órgão público competente para tanto.

É necessária a busca do instrumento mais adequada para o caso concreto. Ilustrativamente, é possível que os sujeitos do conflito sintam-se mais vinculados à solução frente à referenda do seu líder religioso ou à homologação judicial.

A utilização de ferramentas que reforcem o poder vinculativo da solução, obviamente, desencadeará um novo balanceamento ou reajuste dos custos. Por exemplo, tende-se ao aumento da segurança jurídica, por outro lado, à dilação do tempo e ao encarecimento do sistema.

\subsubsection{AVALIAÇÃO DO SISTEMA (FEEDBACK)}

Frente aos desafios fáticos que o sistema pode enfrentar, como eventuais inadequações ou readequações, é previsto o feedback.

Para que se verifique a adequação do sistema, é necessário que ele seja avaliado. Dela resultarão informações que se destinarão tanto ao exterior, como ao interior do sistema. 
As relações humanas, o que abrange as relações conflituosas, são dinâmicas. É esperado que os sistemas de solução de conflitos acompanhem essas eventuais oscilações dos conflitos que tratam para manter sua adequação. Para tanto são necessárias constante avaliação e readequação do sistema.

Ademais, existem expectativas externas ao sistema que poderão ser confirmadas, negadas ou reajustadas pelas informações adquiridas por meio do feedback. A diretoria da escola na qual foi implantado um sistema se solução de conflito ou as autoridades públicas que comungaram com a criação dos mecanismos, ilustrativamente, têm o interesse em informações que expressem o andamento das atividades e seus resultados.

O ambiente externo espera que o sistema utilize o feedback para realizar eventuais correções em seus elementos, como melhorar a adequação de seus produtos. Essa avaliação é típica dos sistemas abertos que interagem com outros sistemas.

Acrescenta-se ainda que, em cenários de conflitos repetitivos, como ocorre no caso de interesses individuais homogêneos, as informações adquiridas por meio da avaliação do sistema podem ser aproveitadas de duas formas. Primeiramente, esses dados poderão prover a eliminação de eventual inadequação, apurando a adequação do sistema para casos futuros. Além disso, as informações positivas resultantes da avaliação do sistema podem ser usadas para disseminar o conhecimento sobre o mecanismo e atrair novos sujeitos a adotar o mecanismo.

\subsection{TÉCNICAS}

Ury, Brett e Goldberg trazem, em sua obra sobre desenho de sistemas de disputa, um rol de princípios básicos. ${ }^{387} \mathrm{Da}$ forma como foram apresentados, têm natureza

\footnotetext{
${ }^{387}$ Os autores indicam os seguintes itens como princípios básicos do dispute system design: i) put the focus on interests, ii) build in "loop-backs" to negotiation, iii) provide low-cost right and power backups, iv) build in consultation before, feedback after, v) arrange procedures in a low-to-right-cost sequence, vi) provide the necessary motivation, skills, and resources. URY, William L.; BRETT, Jeanne M.; GOLDBERG, Stephen B. Getting disputes resolved: designing systems to cut the cost of conflict. $1^{a}$ Ed. São Francisco: Jossey-Bass Publishers, 1988, p. 42.
} 
diversa do conceito de princípio usado neste estudo. ${ }^{388}$ Isto é, não são tratados como normas de otimização, norteadoras, que devem ser aplicadas na maior medida possível. Os elementos dessa enumeração têm sim natureza de técnicas, meios de viabilizar que o sistema alcance seus escopos, com conteúdo específico e concreto, intrinsecamente ligado à realidade fática.

A lista de técnicas, por mais que seja considerada por seus autores como numerus claususum, será apresentada a seguir sem, contudo, compartilhar do entendimento de que se trate de rol exaustivo.

Em adição às seis técnicas básicas, das quais se ramificam outras, será também estudada a técnica dos parâmetros referências. Com esta análise, visa-se construir parte do conhecimento necessário para o posterior exame dos casos indenizatórios da segunda parte deste estudo.

Considerando que o objeto deste estudo é a análise de sistemas consensuais, foi retirado o exame do item "arrange procedures in a low-to-right-cost sequence", indicado pelos autores. Esta técnica estipula que, para evitar que o sistema não solucione o conflito, devem ser previstos mecanismos baseados em regras e/ou poder de forma suplementar ao consensual.

\subsubsection{CONSIDERAR OS INTERESSES (PUT THE FOCUS ON INTERESTS)}

A técnica de observar os interesses estabelece que o sistema deve ser composto por mecanismos, majoritariamente, voltados ao tratamento e à solução do conflito com base em interesse. Essa técnica atua de forma bifronte. Na primeira, goza os benefícios ${ }^{389}$ trazidos às partes pelos mecanismos baseados em interesse. Na segunda frente, protege às partes da perda desses benefícios, por exemplo, em decorrência do acirramento do conflito.

\footnotetext{
${ }^{388388}$ Conforme analisado no tópico PRINCÍPIOS, p. 99.

389 Conforme estudado nos tópicos INTERESSE, p. 38, e INTERESSE, REGRA E PODER: INTERRELAÇÃO, p. 45.
} 
Tendo em vista que, apesar da multiplicidade de sistemas que podem ser criados a partir do DSD, o presente estudo tem como matéria central os sistemas consensuais, a técnica de focar no interesse adquire especial importância. Por mais que, como já analisado, ${ }^{390}$ mecanismos consensuais e mecanismos baseados em interesse não sejam a mesma coisa, apresentam grande afinidade.

Partindo-se do ponto de vista de uma pessoa em conflito, não há solução melhor, mais adequada, mais satisfatória do que a que atenda integralmente os seus interesses. Contudo, o conflito pressupõe a resistência à pretensão e o sujeito desta resistência também possui os seus interesses. Cada parte tem um interesse ou um conjunto de interesses que se encontra em conflito. Ou seja, frente a toda a esfera de interesse que circunscrevem cada uma das partes, existem pontos ou áreas de interesse em conflito.

Dessa forma, um dos principais caminhos para que um mecanismo consensual baseado em interesse componha um conflito é, por meio da comunicação, destrinchando, esmiuçando os interesses de modo a expandir o conhecimento dessas esferas de interesse. Com a ampliação das informações, é possível verificar a existência de convergências nestas esferas de interesse. Esta congruência ou estas congruências, caso existam, são as possíveis soluções consensuais baseadas em interesse.

Adiciona-se a esta dinâmica, o natural escalonamento dos conflitos. Existe a tendência de que os conflitos de interesse acirrem-se para competições de direito e/ou poder. Essa situação é especialmente observada quando da demora da solução ou do início do seu tratamento adequado. Estas sucessões afastam as partes de procedimentos e soluções adequadas, já que, genericamente, há um aumento de custos.

Considerando esse cenário, é possível afirmar que a solução de um conflito que se encontre ainda em sua fase inicial evita que sejam perdidas as qualidades das vias consensuais baseadas em interesse e que sejam acrescidos os custos das competições

390 Conforme analisado no tópico INTERESSE, REGRA E PODER: BASES DA SOLUÇÃO DE CONFLITOS, p. 37. 
reguladas por normas ou poder, ${ }^{391}$ como, eventual inadequação do processamento da questão e da solução alcançada.

Isso, todavia, não deve afastar a ideia de que os meios adequados têm a qualidade da "adequação" por características próprias. Não se trata de uma busca pela via menos pior, mas sim, da mais adequada. Não se pode afastar que, eventualmente, frente à impossibilidade ou inadequação de vias consensuais, vias baseadas em regras ou, até mesmo, em poder possam vir a ser o caminho mais adequado para um determinado conflito.

Além disso, a tendência de acirramento funciona como mais um elemento informativo a ser adquirido e analisado pelas partes, para que, dessa forma, calculem suas condutas.

A técnica de observar os interesses pode ser composta por outras técnicas, técnicas secundárias, como a previsão de sistemas enxutos, múltiplas entradas e controle da retaliação.

Devido à sua própria natureza, mecanismos consensuais, especialmente os baseados em interesse, tendem a ter procedimentos enxutos, com concentração de atos, oralidade e formas brandas, ${ }^{392}$ afastando-se de estruturas altamente estratificadas e hierarquizadas. Estes sistemas têm custos menores, o que, em regra, causa reflexo direto na sua adequação. Entre outras razões, essa redução de custos é conseguida devido à sua celeridade e economia processual, que reduz os desgastes decorrentes da existência e persistência do conflito, como também os custos naturais da existência do sistema.

Dentro dos limites razoáveis de segurança jurídica e boa-fé, deve reduzir os procedimentos escritos, reclamações, repostas, réplicas e tréplicas em favor da concentração das tratativas em procedimentos orais.

Cabe ressaltar neste ponto, no qual se reflete sobre o choque entre celeridade e segurança jurídica, que a preocupação existente sobre este tema em relação aos

${ }^{391}$ Conforme URY, William L.; BRETT, Jeanne M.; GOLDBERG, Stephen B. Getting disputes resolved: designing systems to cut the cost of conflict. $1^{\mathrm{a}}$ Ed. São Francisco: Jossey-Bass Publishers, 1988, p. 42

${ }^{392}$ RACIONALIDADE DOS MECANISMOS CONSENSUAIS, p. 61. 
mecanismos adjudicatórios não pode ser trazida, em sua íntegra, aos mecanismos consensuais, nos quais há livre participação e livre composição. Adiciona-se a isso que não há supressão do contraditório, mas sim sua concentração ao longo das tratativas orais.

Por outro lado, pode ser que, para alguns casos o adequado seja desenhar potenciais subetapas na fase inicial, baseadas no consenso e no interesse. Objetiva-se, com isso, conter o conflito e evitar seu acirramento. Essa estratificação aumenta a probabilidade de êxito, pois aumenta os bloqueios para o escalonamento do conflito. Estas diferentes etapas podem se aproveitar dos benefícios dos diferentes mecanismos consensuais, ${ }^{393}$ com suas diferentes técnicas e benefícios, como a negociação, a conciliação e a mediação. Assim, há a utilização de mais de uma camada, sem que isso implique acirramento a disputas de direito ou poder.

Todavia, com a adoção desta técnica, deve-se tomar cuidado para que os passos iniciais anomalamente não sejam desencorajados e passem a ser usados pro forma. Como remédio a esta situação, deve haver o reequilíbrio do sistema, aumentando a margem de atuação dos níveis inferiores.

Por mais que, a princípio, seja recomendado um sistema enxuto que consiga conter o escalonamento do conflito, é possível que seja salutar que o sistema apresente mais de uma entrada. Isso dependerá das características e interesses dos sujeitos envolvidos, do tipo de conflito ou de questões espaciais.

É possível que o sistema perca adequação, devido à localização da sua entrada. Quanto a isso, pode se pontuar duas questões: a distância e a neutralidade do local.

Uma entrada distante, para a qual o interessado tenha custos não razoáveis de translado, pode tornar o sistema inadequado. Em conflitos que envolvam direitos individuais homogêneos, deve se verificar se existem polos de concentração de interessados e/ou reduzir o custo de translado para o interessado de forma a deixa-lo razoável ou inexistente.

${ }^{393}$ Conforme tópico RACIONALIDADE DOS MECANISMOS CONSENSUAIS, p. 61. 
Como ilustração, pode-se utilizar a experiência da Câmara de Indenização Voo 3054, que tinha como objeto conflitos provenientes de um acidente aéreo em um voo entre a cidade de Porto Alegre e São Paulo. Por mais que seja plausível que algumas vítimas estivessem fazendo conexão, é possível admitir que a grande maioria dos potenciais beneficiários encontrava-se nestes dois polos de concentração, Porto Alegre e São Paulo, ou próximos deles. Dessa forma, não só desenhou-se o sistema para que tivesse presença nestes dois polos, como também houve o custeio do translado por parte dos indenizadores. Assim, buscou-se neutralizar tanto a distância como os custos de translado para os potenciais beneficiários.

Ademais, pode ser que a parte não tenha empatia, rapport, ou sinta-se desconfortável com o indivíduo responsável por recebê-lo inicialmente no sistema, por exemplo, o conciliador ou mesmo o negociador representante da parte contrária.

Pensando em sistemas decorrentes de tragédias, em uma reflexão exemplificativa, pode ser que um parente de uma vítima sinta-se mais confortável e seguro, por motivos diversos, com a presença de um e não de outro terceiro. Prever a prerrogativa de escolha para a parte pode-se mostrar importante, eventualmente, até mesmo, essencial para o sucesso da composição.

Existe também a questão do "território do inimigo". É importante para que o sistema seja e pareça ser imparcial, que ele esteja em um local neutro. Em tese, não é interesse de nenhuma das partes que as tratativas ocorram em local sob o controle de uma ou de outra parte, por poder haver, mesmo que inconscientemente, a intimidação da outra parte.

São técnicas que, em abstrato, são contraditórias, uma vez que indicam expansão ou redução do sistema. A aplicação de uma técnica e seu grau dependerão do caso concreto. São estes ajustes finos que também colaboram com a adequação do procedimento. 
Por fim, principalmente em situações que envolvam coletividades e sistemas "multi-portas", ${ }^{394}$ é possível que indivíduos sejam retaliados por membros do próprio grupo devido à sua adoção desta ou daquela via. Normalmente, isto será verificado em casos nos quais a utilização de um determinado mecanismo enfraquece outros.

Essa situação apresenta contornos mais claros em conflitos trabalhistas, nos quais uma das possíveis formas de solução é a greve. Caso grande parte dos trabalhadores opte por tratativas consensuais e individuais para solucionar o conflito ou quaisquer outros meios que não a greve, esta, que em parte depende de quantidade, acaba esvaziada e enfraquecida. Sendo assim, é possível que haja retaliação aos trabalhadores que não aderiram à greve.

O líder dessa coletividade, caso exista, é um elemento que tende a interferir neste fenômeno da retaliação, incentivando ou desincentivando, principalmente se ele for partidário de algum mecanismo específico.

Como possível remédio, devem ser previstos procedimentos ofertando os devidos recursos informativos sobre o sistema. Estes devem ser dirigidos à coletividade $\mathrm{e}$ ao seu líder e podem ter diversas funções, por exemplo, educativa, atrativas, podendo, até mesmo esclarecer que eventual adoção de uma via não enfraquece as outras.

\subsubsection{CONSTRUÇÃO DE RETORNOS À VIAS CONSENSUAIS (BUILD IN “LOOP-BACKS” TO NEGOTIATION)}

Apesar dos benefícios dos mecanismos consensuais baseados em interesse, eles têm um inegável ponto negativo: incerteza quanto à solução do conflito. ${ }^{395}$ Este fenômeno decorre do fato de que, diferentemente da adjudicação, na qual há a imposição de um fim ao conflito, mecanismos consensuais dependem da convergência voluntária das partes, quanto ao qual não se pode ter certeza.

\footnotetext{
${ }^{394}$ Conforme tópico PLURALIDADE DE MECANISMOS DE SOLUÇÃO DE CONFLITO, p. 48. 395 Conforme analisado no tópico O PROBLEMA DA EFETIVIDADE DOS MECANISMOS CONSENSUAIS, p. 88.
} 
Frente a eventual insucesso da busca do consenso com base em interesse, é natural que haja o acirramento da questão para disputas baseadas em regras ou de poder. Contudo, ainda assim, sempre é possível que as partes tentem novamente, cheguem a um consenso e componham-se. Para tanto, cabe ao criador do sistema desenhar os retornos, atalhos que levam de volta às vias consensuais. Estes são os loop-back procedures. ${ }^{396}$

Estes procedimentos permitem que as partes ampliem seus conhecimentos sobre a situação conflituosa. Além de agregar informações, deve-se facilitar e incentivar o retorno às tratativas negociais. Não se está simplesmente criando uma nova tentativa de consenso, mas sim, passando informações aos sujeitos do conflito e, com isso, aumentando a probabilidade de sucesso, ou seja, que estas tratativas caminhem para a composição.

Por exemplo, pode-se oferecer às partes informações sobre seus direitos e possíveis resultados de uma competição baseadas em normas jurídicas. Com esta aquisição e o cálculo desses novos dados e dos novos custos, os indivíduos podem optar por voltar à mesa de negociação. Contudo, dessa vez, com mais clareza quanto a alguns aspectos como qual conduta adotar, quais interesses estão envolvidos e quais são as possíveis áreas de acordo.

Estes procedimentos podem ser meramente de aconselhamento ou vinculando as partes e solucionando parcela do conflito. Em uma perspectiva ideal, deve-se evitar passar para a próxima etapa, sem a certeza que a anterior é inadequada, sob pena de se aumentar os custos o sistema.

De qualquer forma, vinculante ou não, estes procedimento não perdem seu aspecto informativo, já que oferecem novas informações às partes, seja com uma indicação, conselho ou decisão vinculante.

Ao dirimirem ou ao indicarem possíveis soluções a questões de direito que compõe o conflito complexo ou, ainda, ao agregarem novas informações, estes procedimentos, ao não terem solucionado o conflito em sua integralidade, não impedem que as questões remanescentes sejam dirimidas por meio do consenso. Com isso,

396 Conforme URY, William L.; BRETT, Jeanne M.; GOLDBERG, Stephen B. Getting disputes resolved: designing systems to cut the cost of conflict. $1^{\text {a }}$ Ed. São Francisco: Jossey-Bass Publishers, 1988, p. 52. 
preservam-se, em alguma medida, os benefícios dos mecanismos consensuais, como a satisfação dos sujeitos, a qualidade da relação e a durabilidade do acordo. ${ }^{397}$

Propõe-se a seguinte ilustração: uma senhora alega ter direito a indenização pela morte de seu companheiro com o qual conviveu em união estável por 4 anos. Contudo, o responsável pelo pagamento da indenização entende que ela não tem legitimidade por não ser casada. Esta questão, que envolve a união estável e a legitimidade da senhora, pode ser esclarecida ou mesmo decidida com base em normas jurídicas, vinculando ou não as partes. Observa-se que este esclarecimento ou esta decisão não solucionaram o conflito, não está certo que ela receberá a indenização, nem sua quantia, nem sua forma. Todavia, informação foram ofertadas às partes, que podem prosseguir em suas tratativas.

A análise neutra de terceiro, ${ }^{398}$ a arbitragem não vinculante, ${ }^{399}$ o mini-trial, o sumary jury trial ${ }^{400}$ são alguns dos possíveis mecanismos para a aquisição de dados informativos, especialmente, as regras aplicáveis ou normas jurídicas. Estes procedimentos são meramente aconselhadores, informativos, e não vinculam as partes. Assim, não põem fim ao conflito, nem têm este objetivo.

Todavia, deve se observar que, por terem origem nas práticas norte americanas, nem todos os loop-back procedures são compatíveis ou adequados à realidade brasileira. Este é o caso do mini-trial ou sumary jury trial, uma vez que a figura do júri não está presente no nosso sistema, com exceção do âmbito penal.

397 Conforme analisado em RACIONALIDADE DOS MECANISMOS CONSENSUAIS, p. 61, e CARACTERÍSTICAS DOS MECANISMOS CONSENSUAIS, p. 69.

${ }^{398}$ Neste mecanismo, as partes apresentam o caso para um terceiro imparcial que, com base nas regras base para a avaliação do caso, profere um parecer ou uma decisão não vinculante. Com isso, acrescenta-se a parte a informação de como eventualmente um juiz pode vir a julgar e solucionar o conflito.

${ }^{399}$ Este mecanismo, também chamado de advisory arbitration, funciona como uma arbitragem, porém mais resumida e cuja decisão não vincula as partes. Exatamente por estes dois fatores é uma técnica na qual as partes conseguem levantar informações a um baixo custo. URY, William L.; BRETT, Jeanne M.; GOLDBERG, Stephen B. Getting disputes resolved: designing systems to cut the cost of conflict. $1^{\text {a }}$ Ed. São Francisco: Jossey-Bass Publishers, 1988, p. 53.

${ }^{400} \mathrm{O}$ sumary jury trial é uma adaptação do mini-trial. Nesta técnica que busca dar informações diretas sobre a reação do jurado em relação ao caso. Os advogados apresenta um resumo do caso para jurados, selecionados do quadro regular de jurados do Judiciário, que analisam o caso e apresentam seu veredicto sem que saibam que este procedimento tem natureza meramente aconselhatoria e não vinculante URY, William L.; BRETT, Jeanne M.; GOLDBERG, Stephen B. Getting disputes resolved: designing systems to cut the cost of conflict. $1^{a}$ Ed. São Francisco: Jossey-Bass Publishers, 1988, p. 54. 
O parecer de um indivíduo com legitimidade para tanto perante as duas partes, também pode ser apontado como um procedimento de retorno. Como ainda será analisado na segunda parte deste estudo, quando da análise de casos concretos, observar-se-á que o sistema desenvolvido da Câmara de Indenização do Voo 3054 utilizou-se dessa técnica ao prever a possibilidade de consulta às autoridades públicas ${ }^{401}$ envolvidas. ${ }^{402}$ Por mais que não tivesse um caráter vinculante, as respostas das consultas tendiam a dirimir dúvidas quanto à interpretação do regulamento interno, dos parâmetros referenciais ${ }^{403}$ ou outro ponto que inviabilizasse a consenso.

Por mais que o DSD vise o ajuste ideal do procedimento ao conflito, é possível que o sistema se aproveite das informações obtidas em casos semelhantes, sem que isso signifique perda da adequação. Existe um acréscimo de informação com base na experiência já adquirida pelo sistema com os casos tratados. É o que ocorre, por exemplo, com demandas repetitivas. Ressalvados casos de segredo ou confidencialidade, pode se utilizar as informações dos casos anteriores para reduzir as incertezas quanto aos possíveis resultados, oferecendo às partes padrões independentes, auxiliando em possíveis acordos ou soluções adjudicadas. A técnica dos parâmetros referências, que pode ser utilizada de forma mais ampla, não apenas como técnica de retorno, ainda será melhor analisada em tópico específico.

Observa-se que estes procedimentos de retorno e de caráter informativo, naturalmente, agregam custos ao sistema. Apesar disso, estes tentem a ser pequenos, não prejudicando significativamente a adequação do sistema.

O conflito, no entanto, frente ao insucesso inicial do consenso, pode ter se acirrado para uma competição de poder.

\footnotetext{
401 “A atuação deste órgão [Conselho Consultivo] visava ajudar os envolvidos a avaliar melhor a circunstância de seus casos e esclarecer os limites legais estabelecidos no programa com vistas a contribuir para a continuidade das negociações. O parecer emitido pelo Conselho Consultivo em resposta à dúvida não tinha teor vinculante para os envolvidos, sendo seu caráter apenas informativo. De todo modo, após sua emissão, cabia reconsideração da empresa, com posterior comunicação telefônica ou eletrônica com acompanhamento das observadoras". TARTUCE, Fernanda. Mediação extrajudicial e indenização por acidente aéreo: relato de uma experiência brasileira. In Lex Humana, v. 4, n. 1, 2012, p. 43.

${ }^{402}$ Conforme tópico VOO TAM 3054 E VOO AIR FRANCE 447, p. 177.

${ }^{403}$ Conforme tópico PARÂMETROS REFERENCIAIS, p. 155.
} 
Tendo em vista o potencial destrutivo da via e todos os seus malefícios custosos, a possibilidade de escapar para vias consensuais apresenta-se especialmente atrativa na iminência ou no meio de um embate.

A imagem do garoto grandão que quer bater no outro, franzino, que, buscando evitar o confronto e a derrota certa fala: “calma, vamos conversar!” ilustra esta situação. Obviamente, nem sempre isso ocorre de forma tão aparente, mas, o anseio de evitar uma competição de poder tende a existir, principalmente na parte que se vê como mais fraca.

Existem técnicas específicas para incentivar retornos de confrontos de poder para vias consensuais.

A técnica do colling-off period ${ }^{404}$ estipula que as partes, durante um determinado período de tempo, interromperão a disputa. Essa pausa tem como finalidade fazer não só com que os ânimos parem de se acirrar, como também que se abrandem, viabilizando, com isso, que tratativas baseadas em interesse passem a tomar o lugar da competição de poder.

Como exemplo, têm-se as normas que preveem que os trabalhadores devem esperar determinados dias antes de entrar em greve ou regras de um casal que estipula uma palavra-chave que tem o condão de interromper suas brigas por cinco minutos.

Nas hipóteses cotidianas de violência extremada, é normal que surjam terceiros para apartar o confronto, como em greves e brigas de família. As técnicas de retorno, normalmente, contam com a presença dessa figura em sua estrutura elementar.

Para que haja o melhor aproveitamento desta técnica, é necessário que este terceiro tenha os recursos técnicos adequados e que supra eventuais deficiências técnicas dos sujeitos em conflito em relação à sua atuação.

\footnotetext{
${ }^{404}$ Conforme Getting disputes resolved: designing systems to cut the cost of conflict. $1^{\text {a }}$ Ed. São Francisco: Jossey-Bass Publishers, 1988, p. 54.
} 
Para picos de agressividade nas tratativas, indicam-se os procedimentos especialmente desenvolvidos para crises (Crisis Negotiation Procedures). ${ }^{405}$ Com estas técnicas, busca-se estipular etapas procedimentais emergenciais para retardar ou evitar uma competição de poder.

Como exemplo, têm-se a hotline ou "telefone vermelho" usado pelos Estados Unidos da América (EUA) e a União das Repúblicas Socialistas Soviéticas (URSS) durante a Guerra Fria para comunicações emergenciais. Com ele, visava-se evitar que movimentos não bélicos fossem vistos como atos de guerra e desencadeassem uma guerra nuclear acidental. Recentemente, em março de 2013, esta técnica foi novamente destaque dos noticiários devido à Coréia do Norte, em sua disputa de poder com a Coréia do Sul, ter desligado a linha de comunicação de urgência que existia entre os dois países. ${ }^{406}$ Normalmente, em situações nas quais há diversas ameaças e demonstrações de poder, mal entendidos podem agravar a competição, podendo culminar até mesmo na falta de controle dos sujeitos sobre a situação.

Todavia, parece não ser razoável, por exemplo, em um mecanismo indenizatório, que um único núcleo familiar, individualmente, extrapole o sistema desenhado, buscando acirrar o conflito com uma companhia aérea para uma competição de poder.

Ao se pensar no contexto do primeiro consenso, ${ }^{407}$ com a coletividade de consumidores organizada, as autoridades e o fornecedor ou responsável, aumenta-se a probabilidade de que haja a escalada para disputas de poder, devido ao maior equilíbrio de forças.

\footnotetext{
${ }^{405}$ Getting disputes resolved: designing systems to cut the cost of conflict. $1^{\text {a }}$ Ed. São Francisco: Jossey-Bass Publishers, 1988, p. 55.

${ }^{406}$ Conforme notícia do Jornal Estado de São Paulo: "Coreia do Norte corta comunicação com Sul e vê guerra 'a qualquer momento"', disponível em: http://www.estadao.com.br/noticias/geral,coreia-do-nortecorta-comunicacao-com-sul-e-ve-guerra-a-qualquer-momento,1013872,0.htm.

${ }^{407}$ Conforme estudado no tópico OS DOIS CONSENSOS, p. 83.
} 


\subsubsection{FEEDBACK}

Ao final das tratativas, exitosas ou não, a oferta de informações ocorre por meio da técnica do feedback. É uma técnica bifronte, direcionada tanto ao passado quando ao futuro. A partir dela, têm-se uma análise voltada aos acontecimentos pretéritos, principalmente os que se deram ao longo das tratativas, e também um prognóstico da relação das partes.

Nas hipóteses nas quais o sistema não resultou na solução do conflito, esta técnica informa aos sujeitos do conflito sobre as possíveis causas desse insucesso e indica outros mecanismos existentes para o tratamento da questão.

Por sua vez, quando da composição do conflito, avalia-se a participação das partes no sistema, buscando dar ciência a elas de seus pontos fortes e fracos e o que poderia ser feito para melhor a comunicação entre elas.

Quanto à análise referente ao futuro, desenvolve-se com os sujeitos a reflexão sobre formas de melhorara relação e a comunicação, bem como evitar que novos conflitos apareçam.

Com isso, esta técnica tende a concentrar e organizar parte significativa do ideário dos conflitos construtivos.

Em ambos os casos, ou seja, dirimido ou não o conflito, o feedback também se mostra como um instrumento de avaliação do próprio sistema. Levantam-se pontos positivos e negativos do sistema, ou seja, estruturas que se mostraram adequadas ao tratamento do conflito, bem como as que se mostraram inadequadas e deveriam ou devem ser readequadas para aplicação futuro a conflitos semelhantes.

Essas inadequações podem ter algumas causas. Entre as principais, está a falha no correto diagnóstico dos aspectos da conjuntura conflituosa, o que culmina no desenho de um sistema inadequado. É possível, ainda, que o sistema fosse inicialmente adequado, contudo, tendo em vista o dinamismo do conflito, podem ter ocorrido oscilações que não 
foram acompanhadas pelo sistema, que deve passar por tantas readequações quanto as que forem necessárias para preserva a sua adequação.

Dessa forma constata-se a grande importância que esta técnica tem para o DSD, em especial, nos casos de demandas repetitivas, como nos interesses individuais homogêneos.

\subsubsection{RECURSOS: MOTIVAÇÃO, HABILIDADES}

Para o bom desenvolvimento de sistemas consensuais de solução de conflito, exige-se das partes uma postura ativa: deve ser ativa na adesão e na permanência em um mecanismo baseado na autonomia privada, de livre entrada e saída; deve ser ativa no empenho pela construção da solução consensual, para que ela exista e consiga satisfazer ao interesse seus interesses. A falta desta postura ativa pode inviabilizar o sucesso do sistema, pela não solução do conflito ou pela solução aquém das possibilidades e dos interesses dos sujeitos.

A existência ou não de uma postura ativa está diretamente ligada à motivação. Dessa forma, é necessário que o sistema tenha meios para providenciá-la, caso não exista, ou desenvolve-la, caso exista.

A motivação tem dois momentos de concentração. No primeiro, incentiva-se a adesão da parte, seja na fase de criação do sistema, seja nas tratativas que tenham como objeto a solução do conflito. No segundo, por sua vez, estimula-se a qualidade desta participação, que também será afetada pela oferta de recursos técnicos. Com isso, tem-se que não basta à adesão, esta deve ser cumulada com uma participação ativa em prol da satisfatória solução do conflito.

O sujeito ativo desta motivação, em regra, é o designer do sistema. ${ }^{408} \mathrm{O}$ designer tem função técnica, aplicando os princípios e as técnicas ao caso e criando o

${ }^{408}$ Como ainda será analisado, QUEM SÃO OS ATORES (PLAYERS)?, p. 161, os papéis podem ser cumulados em um mesmo sujeito. Dessa forma, é possível que o designer seja uma das partes, que, visando 
sistema, mas também função política e psicológica, ${ }^{409}$ reunindo esforços, superando resistências, conciliando divergência e desmotivações, por exemplo. Essa análise é válida tanto para a fase de criação, como posteriormente, tendo em vista a contínua e natural readequação do sistema.

A motivação pode ser dada de várias formas a depender dos atores do conflito. ${ }^{410}$ A principal delas é a informação dos custos, lembrando às partes da adequação do sistema.

Além de ser, o sistema tem que parecer atrativo. Informações sobre a qualidade do sistema devem atingir os sujeitos de forma a convencê-los, como por meio da divulgação dos primeiros sucessos do mecanismo.

Mesmo que os sujeitos estejam motivados, deve-se ter consciência que a desmotivação é uma força potencial e de constante presença. É possível que para algumas partes as dificuldades pareçam maiores quando mais próximas. Durante a vivência do processo de criação ou mesmo ao longo da busca pela composição, as tratativas podem parecer tão árduas, que um dos sujeitos pode entender ser melhor "partir para a guerra", como se a solução fosse se dar de forma menos custosa.

A discrepância de custos é grande entre a guerra e as vias consensuais, mas as emoções e a proximidade ${ }^{411}$ com os custos podem fazer com que o indivíduo não os consiga calcular corretamente.

Constata-se, dessa forma, que a técnica da motivação não é pontual. Sua presença deve ser constante no sistema.

\footnotetext{
um processamento e uma solução adequados, proponha a aplicação do DSD ao caso. Nesta hipótese, por exemplo, caberá este sujeito, que é tanto parte como designer, prover a motivação.

${ }^{409}$ Getting disputes resolved: designing systems to cut the cost of conflict. $1^{\mathrm{a}}$ Ed. São Francisco: Jossey-Bass Publishers, 1988, p. 65.

${ }^{410}$ QUEM SÃO OS ATORES (PLAYERS)?, p. 161.

${ }^{411}$ Busca-se diferenciar os custos próximos e concretos, que estão sendo suportados ao longo da criação de um sistema ou do tratamento do conflito, dos custos remotos e abstratos, que poderiam ser suportados na hipótese de aplicação de outro mecanismo de solução de conflito.
} 
As habilidades, por sua vez, são os recursos técnicos, de cunho intelectual e buscam qualificar a participação das partes. Não se limitam a estes sujeitos, atingem também todos os indivíduos que façam parte do insumo humano ${ }^{412}$ do sistema.

Deve haver a adequada capacitação de todos. O que não significa que será igual para todos. Ela será condizente com a função que cada indivíduo exercerá no sistema.

Ela pode ser alcançada por meio de treinamentos, leitura, discussões, simulações. Esta última dá experiência às partes e aos outros sujeitos do sistema e faz com que eles conheçam quais são as posturas e condutas esperadas deles durante o procedimento.

Além disso, cabe mencionar que, paralelamente a isso, o sistema deve prever programas de seleção, avaliação e reciclagem dos membros que comporão a estrutura humana do sistema, como mediadores e assistentes.

Este treinamento é essencial, já que, de alguma forma, estes sujeitos representavam o sistema para as partes. Os observadores, assistentes jurídicos e até mesmo os indivíduos responsáveis por recepcionar os sujeitos em conflito e providenciar seu translado. Não se trata de um simples atendimento ao público, já que se trabalha em uma situação de conflito e de grande carga emocional, o que pode promover rápido e intenso agravamento de questões.

\subsubsection{PARÂMETROS REFERENCIAIS}

Os sistemas que têm como objetivo o tratamento adequado de conflitos repetitivos $^{413}$ enfrentam desafios próprios, que, em alguns casos, decorrem do choque de forças antagônicas.

${ }^{412}$ Como analisado em INSUMOS (INPUTS), p. 136.

413 Aplicam-se os termos "repetitivos" e "semelhantes" de forma sinônima. Busca-se abranger questões cujas causas de pedir, pedido e, eventualmente, sujeitos são semelhantes. Quanto a este último elemento, especificamente em relação à repetição dos sujeitos, ilustrativamente, pode-se pensar em uma relação 
Como tratar demandas semelhantes de forma massificada, sem que isso implique afastar a individualização e a criação de respostas próprias para as peculiaridades de cada caso? Por outro lado, como individualizar o processamento e a solução destas questões repetitivas, sem perder as vantagens de custo e a coerência sistêmica que um tratamento homogêneo pode propiciar ou potencializar?

Deve-se ter como premissa que, a cada processo, as partes e o sistema adquirem experiência e outras espécies de dados pertencentes ao gênero "informação".

Após o processamento de um ou alguns conflitos semelhantes que sejam homogêneos e tenham como origem comum um determinado acidente de consumo, podese chegar à percepção, ilustrativamente, de que existe um potencial receio dos beneficiários de negociar diretamente com a empresa responsável pelo pagamento da indenização. Tendo em vista que os receios também são elementos integrantes dos interesses dos sujeitos, têm-se, dessa forma, entre os interesses dos beneficiários, o de não entrar em tratativas diretas com indenizador.

Esse, ainda exemplificativamente, pode ter como fundamento o medo de ser ludibriado ${ }^{414}$ pela outra parte, uma vez que são leigos, inexperientes neste tipo de situação, enquanto do outro lado da mesa há uma grande empresa, com seus advogados, especialistas em negociação, com larga experiência. Apesar de essa situação ser uma ilustração, é factível que conjunturas e pensamentos como estes possam existir.

A inexperiência faz com que, neste exemplo, os beneficiários não saibam quais são as possibilidades, quais caminhos seguir, quais condutas adotar, quais são os elementos de uma boa solução, quais são os acordos possíveis, se se deve barganhar e oferecer uma contraproposta sobre o que foi ofertado e, com isso, ser estabelecida uma dinâmica semelhante a um leilão quanto ao valor de uma indenização que pode ser referente ao falecimento do seu próprio filho. Todas essas questões estão cumuladas ao receio inicial de ser enganado.

continuada, por exemplo, um contrato relacional entre empresas, o qual dê origem a inevitáveis conflitos ou ainda em um responsável por indenizar um grande número de pessoas.

${ }^{414}$ Cabe destacar que, uma vez configuradas, condutas anômalas ou patológicas podem viciar o negócio jurídico, podendo culminar na sua inexistência, nulidade relativa ou absoluta. CONSENSO: NATUREZA JURÍDICA, p. 64. 
Adquirindo essas informações, é possível que se pense em um mecanismo que busque sanar ou mitigar essas questões, potencializando tratativas e soluções mais adequadas. São desafios que devem ser considerados e respondidos ao longo da criação do sistema.

Contudo, esta aquisição de informação ao longo do procedimento tem seu custo. Entre outras espécies de custo, cabe destacar os de transação e de aprendizagem.

Uma característica forte presentes no tratamento de conflitos repetitivos é a possibilidade de uso dessas informações adquiridas de casos pretéritos. Isto, no entanto, gera o conflito entre a individualização e a massificação.

Caso, visando preservar a máxima individualização, fosse necessário afastar todas essas informações colhidas de casos anteriores, haveria a repetição dos custos referentes à aquisição destes dados em todos os processos. Destaca-se, todavia, que não se trata de uma simples repetição de custos, mas sim de uma repetição plenamente evitável, já que o sistema em si já suportou estes custos e já tem as informações. Esta adição de custos, qualificados por sua prescindibilidade, interfere direta e negativamente na adequação do sistema.

É possível, em alguma medida, utilizar essas informações sem que isso resulte na quebra da individualização e, consequentemente, da adequação do mecanismo. A aplicação destes dados, que já tiveram seus custos acrescidos ao sistema em momento anterior, pode ser um instrumento de redução global de custos do presente sistema ou de futuros, como será analisado quando da relação dos dois casos de acidentes aéreos objetos deste estudo.

Desse raciocínio de aproveitamento das informações adquiridas do processamento de conflitos semelhantes, juntamente com a necessidade de informar as partes, origina-se a técnica dos parâmetros referenciais. ${ }^{415}$

415 "When a new claim is filed, the designers identity similar claims in the data base and use the information about the outcomes of previously resolved cases to determine the range within which the new case is likely to be resolved. This information reduces uncertainty about the likely outcome of the case and provides an independent standard that can help the lawyers settle the case". Getting disputes resolved: designing systems to cut the cost of conflict. $1^{\text {a }}$ Ed. São Francisco: Jossey-Bass Publishers, 1988, p. 53. 
Esta técnica oferece aos sujeitos, a baixo custo, informação referencial sobre a conjuntura do conflito, com a qual elas poderão comparar os elementos presentes nas tratativas. Com isso poderão entender as possibilidades e o que seria uma boa escolha ou uma boa conduta, capacitando as a realizar suas tomadas de decisão, “jogadas” de forma fundamentada e potencialmente mais próximas de atender aos seus interesses. Assim, os parâmetros referenciais podem ser entendidos como um conjunto de informações que serão usadas pelas partes como pedra de toque com as quais compararão suas pretensões e condutas. $^{416}$

Essas informações referenciais podem ser tanto meio, como critérios de cálculo, como fim, "parentes colaterais não coabitantes devem receber o valor pecuniário de " $x "$ referente aos seus danos morais".

Esta técnica tem especial importância para este estudo, pois está presente nos dois casos que serão estudados. ${ }^{417}$

Por meio dessa técnica, as partes conseguem ter um melhor conhecimento da situação, das possibilidades e probabilidades. Considerando os parâmetros referenciais, a parte tem condições de avaliar seus próprios interesses e perceber que eles estão além ou aquém do espectro de soluções possíveis. Com isso, pode readequar seus interesses e alcançar uma solução mais adequada.

A técnica dos parâmetros referenciais, ao oferecer informação e possibilitar a eventual readequação dos interesses, maximiza a possibilidade das partes alcançarem um acordo condizente com seus interesse, aumentando a satisfação. Além disso, esta técnica aumenta a percepção de justiça dos sujeitos em relação ao mecanismo, como também sua celeridade.

\footnotetext{
${ }^{416}$ Com raciocínio semelhante, mas não idêntico, McGovern indica o pagamento por meio da técnica de tabela (grid): "More popular in claims resolution facilities is a grid for payment composed of a small number of variables, usually three or five. Once eligible, a claimant is placed on a grid depending upon the evidence on the limited number of axes and awarded the designed amount. In the event that payment is more fin-tune, a larger number of variables-typically more than five but less than twenty - can be considered and applied by the use of an algorithm or formula. Sometimes data is collected from cases resolved in the litigation system and regression analysis reveals that the normal outcomes can be explained by the interaction of a small number of variables that can be weighted in an algorithm that then approximates the historic calculation of damages". MCGOVERN, Francis E. The what and why of claims resolution facilities. In Stanford Law Review, Vol. 57, April 2005, p. 1372.

${ }^{417}$ VOO TAM 3054 E VOO AIR FRANCE 447, p. 177.
} 
Esta é resultado da aproximação dos pontos de partidas dos sujeitos proporcionada pelos parâmetros referenciais. Como o procedimento inicia-se com as partes em patamares próximos e com uma moldura referencial pré-estabelecida, existe a tendência que o sistema atinja seu escopo de forma mais rápida.

Além disso, há também o incremento na percepção das partes quanto à justiça do sistema. Isso em decorrência não só da isonomia no tratamento dos indivíduos, que têm como base o mesmo parâmetro, como também da ciência da forma de funcionamento da técnica dos parâmetros referências. Ou seja, os indivíduos sabem que não existem privilégios, nem discriminações cujos fatores de discrímen sejam ilegítimos, inadequados ou diversos dos apresentados pelos parâmetros referenciais. Assim, por exemplo, todos os consumidores sabem que receberam suas indenizações com base nos mesmos parâmetros.

Como sistema, os mecanismos desenhados a partir dos preceitos do DSD, devem manter sua coerência sistêmica, o que abrange seus produtos, ou seja, as soluções dos conflitos. A existência de parâmetros, mesmo que só apontem informações de meio, como critérios de processamento e de solução, aumentam a probabilidade de que o sistema consiga atender a essa característica.

Esta coerência sistema e a isonomia de tratamento, potencializadas por esta técnica, aumenta a segurança das partes em relação ao sistema e, assim, torna-o mais atrativo.

Os parâmetros referenciais permitem, com isso, que haja, por exemplo, a indenização de valores diferentes a indivíduos diferentes, mas com base em critérios iguais.

A individualização não é afastada por essa técnica, pois os parâmetros estabelecem informações referenciais, que norteiam ou contextualizam as partes, mas não as vinculam, necessariamente. ${ }^{418}$

\footnotetext{
${ }^{418}$ Nada impede que o sistema preveja os parâmetros referências como vinculantes ou como valores mínimos ou máximos para as tratativas. É possível, por exemplo, que em conflitos de consumo, autoridades públicas acordem com o responsável pelas indenizações que os parâmetros servirão como "piso" nas tratativas deste com os consumidores. Isto, conduto, pode fazer com que o sistema ou a aplicação da técnica deixe de ser interessante para o indenizador.
} 
Ao se aplicar essa técnica, é necessária especial atenção para um dos seus aspectos: a legitimidade. Ela decorre principalmente da origem das informações, que devem estar em consonância com valores tidos como importantes e corretos para os sujeitos do conflito. A legitimidade é passível de gradação. Dessa forma, é possível pensar em parâmetros mais ou menos legítimos.

Como exemplo, pode-se pegar o caso dos sistemas indenizatórios, que ainda serão estudados. ${ }^{419}$ Ambos os programas utilizam a técnica do parâmetro referenciais que têm como base informações extraídas da jurisprudência dos tribunais superiores, especificamente, do Superior Tribunal de Justiça.

\subsection{APLICAÇÃO DO DSD}

No momento da criação do sistema, o designer deve analisar o conflito, seus sujeitos e seu ambiente à procura das suas características, peculiaridades e complexidades. Após a colheita destas informações deve encontrar as respostas processuais mais adequadas para cada aspecto do conflito. Deverá organizar estes produtos alcançados de forma a um sistema capaz de tratar e solucionar o conflito com base no qual foi desenhado.

Quanto aos sujeitos, além dos polos do conflito, é necessária a análise dos espectadores interessados. Estes não são simples terceiros, pois apresentam determinada incumbência dentro do sistema, como legitimar, fiscalizar ou prover recursos financeiros ou técnicos.

Paralelamente, parte das informações necessárias para o desenho de um sistema personalizado pode ser obtida com a análise dos mecanismos de solução de conflito existentes. Devem ser verificados quais são ou não usados e as razões para tanto. Com isso, passa-se a se ter, em concreto, maior conhecimento do que venha ser adequado ou inadequado para o tratamento da situação conflituosa.

${ }^{419}$ VOO TAM 3054 E VOO AIR FRANCE 447, p. 177. 
Nos próximos tópicos, buscar-se-á desenvolver melhor estes dois aspectos da aplicação do DSD por concentrarem grande parte da atividade de criação.

\subsubsection{QUEM SÃO OS ATORES (PLAYERS)?}

O diagnóstico da conjuntura conflituosa, com o levantamento de informações necessárias para a criação de um sistema personalizado de tratamento de um determinado conflito nos moldes estipulados pelo método do DSD, abrange a identificação e a análise dos seus atores. A correta identificação e análise deste é imprescindível para a adequação e sucesso do sistema.

Quando se pensa em conflito, a estrutura elementar que vem a cabeça é a de dois atores principais, as partes: de forma simplificada, dois indivíduos em posições antagônicas. Estes sujeitos, contudo, não são os únicos relevantes para o sistema.

Os atores são os sujeitos, cujos interesses e características devem ser considerados para o desenho do sistema. Emprega-se o termo "atores", porque eles não só têm interesses relevantes no tratamento da questão, como também exercem determinados papéis no conflito ou os exercerão no mecanismo criado.

Estes papéis são atribuídos por previsão legal, ${ }^{420}$ consenso ou como resultante de situações fáticas. É por meio dessas atribuições e de elementos fáticos que é possível a análise da existência ou não do interesse relevante do sujeito.

Por exemplo, o conselho acadêmico de uma escola que tenha criado um sistema de solução de conflitos exclusivamente entre os alunos, por mais que não seja parte, apresenta interesse relevante no mecanismo e exerce alguns papéis, como o de prover os recursos financeiros e técnicos para o sistema, além de fiscalizar e legitimar.

${ }^{420}$ Como exemplo, destaca-se a previsão do artigo $4^{\circ}$, inciso V do Código de Defesa do Consumidor: "Art. $4^{\circ}$ A Política Nacional das Relações de Consumo tem por objetivo o atendimento das necessidades dos consumidores, o respeito à sua dignidade, saúde e segurança, a proteção de seus interesses econômicos, a melhoria da sua qualidade de vida, bem como a transparência e harmonia das relações de consumo, atendidos os seguintes princípios: [...] V - incentivo à criação pelos fornecedores de meios eficientes de controle de qualidade e segurança de produtos e serviços, assim como de mecanismos alternativos de solução de conflitos de consumo". 
Os atores elementares, que devem ser, imprescindivelmente, identificados e analisados quando do desenho de um sistema, são as partes, o provedor de recursos financeiros e o de recursos técnicos. Entre os que são prescindíveis, em uma enumeração não exaustiva e considerando os sistemas indenizatórios que serão objeto de estudo, é relevante apontar o fiscal e o legitimador do sistema.

As partes são assim consideradas elementares, pois são a razão de existir do sistema, sobre cujos interesses e características o desenho e sua busca de adequação serão pautados. Por sua vez, os provedores de recursos financeiros e técnicos são de primeira importância, uma vez que viabilizam o sistema. ${ }^{421}$

Existe a possibilidade que a atribuição de papéis seja cumulativa ou concorrente. Desse modo, um mesmo ator pode cumular papéis, assim como sujeitos diferentes podem ter a mesma atribuição.

Na Câmara de Indenização Voo 3054 e no Programa de Indenização Voo 447, as empresas aéreas e suas respectivas seguradoras, além de parte, tinham o papel de financiadoras do sistema. ${ }^{422}$

Tendo em vista as previsões do Código de Defesa do Consumidor, ${ }^{423}$ é natural que estes sujeitos arcassem não só com as indenizações, como também com os custos financeiros do mecanismo criado para pagá-las. Todavia, esta cumulação de funções tende a criar nos consumidores uma desconfiança quanto à imparcialidade do sistema em um contexto em que a relação de consumo já não é equânime.

\footnotetext{
${ }^{421}$ Por mais que possa parecer ser um contrassenso considerar os interesses e características do provedor de recursos financeiros, quando este papel não está atribuído a uma das partes, já que ele não é figura nos polos do conflito, sua existência é imprescindível para viabilizar o sistema. Contudo, normalmente, as partes e o provedor de recursos costumam comungar o interesse pelo tratamento adequado do conflito. Pode-se pensar, por exemplo, no conselho da escola e as partes como sendo os alunos ou ainda o empregador que custeia o sistema para dirimir os conflitos entre seus empregados. Atender. Apesar dessa reflexão, deve-se lembrar que, principalmente quando da aplicação de sistemas indenizatórios de danos provenientes de relação de consumo, o papel de provedor de recursos financeiros tenderá a recair sobre uma das partes, em especial da parte responsável pela indenização.

${ }^{422} \mathrm{O}$ artigo $7^{\circ}$ do regimento interno do Programa de Indenização Voo 447 previa: "Compete à Air France e à AXA observar todos os princípios e regras revistas neste regimento, responsabilizando-se pela implementação efetiva do PI 447 e também: I pelo fornecimento das instalações e equipe adequadas, arcando com todos os custos necessários, inclusive o de contratação de pessoal". Regimento Interno - Programa de Indenização Voo 447, p. 6.

${ }^{423}$ Conforme analisado em RESPONSABILIDADE CIVIL E INTERESSES INDIVIDUAIS HOMOGÊNEOS DOS CONSUMIDORES, p. 23.
} 
A participação das autoridades públicas teve o condão de afastar ou minorar essa desconfiança. Para tanto, atuaram como equalizadores da relação e do sistema, fiscalizando e legitimando-o. ${ }^{424}$ Com isso, as autoridades aumentaram a segurança do mecanismo, influenciando na queda de seus custos.

Cabe ponderar, no entanto, que a existência de autoridades públicas entre os atores pode ter como consequência o aumento de uma ou outra espécie de custos, como os de transação, mas, quando da análise sistêmica dos custos, constata-se uma tendência de redução.

A atribuição concorrente pode ser observada, por exemplo, nas hipóteses em que as duas partes financiam o sistema ou quando mais de uma autoridade pública tem a função de fiscalizar e legitimar.

Por mais que as partes estejam entre os atores centrais, a depender da situação, é possível que o seu apoio para a criação do sistema torne-se secundário em comparação ao apoio de outros atores. ${ }^{425}$ Normalmente, este fenômeno será observado quando da existência de dois fatores: fraqueza das partes e força de outros sujeitos.

Essa fraqueza, especialmente nas hipóteses de interesses individuais homogêneos, tende a decorrer da desorganização dos consumidores, não conseguindo concentrar sua força e interesses.

A força dos outros atores, por outro lado, costuma decorrer exatamente da diluição dos interesses das partes, como ocorre, por exemplo, com as autoridades publicas

${ }^{424} \mathrm{O}$ artigo $8^{\circ}$ do regimento interno do Programa de Indenização Voo 447 previa: “Aos órgãos que integram o Sistema Nacional de Defesa do Consumidor (art. $6^{\circ}$ supra) compete: I - monitorar o andamento e zelar pelo constante aprimoramento do PI 447; II - supervisionar e orientar os trabalhos da Divisão de Assistência (art. $9^{\circ}$.); III - promover o funcionamento dos mecanismos alternativos de resolução de controvérsias previstos neste Regimento (arts. $9^{\circ}$, II e IV e art. 10); IV - garantir a estrita observância do presente Regimento, dos princípios e direitos fundamentais, previstos na Constituição Federal de 1988, na Lei nº 8.078, de 11 de setembro de 1990, nos artigos 944 e seguintes do Código Civil de 2002". Regimento Interno - Programa de Indenização Voo 447, p. 6.

${ }^{425}$ Conforme URY, William L.; BRETT, Jeanne M.; GOLDBERG, Stephen B. Getting disputes resolved: designing systems to cut the cost of conflict. $1^{\mathrm{a}}$ Ed. São Francisco: Jossey-Bass Publishers, 1988, p. 71. 
que têm legitimidade para substituir os consumidores e tutelar coletivamente seus interesses. $^{426}$

$\mathrm{O}$ apoio dos consumidores pode vir em um segundo momento, aderindo ao sistema já criado, após o consenso referente à criação e adoção do mecanismo ter sido firmado pelas autoridades públicas, por exemplo.

Está não é a hipótese ideal, já que se tende a perder o sentimento de autoria e autodeterminação quanto ao desenho do sistema, por mais que esses aspectos sejam preservados quanto ao tratamento individualizado do conflito. ${ }^{427}$

Não é necessário que a identificação e a análise dos atores ocorram em concreto para que o sistema comece ser desenhado. Nem sempre, no momento inicial, será possível determinar concretamente todos os sujeitos legítimos para atuar como parte no sistema, principalmente nas hipóteses de conflitos que envolvam interesses individuais homogêneos.

Mesmo para acidentes aéreos, por exemplo, nos quais, em regra existe uma lista de passageiros e tripulantes, determinando-se as vítimas que estavam a bordo da aeronave, ainda assim, não é possível determinar todos os legitimados a participar do sistema como partes, já que os custos tendem a tornar impraticável a definição de todos os beneficiários decorrentes dessas vítimas. ${ }^{428}$

Não há relevância se a identificação e análise se dão em concreto ou em abstrato, contanto que o designer tenha condições se alcançar as informações sobre as características e interesses destes sujeitos, mesmo que em abstrato, de modo a conseguir desenhar adequadamente o sistema.

Ilustrativamente, por mais que não tenha sido possível a determinação em concreto de todos os possíveis legitimados ativos de uma demanda indenizatória decorrente de um acidente aéreo, é possível que sejam feitas as seguintes suposições: i) o

${ }^{426}$ INTERESSES Conforme tópico INTERESSES INDIVIDUAIS HOMOGÊNEOS, p. 19.

${ }^{427}$ Quanto a essa reflexão, ver OS DOIS CONSENSOS, p. 83, e a tutela coletiva e individual.

${ }^{428}$ Esta questão foi desenvolvida quando da análise dos limites subjetivos do sistema, no tópico LIMITES, p. 128. 
titular do direito e do interesse de ser indenizado é uma vítimas direta do acidente ou é beneficiário de uma dessas vítimas diretas, provavelmente com relação de parentesco ou vínculo afetivo; ii) devido à natural magnitude dos acidentes aéreos, é provável a existência de vítimas fatais e ou lesões físicas e psíquicas graves, devendo existir forte carga emocional; iii) a princípio, ${ }^{429}$ os legitimados ativos serão pessoas físicas; iv) é provável que entre as vítimas ou entre os beneficiários dessas vítimas existam menores, o que acarreta especial atenção quanto a aplicação de mecanismos consensuais; ${ }^{430}$ v) é possível que haja urgência no recebimento do valor a ser pago pelo falecimento, por exemplo, do arrimo da família. Estas suposições seriam algumas das questões que o designer teria que enfrentar no desenho do sistema.

Cabe destacar e refletir sobre uma peculiaridade a se enfrentar nos conflitos de interesses individuais homogêneos quanto ao ator "coletividade". A princípio, considerando demandas indenizatórias, ela se apresentará como parte, mais especificamente, como legitimado ativo. Contudo, dependendo do ângulo e do momento em que observa este ator, ele poderá mostrar facetas diferentes.

Em alguns momentos será a coletividade considerada dentro da sua natureza de grupo. Especialmente quando de condutas informativas ou dinâmicas políticas, por exemplo, quando da proposta de aplicação do DSD e quando do ingresso das autoridades públicas.

Em outros, esta coletividade estará concentrada na figura de seus representantes, como o presidente ou o porta-voz de uma associação de vítimas, familiares e outros beneficiários. Como ocorrerá, por exemplo, para a formalização do primeiro

\footnotetext{
${ }^{429}$ Excecionalmente, é possível que o acidente tenha atingido interesse de pessoa jurídica, por exemplo, de empresa cuja cúpula administrativa estava a bordo e veio óbito com o acidente.

${ }^{430}$ Deve-se verificar a necessidade de formalidades legais, como homologação judicial, para que o acordo tenha valor em relação aos interesses do menor. O artigo 51do Regimento Interno do Programa de Indenização Voo 447, traz as seguintes disposições para casos que envolvam incapazes: "§ $1^{\circ}$. Nos casos previstos em lei, mormente aqueles envolvendo menores Beneficiários, o acordo será submetido à homologação judicial e o pagamento será feito, por meio de depósito bancário, em até 20 dias da data publicação da homologação, contra a qual não couber qualquer recurso pelas partes e/ou pelo Ministério Público. [...] $3^{\circ}$. Quando houver interesse de menores, o Ministério Público, sem prejuízo da futura homologação judicial, será cientificado, nos termos do Anexo 05, para que se pronuncie sobre a divisão do valor pactuado, na forma sugerida pelos Beneficiários. [...]§ $6^{\circ}$. Nos casos em que exista interesse de menor envolvido, a homologação do acordo contará com a participação de todos os Beneficiários que estejam sendo indenizados por danos materiais". Regimento Interno - Programa de Indenização Voo 447, p. 21.
} 
consenso, ${ }^{431}$ ou quanto da atividade construtiva do sistema. Não é viável que todos os indivíduos da coletividade assinem o termo de compromisso de criação do sistema, nem que todos participem diretamente da definição dos mecanismos, técnicas, procedimentos que o sistema terá.

Por fim, quando das tratativas de cada conflito individualmente considerado, estar-se-á trabalhando com uma unidade desta coletividade, um indivíduo ou um núcleo de indivíduos com estreita relação, eventualmente, por serem beneficiários de uma determinada vítima.

Por fim, cabe analisar o provedor de recursos técnicos. A princípio, está é uma atribuição do designer. Ele, além de criar o sistema de solução de conflito com a participação das partes, tende a acompanhar as atividades do sistema, bem como seu desfecho, quando do feedback, para avalia-lo e, eventualmente, readequá-lo. ${ }^{432}$

Os recursos técnicos devem conter os conhecimentos referentes ao ideário do DSD, seus princípios e técnicas. Além disso, há aplicação de teorias e técnicas jurídicas, ${ }^{433}$ buscando desenvolver aspectos do devido processo legal que sejam compatíveis com o sistema. ${ }^{434}$

Dessa forma, o designer atua tanto como um consultor, como um mediador, assisting the parties in designing their own system, one that works best for them". 435

431 O "primeiro consenso" está em contraposição ao eventual consenso alcançado como resultado das tratativas, o processamento do conflito pelo mecanismo, com o qual há a composição do conflito. O primeiro consenso refere-se à adoção e criação do sistema. Os dois consensos serão analisados em: OS DOIS CONSENSOS, p. 83.

${ }^{432}$ Conforme URY, William L.; BRETT, Jeanne M.; GOLDBERG, Stephen B. Getting disputes resolved: designing systems to cut the cost of conflict. $1^{a}$ Ed. São Francisco: Jossey-Bass Publishers, 1988, p. 77.

433 "This is not to suggest that only lawyers may facilitate or design such new processes, but that lawyers may be particularly well suited to marry legal formalities and requirements to more flexible, fair, and participatory modes of political and legal action. Whether lawyers hinder such processes by focusing too exclusively on legalistic or 'due process' concerns or whether lawyers will learn to utilize their craft to develop flexible and effective new processes, to produce different kinds of outcomes remains to be seen". MEADOW, Carrie Menkel. Mothers and Fathers of Invention: The Intellectual Founders of ADR. Ohio: Ohio State Journal on Dispute Resolution, 2000, p. 30.

${ }^{434}$ Conforme analisado no tópico RACIONALIDADE DOS MECANISMOS CONSENSUAIS, p. 61, nem todos os aspectos do devido processo legal aplicáveis à adjudicação estatal são compatíveis com vias consensuais de solução de conflito.

${ }^{435}$ COSTANTINO, Cathy A.; MERCHANT, Christina Sickles. Designing conflict management systems. $1^{\mathrm{a}}$ Ed. São Francisco: Jossey-Bass, 1996, p. IX. 


\subsubsection{DIAGNÓSTICOS DOS SISTEMAS EXISTENTES}

O estudo dos mecanismos existentes e dos costumeiramente empregados pelas partes para solucionar seus conflitos é uma etapa da atividade de desenho do sistema de solução de conflitos. ${ }^{436}$

Esta análise tem como objetivo o levantamento de informações sobre os mecanismos de solução de conflitos disponíveis às partes, especificamente das características que os tornam adequados ou inadequados para elas e seus conflitos. ${ }^{437}$

Ao fim desta análise, entre outras informações, terá sido construída uma lista de características a serem evitadas ou não pelo designer. Levanta-se também qual é a visão das partes quanto ao que seria um mecanismo ideal. Com isso, adquire-se informações sobre os seus interesses.

Mais uma vez, assim como na técnica dos parâmetros referenciais, utilizam-se experiências pretéritas como meio de obter informações a um baixo custo.

Este estudo sobre a forma de controle dos conflitos pode oferecer, se realizado de forma sistêmica, a oportunidade única para que as partes aprendam informações críticas e globais sobre suas relações, operações, escolhas, conflitos, população ${ }^{438}$ e área afetada, por exemplo. Adquire-se dados referentes à dinâmica dos conflitos, como surgem, quais são os efeitos sobre as pessoas e relações, como são tratados, por que são tratados assim, entre outras informações desse gênero. ${ }^{439}$

Desse modo, o DSD pode ofertar reflexamente este benefício. Isto é, disponibiliza não apenas um sistema para a solução de um determinado conflito, mas

\footnotetext{
${ }^{436}$ Conforme URY, William L.; BRETT, Jeanne M.; GOLDBERG, Stephen B. Getting disputes resolved: designing systems to cut the cost of conflict. $1^{\text {a }}$ Ed. São Francisco: Jossey-Bass Publishers, 1988, p. 20.

${ }^{437}$ Conforme URY, William L.; BRETT, Jeanne M.; GOLDBERG, Stephen B. Getting disputes resolved: designing systems to cut the cost of conflict. $1^{\text {a }}$ Ed. São Francisco: Jossey-Bass Publishers, 1988, p. Xv.

438 Considera-se, quanto ao item populações, organizações, sejam públicas, sejam privadas, como departamentos governamentais, escolas e empresas.

${ }^{439}$ COSTANTINO, Cathy A.; MERCHANT, Christina Sickles. Designing conflict management systems. $1^{\mathrm{a}}$ Ed. São Francisco: Jossey-Bass, 1996, p. 18.
} 
também, permiti que os sujeito, como organizações ou litigantes contumazes, tenham acesso a informações sobre o panorama em que se encontram (big picture). ${ }^{440} 441$

Partindo para uma análise mais pormenorizada, conforme entendimento de Ury, Brett e Goldberg, ${ }^{442}$ o diagnóstico do sistema de solução de conflito existente se dá por meio das respostas às seguintes perguntas: “o que?", “como?” e “por qual razão?”.

Com a primeira, busca-se verificar qual o tipo de conflito que será trabalhado no sistema de solução de conflito. Além disso, são levantadas questões quantitativas, como quantos conflitos, quantas partes, quão frequentes são estes conflitos.

Dessa forma, por exemplo, se o conflito tiver, entre as suas características, forte carga emocional, é adequado que existam procedimentos para que estas emoções sejam ventiladas de forma benéfica ao processamento e à solução da questão. Por outro lado, conflitos que envolvam puramente questões legais ou técnicas, entre grandes empresas multinacionais do ramo de tecnologia, é possível que mecanismos de baixo custos baseados na definição de quem está certo mostrem-se os mais adequados.

A segunda pergunta, “como?", deve ser decomposta em: como os conflitos são solucionados? Quais são os mecanismos adotados? Quais são os custos e os benefícios da utilização desses mecanismos? Com essa pergunta busca-se destrinchar e diagnosticar o sistema aplicado normalmente pelas partes para solucionar seus conflitos.

Por meio da última pergunta, "por que?", tem-se como finalidade descobrir o que motiva as partes a adotar este e não aquele caminho para solucionar seus conflitos. $\mathrm{O}$ que as partes pretendem com a utilização desse mecanismo? Quais são os obstáculos para a utilização de vias que tenham como base a conciliação de interesses? Qual é a capacitação das partes para usar os diferentes meios? É a capacitação um elemento que limita ou incentiva a escolha? Além dos recursos técnicos, qual é a disponibilidade de recursos financeiros?

\footnotetext{
${ }^{440}$ Conforme COSTANTINO, Cathy A.; MERCHANT, Christina Sickles. Designing conflict management systems. $1^{\text {a }}$ Ed. São Francisco: Jossey-Bass, 1996, p. XIV.

${ }^{441}$ Ideias semelhantes de aprendizado por meio da superação do conflito podem ser encontradas nos estudos sobre Mary Parker Follet, analisadas em MECANISMOS CONSENSUAIS, p. 59.

442 Conforme URY, William L.; BRETT, Jeanne M.; GOLDBERG, Stephen B. Getting disputes resolved: designing systems to cut the cost of conflict. $1^{\mathrm{a}}$ Ed. São Francisco: Jossey-Bass Publishers, 1988, p. 20.
} 
Levanta-se, paralelamente, informações sobre quais são e como são os meios existentes mas não adotados.

A partir do estudo qualitativo dessa adoção, juntamente com sua análise de custos e benefícios, o desenhista criativamente tentará buscar melhorias para os custos e maximizar os benefícios, assim como aproveitará destas experiências e informações na criação do novo sistema de solução de conflito.

Porque as partes resolvem seus problemas em competições de direito ou de força e não por meio de mecanismos consensuais baseados em interesse? As partes tem ciência da existência de diferentes mecanismos? As partes têm liberdade nesta escolha? Seria pela indisponibilidade de vias consensuais ou seria por falta de motivação para usálos, por falta de recursos técnicos ou financeiros ou por algum obstáculo dentro da relação ou do largo contexto socioeconômico que se encontram. ${ }^{443}$

Esta última pergunta, "por que?" desvenda fatores que afetam diretamente o sistema em uso: i) outros mecanismos de solução de conflito disponível para uso, ii) a motivação das partes, iii) as habilidades das partes e iv) os recursos disponíveis. Não podese, contudo, esquecer que estes elementos, fatores, sujeitos e sistemas encontram-se em um contexto social, econômico, cultural específico, o que acaba afetando indiretamente o sistema de solução de conflito adotado.

Averiguar quais são as motivações das partes para utilizar este e não aquele mecanismo é uma informação essencial para o designer. Principalmente nos caso nos quais as partes utilizem-se de vias de alto custo, é crucial que se saiba o porquê dessa escolha. Quais são os benefícios trazidos por essas competições de força e de direito que são almejados pelas partes e a fazem optar por essas vias de alto custo.

Não se entende, todavia, que as partes façam necessariamente um levantamento minucioso das vias possíveis e suas caraterísticas, qualidades, custos. Muitas vezes, as

${ }^{443}$ Conforme URY, William L.; BRETT, Jeanne M.; GOLDBERG, Stephen B. Getting disputes resolved: designing systems to cut the cost of conflict. $1^{a}$ Ed. São Francisco: Jossey-Bass Publishers, 1988, p. 31. 
partes simplesmente seguem o que costuma ser feito, seguem os hábitos, sem refletir criticamente sobre suas escolhas. ${ }^{444}$

A falta de habilidades, recursos técnicos, podem ser um dos fatores para que sujeitos adotem determinadas vias, inclusive meios mais custosos de solução de conflitos.

Idealmente, as partes devem conhecer as ferramentas disponíveis, sabendo para quais hipóteses elas são mais adequadas e, eventualmente, até optar pela criação de um sistema personalizado.

Após apurada feita essa análise, caso seja constato realmente a falta ou deficiência de recursos motivacionais e técnicos, é possível a aplicação de técnicas como coaching ou training para a implementação de um novo sistema. ${ }^{445}$

\subsection{QUESTÕES PROBLEMÁTICAS DO DSD}

\subsubsection{PARTICIPAÇÃO DOS INTERESSADOS}

Por mais que o DSD busque elevar ao máximo a perspectiva do tratamento adequado de conflitos e providenciar, por meio de seus princípios e técnicas, um detalhado guia a criação ou o aperfeiçoamento de sistemas de solução de conflito, traz pontos críticos, como a figura e a atividade do designer.

Nos estudos iniciais sobre o DSD de Ury, Brett e Goldberg, ${ }^{446}$ há o posicionamento do designer no posto de expert, capaz de diagnosticar a situação, desenhar, implementar, avaliar e revisar o sistema de solução de conflito. Com isso, ele assume a

\footnotetext{
${ }^{444}$ Conforme URY, William L.; BRETT, Jeanne M.; GOLDBERG, Stephen B. Getting disputes resolved: designing systems to cut the cost of conflict. $1^{\text {a }}$ Ed. São Francisco: Jossey-Bass Publishers, 1988, p. 33.

445 Estas técnicas têm a estudo aprofundado em Conforme URY, William L.; BRETT, Jeanne M.; GOLDBERG, Stephen B. Getting disputes resolved: designing systems to cut the cost of conflict. $1^{\mathrm{a}}$ Ed. São Francisco: Jossey-Bass Publishers, 1988, p. 46.

${ }^{446}$ Como já mencionado no tópico introdutório do estudo do Desenho de Sistemas de Solução de Conflitos, a obra dos coatores Ury, Brett e Goldberg é entendida como inaugural sobre o tema. URY, William L.; BRETT, Jeanne M.; GOLDBERG, Stephen B. Getting disputes resolved: designing systems to cut the cost of conflict. $1^{\mathrm{a}}$ Ed. São Francisco: Jossey-Bass Publishers, 1988.
} 
difícil tarefa de identificar e analisar a raiz da inadequação do sistema existente, reformulálo ou, até mesmo, criar todo um novo sistema do zero.

Por mais que seja prevista no método clássico a técnica de designar um comitê para auxiliá-lo nas suas tarefas, não é dada a este grupo a importância devida. Com isso, a responsabilidade na criação de um instrumento adequado recai sobre o designer e não sobre os interessados.

Contudo, não é factível que um expert, estranho às partes, surja coletando informações a aprendendo sobre os sujeitos do conflito, assim como sobre o conflito em si, o que é ou não adequado ao interesse das partes e todo o contexto no qual essa dinâmica se desenrola.

O designer é apresentando como um médico, que examina, diagnóstica, prescreve e administra o medicamento e por fim, determina se tal tratamento teve sucesso ou não.

Este problema do modelo clássico do DSD está em não considerar a grande importância dos interessados que, mais do que exercer papéis de coadjuvantes, tem função igual ou maior que a do próprio designer no diagnóstico, desenho, implementação e revisão do instrumento.

Deve-se desenhar os sistemas com e não para os interessados. Se o designer constrói o sistema sem os interessados, eles podem ou não utilizá-lo. Já se o sistema é feito pelos interessados e pelo designer, eles não só o utilizarão, como o melhorarão, divulgarão a ideia do desenho de sistemas e seu próprio sistema, como se deles fossem, ou melhor, divulgarão seu próprio sistema, do qual, de fato, são autores. Assim, considerando os diversos aspectos do DSD, deve-se dar preferencia ao processo de criação, no qual há participação ativa dos interessados. 


\subsubsection{PRESERVAÇÃO CULTURAL}

A princípio e de uma forma simplificada, o DSD propõe que haja adequação do mecanismo ao conflito, não o oposto. Entre as etapas iniciais da criação do sistema, são levantadas as informações, como necessidades, características, interesses dos litigantes, do conflito e da conjuntura em que estes se encontram. Pretende-se preservar estes aspectos, como estruturas rígidas, moldando sobre eles o sistema.

Segundo Costantino e Merchant, o método do DSD inclui aceitar o status corrente de controle do conflito praticado e ajudar os litigantes a escolher e a implementar estratégias adequadas em uma base sistemática. ${ }^{447}$

Como já foi analisado, em muitos casos, não basta que seja desenhado e ofertado o novo sistema, é fundamental que sejam providos os recursos necessários para que as partes consigam usufruir devidamente dele e que, dessa forma, este mecanismo alcance a plenitude de seu potencial de adequação.

Considerando o exposto, a um grupo de garotos, acostumados a solucionar suas pendengas por meio de confrontos corporais, seria adequado um sistema que previsse um ringue, estipulasse regras e pontuações para suas disputas de força? Esse mecanismo vai ao encontro da dinâmica com a qual eles já estão acostumados e ainda aprimoraria as técnicas empregadas por eles. Obviamente é coerente aos costumes e aos outros conjuntos de elementos que compõem a cultura deles, mas está longe de ser um mecanismo adequado, se analisado de forma global e na perspectiva proposta pelo DSD, com seus princípios e técnicas.

Além disso, seria estipulado um padrão normativo, o conjunto de regras mencionado, alheio à cultura deles. Assim, agregar-se-iam traços de mecanismos baseados em regras, por mais que fosse mantida a preponderância da força.

${ }^{447}$ COSTANTINO, Cathy A.; MERCHANT, Christina Sickles. Designing conflict management systems. $1^{\mathrm{a}}$ Ed. São Francisco: Jossey-Bass, 1996, p. XIV. 
Se estipular local e regras para o caso já destorce, em alguma medida, a cultura existente, o que falar da introdução de um sistema consensual com base em interesses. Exigiria das partes que se adequassem ao mecanismo e não o oposto.

Estes garotos, contudo, podem adotar competições de poder para solucionar seus problemas, por mais que tenham consciência de seu malefício, por não conhecer ou saber utilizar outros mecanismos. Para tanto, deve-se verificar a razão do uso da força. Caso se verifique que há o interesse das partes em utilizar vias menos custosas, elas devem ser supridas dos os devidos recursos técnicos.

Com essa ilustração é possível constatar o desafio posto ao DSD, ou seja, introduzir um novo mecanismo, em regra, baseado no consenso e no interesse; oferecer as informações necessárias, motivação, habilidades e recursos, para que se goze plenamente dessa nova via com sua nova racionalidade; e, também, ser adequado, ou seja, respeitar os interesses e a cultura das partes. São movimentos paradoxais, já que ao mesmo tempo que é proposto algo novo, evita-se que sejam violadas as especificidades, entre as quais está a cultura dos sujeitos.

Deve ser encontrado o equilíbrio entre a introdução de novidades na forma de solucionar o conflito e as necessidades das partes e sua cultura. 


\section{PARTE II}

\section{ESTUDO DE CASO}

Após realizar a análise dos marcos teóricos relevantes ao DSD, bem como do próprio método, dá-se inicio à segunda parte desta dissertação. Nesta, serão realizados estudos de casos, visando verificar a aplicação dos institutos teóricos estudados ao plano fático.

A técnica de estudo de $\operatorname{casos}^{448}$ e o exame da aplicabilidade do DSD mostramse apropriado para a dissertação. Isto porque, o método de personalização de sistemas de solução de conflitos, em sua essência, apresenta forte relação com a efetividade e a eficiência, ${ }^{449}$ que têm sua verificação final no plano concreto. Por mais que exista a possibilidade de utilização do DSD abstratamente, a casos-tipo ou imaginários, será o grau de adequação das respostas processuais às necessidades e às peculiaridade reais das partes e do conflito o responsável pelo sucesso do mecanismo.

Consolida-se, dessa forma, a estrutura dedutiva, eleita como norte para a realização deste estudo: análise teórica sucedida pela análise de casos, ou seja, parte-se de premissas gerais e passa-se a casos pontuais, buscando verificar a validade dos padrões genéricos inicialmente postos.

Ademais, intencionando resguardar a adequada unidade e coesão do presente estudo e por ser consequência natural da estrutura dedutiva, serão construídas pontes entre os pontos teóricos apresentados na primeira parte e os fatos que serão levantados durante o estudo de casos.

Ainda dentro de uma análise metalinguística, tem-se ciência de que o método de estudo de caso não apresenta relevância estatística ou quantitativa. Pretende-se, com ele, desenvolver uma análise qualitativa dos casos.

${ }^{448}$ MARTINS, Gilberto de Andrade. Estudo de caso: uma estratégia de pesquisa. $2^{\text {a }}$ edição. São Paulo: Editora Atlas, 2008.

${ }^{449}$ Conforme analisados nos tópicos PRINCÍPIO DA EFETIVIDADE, p. 105, PRINCÍPIO DA EFICIÊNCIA, p. 107. 
Para definir os casos que seriam estudados, realizou-se um levantamento de acontecimentos que geraram conflitos complexos, interdisciplinares, com multiplicidade de sujeitos e características peculiares, aos quais o DSD poderia ter sido ou foi aplicado.

Essa busca por complexidade e especificidades deve-se exatamente à característica do método de criar respostas adequadas a cada aspecto dos sujeitos e do conflito. Alegoricamente, são desenhadas formas adaptadas a toda e qualquer ranhura do conflito, almejando o encaixe perfeito e evitando, com isso, um modelo genérico, padrão, que não atende satisfatoriamente aos conflitos complexos. ${ }^{450}$

Com essa pesquisa prévia, chegou-se a questões indenizatórias fundadas em responsabilidade objetiva ou de baixo questionamento quanto à responsabilidade civil, mas, ainda assim, sob a influência de diversos vetores multidisciplinares, como psicológicos, econômicos, empresariais, públicos, administrativos, ambientais. ${ }^{451}$

Por fim, foram selecionados os seguintes casos: Câmara de Indenização Voo 3054 (CI3054) e o Programa de Indenização Voo 447 (PI447). Mais do que acontecimentos geradores de conflitos complexos, houve, nestes casos, a aplicação efetiva do método do DSD, com a criação de mecanismos de solução de conflitos personalizados.

Constatou-se que se alcançaria uma análise mais rica e real, se fossem escolhidos casos nos quais houve o concreto emprego do método. Dessa forma, não se trabalharia apenas com dados teóricos e suposições quanto a sistemas que não existiram, mas sim, com informações e resultados concretos de um sistema que realmente existiu.

Além disso, destaca-se que, entre os critérios adotados para tal seleção, está a relevância dos casos para o campo de estudo dos meios adequados de solução de conflitos

450 "One size does not fit all when it comes to complex conflicts". FALECK, Diego. Introdução ao Design de Sistemas de Disputas: Câmara de Indenização 3054. In Revista brasileira de arbitragem, Ano V, n. 23 São Paulo: IOB, 2009, p. 7.

${ }^{451}$ Entre os casos não selecionados, mas com pertinência para o tema, estão a explosão do Osasco Plaza Shopping, em 1996, que matou 42 pessoas e feriu 372 (http://blogs.estadao.com.br/arquivo/2011/06/11/ha15-anos-explosao-do-osasco-plaza-shopping/), o naufrágio do Bateau Mouche que trouxe a óbito 55 das 142 pessoas que estavam a bordo (http://www1.folha.uol.com.br/folha/cotidiano/ult95u483896.shtml) e algumas áreas listadas pela CETESB como de contaminação crítica na grande São Paulo, por exemplo, o condomínio Barão de Mauá, Shopping Center Norte e a região de Jurubatuba (http://www.cetesb.sp.gov.br/areascontaminadas/rela\%C3\%A7\%C3\%B5es-de-\%C3\%A1reas-contaminadas/17-jurubatuba http://g1.globo.com/sao-paulo/noticia/2011/09/cetesb-recomenda-retirada-de-moradores-de-areacontaminada.html). 
(ADRs) brasileiro, em especial, ao subcampo do DSD. A CI3054 é apresentada como sendo o leading-case deste método no Brasil. ${ }^{452}$

Os casos analisados apresentam sistemas de solução de conflito que têm forte ligação. Além de terem como objeto conflitos semelhantes, tiveram o mesmo designer. ${ }^{453}$ Ademais, a CI3054 encerrou seus trabalhos em junho de 2009, poucos dias após a tragédia com o voo Air France 447, em 31 de maio de 2009. Como ainda será mais bem analisado, pode-se afirmar que as experiências adquiridas ao longo da implementação e das atividades da CI3054, foram aproveitadas para o PI447, diminuindo seus custos.

Por essa razão, optou-se por desenvolver o estudo sobre estes dois casos conjuntamente. Entende-se que, dessa forma, alcançar-se-ia uma análise comparativa mais frutífera e menos repetitiva.

A análise terá início com a apresentação fática, com um relato histórico do ocorrido. Posteriormente, serão analisados quais são os principais mecanismos existentes para a solução de conflitos desse tipo. Por fim, passar-se-á pelos aspectos do conflito e suas respectivas respostas processuais.

A oferta de informações sobre os sistemas da CI3054 e do PI447 é limitada, devido à fundamentação deles no sigilo. Dessa forma, a análise dos casos dar-se-á por meio de artigos jornalísticos de veículos de comunicação de grande circulação e pelos documentos públicos disponibilizados por estes sistemas, como seus regimentos internos. $^{454}$

452 "O Brasil, surpreendentemente, antecipando-se à maioria das nações desenvolvidas, apesar do relativamente tímido desenvolvimento no campo de ADR, teve um leading-case de DSD, com o exemplo recente da criação da Câmara de Indenização 3054 (CI 3054), concebida para implementar meio eficiente e justo de indenizar os beneficiários das vítimas do terrível acidente de 17 de julho de 2007, com o voo TAM 3054, em que 199 pessoas perderam as vidas”. FALECK, Diego. Introdução ao Design de Sistemas de Disputas: Câmara de Indenização 3054. In Revista brasileira de arbitragem, Ano V, n. 23 São Paulo: IOB, 2009 , p. 9.

${ }^{453}$ Diego Faleck, então chefe de gabinete da Secretaria de Direito Econômico (SDE) do Ministério da Justiça. ${ }^{454}$ Para uma melhor compreensão do estudo, tanto o regimento interno da CI3054, como o do PI447 seguem anexos à dissertação. 


\section{VOO TAM 3054 E VOO AIR FRANCE 447}

\subsection{DESCRIÇÃO FÁTICA DOS ACIDENTES}

No inicio da noite do dia 17 de julho de 2007, a aeronave ${ }^{455}$ da companhia aérea TAM, que havia decolado do Aeroporto Salgado Filho em Porto Alegre - RS, não parou após pousar no aeroporto de Congonhas, ${ }^{456}$ extrapolou os limites da pista, atravessou a Avenida Washington Luís e colidiu com o prédio de quatro andares da TAM Express, subsidiária da mesma companhia aérea, e com um posto de gasolina, causando um incêndio de grandes proporções. ${ }^{457}$

Todos os 187 ocupantes da aeronave não sobreviveram. Houve também o falecimento de 13 pessoas em terra. Com as 199 vítimas fatais, este acidente tornou-se o maior da América Latina. Título mantido até 31 de maio de 2009, quando houve o acidente do voo Air France $447,{ }^{458}$ segundo acidente a ser analisado.

Por volta das vinte e três horas do dia 31 de maio, a aeronave ${ }^{459}$ da companhia aérea francesa que fazia o trajeto Rio de Janeiro - Paris desapareceu sobre Oceano Atlântico, em águas internacionais. ${ }^{460}$ Destroços do avião e manchas de óleo foram avistados dois dias depois, quando as autoridades oficializaram o acidente. Também neste caso, não houve sobreviventes. Todas as 228 pessoas a bordo, dos quais 216 passageiros e 12 tripulantes, morreram. Desses 228 corpos, foram resgatados 52, após 26 dias de buscas. Aproximadamente dois anos depois, as buscas foram retomadas. Tiveram como resultado o resgate de mais 102 corpos, totalizando 154. Deixaram, contudo, 74 que, conforme

\footnotetext{
455 Airbus A320-233

${ }^{456} \mathrm{Na}$ época do acidente, o Aeroporto de Congonhas, situado em uma região urbana, densamente povoada e com importantes avenidas da capital paulista, era o maior do Brasil em movimento, recebendo, apenas no período de janeiro a julho de 2007, 122.890 aeronaves e 10.072.300 passageiros conforme informações da INFRAERO (Empresa Brasileira de Infraestrutura Aeroportuária). O aeroporto operava a uma taxa de 18 milhões de passageiros anuais, enquanto sua capacidade era de 12 milhões, um acréscimo de 50\%. (http://www.infraero.com.br/images/stories/Estatistica/2007/mov.\%20operac._0707_revisado.pdf http://www1.folha.uol.com.br/folha/cotidiano/ult95u320615.shtml).

${ }^{457}$ Ver http://www1.folha.uol.com.br/folha/especial/2007/voo3054/

${ }^{458}$ Ver http://www1.folha.uol.com.br/especial/2009/Air Francevoo447/

459 Airbus A330-200

${ }^{460}$ Em relatório da agência do governo francês responsável pela investigação de acidentes aéreos, BEA (Bureau d'Enquêtes et d'Analyses pour la Sécurité de l'Aviation Civile), divulgado em 29 de julho de 2011, aponta como as causas do acidente uma série de falhas técnicas e erros humanos. (http://media.folha.uol.com.br/cotidiano/2011/07/29/acidente_airbus.pdf)
} 
critérios de resgate determinados pela justiça francesa, não tinha condições adequadas de identificação, nem de serem entregues decentemente aos familiares. ${ }^{461}$

Desde já, salienta-se que estas duas tragédias, apesar de semelhantes, apresentam algumas diferenças relevantes. Entre estas estão as que envolvem a nacionalidade dos sujeitos. O voo TAM 3054 era doméstico, com quase a totalidade dos passageiros de nacionalidade brasileira, enquanto o voo Air France 447 era internacional, tendo apenas 58 brasileiros a bordo, aproximadamente, $25 \%$ do total de ocupantes da aeronave. $^{462}$

Antes de terminar a descrição fática, será feito um rápido relato sobre o contexto no qual estas tragédias deram-se.

$\mathrm{O}$ acidente com a aeronave da TAM ocorreu em um momento em que o setor aéreo já se encontrava em crise. Voos atrasados, cancelamentos, problemas com os controladores de tráfego aéreo e outros de cunho estrutural e político estavam entre os assuntos diários nos meios de comunicação. ${ }^{463}$ Nas duas casas do legislativo federal, existiam as chamadas CPIs ${ }^{464}$ do Apagão Aéreo. ${ }^{465}$ Levantavam-se ainda questões quanto ao grooving da pista do aeroporto de Congonhas. ${ }^{466}$

Por mais que estes problemas já existissem há algum tempo, tomaram maior proporção com a colisão, no ar, de um Boeing da companhia aérea Gol e o jato Embraer Legacy 600, em 29 de setembro de 2006. Esse choque causou a queda do Boeing em uma

461 Conforme notícia veiculado BBC Brasil no dia 07 de junho de 2011. Disponível em: http://www.bbc.co.uk/portuguese/noticias/2011/06/110607 Air France df rc.shtml http://www.estadao.com.br/noticias/impresso,air-france-74-corpos-nao-serao-resgatados, 729375,0.htm. ${ }_{462}$ As 228 vítimas eram de 32 nacionalidades diferentes. http://veja.abril.com.br/noticia/brasil/governofrances-autoriza-busca-de-corpos-do-af-447

${ }^{463}$ Conforme notícia disponível em: http://noticias.terra.com.br/brasil/criseaerea

${ }^{464}$ A sigla "CPI" é referente à "Comissão Parlamentar de Inquérito".

${ }^{465}$ No Senado, tramitava a CPI do "apagão aéreo", enquanto na Câmara dos Deputados, existia a CPI da crise do sistema de tráfego aéreo. Os relatórios finais estão disponíveis, respectivamente, em: (http://www.senado.gov.br/atividade/materia/getPDF.asp?t=56362) e (http://www2.camara.gov.br/atividadelegislativa/comissoes/comissoes-temporarias/parlamentar-de-inquerito/53a-legislaturaencerradas/cpiaereo/CPIAEREO_RelFinal_REVFinal1.pdf).

${ }^{466} \mathrm{O}$ termo "grooving" é um jargão do setor aéreo utilizado para denominar as ranhuras na pista responsável em aumentar sua aderência e melhorar sua drenagem. (http://www1.folha.uol.com.br/folha/cotidiano/ult95u326164.shtml). 
área de densa vegetação da floresta amazônica na Serra do Cachimbo, na região norte do estado de Mato Grosso, vitimando todos os 154 ocupantes. ${ }^{467}$

Desse modo, a população já estava com sua atenção voltada ao setor aéreo quando ocorreu mais esse acidente, desta vez, em São Paulo. O que se pretende transmitir com essa contextualização é que existia especial comoção social e forte pressão sobre as autoridades, quando do advento do acidente com o voo 3054 da TAM.

Já no caso do acidente de maio de 2009 com o avião da Air France, apesar de se vir de uma série de acidentes aéreos: setembro de 2006, julho de 2007 e maio de 2009, a crise do setor aéreo não estava mais com o mesmo destaque de 2007.

\subsection{CÂMARA DE INDENIZAÇÃO VOO 3054 (CI3054) E PROGRAMA DE INDENIZAÇÃO VOO 447 (PI447)}

Pretende-se com o presente item dar informações introdutórias sobre a CI3054 e o PI447, para facilitar o entendimento das próximas etapas que serão abordadas ao longo do estudo desses casos.

A Câmara de Indenização Voo 3054 (CI3054) foi oferecida aos familiares e outros beneficiários do acidente aéreo que ocorreu com uma aeronave da companhia aérea TAM, em julho de 2007 em São Paulo, como uma via para que recebessem a devida indenização. ${ }^{468}$ Este mecanismo tinha a pretensão de ser não só mais uma alternativa, ${ }^{469}$ mas sim um meio especialmente desenhado para o tratamento dos conflitos originados pela

\footnotetext{
${ }^{467} \mathrm{http}: / /$ www1.folha.uol.com.br/folha/especial/2006/voo1907/

468 "Art. 1'. Fica implementada a Câmara de Indenização TAM Voo 3054 ("Câmara"), com o objetivo de colocar à disposição das pessoas que têm legitimidade para receber indenização ("Beneficiários"), em virtude do acidente ocorrido em 17 de julho de 2007 ("Evento"), em São Paulo - SP, uma opção para o recebimento dos valores a que fazem jus, de forma célere e efetiva". Regimento Interno - Câmara de Indenização Voo 3054, p. 6.

${ }^{469}$ Como será desenvolvido no tópico SISTEMAS , p. 184, além da Câmara de Indenização Voo 3054, os possíveis beneficiários podiam pleitear suas respectivas indenizações por meio de ações judiciais no Brasil e no estrangeiro e em acordos diretamente firmados com as empresas responsáveis.
} 
referida tragédia. Visava-se ter um sistema, criado a partir dos princípios e técnicas do $\mathrm{DSD},{ }^{470}$ para solucionar as questões de forma célere, efetiva e satisfatória para as partes.

Proposta inicialmente pela Secretaria de Direito Econômico (SDE) do Ministério da Justiça, a ideia de instituir a câmara foi apresentada a outras autoridades integrantes do Sistema Nacional de Defesa do Consumidor (SNDC), ${ }^{471}$ em especifico, ao Ministério Público do Estado de São Paulo (MP-SP), Defensoria Pública do Estado de São Paulo, Fundação PROCON do Estado de São Paulo. Uma vez com o apoio das autoridades públicas, o projeto foi levado aos familiares das vítimas, organizados em estrutura de associação, AFAVITAM, ${ }^{472}$ e às empresas responsáveis pelo pagamento das indenizações, TAM e suas seguradoras e ressegurados, representadas pela seguradora Unibanco AIG.

Após reuniões, negociações, um compromisso para compor os interesses e necessidades foi firmado por meio de um Termo de Ajustamento de Conduta (TAC).

Este processo metalinguístico, que tem como objeto o próprio processo, sua criação, desenho, adequação e adoção, refere-se ao primeiro consenso existente no DSD, conforme classificado neste estudo. ${ }^{473}$ Nesta tratativa, há a tutela coletiva dos interesses individuais homogêneos por meio da substituição processual dos consumidores pelas autoridades públicas.

Com princípios como voluntariedade, sigilo e celeridade registrados no regimento interno e manual de orientação, ${ }^{474} 475$ surgiu, depois de nove meses do acidente,

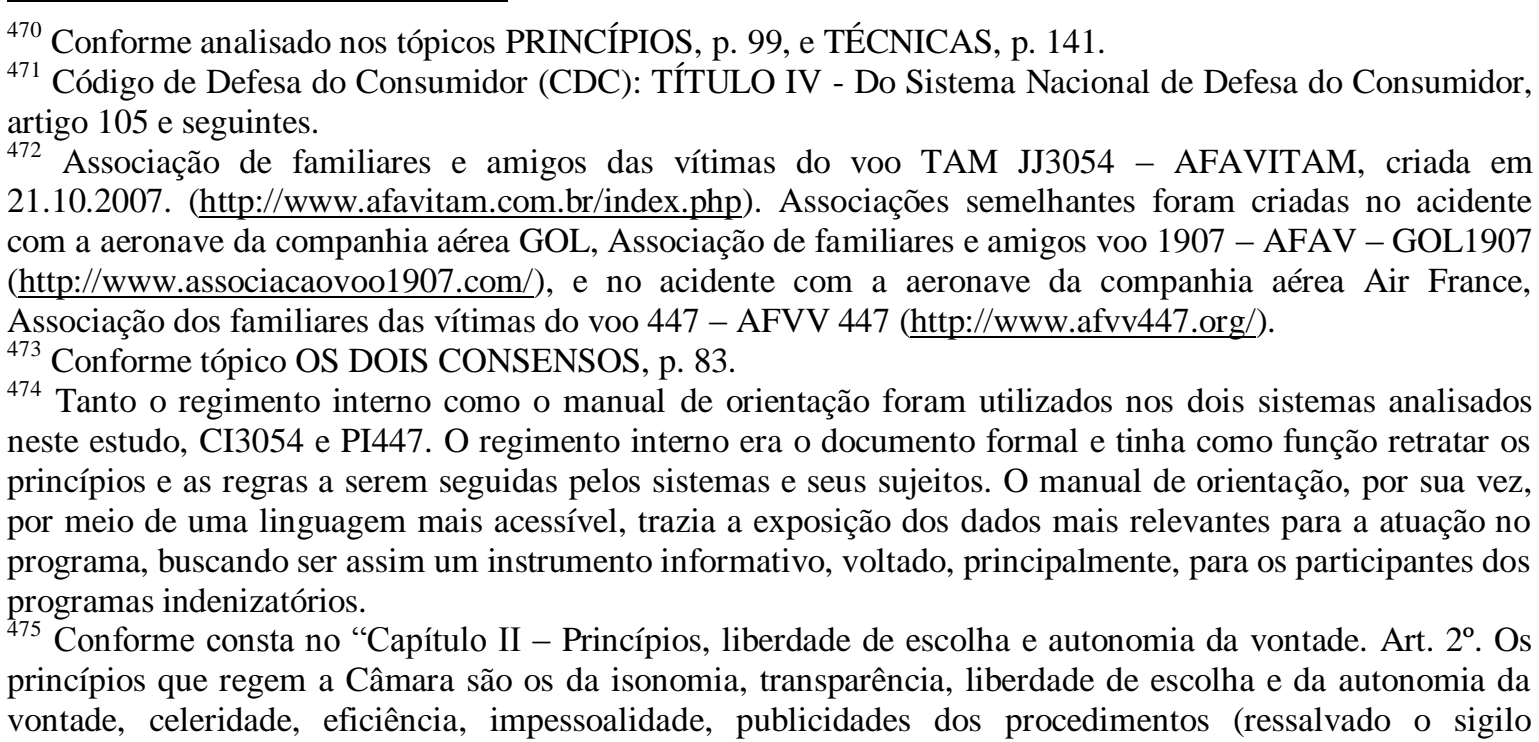


mais uma via pela qual os legitimados poderiam pleitear e receber os valores indenizatórios. A CI3054 começou suas atividades em 24 de abril de $2008 .{ }^{476}$

A estrutura da câmara contava com observadores e assistentes, encarregados, entre outras funções, de oferecer informações sobre o sistema, seus princípios e procedimento. ${ }^{477}$ Os beneficiários que apresentavam interesse pela via davam entrada por meio de um formulário de ingresso, juntando também a documentação relevante, ${ }^{478}$ como certidão de casamento e extratos bancários. Esse dossiê era analisado pelos advogados da TAM e sua seguradora.

Posteriormente, realizava-se uma reunião, mediada pelos observadores, ${ }^{479}$ entre os beneficiários, assistidos ou não de advogado, ${ }^{480}$ e os representantes da companhia aérea e da seguradora.

Este encontro poderia ter duas finalidades. Caso as empresas chegassem ao entendimento de que os dados apresentados não eram suficientes para a elaboração de uma proposta, a reunião teria como objetivo a coleta de mais informações. Por exemplo, buscavam-se esclarecimentos quanto á legitimidade, ou ainda quanto à renda da vítima, à dependência do beneficiário ou qualquer outra circunstância que tenha impedido o cálculo do valor a ser indenizado. Na hipótese contrária, sendo suficientes as informações obtidas com as documentações entregues, era apresentada a proposta de indenização referente àqueles beneficiários.

necessário à preservação da intimidade dos envolvidos), moralidade, distributividade, pleno acesso, racionalidade, razoabilidade, promoção dos valores de honestidade e comunidade, fortalecimento da sociedade cívica e da cidadania e dignidade da pessoa humana". Regimento Interno - Câmara de Indenização Voo 3054, p. 6.

${ }^{476}$ Conforme Balanço de atividades - Câmara de indenização 3054, 2009, p. 6.

${ }^{477}$ Conforme consta do "Capítulo V- Divisão de Assistência e Conselho dos Órgãos do Sistema Nacional de Defesa do Consumidor", em especial, do artigo $10^{\circ}$ do Regimento Interno - Câmara de Indenização Voo 3054 , p. 8.

${ }^{478} \mathrm{O}$ artigo 22 do Regimento Interno trazia um rol de informações e documentos relevantes ao procedimento de ingresso do interessado na Câmara. Regimento Interno - Câmara de Indenização Voo 3054, p. 14.

${ }^{479}$ O Regimento Interno previa e o Manual de Orientação esclarecia, no art. $10^{\circ}$, $\$ 3^{\circ}$ e no item 12 , respectivamente, a possibilidade de o beneficiário optar pela não participação de observadores e/ou assistentes nas reuniões com o representante das empresas. Nestas hipóteses, previa-se que essa manifestação deveria se dar na forma escrita. Regimento Interno - Câmara de Indenização Voo 3054, p. 9 e Manual de Orientação - Câmara de Indenização Voo 3054, p. 9.

480 “Art. 17. Os Beneficiários poderão, a seu exclusivo critério, fazer-se acompanhar por advogado para representá-los perante a Câmara”. Regimento Interno - Câmara de Indenização Voo 3054, p. 12. 
Qualquer que fosse o objetivo da reunião, sempre era possível que fossem levantadas circunstâncias excepcionais ou mesmo alguma peculiaridade do caso em debate para a individualização e reanálise dos valores indenizatórios.

Os cálculos para essas propostas de acordo eram feitos com base nos parâmetros referenciais. Estas diretrizes foram compostas com base na legislação vigente e, principalmente, na jurisprudência do STJ - Superior Tribunal de Justiça. Este instrumento é uma marca forte da aplicação das técnicas e princípios do DSD. ${ }^{481}$

Nessas reuniões, como mencionado, estavam também presentes os observadores. Eles eram os "olhos e ouvidos" das autoridades públicas e funcionavam como mediadores, transitando entre diferentes mecanismos consensuais, mediação facilitativa e a avaliativa, ${ }^{482}$ ou seja, auxiliavam na comunicação das partes e, quando necessário, avaliavam as propostas à luz do previsto nos parâmetros referências.

No mês de julho de 2009, a CI3054 finalizou suas atividades ${ }^{483}$ com uma taxa de $92 \%$ de solução, considerando os casos que haviam ingressado no sistema. ${ }^{484}$

Faltando poucos dias para o encerramento da CI3054, mais uma tragédia aérea ocorreu. A queda do avião da Air France tornava-se, assim, mais um polo deflagrador de inúmeros conflitos e no qual poderia se aproveitar a estrutura idealizada e implementada na

\footnotetext{
${ }^{481}$ Os parâmetros referenciais já foram analisados entre as possíveis técnicas do DSD. PARÂMETROS REFERENCIAIS, p. 155.

${ }^{482}$ Conforme análise das de vias consensuais já desenvolvida no tópico RACIONALIDADE DOS MECANISMOS CONSENSUAIS, p. 61, os observadores tinham entre suas funções tanto facilitar a comunicação das partes, garantindo "o bom desenvolvimento dos trabalhos na Câmara" (item 11 do Manual de Orientação - Câmara de Indenização Voo 3054, p. 8); como avaliar se as tratativas estavam respeitando o regimento interno e os parâmetros referenciais, como também se estavam sendo "mantidos o equilíbrio e razoabilidade na avaliação e consideração das informações e documentos para o cálculo da indenização" (item 11 do Manual de Orientação - Câmara de Indenização Voo 3054, p. 8), avaliando ainda se não havia a pertinência de se realizar uma consulta às autoridades públicas (art. $10^{\circ}$, $\$ 2^{\circ}$, inciso IV e art. 31 , Regimento Interno - Câmara de Indenização Voo 3054, páginas 9 e 18, respectivamente). O artigo $9^{\circ}$, inciso IV do interno do Programa de Indenização Voo 447 traz a seguinte disposição quanto à função dos observadores e assistentes: "com o papel de encorajar a troca de informações entre os interessados, ajudá-los a entender as perspectivas de cada uma das partes envolvidas, promover um nível produtivo de expressão emocional, ajudar as partes a avaliar realisticamente as alternativas existentes, encorajar flexibilidade, estimular as partes à sugestão de soluções criativas para os impasses, e sugerir soluções que satisfaçam os interesses principais dos envolvidos". Regimento Interno - Programa de Indenização Voo 447, p. 7.

483 Balanço de atividades - Câmara de Indenização 3054 - 2009. (http://www.defensoria.sp.gov.br/dpesp/Repositorio/0/Documentos/CCSAI/relatorio_camara02.pdf).

${ }_{484}$ Dos 59 requerimentos de ingresso, 55 fecharam acordo, $92 \%$ de sucesso. Esses números representam a indenização de 207 beneficiários referentes a 45 vítimas. Balanço de atividades - Câmara de Indenização $3054-2009$, p. 20.
} 
CI3054, bem como as experiências adquiridas ao longo da aplicação do DSD ao acidente que aconteceu em Congonhas.

É apropriado relembrar que uma das técnicas do DSD é a constante avaliação do sistema. Busca-se com ela sanar eventuais inadequações.

Quanto a isso, o regimento interno da CI3054 mencionava expressamente a realização de reuniões entre às autoridades públicas e a empresa aérea para "deliberarem sobre os casos omissos, assim como sobre eventuais correções e adaptações necessárias para o bom andamento dos trabalhos da Câmara e observância dos objetivos e princípios previstos neste Regimento". ${ }^{485}$ Desse modo, pode-se afirmar que o sistema da CI3054 passou por aperfeiçoamentos durante sua existência, não sendo, ao seu término, idêntico ao seu estado inicial.

Assim, com o aproveitamento das informações obtidas com a CI3054, a versão inicial do sistema do Programa de Indenização Voo 447, utilizado no caso do acidente com o Air France, já trazia as melhorias e correções aplicadas ao primeiro sistema. Tem-se, com isso, a utilização racional dos recursos e a não repetição de custos, presando pela eficiência proposta pelo DSD, sem violar a customização do sistema.

A experiência da CI3054, juntamente com seus resultados positivos, foi levada às autoridades cariocas, familiares, empresa aérea e seguradora, visando à criação do PI447. ${ }^{486}$

A apresentação de exemplos de sucesso é uma forma de motivar e ofertar informação às partes, auxiliando-as no seu convencimento quanto à adoção do mecanismo. ${ }^{487}$ Esta prática está entre as técnicas de motivação do DSD.

\footnotetext{
${ }^{485}$ Art. $9^{\circ}$ do Regimento Interno - Câmara de Indenização Voo 3054, p. 8.

${ }^{486}$ O PI447 foi integrado pela Société Air France (Air France), suas seguradoras e resseguradoras, representadas pela seguradora líder, AXA Corporate Solutions (AXA) e pelos órgãos componentes do Sistema Nacional de Defesa do Consumidor: Ministério Público do Estado do Rio de Janeiro (MP/RJ), Fundação Procon/RJ (PROCON/RJ) e Secretaria de Direito Econômico do Ministério da Justiça (SDE/MJ). ${ }^{487}$ Entre as formas de motivação dos sujeitos para adesão está a divulgação de casos exitosos. "Publicizing early sucesses of the new dispute resolution system gives momentum to the change process". URY, William L.; BRETT, Jeanne M.; GOLDBERG, Stephen B. Getting disputes resolved: designing systems to cut the cost of conflict. $1^{\text {a }}$ Ed. São Francisco: Jossey-Bass Publishers, 1988, p. 77.
} 
Enfrentando menor desconfiança, uma vez que não se tratava mais da primeira aplicação do método do DSD, o Programa de Indenização Voo 447 foi instaurado. Com princípios semelhantes ao da CI3054, ${ }^{488}$ o Programa de Indenização Voo 447 teve início em 10 de dezembro de 2009, sete meses após o acidente, com a participação da Société Air France (Air France), suas seguradoras, representadas pela seguradora líder, AXA Corporate Solutions (AXA), o Ministério Público do Estado do Rio de Janeiro (MP-RJ), Fundação PROCON do Estado do Rio de Janeiro e a Secretaria de Direito Econômico, do Ministério da Justiça (SDE/MJ), integrantes do Sistema Nacional de Defesa do Consumidor.

Este programa também apresentava em sua estrutura uma divisão de assistência, composta por observadores e assistentes, para auxiliar e acompanhar as tratativas dos pleiteantes e as empresas responsáveis pela indenização.

De forma geral, os procedimentos e respostas processuais encontradas para o adequado tratamento e solução dos conflitos nos dois sistemas são semelhantes.

\subsubsection{SISTEMAS EXISTENTES}

Não é a primeira vez que tragédias como as analisadas ocorreram. Ainda que, no passado, não se tenha elaborado um sistema personalizado, sempre se encontram caminhos para buscar a solução dos conflitos provenientes desses acidentes.

O desenho dos sistemas estudados, não limitou ou excluiu opções de mecanismos para a solução de conflito, mas sim, adicionou mais uma às existentes.

$\mathrm{Na}$ busca pela devida indenização, como primeira via, os familiares e outras pessoas que se entendem legítimas para recebê-las tendem a entrar em contato direto com

\footnotetext{
${ }^{488} \mathrm{O}$ artigo $2^{\circ}$ do Regimento Interno do Programa de Indenização Voo 447 trazia os seguintes princípios: “Art. $2^{\circ}$. O PI 447 é regido pelos princípios da isonomia, transparência, liberdade de escolha, autonomia da vontade, eficiência, razoabilidade, promoção dos valores sociais de honestidade e comunidade, fortalecimento da sociedade cívica e da cidadania e dignidade da pessoa humana". Regimento Interno Programa de Indenização Voo 447, p. 5.
} 
os responsáveis pelo pagamento dos valores. Dessa forma, por meio de tratativas negociais, as partes tentam apurar o valor devido, quitá-lo e compor o conflito.

Como principais benefícios desse sistema, pode-se apontar a celeridade na solução, a tendência de simplicidade ou menor formalidade e a confidencialidade, uma vez que não há a participação de terceiros ou publicidade das tratativas.

Contudo, nem sempre se alcança êxito, uma vez que as questões a serem superadas não costumam ser simples. Há dificuldades para se apurar a legitimidade dos pleiteantes, assim como para definir os valores indenizatórios referentes aos danos moral e material.

Os custos para a aquisição destas informações, juntamente com a insegurança de tratativas negociais entre sujeitos com grande disparidade de poder, fazem com que, muitas vezes, a negociação seja abandonada em prol da adjudicação estatal. Aponta-se que “a negociação direta costuma ser seguida de promoção de demanda judicial em $60 \%$ (sessenta por cento) dos casos". 489

O encaminhamento da questão para a via judicial não afasta a existência de variáveis. Entre estas, há a possibilidade de se demandar no Brasil, bem como em outros países.

Para realizar sua opção, o sujeito terá que analisar seus interesses e os benefícios que podem ser obtidos nos sistemas dos diferentes países. Obviamente, um dos primeiros filtros que se deve analisar são as regras de competência, que pode, contudo, ser superada, encontrando foros com competência concorrente, a depender das regras do ordenamento estrangeiro.

Como ilustração, pode-se pensar em um indivíduo que, na expectativa de receber uma indenização milionária em decorrência dos punite damages, pleiteia-a nos Estados Unidos, considerando sua fama quanto a estes valores. Em outro exemplo, uma

489 TARTUCE, Fernanda. Mediação extrajudicial e indenização por acidente aéreo: relato de uma experiência brasileira. In Lex Humana, v. 4, n. 1, 2012, p. 33 
grande corporação empresarial opera de modo a ter seus casos tratados em localidades onde terão a menor repercussão possível.

Este fenômeno, no qual os indivíduos escolhem o foro em que terão seus conflitos processados, visando benefícios ou mitigando prejuízos, é chamado de fórum shopping.

A despeito disso, o sistema americano pode arruinar esta estratégia processual, afastando a proibição do non liquet e declarando-se foro não conveniente (fórum non conveniens). ${ }^{490}$

Além do mais, o fato de se demandar, não implica deferimento do pleito.

Em paralelo a esta incerteza quanto ao sucesso, cabe às partes também calcular que a demora do processamento da questão em um local pode prejudicar o processamento em outro. Isto significa, exemplificativamente, que uma pessoa que proponha sua ação apenas nos Estados Unidos, pode ter sua pretensão prescrita no Brasil antes que haja uma decisão judicial final dos órgãos americanos, correndo ainda o risco de esta ser pela improcedência da demanda.

A adoção de foros estrangeiros aumenta os custos de transação, já que surgem, por exemplo, questões de deslocamento, contratação de advogados estrangeiros e desconhecimento do ordenamento jurídico do país.

Por fim, pode-se ainda optar pelo judiciário nacional, com características que, em parte, contrapõem-se à negociação direta, como a maior segurança jurídica, maior formalidade e menor celeridade.

Neste tópico, buscou-se abordar apenas os mecanismos que se entendem mais utilizados quando de tragédias como as analisadas.

\footnotetext{
490 "It is a fact that plaintiffs will almost always select a forum in which they believe they will maximize their recovery, as long as they have a reasonable chance of remaining in that forum, and that forum is often within the U.S. Conversely, defendants will generally seek to relegate actions to the forum in which they believe their exposure is minimized, and that forum is often outside of the U.S". Conforme decisão judicial americana no caso do acidente aéreo entre uma aeronave da GOL e um jato Legacy em 29 de setembro de 2006: case 1:07-md-01844-bmc-jo, document 152, disponível em: http://boardingarea.com/joesharkey/files/2008/07/brazil-jul-08.pdf
} 


\subsubsection{ASPECTOS DO CONFLITO E SUAS RESPOSTAS}

A criação de um sistema de solução de conflito personalizado, baseado na perspectiva dos mecanismos adequados e do método do DSD, depende, como um dos seus elementos iniciais, da aquisição de informações relativas à situação conflituosa. Devem ser examinados seus aspectos à busca de peculiaridades, complexidades e outras características que demandem respostas processuais adequadas e, por essa razão, guiarão o desenho do sistema. Este levantamento é feito pelo designer, com o auxílio dos interessados.

Os dois casos estudados, voo TAM 3054 e voo Air France 447, apresentam grande similitude. Os dois são acidente aéreo de grandes proporções e sem sobreviventes.

Essa espécie de acontecimentos tende a lesionar diferentes facetas dos interesses dos sujeitos: emocionais, familiares, sociais, econômicos, jurídicos, entre outras. Isto contribui para a complexidade dos conflitos deles provenientes.

Devido à magnitude e multiplicidade dos efeitos, estes desastres, além de alcançarem diretamente as vítimas, seus familiares e beneficiários, alcançam indiretamente toda a sociedade.

Como já mencionado quanto da descrição fática dos acidentes, ${ }^{491}$ devido à própria natureza destes e a razões circunstanciais, como a crise aérea, despertaram especial interesse social. Essa afirmação não remete apenas aos sentimentos, à comoção social, mas também, ao interesse político e jurídico nas investigações das responsabilidades. Há atentados às diretrizes consumeristas, à segurança do transporte aéreo, dos consumidores e da sociedade como um todo. ${ }^{492}$

Estes fatores tiveram o condão de dar origem a uma característica peculiar e forte dos programas de indenização criados, que é a presenças das autoridades públicas. Paralelamente a outras medidas previstas em lei para a tutela de interesses individuais

${ }^{491}$ DESCRIÇÃO FÁTICA DOS ACIDENTES, p. 177.

492 A perspectiva social das duas ocorrências é extremamente rica, trazendo consigo diversos questionamentos. Contudo, a análise destes desvirtuaria este estudo do seu tema inicial. Dessa forma, a perspectiva social será analisada na medida em que legitimam as autoridades públicas a atuar nos casos. 
homogêneos, as autoridades não só optaram, como tomaram a iniciativa na aplicação de uma medida nova, o DSD.

Não se afasta, todavia, o provável desafio no convencimento dos diferentes órgãos estatais, tendo em vista o desconhecimento do método e o ineditismo do projeto.

As autoridades participaram efetivamente dos sistemas, fiscalizando e legitimando-os. Estas funções iam ao encontro dos interesses dos sujeitos do conflito.

Por um lado, esta participação contribuiu com o interesse dos legitimados ativos das pretensões indenizatórias contra as empresas aéreas, como instrumento de equalização da relação. Assim, teve o condão de equilibrar ou, ao menos, minorar o natural desiquilíbrio existente entre os consumidores e os fornecedores de produtos e serviços.

Por outro lado, é possível que, em alguma medida, a presença de fiscais e legitimadores também fosse do interesse das companhias, uma vez que isso aumentava a segurança do sistema. Esta maior segurança é uma característica benéfica para todas as partes, por reduzir os custos do sistema.

Contudo, frente à complexidade dos sujeitos e seus interesses, é provável que também existissem entre os interesses das empresas indenizadoras vetores contrários à participação das autoridades no sistema. A presença desses atores reduziu os efeitos da vantagem de poder delas, sendo, desse modo, necessário novos cálculos das possibilidades de conduta.

Os sistemas personalizados, apesar da sua adequação e com níveis baixos de costs of dispute, ${ }^{493}$ apresentam custos, sendo imprescindíveis recursos financeiros, técnicos, humanos.

$\mathrm{O}$ artigo $4^{\mathrm{o}}$, inciso $\mathrm{V}$ do Código de Defesa do Consumidor atribui ao fornecedor a criação de mecanismos adequados de solução de conflito. Depreende-se da norma, que esta criação dar-se-á às suas custas. $\mathrm{O}$ artigo $7^{\circ}$ do regimento interno de ambos

${ }^{493}$ Conforme tópico CUSTOS DO TRATAMENTO DO CONFLITO (COSTS OF DISPUTING), p. 114. 
os sistemas dispunha que cabia às empresas aéreas, no caso do PI447, cabia ainda à seguradora, custear as instalações e o pessoal.

Os recursos técnicos para a utilização do sistema tinham origem preponderantemente nos órgãos públicos, com a capacitação dos observadores e assistentes. Paralelamente, as empresas tinham as suas equipes de advogados, enquanto os consumidores poderiam optar pela assistência de advogados. Na CI3054, 78\% dos familiares estavam assistidos. Os honorários destes profissionais eram posteriormente pagos pelas companhias. ${ }^{494}$

Ainda na análise dos atores, existia também o desafio de identificar os titulares dos direitos indenizatórios, ou seja, era necessário definir a quem deveriam ser pagas as indenizações. Para tanto, tinha-se que verificar a legitimidade dos pleiteantes.

Em um primeiro momento, o rol de legítimos é indeterminado. Isso porque, nas tragédias em questão, os valores não serão pagos para as pessoas diretamente atingidas pelo dano, uma vez que não houve sobreviventes. Por essa razão, é necessário analisar o vínculo entre o indivíduo que alega ser legítimo e a vítima do acidente.

Como já analisado, ${ }^{495}$ a comprovação desta condição pode não ser tão simples quanto à apresentação de um documento lavrado em cartório. Existem situações fáticas, tuteladas juridicamente pelo ordenamento, mas não formalizadas, como um noivado ou uma união estável.

Como resposta para essa questão, buscando equilibrar os custos de critérios rígidos ou muito frouxos, os sistemas facilitaram o ingresso, por meio da legitimidade automática. Esta era prevista apenas ao núcleo familiar próximo, compostos por pais, filhos, cônjuges, irmão e, desde que preenchidos certos requisitos, companheiros. ${ }^{496}$

\footnotetext{
${ }^{494}$ Conforme artigo 51, parágrafo $5^{\circ}$ do regimento interno do PI447. Regimento Interno - Programa de Indenização Voo 447, p. 22.

${ }^{495}$ Conforme estudo sobre os limites subjetivos, tópico LIMITES, p. 128.

${ }^{496}$ Como dispõe o artigo 13 e 14 do regimento interno do PI447: “Art. 13. No que tange à legitimidade para o pedido de indenização por danos materiais, esta será considerada automática apenas em relação (i) aos cônjuges, (ii) companheiros(as) das vítimas que, nesta última hipótese, assim comprovarem referida condição, apresentando, no mínimo, três dos documentos constantes no Anexo 06 e (iii) descendentes das vítimas, com até 25 anos de idade na data do acidente. Parágrafo Único - Qualquer outra pessoa não incluída
} 
Aos outros pleiteantes, caberia provar sua qualidade de beneficiário. Os sistemas ainda previam a possibilidade de consulta às autoridades públicas integrantes do mecanismo nas hipóteses de duvida técnico-jurídicas referentes à legitimidade. ${ }^{497}$

O PI447 apresenta uma peculiaridade quanto à legitimidade. Pelo acidente ter ocorrido em um voo internacional, havia a expressa menção de que estrangeiros residentes no Brasil também podiam pleitear suas indenizações por meio do programa. ${ }^{498}$

Outra característica relevante que deve ser considerada para o desenho do sistema são os vetores econômicos. Em especial, deve-se considerar que "muitos não só perderam o cônjuge, companheiro(a), filho(a), pai, mãe ou irmã(o), mas também aquele que lhes garantia o sustento material". ${ }^{499}$ Algumas vítimas eram arrimos de família, deixando dependentes desprovidos de assistência.

A demora e as necessidades financeiras tende a pressionar os beneficiários, influenciando-os a adotar um comportamento ou tomar decisões inadequadas ou com menor grau de adequação.

Como instrumento para mitigar tais questões e permitir que o legitimado pudesse participar de forma menos conturbada do processamento do conflito, havia a antecipação de determinadas quantias, como às referentes ao seguro obrigatório R.E.T.A. ${ }^{500}$

Chega-se à delicada questão da indenização da vida: quanto vale uma vida? Como indenizar familiares e outros beneficiários pelo óbito? Como calcular e negociar este

na hipótese deste artigo não terá legitimidade automática para pleitear indenização por danos materiais, devendo o grau de dependência ser previamente comprovado". "Art. 14. No que se refere à legitimidade para o pedido de indenização por danos morais, esta será considerada automática em relação aos núcleos central (pais, filhos, cônjuges e companheiros que comprovarem sua condição na forma do artigo 13) e colateral (irmão) da vítima”. Regimento Interno - Programa de Indenização Voo 447, 2009, p. 9.

497 Conforma artigos 29 e 44 da CI3054 e PI447 respectivamente. Regimento Interno - Câmara de Indenização Voo 3054, p. 17, e Regimento Interno - Programa de Indenização Voo 447, 2009, p. 20.

498 Conforme "Art. 12. Todos aqueles brasileiros e estrangeiros residentes no Brasil que sofreram danos indenizáveis ainda não reparados, relacionados às vítimas fatais do Voo 447, têm legitimidade para participar do PI 447”. Regimento Interno - Programa de Indenização Voo 447, 2009, p. 9.

${ }^{499}$ Balanço de atividades - Câmara de Indenização Voo 3054, 2009, p. 4.

500 O RETA (Responsabilidade Civil de Explorador ou Transportador Aéreo) é o seguro obrigatório para cobrir eventuais danos decorrentes do transporte aéreo. Mais informações estão disponíveis no site da Agência Nacional de Aviação Civil (ANAC): http://www2.anac.gov.br/aeronaves/rab1.asp 
valor? Como não barganhar? Como lidar com as, muitas vezes, irreais expectativas por grandes indenizações?

Nesta etapa de definição do valor a ser indenizado, a busca por informações também gera custos. Quanto uma pessoa deve receber a cunho indenizatório pelo sofrimento da perda de um familiar? Ao lado de ter que se responder a essa difícil questão, esse procedimento terá que ser feito inúmeras vezes, para os pais, filhos, irmãos, tios, uma vez que, abstratamente, o sofrimento dos diferentes membros familiares não é igual.

Como resposta a estas questões, foi utilizada a técnica dos parâmetros referenciais.

Eles são dados informativos ofertados aos sujeitos do conflito, conforme já desenvolvido em tópico específico. ${ }^{501}$ Busca-se, com eles, tanto uma redução de custo na aquisição de informações, como prover às partes elementos que possam servir como referência para a tomada de decisão.

Tanto o regimento interno da CI3054, quanto o do PI447 mencionam já em seu artigo primeiro, parágrafo único, os parâmetros referenciais. ${ }^{502}$ Posteriormente, ainda é previsto um capítulo próprio para a matéria. ${ }^{503}$

O Manual de Orientação da CI3054, por meio da resposta à pergunta "Quais são as bases de calculo da indenização?”, trazia a seguinte explanação quanto aos parâmetros referenciais: "O cálculo da indenização terá como base os parâmetros referenciais, estabelecidos com base na lei e nas decisões do Superior Tribunal de Justiça (STJ), responsável em nosso país pelas decisões de questões que envolvam a reparação de danos. Os parâmetros referenciais foram estabelecidos com base em pesquisa de julgados

\footnotetext{
${ }^{501}$ Conforme PARÂMETROS REFERENCIAIS, p. 155.

502 "Parágrafo único: os valores indenizatórios serão calculados com base nos Parâmetros Referenciais definidos a partir dos parâmetros estabelecidos pela legislação vigente e aplicados pelos tribunais pátrios". Regimento Interno - Câmara de Indenização Voo 3054, p. 6.

503 "Capítulo VII - Parâmetros Referenciais: Art. 15. Os valores das indenizações deverão ser balizados pelos Parâmetros Referenciais. $\S 1^{\circ}$. Independentemente dos Parâmetros Referenciais, sempre haverá cálculo individualizado e pormenorizado, que levará em conta as circunstâncias específicas de cada Beneficiário. $\S 2^{\circ}$. A eficácia dos Parâmetros Referenciais é exclusiva na esfera da Câmara e tem caráter extrajudicial, não vinculando as partes ao seu cumprimento fora desse âmbito. $\$ 3^{\circ}$. Os casos excepcionais serão analisados individualmente, de forma a garantir a efetiva indenização do Beneficiário”. Regimento Interno - Câmara de Indenização Voo 3054, p. 11.
} 
feita pelos órgãos que integram o Sistema Nacional de Defesa do Consumidor e foram acordados com a TAM e seguradoras para o uso exclusivo no âmbito da Câmara. A situação de cada beneficiário será avaliada individualmente, de acordo com as circunstâncias de cada caso. Os casos considerados excepcionais pela Câmara serão analisados individualmente de forma a garantir o direito à indenização efetiva. Os parâmetros referenciais somente podem ser utilizados para acordos na Câmara de Indenização. Eles não servem como prova, não vinculam a TAM e suas seguradoras, fora do âmbito da Câmara, e não se aplicam para as ações judiciais que tenham sido ou possam ser ajuizadas contra a TAM e suas seguradoras. Para resguardar a intimidade dos próprios beneficiários, o acesso aos parâmetros é restrito. Os beneficiários deverão previamente entrar em contato com a Câmara para obtê-los após o devido cadastramento".504

Do capítulo do regimento interno da CI3054 que trata dos parâmetros, destacam-se dois parágrafos, o primeiro e terceiro do artigo 15. Estes buscam nortear o funcionamento do sistema da Câmara em relação ao desafio de equilibrar a possível padronização, trazida pelos parâmetros referenciais, e a individualização, natural dos DSD.

Estes parágrafos estipulam que, independentemente dos parâmetros referenciais, haverá sempre análise individualizada e pormenorizada do caso, levando em conta circunstâncias específicas. Ainda é previsto um reforço na postura de individualização quando da existência de excepcionalidades. À luz dos princípios do direito do consumidor, há menção expressa de que se almeja, com este tratamento individualizado, garantir a efetiva indenização dos beneficiários.

Previu-se que, nas reuniões de apresentação de proposta de acordo, seria aberta oportunidade para a apresentação de eventuais circunstâncias extraordinárias, que deveriam ser consideradas para estabelecer o valor a ser indenizado. ${ }^{505}$

Os danos aos interesses individuais homogêneos, muitas vezes, dão-se de forma diluída, de modo a fazer com que seus titulares não busquem a devida tutela. Nestes

\footnotetext{
${ }^{504}$ Manual de Orientação - Câmara de Indenização Voo 3054, p. 12.

505 “art. 26 [...] Parágrafo Único. Na Reunião de apresentação da Proposta de Acordo será aberta oportunidade de discussão sobre eventual circunstância extraordinária, que deva ser considerada pela TAM para a alteração do valor da indenização, ou eventual erro na aplicação dos Parâmetros Referenciais ao cálculo da indenização". Regimento Interno - Câmara de Indenização Voo 3054, p. 17.
} 
acidentes aéreos, devido ao valor da indenização, era pouco provável que isso ocorresse. Em outras palavras, a redução dos custos proporcionada por um sistema adequado, influenciaria pouco a busca ou não das devidas indenizações.

Diferentemente dos representantes das companhias aéreas e das seguradoras que têm contato com o tema com mais frequência, é razoável que os beneficiários criassem grande expectativa em relação ao valor a ser pago. Os parâmetros referenciais, com a sua legitimação na jurisprudência, funcionaram como técnica apropriada para suprir a falta de recursos informativos. Com base nestes novos dados, os sujeitos podiam rever suas expectativas e recalcular suas decisões.

Estas disposições vão ao encontro de um sistema que visa o adequado processamento e solução de conflito, não desconsiderando especificidades, peculiaridades, nem excepcionalidades.

Todavia, os parâmetros não acabam totalmente com as dificuldades estabelecer as indenizações pelos danos patrimoniais, para o qual são necessárias a definição da renda da vítima e do grau de dependência dos beneficiários em relação a elas.

Problemáticas, como a impossibilidade de comprovação dessa renda ou dependência econômica por documentos oficiais, como a declaração do imposto de renda ou extratos bancários, levantam o questionamento quanto aos meios válidos de provar. Os regimentos não traziam especificações em relação aos meios de prova, admitindo-os de forma ampla.

Entre as características mais importantes dos conflitos analisados também está a presença do luto. Este sentimento de perda dos parentes, amigos e conhecidos das vítimas apresenta-se como um elemento maximizador. Ele tende a intensificar os sentimentos, assim como outros componentes dos interesses de cunho econômico. ${ }^{506}$

506 “Os familiares de vitimas de tais sinistros precisam não só suportar o intenso luto pela súbita perda de seus entes como também necessitam cuidar da situação patrimonial para que possam seguir adiante". TARTUCE, Fernanda. Mediação extrajudicial e indenização por acidente aéreo: relato de uma experiência brasileira. In Lex Humana, v. 4, n. 1, 2012, p. 33. 
Cabe destacar que, no caso do acidente do voo 447, não foi dada para alguns beneficiários, a oportunidade de enterrar seus familiares, devido ao fato de nem todos os corpos terem sido resgatados.

Entre as possíveis técnicas aplicáveis a essa situação encontram-se a postura assertiva e a ventilação de emoções. A primeira, que devia ser aplicada principalmente pelos observadores e assistentes, busca a resposta comportamental correspondente, na medida exata, das requisições da situação, como nos casos de exasperação de emoções. A ventilação das emoções, por sua vez, tem a finalidade de dar a oportunidade à parte de expor seus sentimentos, que podem ser validados pelos outros sujeitos, evitando, contudo, sua demasiada intensificação a níveis improdutivos.

Apesar de abstratamente as emoções terem o condão de intensificar as reações comportamentais, em concreto tende a existir variações na manifestação destes sentimentos por cada indivíduo. Com isso, é possível que existam tanto pessoas que busquem afastar seus sentimentos, tendo condutas preponderantemente racionais em relação ao procedimento, como também indivíduos que necessitarão apresentar suas emoções. É necessário que o sistema também esteja preparado para atender assertivamente, inclusive, essas inconstâncias.

Seja para eventual necessidade de superação de impasses nas tratativas consensuais, seja simplesmente para ofertar informação a um baixo custo aos participantes, os sistemas previam a consulta às autoridades públicas. ${ }^{507}$ Constituía uma análise neutra de terceiro não vinculante sobre temas específicos, como legitimidade, força probatória de documentos e omissões do regimento interno.

A depender do caso, este instrumento figurava também como um retorno às vias consensuais, conforme já analisado. ${ }^{508}$

\footnotetext{
${ }^{507}$ Conforme capítulo XIII e parte VI do capítulo XII do regimento interno da CI3054 e do PI447 respectivamente.

${ }^{508}$ Conforme tópico CONSTRUÇÃO DE RETORNOS À VIAS CONSENSUAIS (BUILD IN "LOOPBACKS" TO NEGOTIATION), p. 146.
} 
Além dos já mencionados encontros periódicos das autoridades e empresas para a readequação do sistema, havia a previsão da elaboração de relatórios pelos observadores das reuniões entre os beneficiários e os representantes das companhias aéreas. ${ }^{509}$ Trata-se da aplicação da técnica do feedback. ${ }^{510}$

Observa-se que, apesar da complexidade da questão, a parcela referente à responsabilidade em decorrência do acidente de consumo está previamente definida por lei. O Código de Defesa do Consumidor ao dispor de forma genérica adiciona a premissa de que os fornecedores devem indenizar, podem assim as tratativas seguirem quanto às questões remanescente, como a individualização dos valores indenizatórios.

Como já mencionado, devido a alguns fatores, o PI447 teve a oportunidade de aproveitar recursos informativos adquiridos ao logo do funcionamento da CI3054, diminuindo, dessa forma, tanto os custos de transação, como os de aprendizagem.

O regimento interno do PI447, apesar de conter normas semelhantes ao da CI3054, apresenta-as de forma mais detalhada, o que causa uma quantidade maior de disposições. Constata-se assim que houve a preocupação de suprir eventuais omissões ou obscuridades do regimento anterior.

Outra diferença entre os sistemas está no fato do Voo Air France 447 ser internacional. Isso restringiu os limites subjetivos do sistema, tendo em vista que apenas aproximadamente $25 \%$ das vítimas eram brasileiras.

Isso se refletiu nos números de pessoas indenizadas. Enquanto a CI3054 indenizou 207 beneficiários relativos a 45 vítimas, em um universo de 187 vítimas fatais ocupantes da aeronave, o PI447 indenizou 76 beneficiários referentes a 19 vítimas dos 58

\footnotetext{
${ }^{509}$ Conforme artigo $10^{\circ}$, parágrafo segundo, inciso III, do regimento interno da CI3054 e $9^{\circ}$, parágrafo primeiro, inciso V, do regimento interno do PI447: "III - dar assistência completa e contínua aos Beneficiários durante todo o procedimento da Câmara, esclarecendo eventuais dúvidas", e "V - Observação da aplicação do Regimento Interno: a D.A. terá o papel de monitorar a estrita observância deste Regimento Interno e reportar, por meio de relatório circunstanciado, o advento de casos omissos ou que suscitem dúvidas a respeito do atendimento pelos interessados dos princípios e regras aqui contidos, o que será submetido à discussão na reunião mensal subsequente Conselho Diretor do PI 447 (art. 11 infra)".

${ }^{510}$ Conforma analisado no tópico FEEDBACK, p. 152.
} 
brasileiros a bordo. ${ }^{511}$ Apesar da maior quantidade de indenizações da CI3054, o PI447 consegui alcançar aproximadamente um terço dos beneficiários, considerando uma estimativa com base nas vítimas.

\section{CONCLUSÃO}

A adequação é decorrência natural dos instrumentos. Isso porque é intrínseco a eles que sejam úteis a seus fins. Todavia, não basta atingir sua finalidade, é imprescindível que isto seja feito de forma efetiva, eficiente.

O processo, como instrumento que é, também deve ser adequado ao seu escopo. Assim sendo, os mecanismos de solução de conflito devem ser adequados para processar e solucionar os conflitos aos quais são aplicados. Disso, deve-se ter como resultado a pacificação social.

Mas, a realidade e seus conflitos mostram-se complexos. Por mais que se tende simplifica-los, separando seus elementos e classificando-os, dando origem a diversas áreas das ciências e suas disciplinas, ainda assim, eles preservam sua natureza e suas características.

A aplicação de instrumentos genéricos aos conflitos complexos tendem a não conseguir dar as respostas processuais adequadas o bastante para o tratamento e solução do conflito. Isso culmina na inutilidade do mecanismo.

Dessa forma, devem-se estudar os conflitos e seus mecanismos de solução sob a perspectiva dos mecanismos adequados de solução de conflito. Isto é, afasta-se a concepção de vias principais e alternativas e passa-se a observar cada porta como um potencial caminho adequado. Adequação que será avaliada em relação aos custos do

\footnotetext{
${ }^{511}$ Conforme notícia veiculada no jornal O Estado de São Paulo no dia 06 de outubro de 2011. Disponível em: http://www.estadao.com.br/noticias/nacional,dezenove-familias-de-vitimas-do-voo-447-aceitamindenizacao-da-air-france, $782160,0 . \mathrm{htm}$
} 
sistema (costs of disputing), resultantes do choque ou do funcionamento harmonioso dos aspectos do instrumento com os da situação conflituosa.

Constatou-se que por meio mistura e comutação da composição de interesses, da indicação de quem está certo com base em um conjunto de normas, da competição de força e também das vias consensuais e adjudicatórias é possível a criação de uma infinidade de sistemas.

O método do DSD, com o intuito de organizar este fenômeno e racionalizar o natural anseio humano de maximizar ganhos e reduzir perdas, baseando-se em princípios e técnicas, eleva ao máximo o ideário dos mecanismos adequados.

Paralelamente, a sociedade de massa potencializa os conflitos complexos. Os interesses individuais homogêneos e suas demandas repetitivas conseguem ser tratados por sistemas personalizados, que ofertam respostas adequadas inclusive para as relações de consumo e suas peculiaridades.

Por fim, constatou-se a aplicabilidade do método do DSD a casos reais de grande complexidade. É provável que, frente aos benefícios entregues às partes, como também para toda a sociedade, sistemas como o da Câmara de Indenização Voo 3054 e o do Programa de Indenização Voo 447 sejam, a cada dia, mais presentes. 


\section{BIBLIOGRAFIA}

ACKERMAN, Robert M. The September 11th victim compensation fund: an effective administrative response to a national tragedy. Harward Negotiation Law Review, v. 10, spring 2005.

ÁLVAREZ, Gladys S.; HIGHTON, Elena I.; JASSAN, Elías. Mediación y justicia. Buenos Aires: Depalma, 1996.

ALVES, Alaôr Caffé. Lógica: pensamento formal e argumentação, elementos para o discurso jurídico. $4^{\mathrm{a}}$ Ed. São Paulo: Quartier Latin, 2005.

AMABIS, José Mariano; MARTHO, Gilberto Rodrigues. Fundamentos da biologia moderna. $2^{\text {a }}$ Ed. São Paulo: Editora Moderna, 1997.

AXELROD, Robert. The Evolution of Cooperation. New York: Basic Books, 1984. Disponível em http://www-ee.stanford.edu/ hellman/Breakthrough/book/pdfs/axelrod.pdf.

AZEVEDO, Álvaro Villaça. Teoria Geral das Obrigações: Responsabilidade Civil. 10 ${ }^{\mathbf{a}}$ Ed. São Paulo: Editora Atlas, 2004.

AZEVEDO, Antônio Junqueira de. Negócio jurídico: existência, validade e eficácia. $4^{\mathrm{a}}$ Ed. São Paulo: Editora Saraiva, 2002.

BACELLAR, Roberto Portugal. A mediação no contexto dos modelos consensuais de resolução de conflito. In: Revista de Processo, São Paulo, n. 95, p. 122-134, jul.-set. 1999.

BARBOSA, Rui. Oração aos moços. São Paulo: Editora Martin Claret, 2004.

BARR, Nicholas. Economics of the welfare state. $5^{\text {a }}$ Ed. Oxford: Oxford University Press, 2012.

BEDAQUE, José Roberto dos Santos. Efetividade do processo e técnica processual. $3^{\mathrm{a}}$ Ed. São Paulo: Malheiros Editores, 2010. 
BOBBIO, Norberto. Teoria do ordenamento jurídico. 10ª Ed. Brasília: UNB, 1999.

CAPPELlETTI, Mauro; GARTH, Bryant. Acesso à justiça. Tradução Ellen Gracie Northfleet. Porto Alegre: Sergio Antonio Fabris Editor, 2002.

CARMONA, Carlos Alberto. Arbitragem e processo: um comentário à lei $n^{\circ}$ 9.307/96. $3^{\mathrm{a}}$ Ed. São Paulo: Editora Atlas, 2009.

CAVALIERI FILHO, Sérgio. Programa de responsabilidade civil. $4^{\mathrm{a}}$ Ed. São Paulo: Malheiros, 2003.

CAVALIERI FILHO, Sérgio. Programa de responsabilidade civil. $6^{\text {a }}$ Ed. São Paulo: Malheiros, 2005.

CINTRA, Antonio Carlos de Araújo; GRINOVER, Ada Pellegrini; DINAMARCO, Cândido Rangel. Teoria Geral do Processo. 22 ${ }^{\text {a }}$ Ed. São Paulo: Malheiros Editores, 2006.

COSTA, Susana Henriques da. A tutela do patrimônio público e da moralidade administrativa por meio da ação civil publica e da ação de improbidade administrativa. In MAZZEI, Rodrigo; NOLASCO, Rita Dias. Processo civil coletivo. $1^{\text {a }}$ Ed. São Paulo: Quartier Latin, 2005.

COSTANTINO, Cathy A.; MERCHANT, Christina Sickles. Designing conflict management systems. $1^{\text {a }}$ Ed. São Francisco: Jossey-Bass, 1996.

DEUTSCH, Morton. A resolução do conflito: processos construtivos e destrutivos. In AZEVEDO, André Gomma de (org.). Estudos em arbitragem, mediação e negociação. Vol. 3. Brasília: Brasília Jurídica, 2004.

DIAS, José de Aguiar. Da responsabilidade civil. Vol. 2. 5a Ed. Rio de Janeiro: Forense, 1979.

DIDIER JR., Fredie. Curso de direito processual civil. Vol. I. 15 a Ed. Salvador: Editora Juspodivm, 2013. 
DINAMARCO, Cândido Rangel. Das ações típicas. In Fundamentos do processo civil moderno. Tomo I, $3^{\text {a }}$ Ed. São Paulo: Malheiros, 2000.

DINAMARCO, Cândido Rangel. Instituições de direito processual civil. Vol. I. $5^{\text {a }}$ Ed. São Paulo: Malheiros Editores, 2005.

DINAMARCO, Cândido Rangel. Instituições de direito processual civil. Vol. II. 5a Ed. São Paulo: Malheiros Editores, 2005.

DINIZ, Maria Helena. Curso de direito civil brasileiro. 19ª Ed. São Paulo: Saraiva, 2005.

FALECK, Diego. Introdução ao Design de Sistemas de Disputas: Câmara de Indenização 3054. In Revista brasileira de arbitragem, Ano V, n. 23 São Paulo: IOB, 2009.

FEINBERG, Kenneth R. What is Life Worth?: The Unprecedented Effort to Compensate the Victims of 9/11. Public Affairs, 2005.

FELSTINER, William L. F.; SARAT, Austim. The emergence and transformation of disputes: naming, blaming, claiming. In Law and society review, 1980-1981, vol. 15.

FERNANDES, Rodrigo. Compromisso de ajustamento de conduta ambiental: fundamentos, natureza jurídica, limites e controle jurisdicional. Rio de Janeiro: Editora Renovar, 2008.

FERRAZ JÚNIOR, Tercio Sampaio. Introdução ao estudo do direito: técnica, decisão,

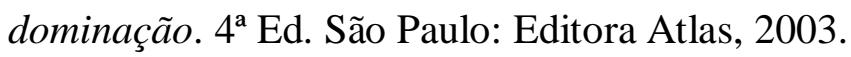

FISHER, Roger; URY, William; PATTON, Bruce. Como chegar ao sim: a negociação de acordos sem concessões. $2^{\mathrm{a}}$ Ed. Rio de Janeiro: Imago Editora, 2005.

FISS, Owen. Um novo processo civil. São Paulo: Editora revista dos tribunais, 2004.

FOLLETT, Mary Parker. Prophet of management: a celebration of writings from the 1920s. Beard Books, 1996. 
FORD, Henry. My life and work. New York: Cosimo, 2007.

FUSTIER, Michel. O conflito na empresa. São Paulo: Martins Fontes, 1982.

GALANTER, Marc. Compared to what? Assessing the quality of dispute processing. In: Denver University Law Review, n. 66, 1988-1989.

GOMES, Orlando. Contratos. 26 ${ }^{\mathrm{a}}$ Ed. Rio de Janeiro: Editora Forense, 2008.

GRINOVER, Ada Pellegrini. Da class action for damages à ação de classe brasileira: os requisitos de admissibilidade. In MILARÉ, Édis (coordenador). Ação civil pública: lei 7.347/1985 - 15 anos. $2^{\text {a }}$ Ed. São Paulo: Editora Revista dos Tribunais, 2002.

GRINOVER, Ada Pellegrini; BENJAMIN, Antonio Herman de Vasconcellos e; FINK, Daniel Roberto; FILOMENO, José Geraldo Brito; WATANABE, Kazuo; NERY JÚNIOR, Nelson; DENARI, Zelmo. Código brasileiro de defesa do consumidor: comentado pelos autores do anteprojeto. 9 $9^{\mathrm{a}}$ Ed. Rio de Janeiro: Forense Universitária, 2007.

GUERRA, Marcelo Lima. Direitos fundamentais e a proteção do credor na execução civil. São Paulo: Editora Revista dos Tribunais, 2003.

GUERRERO, Luis Fernando. Efetividade das estipulações voltadas à instituição dos meios multiportas de solução de litígios. Orientador: Prof. Associado Carlos Alberto de Salles. Tese de doutorado apresentada na Faculdade de Direito da Universidade de São Paulo. São Paulo: 2012.

LACERDA, Galeano. O código como sistema legal de adequação do processo. In: Revista do instituto dos advogados do Rio Grande do Sul. Porto Alegre, 1976.

LEE, Joel. The evolving “ $A$ ” in ADR. 14.03.2012. Disponível em Kluwer Mediation Blog: http://kluwermediationblog.com/2012/03/14/the-evolving-\%E2\%80\%9Ca\%E2\%80\%9Din-adr/.

LEONEL, Ricardo de Barros. Manual do processo coletivo. São Paulo: Editora Revista dos tribunais, 2002. 
LIEBMAN, Enrico Tullio. O despacho saneador e o julgamento do mérito. In Estudos sobre o processo civil brasileiro. $2^{\mathrm{a}}$ Ed. São Paulo: Bushatsky, 1976.

MACEDO JR., Ronaldo Porto. Contratos relacionais e defesa do consumidor. $2^{\text {a }}$ Ed. São Paulo: Revista dos Tribunais, 2006.

MANCUSO, Rodolfo de Camargo. Ação civil pública: em defesa do meio ambiente, do patrimônio cultural e dos consumidores. $12^{\mathrm{a}}$ Ed. São Paulo: Editora Revista dos Tribunais, 2011.

MARIONI, Luiz Guilherme. Novas linhas do processo civil. $3^{\text {a }}$ Ed. São Paulo: Malheiros, 1999.

MARTINS, Gilberto de Andrade. Estudo de caso: uma estratégia de pesquisa. $2^{\mathrm{a}}$ edição. São Paulo: Editora Atlas.

MAXIMIANO, Antonio Cesar Amaru. Teoria geral da administração: da revolução urbana à revolução digital. $3^{\text {a }}$ Ed. São Paulo: Editora Atlas, 2002.

MAZZILLI, Hugo Nigro. A defesa dos interesses difusos em juízo. $25^{\mathrm{a}}$ Ed. São Paulo: Editora Saraiva, 2012.

MCGOVERN, Francis E. The what and why of claims resolution facilities. Standford Law Review, Vol. 57, April 2005.

MEADOW, Carrie Menkel. Mothers and Fathers of Invention: The Intellectual Founders of ADR. Ohio: Ohio State Journal on Dispute Resolution, 2000.

MESQUITA, José Ignácio Botelho de. As novas tendências do Direito Processual: uma contribuição para seu reexame.

MORIN, Edgar. Introdução ao pensamento complexo. Tradução Eliane Lisboa. Porto Alegre: Sulina, 2006. 
NEUMANN, John von; MORGENSTERN, Oskar. Theory of Games and Economic Behavior. Princeton: Princeton University Press, 1944.

PEREIRA, Caio Mário da Silva. Instituições de direito civil: contratos, declaração unilateral de vontade, responsabilidade civil. Vol. III. 12a Ed. Rio de Janeiro: Editora Forense, 2006.

PEREIRA, Caio Mário da Silva. Instituições de Direito Civil: Introdução ao Direito Civil, Teoria Geral de Direito Civil. Vol. I. 21 a Ed. Rio de Janeiro: Editora Forense, 2005.

PEREIRA, Caio Mário da Silva. Instituições de direito civil: teoria geral das obrigações. Vol. II. 20ª Ed. Rio de Janeiro: Editora Forense, 2005.

PINHO, Rodrigo César Rebello. Apresentação. In Processo civil e interesse público: o processo como instrumento de defesa social. Org. SALLES, Carlos Alberto de. São Paulo: Editora Revista dos Tribunais, 2003.

PITTS, David. Brown contra a secretaria de educação [Brown v. board of education]: a decisão da suprema corte que transformou um país. Disponível em http://usinfo.state.gov/journals/itdhr/0999/ijdp/pitts.htm

POSNER, Richard Allen. Economic analysis of law. $8^{\text {a }}$ Ed. New York: Aspen Publishers, 2011.

RODRIGUES, Silvio. Direito Civil: Responsabilidade Civil. Vol.4. 20ª Ed. São Paulo: Saraiva, 2003.

SALLES, Carlos Alberto de. Arbitragem em contratos administrativos. $1^{\text {a }}$ Ed. Rio de Janeiro: Editora Forense, 2011.

SALLES, Carlos Alberto de. Mecanismos alternativos de solução de controvérsias e acesso à justiça: a inafastabilidade da tutela jurisdicional recolocada. In: FUX, Luiz; NERY JR., Nelson; WAMBIER, Teresa Arruda Alvim. Processo e Constituição. Estudos em homenagem ao Professor José Carlos Barbosa Moreira. São Paulo: Editora Revista dos Tribunais, 2006. 
SILVA, Érica Barbosa e. A efetividade da prestação jurisdicional civil a partir da conciliação. Orientador: Prof. Dr. Kazuo Watanabe. Tese de doutorado apresentada na Faculdade de Direito da Universidade de São Paulo. São Paulo: 2012.

TARTUCE, Fernanda. Mediação extrajudicial e indenização por acidente aéreo: relato de uma experiência brasileira. In Lex Humana, v. 4, n. 1, 2012.

TARTUCE, Fernanda. Mediação nos conflitos civis. São Paulo: Editora Método, 2008.

TARTUCE, Flávio. Direito Civil: Direitos das Obrigações e Responsabilidade Civil. Vol.2. $4^{\text {a }}$ Ed. São Paulo: Editora Método: 2009.

TARTUCE, Flávio. Manual de direito civil. $2^{\text {a }}$ Ed. São Paulo: Editora Método, 2012.

TARTUCE, Flávio. O conceito de contrato na contemporaneidade. Disponível em: http://www.flaviotartuce.adv.br/index2.php?sec=artigos\&id=48

URY, William L.; BRETT, Jeanne M.; GOLDBERG, Stephen B. Getting disputes resolved: designing systems to cut the cost of conflict. $1^{\text {a }}$ Ed. São Francisco: Jossey-Bass Publishers, 1988.

VEDANA, Vilson Marcelo Malchow. O perfil da mediação comunitária: Acesso à Justiça e o empoderamento da comunidade. In AZEVEDO, André Gomma de (org.). Estudos em arbitragem, mediação e negociação. Vol. 2. Brasília: Brasília Jurídica, 2003.

VENOSA, Sílvio de Salvo. Direito Civil: Responsabilidade Civil. Vol.4. $7^{\text {a }}$ Ed. São Paulo: Atlas, 2007.

WALD, Arnoldo. Curso de direito civil brasileiro: obrigações e contratos. São Paulo: RT, 1999.

WATANABE, Kazuo. Cultura da sentença e cultura da pacificação. In YARSHELL, Flávio Luiz; MORAES, Maurício Zanoide de (Org.). Estudos em homenagem à professora Ada Pellegrini Grinover. $1^{\text {a }}$ Ed. São Paulo: DPJ Editora, 2005. 
WEBER, Max. Economy and society. Los Angeles: University of California Press, 1978.

WILLIAMSON, Oliver Eaton. Transaction cost economics: The governance of contractual relations. Jornal of law and economics, Vol. 22, No. 2 (Oct., 1979).

ZAVASCKI, Teori Albino. Defesa de direitos coletivos e defesa coletiva de direitos. In Revista de processo, n. 78, abril-junho de 1995, ano 20. 


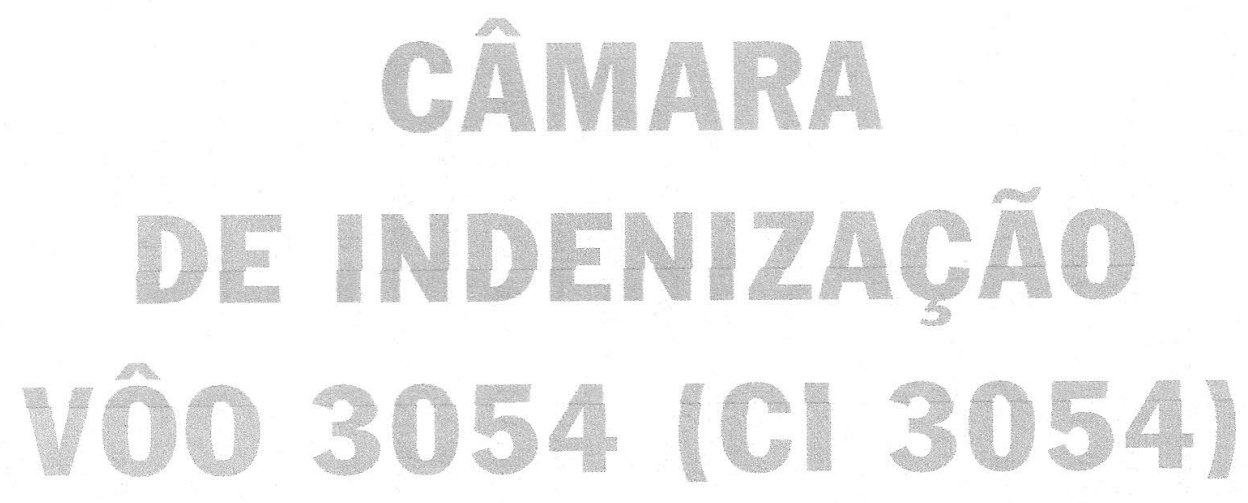

REGIMENTO INTERNO 


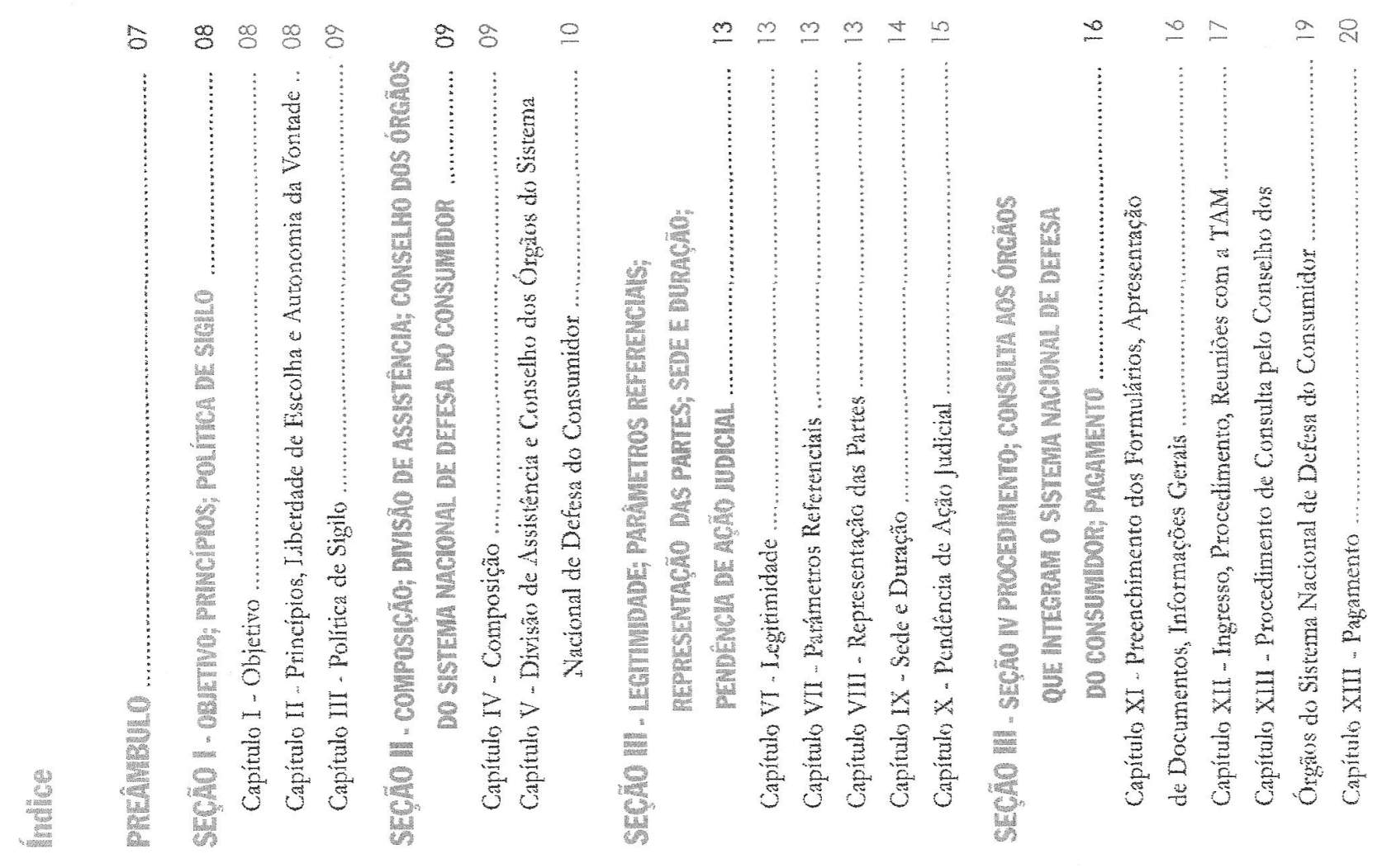




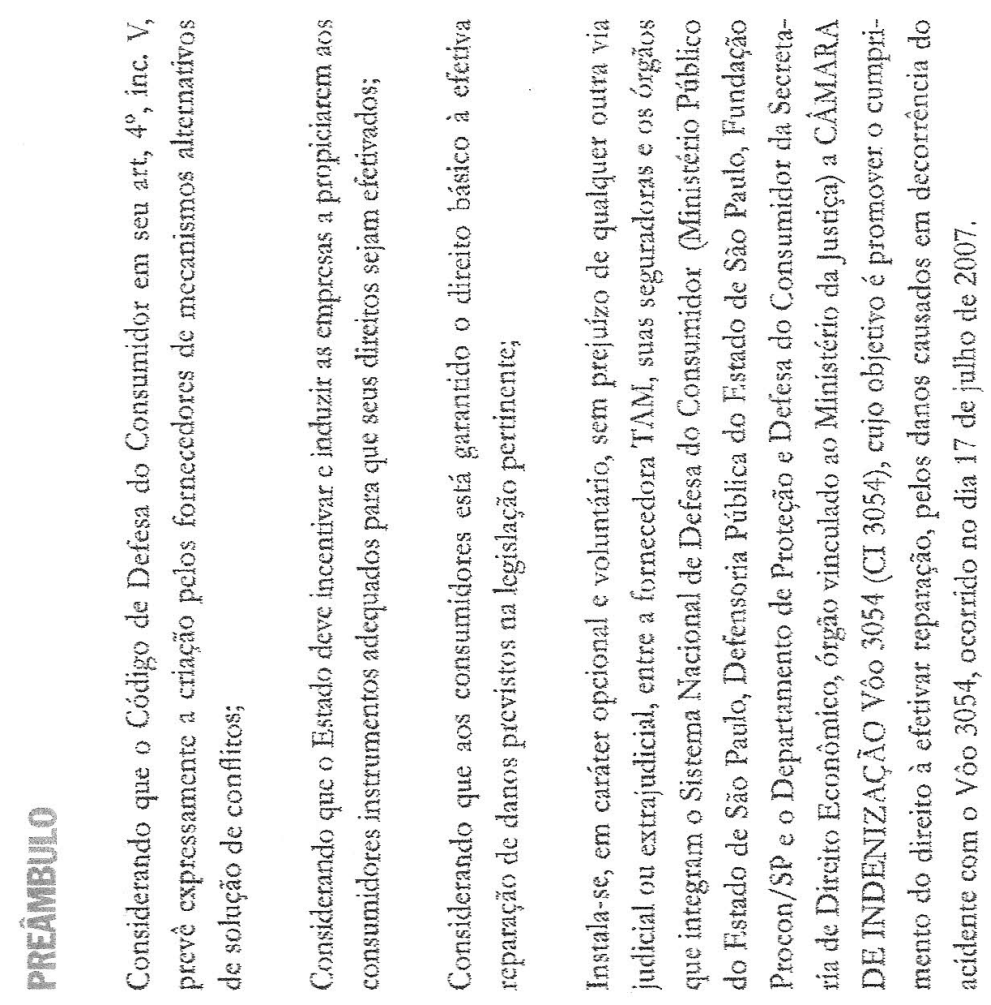




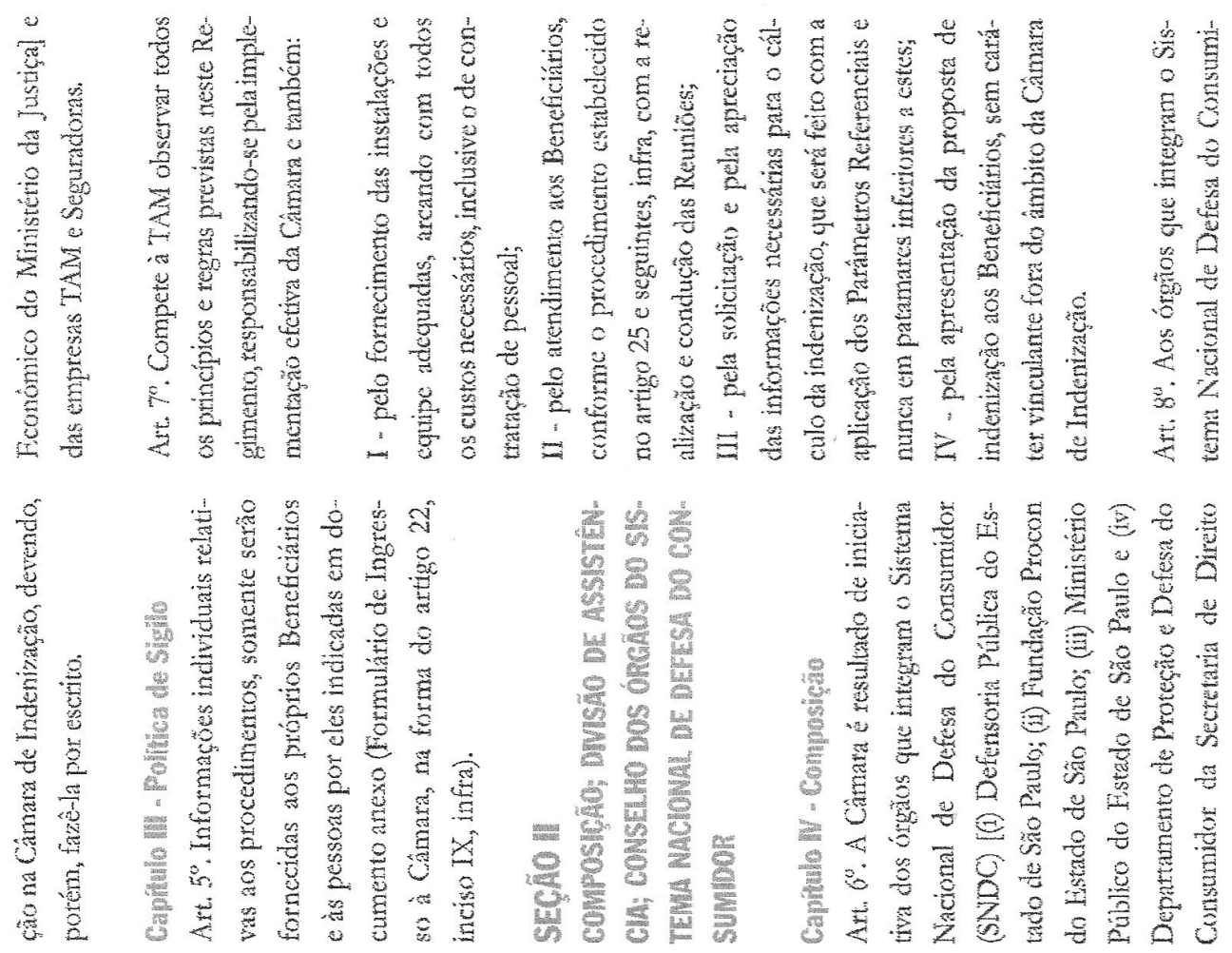

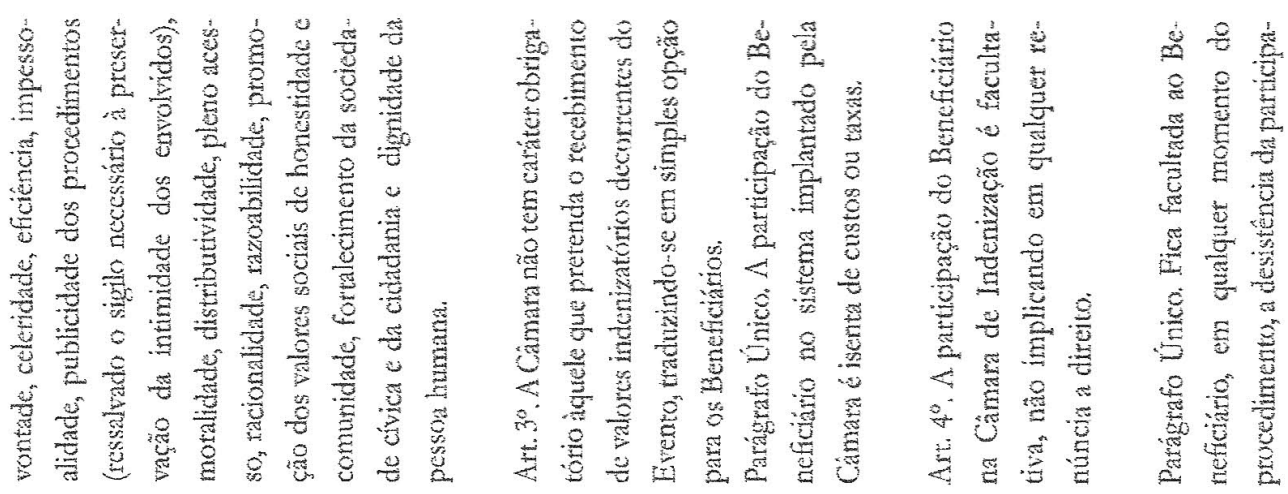

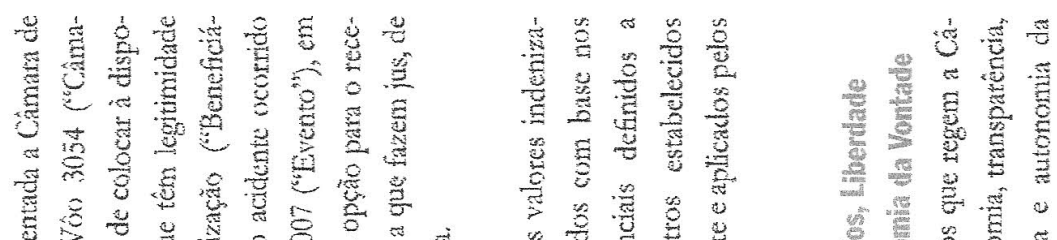

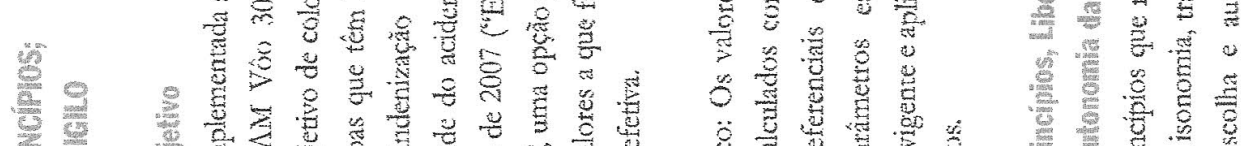

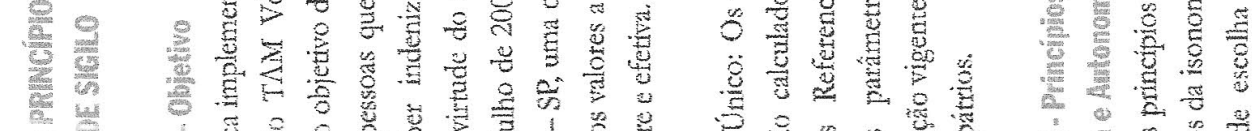

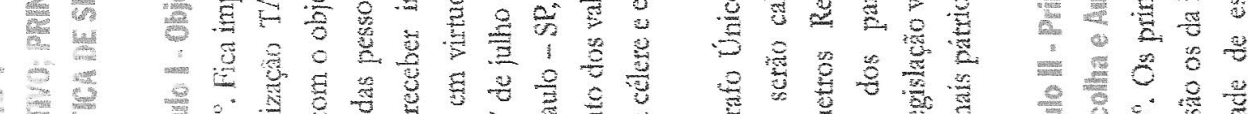

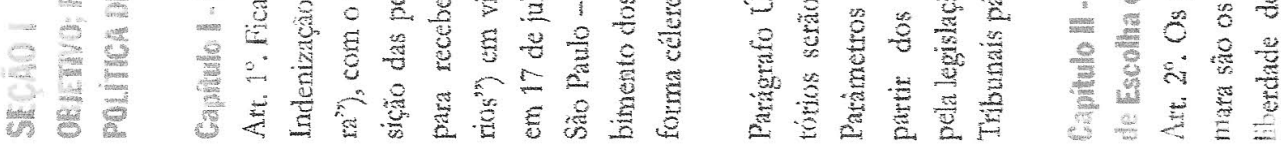




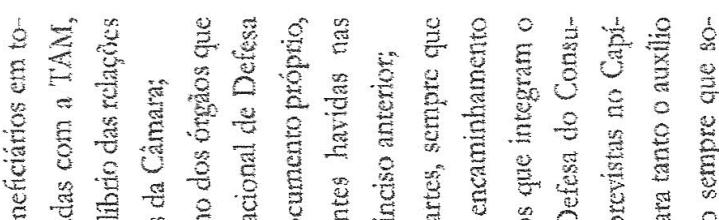
1 In In In WhInIn

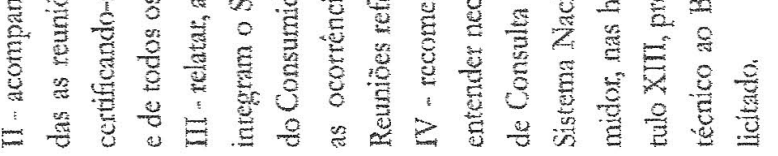

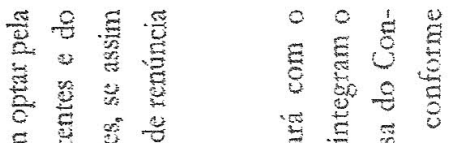

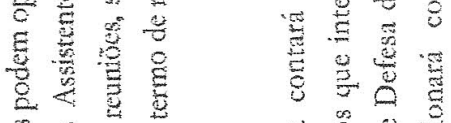

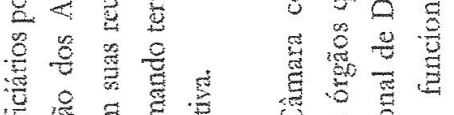

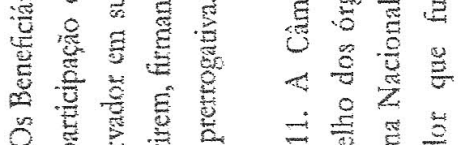

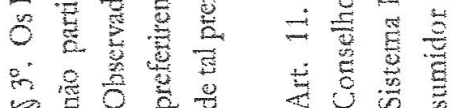

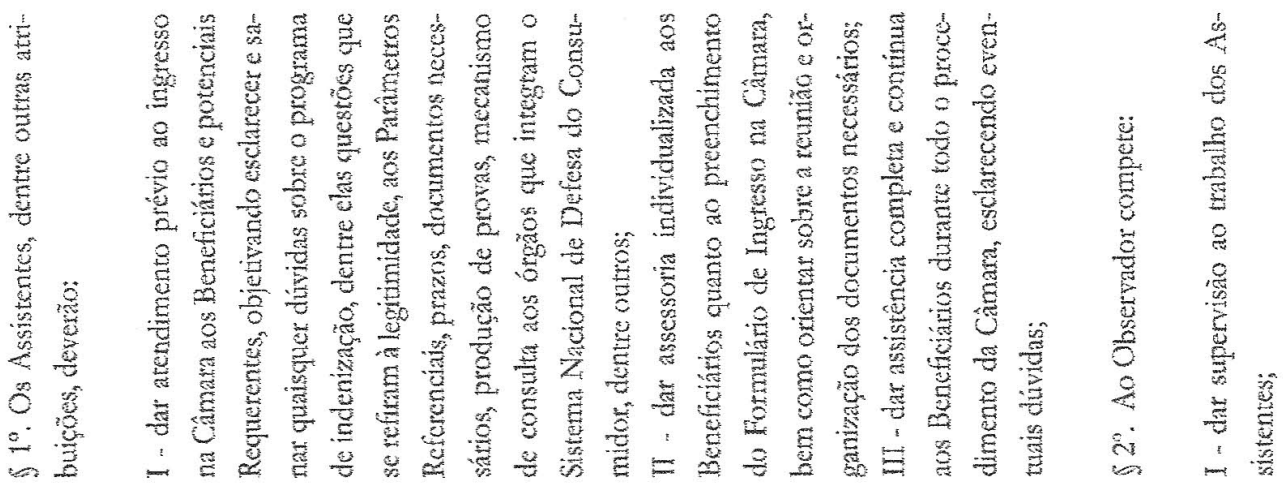

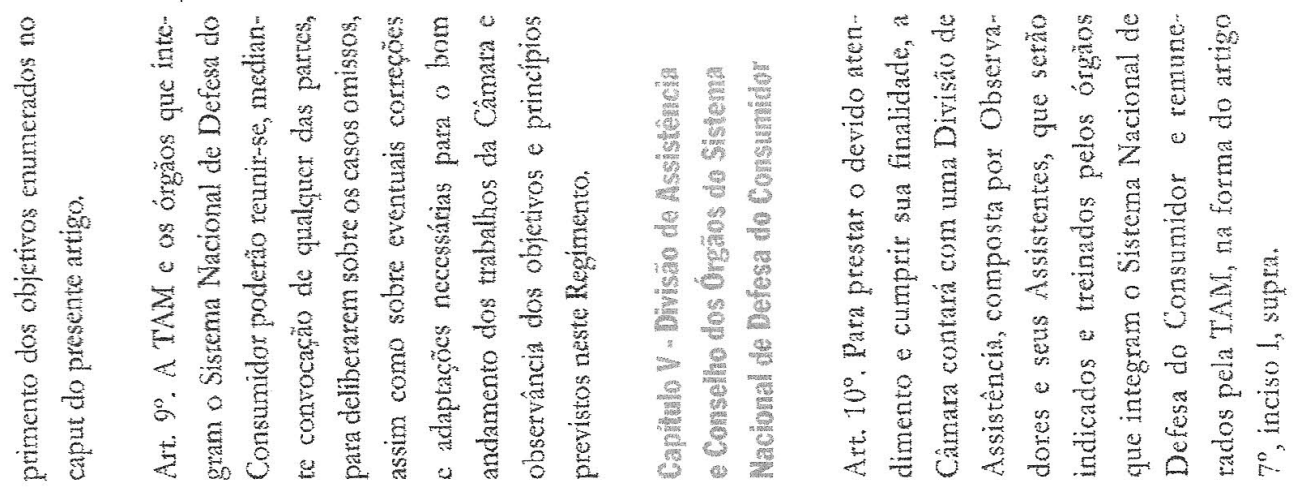

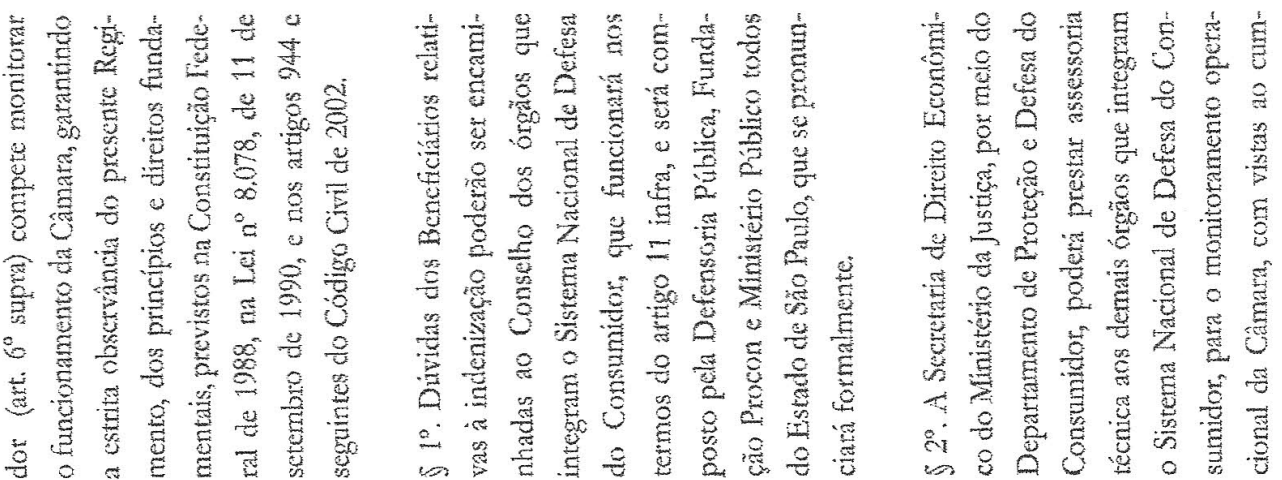

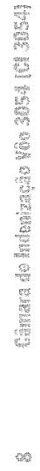



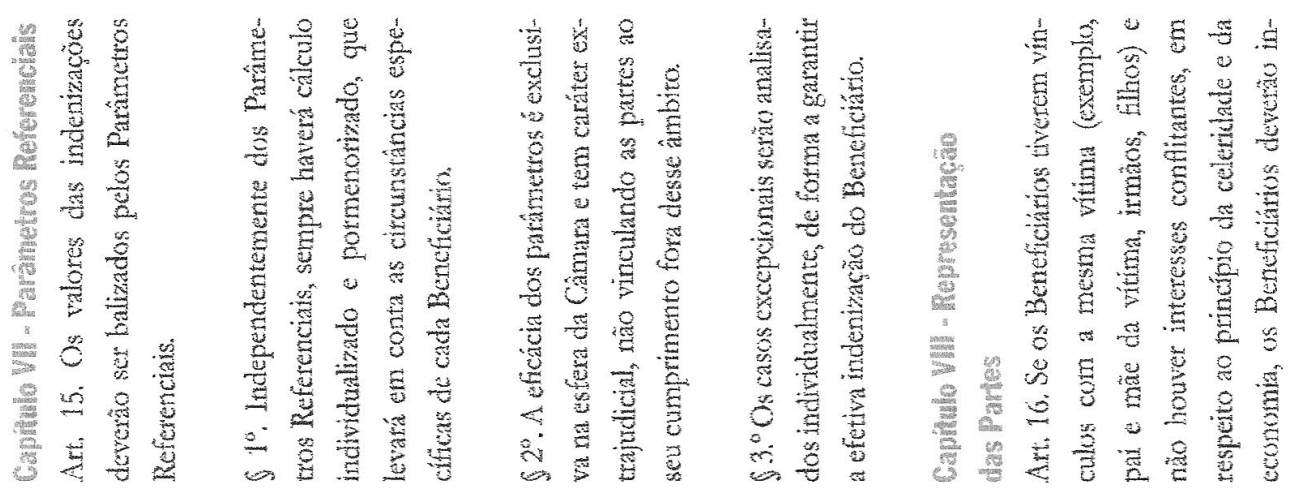

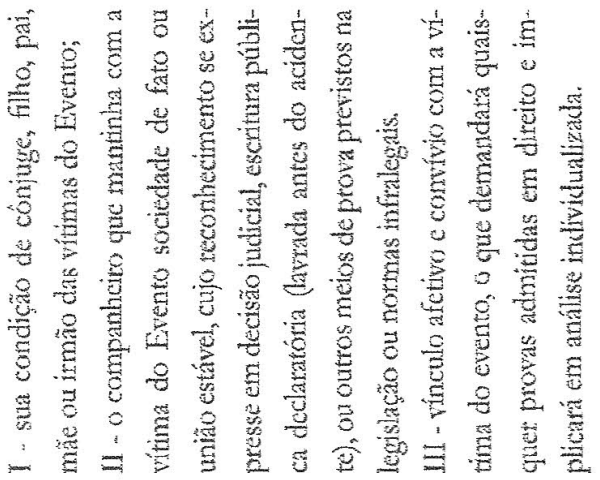

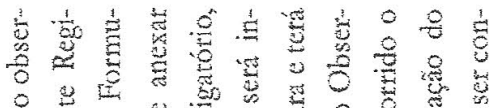

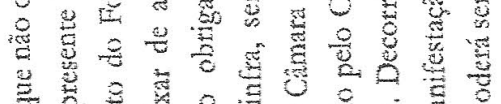

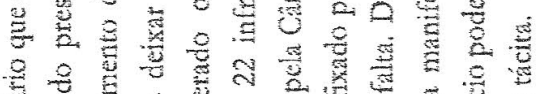

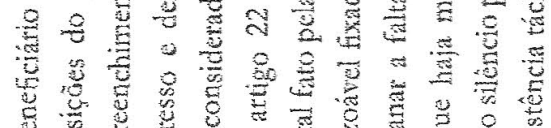

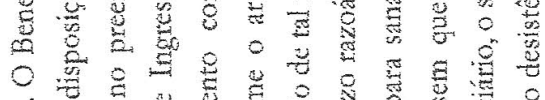

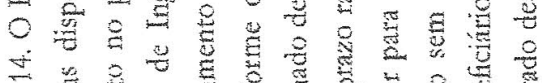

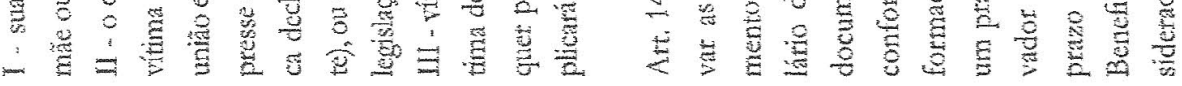

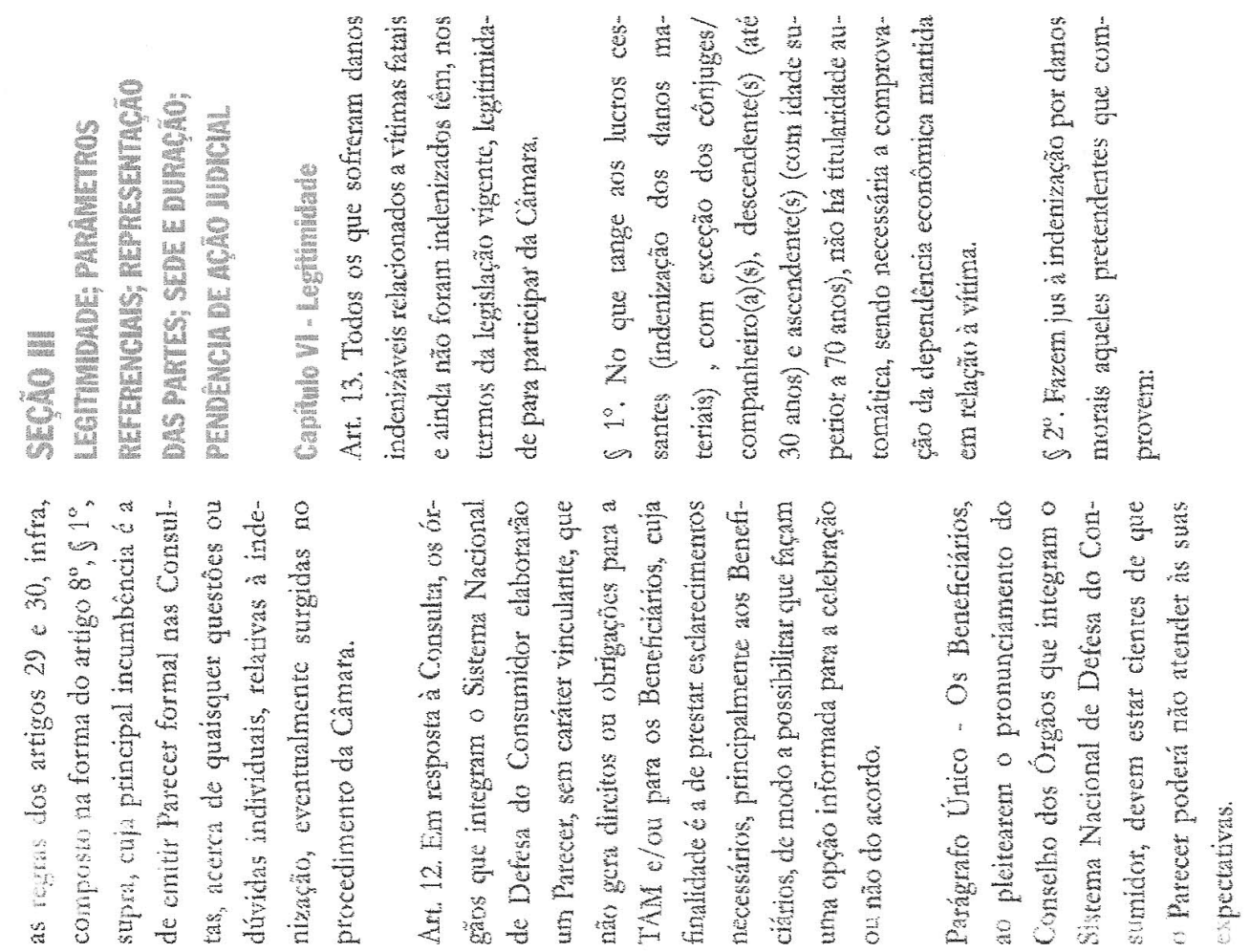



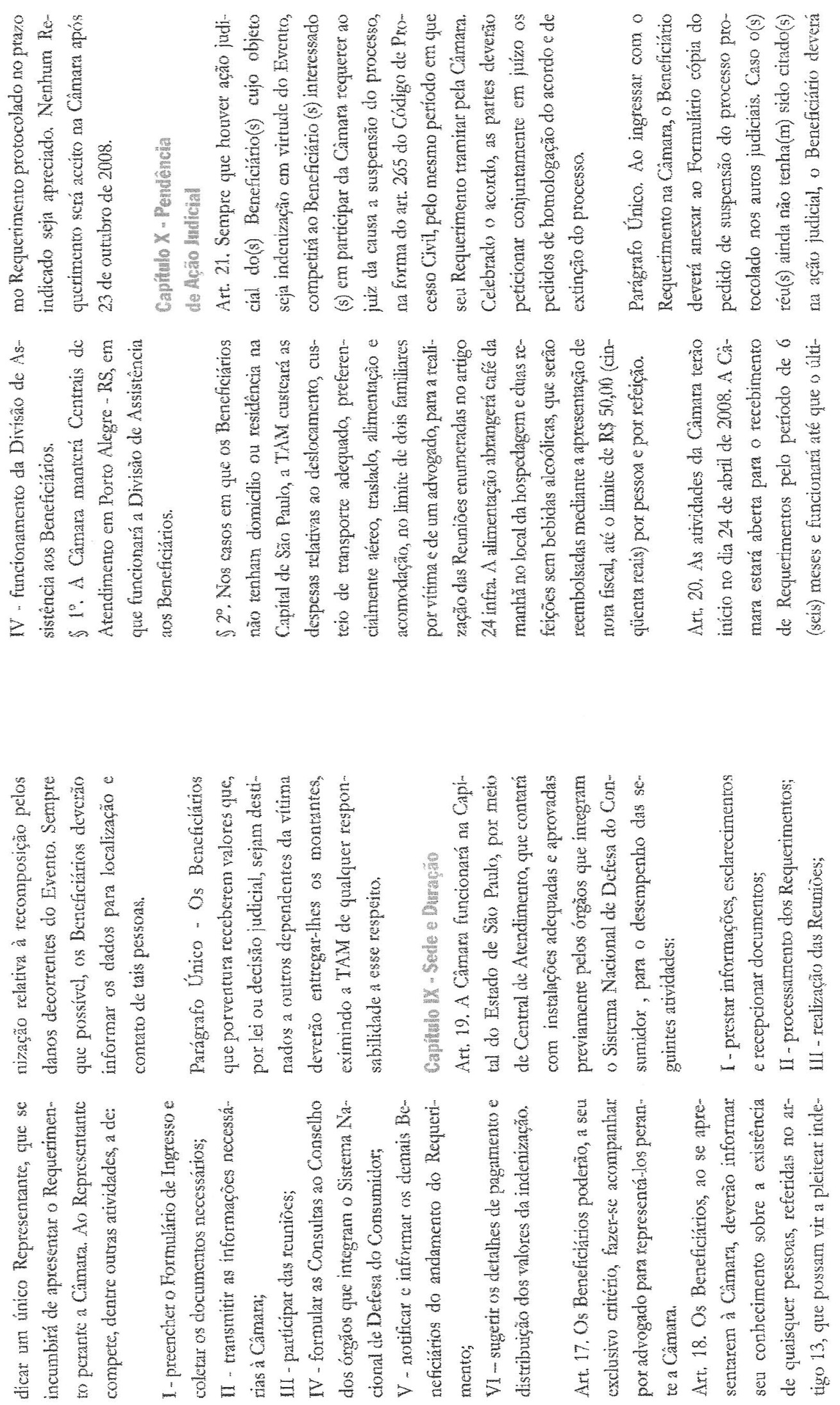

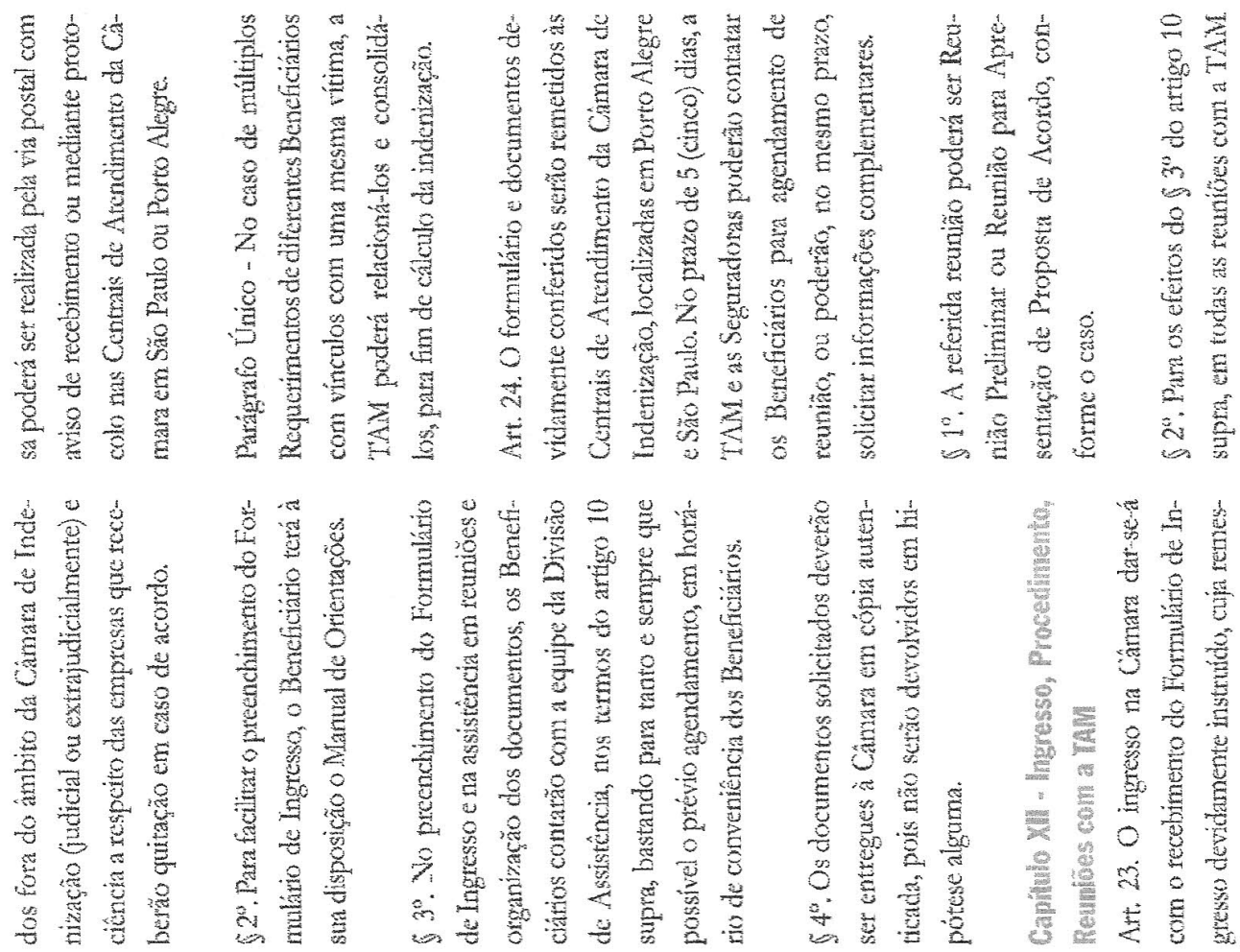

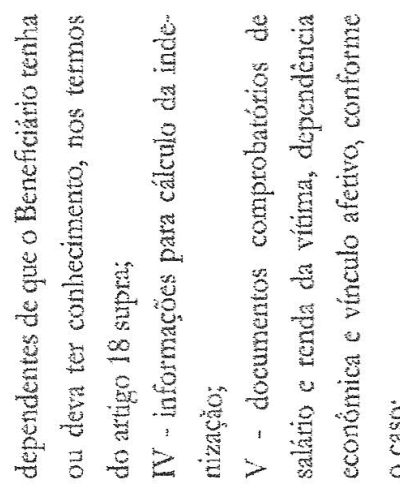

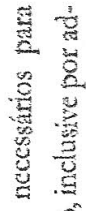

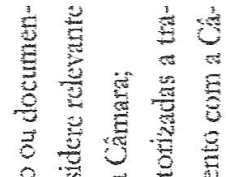

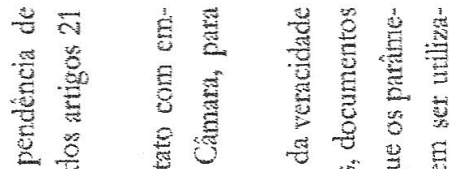
急苋氙

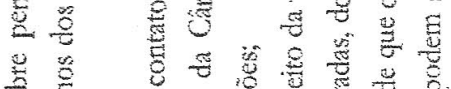

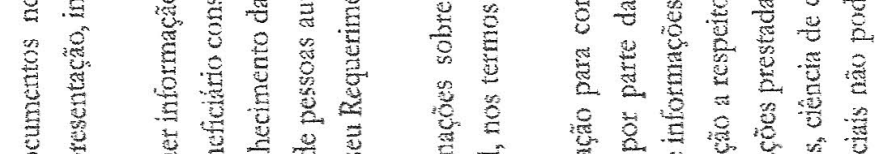

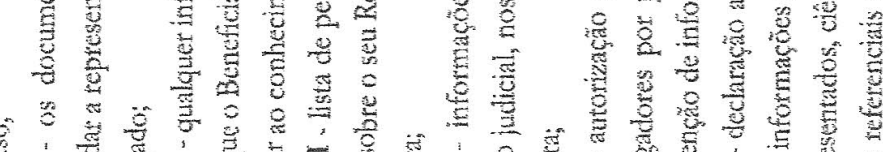

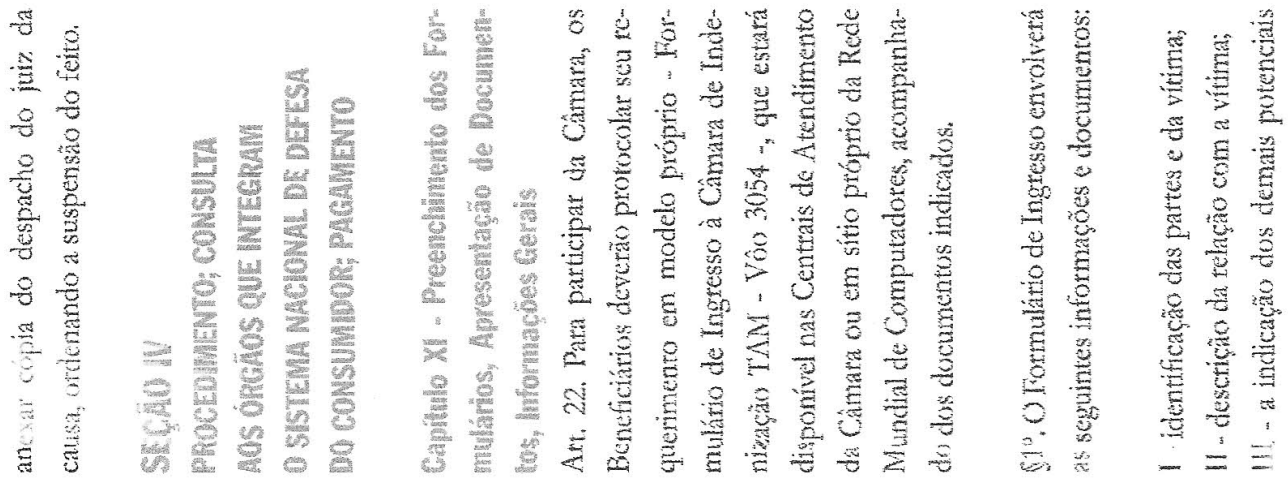



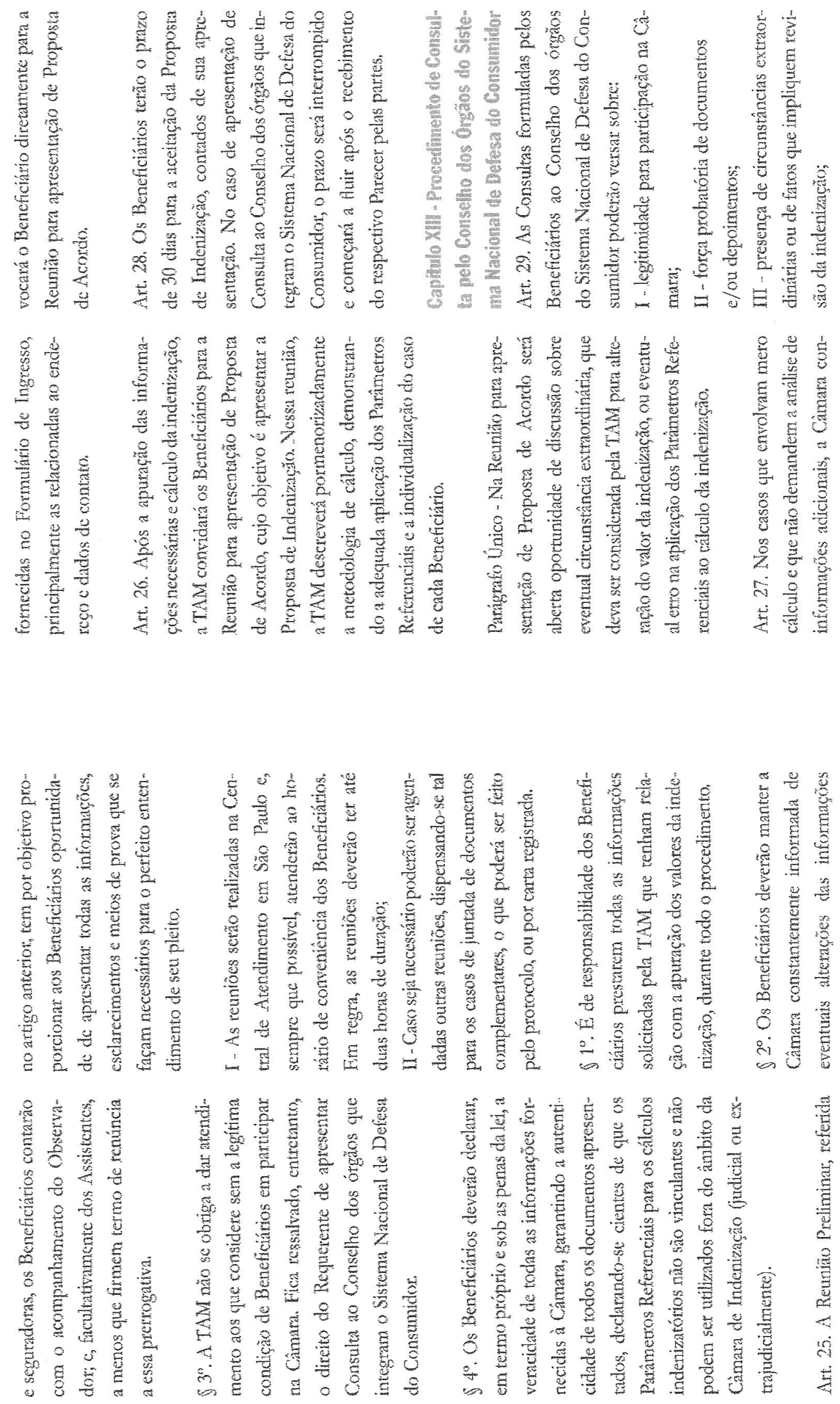

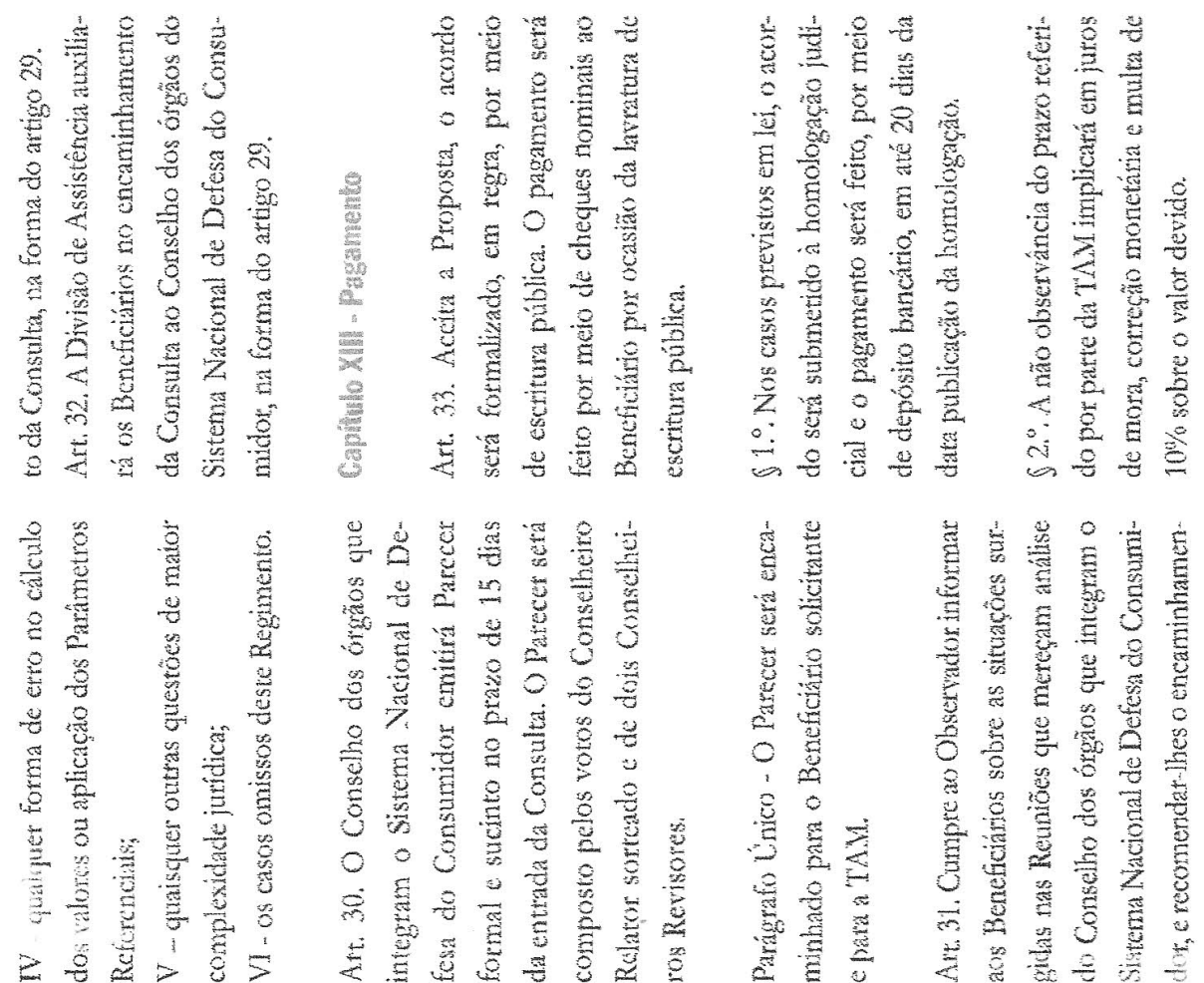

要要

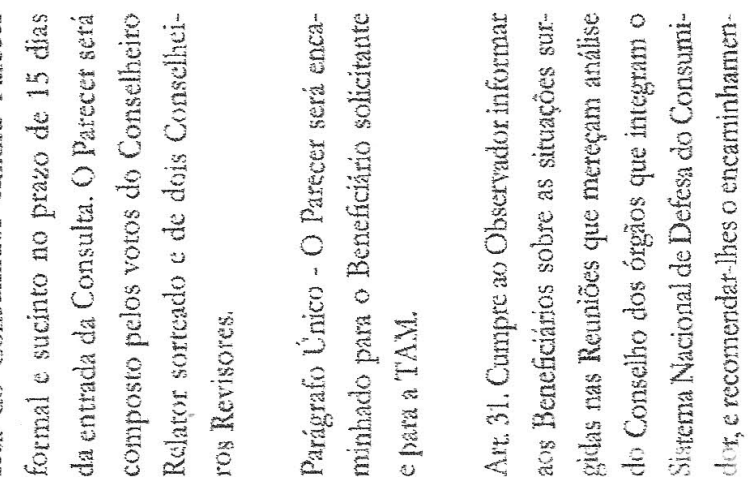




\title{
PROGRAMA DE
}

\section{INDENIZAÇÃO 447}

\author{
(PI 447)
}

REGIMENTO INTERNO 


\section{PROGRAMA DE INDENIZAÇÃO VOO 447 (PI 447) \\ REGIMENTO INTERNO}

\section{PREÂMBULO}

Considerando que o Código de Defesa do Consumidor em seu art, $4^{\mathrm{o}}$, inc. V, prevê expressamente a criação pelos fornecedores de mecanismos alternativos de solução de conflitos;

Considerando que o Estado deve incentivar e induzir as empresas a propiciarem aos consumidores instrumentos adequados para que seus direitos sejam efetivados;

Considerando que aos consumidores está garantido o direito básico à efetiva reparação de danos previstos na legislação pertinente;

Considerando os termos do Regulamento (CE) n 889/2002 do Parlamento Europeu e do Conselho da Europa de 13 de maio de 2002, bem como da Convenção de Montreal 1999, esta última recepcionada por meio do Decreto Presidencial no 5.910 de 28 de setembro de 2006;

Instala-se, em caráter opcional e voluntário, sem prejuízo de qualquer outra via judicial ou extrajudicial, o PROGRAMA DE INDENIZAÇÃO 447 ("PI 447"), cujo objetivo é promover o cumprimento do direito à efetiva reparação aos Beneficiários das vítimas pelos danos causados em decorrência do acidente com o Vôo 447 ocorrido em águas internacionais no dia 31 de maio de 2009, por volta das 23:30 (hora de Brasília) (EVENTO), estabelecido por Société AIR France (AIR FRANCE), suas seguradoras, neste ato representadas pela seguradora líder, AXA Corporate Solutions (AXA), e os seguintes órgãos que integram o Sistema Nacional de Defesa do Consumidor: Ministério Público do Estado do Rio de Janeiro (MPE/RJ) Fundação Procon/RJ (PROCON/RJ) e a Secretaria de Direito Econômico, do Ministério da Justiça (SDE/MJ) 


\title{
SEÇÃO I \\ OBJETIVO; PRINCÍPIOS; POLÍTICA DE SIGILO \\ Capítulo I - Objetivo
}

\begin{abstract}
Art. 10. Fica implementado o PROGRAMA DE INDENIZAÇÃO 447 ("PI 447" ), com o objetivo de colocar à disposição dos Beneficiários elencados no artigo 12, infra, uma opção para o recebimento dos valores a que fazem jus, de forma célere e efetiva.

Parágrafo Único - Os valores indenizatórios serão calculados com base nos Parâmetros Referenciais previamente definidos pelas entidades que compõem o PI 447, fixados a partir dos parâmetros estabelecidos pela legislação vigente e aplicados de maneira predominante pelos Tribunais pátrios.
\end{abstract}

\section{Capítulo II - Princípios, Liberdade de Escolha e Autonomia da Vontade}

Art. 20. O PI 447 é regido pelos princípios da isonomia, transparência, liberdade de escolha, autonomia da vontade, eficiência, razoabilidade, promoção dos valores sociais de honestidade e comunidade, fortalecimento da sociedade cívica e da cidadania e dignidade da pessoa humana.

Art. $3^{\text {o }}$. O PI 447 não é obrigatório e se consubstancia em opção disponível àquele que pretenda o recebimento de valores indenizatórios decorrentes do Evento.

Parágrafo Único. A participação dos Beneficiários no PI 447 é isenta de custos ou taxas.

Art. $4^{\circ}$. A participação no PI 447 é facultativa e não implica em qualquer renúncia a direitos de ambas as partes.

Parágrafo Único - Fica facultada aos Beneficiários, em qualquer momento do procedimento, a desistência da participação no PI 447, devendo, porém, fazê-la por escrito, mediante ofício dirigido aos entes que a compõem. 


\section{Capítulo III - Política de Sigilo}

Art. $5^{\mathbf{0}}$. Informações individuais relativas aos procedimentos somente serão fornecidas aos próprios Beneficiários e às pessoas por eles indicadas em documento anexo (Formulário de Ingresso no PI 447, na forma do artigo 23, infra).

\section{SEÇÃO II}

\section{COMPOSIÇÃO; DIVISÃO DE ASSISTÊNCIA; CONSELHO CONSULTIVO; CONSELHO DIRETOR}

\section{Capítulo IV - Composição}

Art. 6 ${ }^{\mathbf{0}}$. O PI 447 é resultado de iniciativa dos seguintes órgãos (i) PROCON/RJ; (ii) MPE/RJ e (iii) SDE/MJ e das empresas (iv) AIR FRANCE e (v) AXA.

Art. $7^{\mathbf{0}}$. Compete à AIR FRANCE e à AXA observar todos os princípios e regras previstas neste Regimento, responsabilizando-se pela implementação efetiva do PI 447 e também:

I - pelo fornecimento das instalações e equipe adequadas, arcando com todos os custos necessários, inclusive o de contratação de pessoal;

II - pelo atendimento aos Beneficiários, conforme o procedimento estabelecido neste Regimento, com a realização e condução das Reuniões;

III - pela solicitação e pela apreciação das informações necessárias ao demonstrativo pormenorizado da indenização, que será feito com a aplicação dos Parâmetros Referenciais;

IV - pela apresentação da proposta de indenização, quando devida, aos Beneficiários, nos moldes do Anexo 03, sem qualquer caráter vinculante fora do âmbito do PI 447.

Art. $\mathbf{8}^{\mathbf{0}}$. Aos órgãos que integram o Sistema Nacional de Defesa do Consumidor (art. $6^{\circ}$ supra) compete:

I - monitorar o andamento e zelar pelo constante aprimoramento do PI 447; 
II - supervisionar e orientar os trabalhos da Divisão de Assistência (art. $9^{\circ}$.);

III - promover o funcionamento dos mecanismos alternativos de resolução de controvérsias previstos neste Regimento (arts. $9^{\circ}$, II e IV e art. 10);

IV - garantir a estrita observância do presente Regimento, dos princípios e direitos fundamentais, previstos na Constituição Federal de 1988, na Lei nº 8.078, de 11 de setembro de 1990, nos artigos 944 e seguintes do Código Civil de 2002, no Regulamento (CE) n 889/2002 do Parlamento Europeu e do Conselho da Europa de 13 de maio de 2002 e na Convenção de Montreal 1999, esta última recepcionada por meio do Decreto Presidencial no 5.910 de 28 de setembro de 2006.

\section{Capítulo V - Divisão de Assistência; Conselho Consultivo; Conselho Diretor}

Art. 9 . Para prestar o devido atendimento e cumprir sua finalidade, o PI 447 contará com uma Divisão de Assistência (D.A.), composta por Observadores e Assistentes que serão indicados e treinados pelos órgãos que integram o Sistema Nacional de Defesa do Consumidor e remunerados pela AIR FRANCE/AXA, na forma do artigo $7^{\circ}$, inciso I, supra.

$\S 1^{\circ}$. A D.A. compreenderá as seguintes atividades:

I - Disseminação do PI 447: por meio da disponibilização e disseminação de informações a potenciais beneficiários das vítimas sobre a existência, condições e funcionamento do programa e por meio do esclarecimento de dúvidas e realização de reuniões presenciais, quando necessário.

II - Avaliação Neutra e Prévia: os Observadores e seus Assistentes, mediante solicitação de potenciais Beneficiários e independentemente do ingresso formal no PI 447, poderão analisar, na qualidade de neutros e com enfoque objetivo, os casos específicos destes, para a avaliação de alternativas e circunstâncias técnico-jurídicas, assim como a conveniência e legitimidade para o ingresso no PI 447.

III- Preparação para Ingresso no PI 447: os Observadores e Assistentes, mediante solicitação de potenciais Beneficiários, poderão assistí-los no preenchimento do Formulário de Ingresso ao PI 447 bem como orientá-los sobre a reunião e organização dos documentos que devem acompanhá-lo.

IV - Mediação: após o ingresso formal no PI 447, nas reuniões entre Beneficiários e AIR FRANCE/AXA um ou mais representantes da D.A. estarão presentes e 
funcionarão como mediadores, assistindo os interessados nas negociações, sem o poder de impor um resultado ou uma decisão a estes, com o papel de encorajar a troca de informações entre os interessados, ajudá-los a entender as perspectivas de cada uma das partes envolvidas, promover um nível produtivo de expressão emocional, ajudar as partes a avaliar realisticamente as alternativas existentes, encorajar flexibilidade, estimulr as partes à sugestão de soluções criativas para os impasses, e sugerir soluções que satisfaçam os interesses principais dos envolvidos.

V - Observação da aplicação do Regimento Interno: a D.A. terá o papel de monitorar a estrita observância deste Regimento Interno e reportar, por meio de relatório circunstanciado, o advento de casos omissos ou que suscitem dúvidas a respeito do atendimento pelos interessados dos princípios e regras aqui contidos, o que será submetido à discussão na reunião mensal subseqüente do Conselho Diretor do PI 447 (art. 11 infra).

VI - Auxílio em Consultas: assessorar os Beneficiários, nos termos do artigo 44, infra, no encaminhamento de Consulta ao Conselho Consultivo (art. 10).

VII - Organização dos trabalhos do PI 447: a D.A. terá o papel de agendar e organizar as reuniões, zelar pelo cumprimento dos prazos estabelecidos neste Regimento, bem como pelo recebimento e encaminhamento das Consultas.

$\S 2^{\circ}$. A D.A. será subordinada à SDE/MJ, que coordenará e supervisionará os seus trabalhos.

I - Os Observadores reportar-se-ão unicamente à SDE/MJ, e, por decisão monocrática deste órgão, tanto os Observadores quanto os Assistentes são demissíveis ad nutum.

II - Os Observadores coordenarão e supervisionarão os trabalhos de seus Assistentes.

$\S 3^{\circ}$. Os Beneficiários poderão optar pela não participação dos Observadores e Assistentes em suas reuniões, se assim preferirem, firmando termo de renúncia de tal prerrogativa, conforme Anexo 02.

Art. 10. Representantes do PROCON/RJ, MPE/RJ e SDE/MJ comporão o Conselho Consultivo (CC), que emitirá pareceres formais não vinculantes nos casos de Consultas formuladas pelos Beneficiários, na forma do procedimento estabelecido pelo art. 44, infra. 
Art. 11. Representantes das entidades mencionadas no art. $6^{\circ}$ supra e um representante dos familiares das vítimas, se possível, comporão o Conselho Diretor do PI 447 (CDPI). O CDPI reunir-se-á mensal, ou, no mínimo, bimestralmente, para a deliberação sobre casos gerais, particulares e omissos, assim como sobre eventuais correções e adaptações necessárias para o bom andamento do programa, com vistas ao cumprimento de seus objetivos.

Parágrafo Único - Nos casos em que forem discutidos interesses particulares dos beneficiários, a participação do representante dos familiares será dispensada para preservar a privacidade e o sigilo que norteiam o PI447, na forma do artigo $2^{\circ}$.

\section{SEÇÃO III}

\section{LEGITIMIDADE; PARÂMETROS REFERENCIAIS; REPRESENTAÇÃO DAS PARTES; SEDE E DURAÇÃO; PENDÊNCIA DE AÇÃO JUDICIAL}

\section{Capítulo VI - Legitimidade}

Art. 12. Todos aqueles brasileiros e estrangeiros residentes no Brasil que sofreram danos indenizáveis ainda não reparados, relacionados às vítimas fatais do Voo 447, têm legitimidade para participar do PI 447 (Via A - Formulário de Ingresso).

Art. 13. No que tange à legitimidade para o pedido de indenização por danos materiais, esta será considerada automática apenas em relação (i) aos cônjuges, (ii) companheiros(as) das vítimas que, nesta última hipótese, assim comprovarem referida condição, apresentando, no mínimo, três dos documentos constantes no Anexo 06 e (iii) descendentes das vítimas, com até 25 anos de idade na data do acidente.

Parágrafo Único - Qualquer outra pessoa não incluída na hipótese deste artigo não terá legitimidade automática para pleitear indenização por danos materiais, devendo o grau de dependência ser previamente comprovado.

Art. 14. No que se refere à legitimidade para o pedido de indenização por danos morais, esta será considerada automática em relação aos núcleos central (pais, filhos, cônjuges e companheiros que comprovarem sua condição na forma do artigo 13) e colateral (irmão) da vítima. 


\section{Capítulo VII - Parâmetros Referenciais}

Art. 15 Os valores das indenizações deverão ser balizados pelos Parâmetros Referenciais.

$\S 1^{\circ}$. Sempre haverá cálculo individualizado e pormenorizado no formato do Anexo 03, que levará em conta as circunstâncias específicas de cada Beneficiário.

$\S 2^{\circ}$. A eficácia dos parâmetros é exclusiva na esfera do PI 447 e tem caráter extrajudicial, não vinculando as partes ao seu cumprimento fora desse âmbito e não implicando em reconhecimento de qualquer direito.

$\S 3^{\circ}$. As propostas indenizatórias levarão em consideração a totalidade de Beneficiários da Vítima, o grau de parentesco e o respectivo grau de dependência econômica, mesmo quando um ou mais dos Beneficiários não participarem do PI 447.

$\S 4^{\text {o }}$. Todos os acordos englobarão quitação a quaisquer empresas, entes ou pessoas que possam vir a ser responsabilizadas pelo acidente, no Brasil ou no exterior.

$\S 5^{\circ}$ Os casos excepcionais serão analisados individualmente pela AIR FRANCE/AXA, na tentativa de garantir a efetiva indenização do Beneficiário.

$\S 6^{\circ}$ Os Parâmetros Referenciais NÃO serão aplicáveis aos Beneficiários ao menos que uma ou mais das condições abaixo sejam preenchidas:

(a) O país de emissão do bilhete da Air France da vítima tenha sido o Brasil;

(b) O destino final indicado no bilhete da vítima tenha sido o Brasil;

(c) O Brasil tenha sido o principal local de residência permanente da vítima.

Quando nenhuma das condições supra forem preenchidas, a indenização deverá ser calculada individualmente, levando em conta as peculiaridades de cada caso, bem como os critérios indenizatórios disponíveis em outras jurisdições competentes relacionadas a vítima em questão (Via B - Formulario de Ingresso).

\section{Capítulo VIII - Representação das Partes}

Art. 16. Se os Beneficiários tiverem vínculos familiares com a mesma Vítima e não houver interesses conflitantes, em respeito ao princípio da celeridade e da economia, os 
Beneficiários, sempre que possível, deverão indicar um único Representante, que se incumbirá de apresentar o Requerimento perante o PI 447. Ao Representante compete, dentre outras atividades, a de:

I - preencher o Formulário de Ingresso e coletar os documentos necessários;

II - transmitir aos Beneficiários as informações necessárias ao PI 447;

III - participar das reuniões;

IV - se necessário, formular Consulta ao CC;

V - notificar e informar os demais Beneficiários do andamento das tratativas;

VI - sugerir os detalhes de pagamento e distribuição dos valores da indenização.

Art. 17. Os Beneficiários poderão, a seu exclusivo critério, fazer-se acompanhar por advogado habilitado, segundo as regras vigentes para o exercício da profissão no Brasil, para representá-los perante o PI 447.

Art. 18. Os Beneficiários, ao se apresentarem ao PI 447, deverão informar seu conhecimento sobre a existência de quaisquer pessoas que possam vir a pleitear indenização relativa à recomposição pelos danos decorrentes do Evento. Sempre que possível, os Beneficiários deverão informar os dados para localização e contato de tais pessoas.

Parágrafo Único - Os Beneficiários que porventura receberem valores que, por lei ou decisão judicial, sejam destinados a outros dependentes da vítima, deverão entregar-lhes os montantes, eximindo a AIR FRANCE/AXA de qualquer responsabilidade a esse respeito, mediante declaração expressa contida no Formulário de Ingresso. 


\section{Capítulo IX - Sede e Duração}

Art. 19. O PI 447 funcionará na Capital do Estado do Rio de Janeiro, por meio do Centro de Atendimento, que contará com instalações adequadas e aprovadas previamente pelos órgãos que integram o CDPI, para o desempenho das seguintes atividades:

I - prestar informações, esclarecimentos e recepcionar documentos;

II - processamento dos Requerimentos;

III - realização das Reuniões;

IV - funcionamento da Divisão de Assistência aos Beneficiários.

Parágrafo Único - Nos casos em que os Beneficiários não tenham domicílio ou residência na Capital do Rio de Janeiro, a AIR FRANCE/AXA custearão as despesas razoáveis relativas ao deslocamento, transporte adequado, preferencialmente aéreo, traslado e acomodação (caso seja necessário o pernoite), no limite de dois familiares por vítima ou um familiar e seu advogado, para a realização das Reuniões enumeradas nos artigos 34 e seguintes.

Art. 20. As atividades do PI 447 terão início no dia 10 de dezembro de 2009. O PI 447 estará aberto para o recebimento de Requerimentos até o dia 30 de abril de 2010.

Parágrafo único: As atividades do PI447 serão interrompidas no período de 22 de dezembro de 2008 até 5 de janeiro de 2010.

\section{Capítulo X - Pendência de Ação Judicial}

Art. 21. Sempre que houver ação judicial do(s) Beneficiário(s) cujo objeto seja indenização em virtude do Evento, competirá ao Beneficiário (s) interessado (s) em participar do PI447, requerer ao juiz da causa a suspensão do processo, na forma do art. 265 do Código de Processo Civil, pelo mesmo período em que seu Requerimento tramitar pelo PI 447. Celebrado o acordo, as partes deverão peticionar conjuntamente em juízo requerendo a homologação do acordo e a extinção do processo. 
$\S 1^{\circ}$. Ao ingressar com o Requerimento no PI 447, os Beneficiários deverão anexar ao Formulário cópia do pedido de suspensão do processo protocolado na ação judicial, Caso o(s) réu(s) ainda não tenha(m) sido citado(s) na ação judicial, o Beneficiário deverá anexar cópia do despacho do juiz da causa, ordenando a suspensão do feito.

$\S 2^{\circ}$. Caso os Beneficiários possuam ação no exterior, sempre que possível aplicar-se-á os ditames do caput deste artigo. Caso a legislação do país não permita a suspensão da demanda eventualmente ajuizada, as partes envidarão esforços para encontrar uma solução conjunta, sempre objetivando a suspensão temporária da ação, enquanto durarem as tratativas de acordo no âmbito do PI 447.

$\S 3^{\circ}$. Sempre que houver ação judicial dos Beneficiários, no Brasil ou no exterior, cujo objeto seja indenização em virtude do Evento, os Beneficiários comprometer-se-ão, mediante cláusula a ser inserida no instrumento de transação, a arcar com os honorários judiciais, decorrentes da demanda supra citada, eventualmente devido as seus respectivos advogados.

$\S 4^{\circ}$. Caso os Beneficiários já tenham recebido quaisquer valores oriundos de decisões judiciais ou de outra natureza relacionados ao Evento (por exemplo: tutelas antecipadas e/ou adiantamentos), referidos montantes serão deduzidos do valor do acordo eventualmente celebrado.

\section{SEÇÃO IV}

\section{PROCEDIMENTO; CONSULTA AO CONSELHO CONSULTIVO; PAGAMENTO}

\section{Capítulo XI - Preenchimento dos Formulários, Apresentação de Documentos, Informações Gerais}

Art. 22. Para participar do PI 447, os Beneficiários deverão protocolar seu requerimento em modelo próprio - Formulário de Ingresso ao Programa de Indenização - Vôo 447, que estará disponível na Central de Atendimento e no sítio eletrônico do PI 447.

$\S 1^{\circ}$. O Formulário de Ingresso envolverá as seguintes informações e documentos:

I - identificação das partes e da vítima;

II - descrição do grau de parentesco com a vítima; 
III - a indicação dos demais potenciais dependentes de que o Beneficiário tenha ou deva ter conhecimento, nos termos do art. 18 supra;

IV - informações para cálculo da indenização;

V - documentos comprobatórios de salário e renda da vítima, dependência econômica, conforme o caso, nos termos do art. 13, supra;

VI - os documentos necessários para validar a representação, inclusive por advogado;

VII - qualquer informação ou documento que o Beneficiário considere relevante levar ao conhecimento do PI 447;

VIII - lista de pessoas autorizadas a tratar sobre o seu Requerimento com o PI 447;

IX - informações sobre pendência de ação judicial, nos termos dos art. 21 supra;

X - autorização para contato com empregadores por parte do PI 447, para obtenção de informações;

XI - declaração a respeito da veracidade das informações e documentos apresentados pelos Beneficiários;

XII - declaração de ciência e concordância aos princípios, Parâmetros Referenciais e Regulamento vigentes no âmbito do PI 447, bem como a respeito da inclusão, por parte da AIR FRANCE/AXA, das pessoas físicas e/ou jurídicas que serão elencadas na quitação em caso de acordo.

XIII - Declaração de que as Consultas e outros documentos fornecidos pelo PI 447 não têm caráter vinculante e não podem ser utilizados (judicial ou extrajudicialmente) fora deste âmbito, não implicando em reconhecimento de qualquer direito indenizatório pela AIR FRANCE/AXA.

$\S 2^{\circ}$. Para facilitar o preenchimento do Formulário de Ingresso, o Beneficiário terá à sua disposição o Manual de Orientações.

$\S 3^{\circ}$. No preenchimento do Formulário de Ingresso e na assistência em reuniões e organização dos documentos, os Beneficiários contarão com a equipe da Divisão de Assistência, nos termos do artigo $9^{\circ}$ supra, bastando para tanto e sempre que possível o prévio agendamento.

$\S 4^{\circ}$. Os documentos solicitados deverão ser entregues ao PI 447 em cópia autenticada, pois não serão devolvidos em hipótese alguma. 


\section{Capítulo XII - Procedimento, Reuniões com a AIR FRANCE/AXA}

\section{Parte I - Ingresso}

Art. 23. O ingresso no PI 447 dar-se-á com o recebimento do Formulário de Ingresso devidamente instruído, cuja remessa poderá ser realizada pela via postal com aviso de recebimento ou mediante protocolo no Centro de Atendimento no Rio de Janeiro.

Parágrafo Único - No caso de múltiplos Requerimentos de diferentes Beneficiários com vínculos com uma mesma vítima, a AIR FRANCE/AXA poderá relacioná-los e consolidá-los, para fim de cálculo da indenização, respeitados os graus de dependência econômica e de parentesco de cada Beneficiário.

Art. 24. O Beneficiário que não observar as disposições do presente Regimento no preenchimento do Formulário de Ingresso e deixar de anexar documento considerado obrigatório, conforme o artigo 23 supra, será informado de tal fato pelo PI 447 e terá um prazo razoável fixado pelo Observador para sanar a falta.

Art. 25. Os Beneficiários deverão declarar, em termo próprio e sob as penas da lei, a veracidade de todas as informações fornecidas ao PI 447, garantindo a autenticidade de todos os documentos apresentados e declarando-se cientes de que os Parâmetros Referenciais para os cálculos indenizatórios não são vinculantes e não podem ser utilizados fora do âmbito do PI 447 (judicial ou extrajudicialmente).

Art. 26. O ingresso no PI 447 implica em sujeição automática dos Beneficiários no que tange à i) outorga de quitação e exoneração de responsabilidade, em caso de acordo, em favor de todas pessoas físicas e/ou jurídicas que possam ter eventualmente contribuído para a ocorrência do EVENTO; e ii) adoção do Valor Presente Líquido (VPL) para fins de cálculo da indenização por danos materiais. 


\section{Parte II - Análise de Legitimidade}

Art. 27. Decorrido o prazo de que trata o artigo 24, com ou sem a apresentação dos documentos faltantes, o Formulário de Ingresso será remetido à AIR FRANCE/AXA para análise prévia da legitimidade dos Beneficiários.

Art. 28. Após o envio do Formulário de Ingresso, AIR FRANCE/AXA terá o prazo de 10 (dez) dias para avaliar sobre a legitimidade, total ou parcial, com relação a danos materiais ou morais, do ingresso dos Beneficiários no PI 447, e comunicará a avaliação de maneira formal, nos termos do Anexo 04.

Parágrafo Único - A AIR FRANCE/AXA poderá solicitar, conforme o caso, informações ou documentos complementares necessários para a determinação da legitimidade e/ou agendar reunião para eventuais esclarecimentos ("Reunião de Legitimidade"), o que acarretará a extensão do prazo determinado no caput, que se reiniciará e será contado da realização da reunião ou da entrega do último documento solicitado pela AIR FRANCE/AXA, o que acontecer por último.

Art. 29 Em face da decisão sobre a legitimidade dos Beneficiários contidos no Formulário de Ingresso, poderá ser apresentada uma única Consulta ao CC (art. 44 infra), que poderá versar sobre mais de um questionamento, no prazo de 10 dias contados da comunicação da decisão pela AIR FRANCE/AXA ou da Reunião de Legitimidade, o que acontecer por último.

Art. 30. Após a apresentação do Parecer pelo CC - a qual não vincula a AIR FRANCE/AXA e não tem o condão de gerar qualquer direito ou expectativa de direito aos Beneficiários - poderá a empresa reconsiderar, total ou parcialmente, por escrito, seu posicionamento inicial acerca da legitimidade dos Beneficiários.

Parágrafo Único - A comunicação dessa decisão poderá ser realizada mediante contato telefônico ou via eletrônica, com o acompanhamento do Observador, não sendo obrigatória a realização de reunião para tal fim. 
Art. 31. A decisão que considerar legítimo os Beneficiários não implica em reconhecimento, tácito ou expresso, pela AIR FRANCE/AXA, do direito de indenizar, principalmente para os fins do artigo 202 do Código Civil.

Art. 32. A AIR FRANCE/AXA não estão obrigadas a dar atendimento aos que considerem sem a legítima condição de Beneficiários em participar do Programa.

\section{Parte III - Reunião Preliminar, Reunião de Instrução, Reunião para Proposta}

Art. 33. No prazo de 10 (dez) dias úteis a partir da decisão de legitimidade, a AIR FRANCE/AXA convocará os Beneficiários para a Reunião Preliminar.

Art. 34. A Reunião Preliminar, quando necessária, será realizada uma única vez, e tem por objetivo proporcionar aos Beneficiários oportunidade de apresentar todas as informações, esclarecimentos e meios de prova que se façam necessários para o perfeito entendimento de seus pleitos e de que tratam os artigos 12, 13 e 14, supra.

Parágrafo Único - Nos casos que envolvam mero cálculo e que não demandem a análise de informações adicionais, a AIR FRANCE/AXA convocará os Beneficiários diretamente para a Reunião de Proposta (art. 42 infra).

Art. 35. A AIR FRANCE/AXA poderá solicitar, inclusive por telefone, via eletrônica e mediante acompanhamento do Observador ou Assistente, outras informações ou documentos que julgue relevante ao cálculo da indenização.

Parágrafo Único - Será atribuído prazo razoável, de comum acordo entre as partes, nunca superior a 15 dias corridos, para o fornecimento dos documentos complementares.

Art. 36. Durante o procedimento de análise, a AIR FRANCE/AXA poderá convocar as partes para realização de nova reunião ("Reunião de Instrução"), com o intuito de esclarecer questões relevantes para a análise indenizatória. 
Art. 37. As Reuniões serão realizadas no Centro de Atendimento no Rio de Janeiro no período entre 10:00 - 17:00 e, sempre que possível, atenderão ao horário de conveniência dos Beneficiários.

Art. 38. Caso seja necessário, poderão ser agendadas conferências telefônicas, dispensando-se a realização de reuniões nos casos de juntada de documentos complementares, o que poderá ser feito pelo protocolo, ou por carta registrada.

Art. 39. É de responsabilidade dos Beneficiários prestarem todas as informações solicitadas pela AIR FRANCE/AXA que tenham relação com a apuração dos valores da indenização, durante todo o procedimento.

$\S 1^{\circ}$. Os Beneficiários devem estar cientes de que o atraso ou a falta de entrega de documentos e informações por sua parte pode inviabilizar o cálculo da indenização e, que, decorridos os prazos previstos neste Regimento ou fixados com razoabilidade pelo Observador para as diligências necessárias, sem a devida providência, o PI 447 arquivará o requerimento, com a presunção de abandono ou desistência tácita por parte do Beneficiário.

$\S 2^{\circ}$. Os Beneficiários deverão manter o PI 447 constantemente informado de eventuais alterações das informações fornecidas no Formulário de Ingresso, principalmente as relacionadas ao endereço e dados de contato.

Art. 40. A AIR FRANCE/AXA deverá comunicar os Beneficiários ou seu representante, por telefone ou via eletrônica, mediante acompanhamento do Observador ou Assistente, acerca do término da análise documental, esclarecendo que a proposta será realizada com base nos documentos até então apresentados.

Parágrafo Único - Após referida comunicação, somente serão aceitos documentos novos, cuja existência não era do conhecimento prévio das partes, fato esse que deverá ser fundamentado e justificado por escrito a PI447. 


\section{V- Reunião de Proposta}

Art. 41. Para a apresentação da Proposta de Indenização, a AIR FRANCE/AXA convocará os Beneficiários para a realização de Reunião de Proposta, em que a AIR FRANCE/AXA descreverá a metodologia de cálculo utilizada, demonstrando a adequada aplicação dos Parâmetros Referenciais e a individualização do caso de cada Beneficiário.

Parágrafo Único - Na Reunião de Proposta será aberta oportunidade de discussão sobre eventuais questões/documentos que não foram considerados pela AIR FRANCE/AXA no cálculo da indenização, ou eventual erro na aplicação dos Parâmetros Referenciais ao cálculo da indenização.

Art. 42. Os Beneficiários terão o prazo de 15 (quinze) dias para a aceitação da Proposta de Indenização, contados de sua apresentação.

$\S 1^{\circ}$. A aceitação ou recusa poderá ser comunicada por qualquer meio ao Observador.

$\S 2^{\circ}$. O silêncio dos Beneficiários será interpretado como recusa à proposta formulada.

\section{Parte IV - Consultas ao Conselho Consultivo (CC)}

Art. 43. No caso do advento de dúvidas técnico-jurídicas sobre as circunstâncias consideradas para o cálculo da indenização, os Beneficiários poderão realizar uma Consulta formal ao $\mathrm{CC}$, no prazo de 5 (cinco) dias úteis contados da Reunião de Proposta, com o fim de ajudar os interessados a avaliarem melhor as circunstâncias de seus casos, eliminar expectativas não realistas e a esclarecer os limites legais que permeiam a situação, para a continuidade das tratativas, sempre que possível.

Parágrafo Único - Fica assegurado o direito da AIR FRANCE/AXA de manifestarem-se previamente à emissão do parecer pelo CC, no mesmo prazo, a contar da ciência da Consulta, que lhe será dada pelo Observador. 
Art. 44. As Consultas poderão versar sobre:

I - legitimidade para participação na Câmara;

II - força probatória de documentos e/ou depoimentos;

III - qualquer forma de erro no cálculo dos valores ou aplicação dos Parâmetros Referenciais;

IV - os casos omissos deste Regimento.

Art. 45. A Consulta será entregue pelo Beneficiário ao Observador, em via impressa ou eletrônica, que:

I - Sorteará o Relator e os dois Revisores, entre os representantes dos órgãos mencionados no art. 10 supra, e lhes encaminhará a Consulta;

II - Avisará a AIR FRANCE/AXA, por telefone ou via eletrônica, acerca do recebimento da Consulta, bem como do início do prazo de 5 (cinco) dias úteis para o oferecimento de sua Resposta.

Art. 46. Em resposta à Consulta e no prazo de 10 (dez) dias úteis contados de seu recebimento, o CC elaborará um Parecer formal e sucinto, sem qualquer caráter vinculante, que não gera direitos ou obrigações para a AIR FRANCE/AXA e/ou para os Beneficiários.

$\S 1^{\circ}$. O Parecer será encaminhado para o Beneficiário solicitante e para a AIR FRANCE/AXA.

$\S 2^{\circ}$. Os Beneficiários, ao pleitearem o pronunciamento do Conselho, devem estar cientes de que o Parecer poderá não atender às suas expectativas, não tendo ele qualquer validade fora do âmbito deste Programa.

Art. 47. A Divisão de Assistência auxiliará os Beneficiários acerca da conveniência, formulação e encaminhamento da Consulta ao CC, na forma do artigo $9^{\circ}$, supra. 


\section{$\underline{\text { Parte V - Continuidade de Tratativas }}$}

Art. 48. A Consulta interrompe o prazo para a aceitação da Proposta de Indenização, que começará a fluir após o recebimento do respectivo Parecer pelas partes, a ser enviado pelo Observador que ficará responsável pelo registro do dia e hora do recebimento.

Art. 49. Após a apresentação do Parecer pelo CC - a qual não vincula a AIR FRANCE/AXA e não tem o condão de gerar qualquer direito ou expectativa de direito aos Beneficiários - poderão a AIR FRANCE/AXA reconsiderar, total ou parcialmente, seu posicionamento inicial acerca da Proposta de Indenização.

Parágrafo Único - A comunicação dessa decisão poderá ser realizada mediante contato telefônico ou por via eletrônica, com o acompanhamento do Observador, não sendo obrigatória a realização de reunião para tal fim.

\section{Parte VI - Aceitação da Proposta e Pagamento}

Art. 50. Aceita a Proposta de Indenização as partes, dentro do prazo improrrogável de 15 (quinze dias) deverão agendar reunião (Reunião Final) para assinatura do(s) instrumento(s) de acordo(s). Nessa reunião, será obrigatório o comparecimento pessoal de todos os Beneficiários indenizados e ela se realizará no Rio de Janeiro ou no domicílio dos Beneficiários, o que se provar menos oneroso para a AIR FRANCE/AXA.

Art. 51. Aceita a Proposta de Indenização, o acordo será formalizado, em regra, por meio de escritura pública. O pagamento será feito através de deposito diretamente efetuado na conta informada pelo Beneficiário em até 15 dias após a lavratura da escritura pública, cujos custos referentes a este pagamento ficarão a cargo da AIR FRANCE/AXA.

$\S 1^{\mathrm{o}}$. Nos casos previstos em lei, mormente aqueles envolvendo menores Beneficiários, o acordo será submetido à homologação judicial e o pagamento será feito, por meio de 
depósito bancário, em até 20 dias da data publicação da homologação, contra a qual não couber qualquer recurso pelas partes e/ou pelo Ministério Público.

$\S 2^{\circ}$. A divisão dos valores indenizatórios é prerrogativa dos próprios Beneficiários.

$\S 3^{\circ}$. Quando houver interesse de menores, o Ministério Público, sem prejuízo da futura homologação judicial, será cientificado, nos termos do Anexo 05, para que se pronuncie sobre a divisão do valor pactuado, na forma sugerida pelos Beneficiários.

$\S 4^{\circ}$. A não observância, por parte da AIR FRANCE/AXA, do prazo referido no $\S 1^{\circ}$., supra, implicará em juros de mora, correção monetária e multa de $1 \%$ ao mês sobre o valor devido.

$\S 5^{\circ}$. No acordos em que seja necessária a elaboração de instrumentos distintos (homologação e escritura pública) os honorários advocatícios, em sua totalidade, serão pagos apenas quando da homologação do acordo, momento em que se encerra a prestação dos serviços advocatícios.

$\S 6^{\circ}$. Nos casos em que exista interesse de menor envolvido, a homologação do acordo contará com a participação de todos os Beneficiários que estejam sendo indenizados por danos materiais.

$\S 7$. Os Beneficiários ficam cientes de que o trâmite processual da homologação depende da atuação dos órgãos públicos competentes. 